\title{
Evaluation of Technology Modifications Required to Apply Clean Coal Technologies in Russian Utilities
}

RECEIVED

AllG 121997

OSTI

\author{
Final Report \\ December 1995
}

Work Performed Under Contract No.: DE-FG21-94MC31392

For

U.S. Department of Energy

Office of Fossil Energy

Morgantown Energy Technology Center

P.O. Box 880

Morgantown, West Virginia 26507-0880

By

All-Russian Thermal Engineering Institute

14/23 Avtozavodskaya S

Moscow 109280, Russia

DISTABUTION OF THS DOCUMEMT IS UNAMTES 


\section{Disclaimer}

This report was prepared as an account of work sponsored by an agency of the United States Government. Neither the United States Government nor any agency thereof, nor any of their employees, makes any warranty, express or implied, or assumes any legal liability or responsibility for the accuracy, completeness, or usefulness of any information, apparatus, product, or process disclosed, or represents that its use would not infringe privately owned rights. Reference herein to any specific commercial product, process, or service by trade name, trademark, manufacturer, or otherwise does not necessarily constitute or imply its endorsement, recommendation, or favoring by the United States Government or any agency thereof. The views and opinions of authors expressed herein do not necessarily state or reflect those of the United States Government or any agency thereof. 


\section{DISCLAIMER}

Portions of this document may be illegible electronic image products. Images are produced from the best available original document. 


\section{TABLE OF CONTENTS}

EXECUTIVE SUMMARY $\ldots \ldots \ldots \ldots \ldots \ldots \ldots \ldots \ldots \ldots \ldots \ldots \ldots \ldots \ldots$

1. OVERVIEW OF RUSSIAN POWER INDUSTRY $\ldots \ldots \ldots \ldots \ldots \ldots \ldots \ldots \ldots$ 1-1

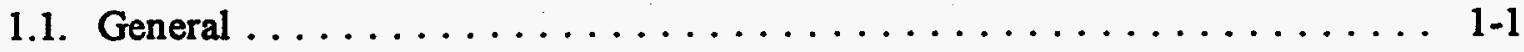

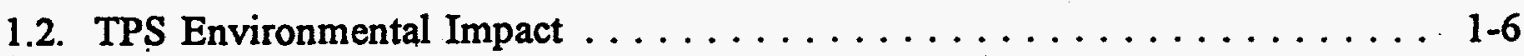

2. ELECTRIC POWER EQUIPMENT OF RUSSIA $\ldots \ldots \ldots \ldots \ldots \ldots \ldots \ldots$ 2-1

2.1. General . . . . . . . . . .

2.2. Steam Boilers and Associated Equipment $\ldots \ldots \ldots \ldots \ldots \ldots \ldots \ldots . \ldots \ldots \ldots \ldots$

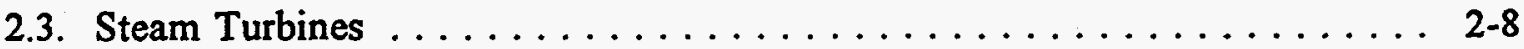

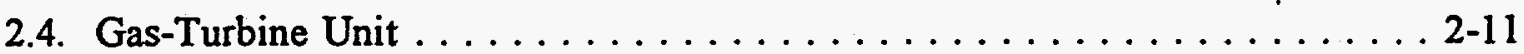

3. THE POWER INDUSTRY DEVELOPMENT FORECAST FOR RUSSIA $\ldots \ldots \ldots 3-1$

4. CLEAN COAL TECHNOLOGY DEMONSTRATION PROGRAM (CCTP) OF U.S.

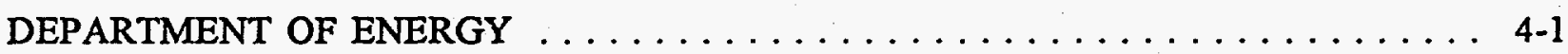

4.1. General ......................... 4-1

4.2. Project for Reducing Emissions from Conventional Boilers $\ldots \ldots \ldots$ 4-2

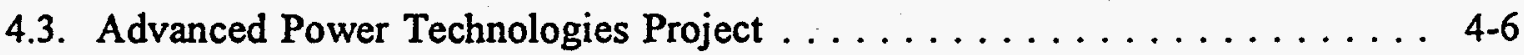

4.4. Result Obtained in CCTP Project $\ldots \ldots \ldots \ldots \ldots \ldots \ldots \ldots \ldots \ldots$ 4-12

5. REDUCTION OF COAL TPS ENVIRONMENTAL IMPACT IN RUSSIA $\ldots \ldots$. 5-1

5.1. Coal used at Russian TPS . . . . . . . . . . . . . . . . . . . . 5-1

5.1.1. General ......................... 5-1

5.1.2. Characteristics of Bituminous Coals $\ldots \ldots \ldots \ldots \ldots \ldots \ldots$ 5-2

5.1.3. Characteristics of Brown Coals ............... 5-3

5.2. Power and Environment Protection Technologies in Use . . . . . . . 5-4

6. BASE OPTIONS OF ADVANCED COAL THERMAL POWER PLANT $\ldots \ldots \ldots$ 6-1

6.1. 6.4-GW TPS Project with 800-MW, Brown K-A Coal-Fired Unit . . . . . . . 6-1

6.2. Yuzhno-Ural Ekib Bituminous Coal-fired 4-GW TPS with 500-MW Unit

Project ....................... 6-3

6.3. 2,400MW TPS with CFB Boilers Firing Poor-Quality Anthracite Culm 


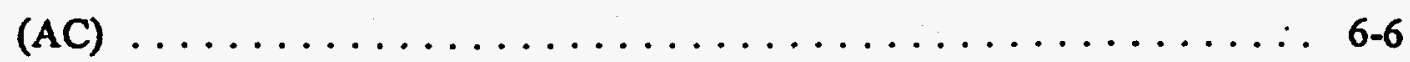

6.4. IGCC TPS Project with Entrained-Flow and Moving-Bed Coal

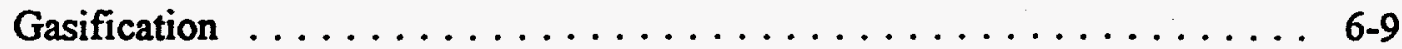

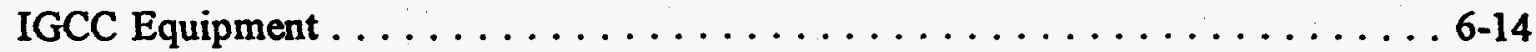

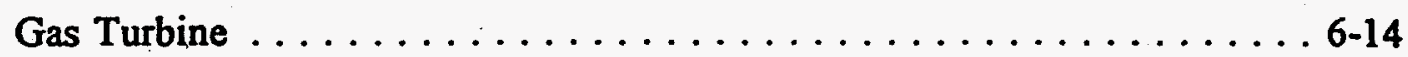

Heat-Recovery Boiler (HRSG) $\ldots \ldots \ldots \ldots \ldots \ldots \ldots \ldots \ldots \ldots 6$ 6-15

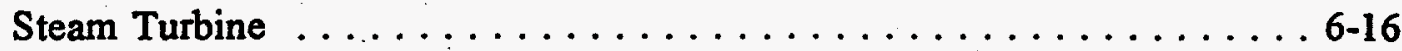

Gasifiers ........................ 6-17

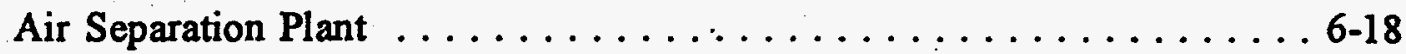

6.5. TPS with Fluidized-Bed Gasification CCP Project . . . . . . . . 6-19

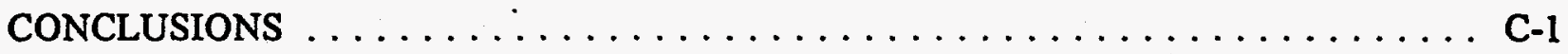

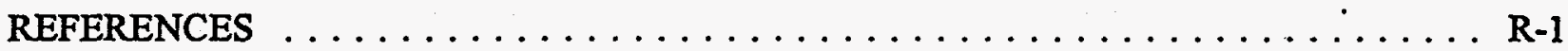

ACRONYMS AND ABBREVIATIONS $\ldots \ldots \ldots \ldots \ldots \ldots \ldots \ldots \ldots \ldots$ A-1

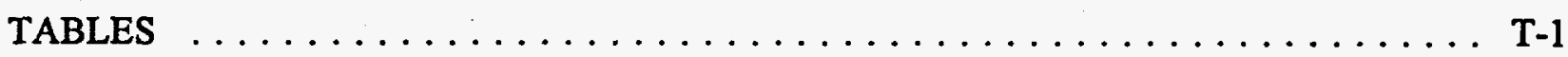

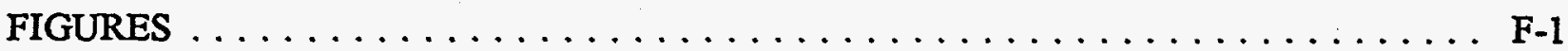




\section{EXECUTIVE SUMMARY}

The operating conditions, technology development, thermal power station (TPS) equipment, and operating and maintenance methods in Russia are very much the same as in the USA. The technical knowledge and knowhow required for designing, building, and operating an ecologically clean coal fueled TPS has been acquired at great expense over a long period of time. In many cases, the associated material and intellectual "expenditures" by Russia should be added to those expenditures in other countries. Therefore, it would be practical to use, on a mutually beneficial basis, the advanced environmental protection and energy technologies which have already been proven elsewhere, such as in the U.S.A.

Although coal is not as predominant a power industry fuel in Russia as it is the U.S.A., it plays and will continue to play in the future an important role in supplying Russian TPSs. To be competitive with natural gas, coal must be efficiently produced, transported, and fired at TPSs within permissible environmental limits.

The cheap open-cut (strip-mined) coals are located mostly in the Southern part of Central and Eastern Siberia. These regions have a high potential for further economical development. The TPSs located and constructed there largely fire local coals. The Kuznetsk bituminous and Kansk-Achinsk (K-A) brown coals are railway transported to TPSs which are thousands of $\mathrm{km}$ away from the coal production areas. An actual problem is processing these coals (especially high-moisture K-A coals) to reduce transportation costs.

Russia is very interested in the technologies developed in the U.S.A. under the Clean Coal Technology Demonstration Program (CCTP), other programs that improve existing and newly installed TPS equipment, and naturally, new advanced energy technologies that can find application at Russian TPSs.

In reconstruction and life extension of existing Russian TPSs the following technologies, particularly those developed under the CCTP, can be applied:

- primary (technological) $\mathrm{NO}_{\mathrm{x}}$ reduction methods;

- $\quad$ selective non-catalytic reduction (SNCR) of $\mathrm{NO}_{\mathbf{x}}$;

- $\quad$ simplified wet/dry de-SO ${ }_{x}$ systems.

Russia has developed it's own version of these technologies and has already implemented them at TPSs. Accordingly, in transferring U.S.A. technologies it will be necessary to 
consider the competition of domestic developers and manufacturers. It may be reasonable to combine the efforts and findings of the U.S.A. and Russia, and share in supplying the equipment required to implement the technologies in question.

Implementing a comprehensive, low-cost emission reduction technology at a Russian TPS would be of interest. For example, an installation using low- $\mathrm{NO}_{\mathrm{x}}$ burners, reburning using coal dust as a reducing agent, and non-catalytic de- $\mathrm{NO}_{x}$ sorbent injection to reduce $\mathrm{SO}_{2}$ could serve as a prototype for wide commercial implementation.

The power units (boilers) at Russian TPSs are designed for firing with both coal (fuel oil) and natural gas. Under such conditions, $\mathrm{NO}_{\mathrm{x}}$ emissions can be reduced by gas reburning. If coal or fuel oil is used for a short period of time (e.g., emergency fuel or in the coldest winter time), a simple dry de-SO $\mathrm{S}_{\mathbf{x}}$ system using Na-containing sorbents can be used to reduce $\mathrm{NO}_{\mathbf{x}}$ emissions.

For cleaning flue gases of $\mathrm{SO}_{2}$, various technologies, such as, sorbent injection into the hot duct, humidifying of gases enriched with sorbents in gas ducts, or injection of sorbent slurry into gas ducts, (Bechtel, LIMB-Coolside, $\mathrm{E}^{-S O_{x}}$, LIDS, LIFAC etc.) can find application in Russia.

Demonstration in Russia of wet/dry fluidized-bed $\mathrm{DeSO}_{x}$ technology and combined de-SO $\mathrm{S}_{\mathbf{x}}$-de-NO $\mathrm{NO}_{\mathbf{x}}$-ash removal systems based on SNRB technology is desirable. Both developments are also of interest to American companies.

The results of Russian developments of the AFBC boiler are less than those in the USA, and much less than the U.S.A. development of CCPs using PFBC and IGCC.

Participation of U.S.A. companies in the development, construction and operation of plants using the above technologies, and transfer of the U.S.A. experience to Russia is desirable.

CFB technology, including operation with high-ash coals, has been mastered in various countries on a large number of boilers. Of particular note, is the completed Nucla TPS project under the DOE CCTP.

Many existing Russian TPSs have old boilers with an input of $400-420 \mathrm{t} / \mathrm{h}$ of coal and corresponding lower output which should be considered for replacement with CFB combustion technology developed in the U.S.A. by F-W, ABB-CE, Pyropower, and B\&W. 
An important feature of these TPSs is the close location of the equipment that allows no space for installing gas cleaning systems. New CFB boilers can be adapted to the available space occupied by existing boilers of the same or lower output. Predesign (preliminary design) work done in Russia showed the B\&W technology, which requires no large external cyclones, enables the installation of CFB boilers in the existing buildings. At old TPSs difficulties may arise with the arrangement of ash collectors, such as, a high efficiency ESP.

Participation of U.S.A. companies will be required in designing the CFB boilers. Manufacture of such boilers can be arranged at Russian Works. Licensing of some components for which the U.S.A. know-how is available, or direct purchase of such components (distribution screens, instrumentation and control systems, etc.) from U.S.A. manufacturers may be needed

A question remains concerning the use in Russia of combustors designed for the DOE CCTP. According to the predesign, TRW combustors can be technically applied on Kuzn coal-fired 300-MW units, however, this application needs more information and operating experience in demo plants.

The application of CFB boilers or precombustors does not reduce the specific cost or heat consumption at a TPS. The considerable improvement to the performance will be possible by the introduction of a CCP using PFBC or integrated coal gasification.

A CCP using PFBC, like the Tidd TPS or larger, can be reasonably used in Russia to retrofit/repower an existing TPS. The small size of PFBC boiler and GT can easily be installed in the available boiler space. The steam turbine and electrical equipment can be changed a bit to increase efficiency and improve automation.

Practically all of the equipment for the first generation of PFBC plants, including the GT with an inlet temperature of about $850^{\circ} \mathrm{C}$, could be manufactured in Russia. U.S.A. engineering is necessary to design the entire plant and such equipment as furnaces (supercharged boilers), associated control systems, coal feeding, the fly ash removal before the gas turbine, HP gas/air duct with valves, etc.

Predesign work has been performed in Russia for 25-30, 80 and 270-MW CCP using a PCFB boiler design. One such project is under way as part of the CCTP (Project 7-14). It is reasonable to think of collaboration with the U.S.A. companies to develop these technical ideas. 
IGCC plants are most complex. In this field, the U.S.A. companies have the most experience and know-how. Also, the U.S.A. has produced the largest number of high-temperature GTs required for competitively efficient IGCC plants. It is desirable to construct in due time an IGCC plant in Russia that uses American experience and equipment. The ultimate choice of a technology, partners, and terms of a cooperative agreement needs special study. It should take into account the latest available results from the DOE CCTP.

IGCC plants will probably be employed at new TPSs of relatively high capacity. In-depth consideration of such TPS projects will be possible after the operability and performance of such plants is demonstrated in the U.S.A. or other countries. The conditions for the construction and successful mastering of similar domestic technologies are unrealistic in the present-day situation in Russia.

In view of the above, start-up of the first Russian IGCC plant in 10 years would be a good result. Of course, it does not mean that work under this project should be postponed. On the contrary, work should be started now, and it would be preferred to conduct projects in co-operation with foreign partners.

By participating in such projects, U.S.A. companies with their rich experience and advanced developments could become leaders, although there is little promise of a quick return on investment. It would be of advantage to organize the work dealing with these projects now, without hurry and large expenditures, with provision for speeding up after changes in the economical situation in Russia.

Russia possesses up-to-date machines and qualified specialists to produce efficient equipment for the power industry. The power industry equipment market is not mature due to the longterm existence of the monopoly of manufacturers. In recent years, the market has narrowed. At the same time, the production capabilities of manufacturers are more than enough to satisfy all possible demands. Now, Russian power equipment manufacturers have been certified by international organizations in many fields of their activity, and manufacturers cooperate with foreign partners and supply equipment aboard. With this in mind, co-operation is reasonable when the U.S.A. clean coal technologies are being transferred to Russia. Engineering by U.S.A. companies is required to design and construct dedicated equipment and systems. Equipment can be manufactured by Russian producers. The U.S.A. companies could supply some components and materials, e.g., special valves, catalysts, atomizers, I\&C equipment, etc. Of course the profit of the U.S.A. companies will not be as large as in the case of turnkey supply of complete systems. However, such cooperation is 
reasonable considering the competition of Russian and Western European companies.

In some cases, the use of ideas and developments of the Russian enterprises and specialists could improve the parameters and make some technologies more attractive for U.S.A. companies in domestic and foreign (not just Russian) marketing activitities. It may be reasonable for example, to demonstrate in Russia some technologies that are new to the U.S.A., as was done with EPA in demonstrating gas reburning at the Ladyzhinskaya TPS 300-MW unit.

Application of the U.S.A. clean coal technologies in Russia will raise the efficiency of Russian coal fired TPSs, reduce the environmental impact, and facilitate creation of a market for the know-how and equipment of U.S.A. companies. It will also ensure mutually beneficial cooperation of U.S.A. and Russian enterprises.

When transferring the technologies, it is desirable that the American side would make available:

- development of key technical solutions;

- consulting and technical supervision in designing the equipment and its installation at a TPS;

- the supply of individual types of equipment, the manufacture of which is impossible or unreasonable by Russian manufacturers;

technical supervision and management in construction, erection, adjustment and testing.

The Russian side could:

- prepare the input data for design; including siting, selection of coal and mode of operation;

- design the equipment to be manufactured in Russia and its layout at the TPS;

- conduct research to validate the design in view of the peculiarities of the fuel selected and technical selections made; 
- $\quad$ manufacture and supply equipment;

- construct and erect;

- adjust, test, and operate.

To realize each specific project it is reasonable to form a consortium of the U.S.A. and Russian enterprises including developers of the technologies and design organizations.

In the transfer of technologies the human relations, exchange of information, education and training of specialists are extremely important. Russian specialists have adequate technical knowledge and good experience. However, they are not familiar with the judicial/ legal aspects of business, and with planning and management problems.

To familiarize Russian specialists with the U.S.A. clean coal technologies it would be desirable to prepare and conduct, in Russia, a conference to present major projects or a group of projects, and, pethaps, include an exhibition of the American companies achievements.

In the field of energy generation and environmental protection many European and transnational companies have been working in Russia. Some of them have already set up joint ventures or concluded agreements with Russian producers and consumers of power industry and pollution control equipment.

Due to this fact, potential competition of Russian and European companies shall be considered in forwarding the U.S.A. technologies to the Russian market.

For the terms of application of Clean Coal Technologies at Russian TPSs see also conclusion of this study. 


\section{OVERVIEW OF RUSSIAN POWER INDUSTRY}

\subsection{General}

Russia possesses rich fuel and energy resources, however the remoteness of resources from consumers present certain problems. Thermal power stations (TPS) in Russia employ modern steam-turbine unit and operate efficiently. Construction and operation of such power stations will continue in future. Among the urgent problems are life extension and further upgrading of steam-turbine power stations, and development of combined cycle (CC) plant, the latter using first gas, and then coal [1].

The industrial and municipal electricity demands (growth) in Russia are largely met by construction of TPS. In the near future, the greater portion of electricity will be produced from natural gas and coal, mostly from natural gas.

Russian power generation is characterized by the following data (bracketed are 1990 figures when electricity generation was at the maximum level) [2].

\begin{tabular}{|l|c|c|}
\hline & 1994 & $(1990)$ \\
\hline TPS Installed capacity, GW & 210 & $(213.3)$ \\
\hline Electric generation, $\times 10^{9} \mathrm{kWh} / \mathrm{y}$ & 876.6 & $(1082.2)$ \\
\hline
\end{tabular}

Power reserve in 1994 was 15 percent on the average. Nevertheless, some regions remained energy-deficient.

Per capita electricity production was $6,190 \mathrm{kWh} / \mathrm{y}$.

The installed capacity breakdown with reference to types of power plant, are (see also Figure 1): 


\begin{tabular}{|l|c|c|}
\hline & GW & $\%$ \\
\hline Total & 210 & 100 \\
\hline Fossil-fueled, & 145.6 & 69.3 \\
\hline \multicolumn{1}{|c|}{ including } & & \\
\hline Condensing plants, & 65.6 & 31.2 \\
\hline Cogeneration plants & 80.0 & 38.1 \\
\hline Nuclear power plants (NPP) & 21.2 & 10.1 \\
\hline Hydro-power plants & 43.2 & 20.6 \\
\hline Other & 0.04 & - \\
\hline
\end{tabular}

The following thermal efficiency data are calculated using the low heating value. (LHV) of fuels; in all cases, volumes in " $\mathrm{m}^{3 \text { " }}$ are for standard conditions (if not indicated otherwise); masses (weight) are in metric t; pressure and pressure drops are in $\mathrm{Pa}, \mathrm{kPa}$, bar and $\mathrm{MPa}$

Fossil-fueled plant generated $602.8 \times 10^{9} \mathrm{kWh}$ (68.8 percent); NPP generated $97.8 \times 10^{9} \mathrm{kWh}\left(11.2\right.$ percent); and hydro-power plant generated $175.3 \times 10^{9} \mathrm{kWh}(20.0$ percent). The cogeneration plant also supplied $613.2 \times 10^{6} \mathrm{Gcal}\left(713.2 \times 10^{9} \mathrm{kWh}\right)$ of heat. Specific fuel consumption for TPS was $310.3 \mathrm{~g} / \mathrm{kWh}$ with 39.64 percent average efficiency (taking account of combined heat and power generation ).

For electric and heat generation $383.2 \times 10^{6} \mathrm{t}$ of standard fuel (tfe) was consumed. Considering a LHV of $29.3 \mathrm{MJ} / \mathrm{kg}(7,000 \mathrm{kcal} / \mathrm{kg}$ ) this includes the following fuel mix (see also Figure 2):

\begin{tabular}{|l|c|c|}
\hline Name & $10^{6} \mathrm{tfe}$ & $\%$ \\
\hline Natural gas & 244.5 & 63.8 \\
\hline Coal & 98.5 & 25.7 \\
\hline Fuel oil & 40.2 & 10.5 \\
\hline Total & 383.2 & 100.0 \\
\hline
\end{tabular}

The export of electrical energy in 1994 amounted to $21.94 \times 10^{9} \mathrm{kWh}$, which includes $1.41 \times 10^{9}$ to the Ukraine, $4.96 \times 10^{9}$ to Belorussia, $0.35 \times 10^{9}$ to the Caucasian republics, 
$7.05 \times 10^{9}$ to Kazakhstan, and $8.17 \times 10^{9}$ to Finland and other foreign countries.

The technical level of the electric power industry, and TPS in particular, is sufficiently high to provide an adequate basis for solving future technological and economical problems [3].

The electric power industry is highly centralized with over 90 percent of the generation supplied to the power grid system transmission lines at $330,500,750$ and $1150 \mathrm{kV}$.

The length of the transmission lines of all voltages classes is about $700,000 \mathrm{~km}$, and the length of lines above $110 \mathrm{kV}$ is $42,800 \mathrm{~km}$.

The generating capability is based on condensing TPS that employ 200-, 300-, 500-, and 800-MW unit, and cogeneration plant with 50-80, 100-, 180-, and 250-MW turbines. Unit larger than 250-300 MW are designed at supercritical (24 MPa) steam pressure. In general, 85 percent of the electricity is generated at TPS using high-pressure steam (13 $\mathrm{MPa})$.

Russia is located in latitudes with severe climate. Of great importance is the heating of residential, industrial, and public premises. The required heat loads and the heat and steam requirement of industrial enterprises are traditionally supplied from centralized large boiler houses and cogeneration plant. The total capacity of such plant is about $80 \mathrm{GW}$, or more then half the capacity of all TPSs. More than 80 percent of the heat supplied to consumers comes from steam extracted from steam turbines at power stations. Considering the fact that over 60 percent of the electricity in these TPS is generated in the combined mode (it is about 34 percent of the total fossil-fuel TPS generation) with an average efficiency of 46.5 percent, and a specific fuel consumption of $265 \mathrm{~g} / \mathrm{kWh}$.

Specific fuel consumption $\left(b_{e}\right)$ in the cogeneration mode is generally derived from the following expression:

$$
b_{e \cdot}=\left(Q_{t}-Q_{h}\right) /\left(N_{c} K\right)
$$

Here, $Q_{f}$ is fuel heat, $Q_{h}$ is part of fuel consumed to produce heat, $N_{c}$ is electrical output, $K$ is coefficient matching unit of measurement. The equivalent efficiency $=123 / \mathrm{b}_{\mathrm{e}}$.

The structure of fuel balances in various regions differ greatly. The larger portion of electricity in Western Siberia, the Urals, and the European part of the country is generated using natural gas. In Central and East Siberia the resources are hydro and coal, and in the 
North-West and the Far East, they are nuclear power and coal, respectively. The consumption of coal was $133.4 \times 10^{6} \mathrm{t}$ with average heating value of $16.5 \mathrm{MJ} / \mathrm{kg}$ and an ash content of 27.9 percent.

Below, are some data on coal fired condensing power unit (Figure 3):

\begin{tabular}{|c|c|c|c|c|c|}
\hline Unit capacity, MW & 800 & 500 & 300 & 200 & 150 \\
\hline Number of unit & 2 & 7 & 27 & 36 & 17 \\
\hline Average load, MW & - & 400 & 220 & 150 & 110 \\
\hline Efficiency, \%: & & & & & \\
\hline best TPS & - & 36.9 & 36.3 & 35.9 & 35.0 \\
\hline worst TPS & 33.2 & 36.2 & 30.1 & 30.4 & 34.0 \\
\hline $\begin{array}{l}\text { Share of coal in the fuel } \\
\text { consumed, \% }\end{array}$ & 97.0 & 97.7 & 77.5 & 70.0 & 70.5 \\
\hline
\end{tabular}

Coal is also fired at many cogeneration plant. It share is in these cases is $20-50$ percent. At numerous condensing and cogeneration plant coal is used as seasonal fuel.

The following condensing and big cogeneration units have been constructed and operated in Russia:

\begin{tabular}{|l|c|c|c|c|c|}
\hline Unit capacity, MW & $150-160$ & $180-220$ & $250-300$ & 500 & 800 \\
\hline Number of units & 37 & 89 & 110 & 7 & 14 \\
\hline including coal designed unit & 27 & 47 & 31 & 7 & 5 \\
\hline
\end{tabular}

Power units up to $200 \mathrm{MW}$ and equipment for cogeneration plant using 640-670 t/h boilers are designed at subcritical parameters. Condensing units at 200-215-MW and unified cogeneration units of $180 \mathrm{MW}$ are designed at $13 \mathrm{MPa}, 540 / 540{ }^{\circ} \mathrm{C}$. Cogeneration plant with smaller capacity boilers and turbines - mostly rated 60-80 and 110-115 MW - operate at $10-13 \mathrm{MPa}$, and $555^{\circ} \mathrm{C}$. Most cogeneration plant turbines extract steam for staged heating of hot water. The extraction steam pressure for that purpose ranges from 0.5-2.5 bar.

Condensing 300-, 500-, and 800-MW units and cogeneration units of $250 \mathrm{MW}$ unified with $300-\mathrm{MW}$ units are designed at supercritical steam parameters $\left(24 \mathrm{MPa}, 540 / 540^{\circ} \mathrm{C}\right.$ ). 
The total capacity of such units is about $45 \mathrm{GW}$. Their capacities and parameters are standardized. Supercritical power units with $1,000-2,650 \mathrm{t} / \mathrm{h}$ once-through boilers operate reliably and efficiently firing various fuels. The annual net efficiency of the best TPS firing gas and fuel oil is 39 percent, and in the case of coal 37 percent. The design of equipment is continuously upgraded. Four to five modifications of turbines and boilers for such units have been manufactured.

A $1,200-\mathrm{MW}$ unit has been in successful operation for over 10 years with a single-shaft, 5-cylinder (stage), 3,000-rpm turbine employing welded LP rotors and a titanium last stage with 1,200-mm long bucket. This unit, firing mostly natural gas, has operated for some (many) years practically without unscheduled shutdowns at an efficiency of 39-39.5 percent and an availability factor of over 90 percent. Based on the experience with developing, constructing and operating this turbine, LMZ has designed and supplied several 1,000-MW single-shaft turbines for NPP.

For many years (up to 1992), the Russian TPS operated at heavy-duty conditions without sufficient power reserve and had rather high reliability and availability factors. Now, under a poor economical situation, substantial reserves appeared and the utilization coefficient dropped. Consequently, the duration of repair time increased and the relability of unit and TPS was somewhat reduced.

The Russian TPS have a typical low rate of equipment renewal [4]. Currently, life expiration of the equipment is 5-7 times ahead of the addition of new capacity. As of today, about $40 \mathrm{GW}$ of TPS capacity has exceeded the design life. It is estimated that by the year 2000 this figure will increase to $90 \mathrm{GW}$. There are 20-30 unit of 150-160, 200 and $300 \mathrm{MW}$ each that have operated approximately $200,000 \mathrm{hrs}$. Some individual 150-MW unit had been in operation over $270,000 \mathrm{hrs}$. New 800 - and 1,200-MW unit have operated less than 100,000 hrs.

Many steam turbines and boilers at cogeneration plant have operated even longer than condensing unit.

Naturally, in many cases the TPS life can be extended.

Based on comprehensive research of the metal in power equipment that has seen extensive service, generalization of statistics, and durability predictions using fracture mechanics techniques, it has been established that the normal safe operation time of KhTZ 300-MW 
steam turbines is $170,000 \mathrm{hrs}$, and that of the $\mathrm{LMZ}$ steam turbines is $220,000 \mathrm{hrs}$. This is the so-called "fleet" life relating to the entire fleet of equipment.

The scope of work for inspection, repair, and replacement of key power unit component between the design life of 100,000 hrs and the fleet life does not change significantly from that required for the first $100,000 \mathrm{hrs}$.

After expiration of the fleet life one can forecast (with reference to $300-\mathrm{MW}$ unit) the following scope of work to extend it's life:

- replace 50 percent of the stop and control valves on KhTZ turbines, and 10 percent on LMZ turbines;

- $\quad$ replace 25 percent of the rotors on KhTZ and 8 percent on LMZ turbines;

- repair of 25 percent of the rotors on $\mathrm{KhTZ}$ and 10 percent on LMZ turbines;

- repair of 30 percent of KhTZ and LMZ turbine cylinder casings by grinding to remove surface cracks and/or repairing deeper cracks by metal-locking or similar techniques;

- replace about half of the live steam and hot reheat pipes (or rehabilitate by heat treatment);

- $\quad$ replace 30 percent of boiler heating surfaces.

Accomplishing the above scopes of replacement and repair followed by careful periodic inspections can increase the equipment life 50,000 hrs beyond the fleet life. Further operation will demand replacement and repair of a large number of component and more rigid in-service inspections of the metal. In this situation, complete replacement of the turbine unit seems reasonable.

However, it should be considered that many existing TPS constructed 30-40 years ago have obsolete equipment which does not meet the modern requirement for efficiency and environmental impact. Continuation of their operation becomes unreasonable. Frequently, it is very difficult technically, or rather costly, to repower such TPS to improve the performance. 
A more attractive way is replacement using new technologies. The adequate economical substantiation of constructing efficient TPS with advanced equipment is next to impossible in Russia now.

\subsection{TPS Environmental Impact}

TPS, especially coal fired, are large environmental polluters [5].

The sanitary standards currently existing in Russia for regulating the maximum permissible concentrations (MPC) near ground-level of the major pollutant [6] are given below.

\begin{tabular}{|c|c|c|}
\hline Pollutant & \multicolumn{2}{|c|}{ MPC mg/m } \\
\hline & maximum & daily average \\
\hline Fly ash & 0.30 & 0.10 \\
\hline Same, for K-A coals & 0.05 & 0.02 \\
\hline $\mathrm{SO}_{2}$ & 0.50 & 0.05 \\
\hline $\mathrm{NO}_{x}$ & 0.60 & 0.06 \\
\hline $\mathrm{NO}_{2}$ & 0.085 & 0.04 \\
\hline $\mathrm{CO}$ & 5.0 & 3.0 \\
\hline Benz(a)pyrene & - & $1 \times 10^{-6}$ \\
\hline
\end{tabular}

For new TPS, the MPC of the ground-level contaminant have long been met in the U.S.S.R. by emission scattering through tall stacks.

Now, the State Standard has been prepared oriented to today's level of power engineering and gas cleaning equipment (up to 2001) and more stringent requirement after 2001. The norms of the Standard are given in Tables 1, 2, and 3 [7].

The strong position of local authorities and the public often force lower emissions than those specified in the Standards. Sometimes it is justified, i.e., in regions with high background industrial or transport emissions. Sometimes, implementing environment protection measures demands unjustifiable expenditures from the ecological and economical point of view.

The data on actual emissions of Russian thermal power stations in 1994 are given below. 


\begin{tabular}{|c|c|}
\hline Pollutant & Emissions, $10^{6} \mathrm{t}$ \\
\hline $\mathrm{SO}_{2}$ & 2,110 \\
\hline $\mathrm{NO}_{\mathbf{x}}$ & 1,210 \\
\hline Fly ash & 1,500 \\
\hline Total & 4,820 \\
\hline
\end{tabular}

Coal TPS are responsible for the major part of the emissions listed above.

Specific emissions, $\mathrm{g} / \mathrm{kWh}$ are strongly different for different coals.

\begin{tabular}{|c|c|c|c|c|}
\hline Pollutant & \multicolumn{4}{|c|}{ Coal grade } \\
\hline & Kuzn & $\mathrm{K}-\mathrm{A}$ & Donetk AC & Ekib \\
\hline Fly ash, slag & 82.0 & 29.0 & 103.0 & $250.0-420.0$ \\
\hline $\mathrm{SO}_{2}$ & 3.5 & 2.6 & 21.6 & $9.1-11.5$ \\
\hline $\mathrm{NO}_{\mathrm{x}}$ & 3.7 & 1.5 & 2.8 & $3.4-3.6$ \\
\hline
\end{tabular}

Some years ago, a considerable reduction of the TPS environmental impact was felt at the state level. The development of new environmentally friendly energy technologies, conventional boilers with lower or minimum emissions, and gas cleaning equipment and systems have been under way. They were carried out in accordance with the "Ecologically Clean Power Generation" State program, including the "Ecologically Clean Coal Power Stations" section. Much of the work was being done by manufacturers of equipment and energy enterprises at their own initiative. Though at present, the rate of environmental protection work in power engineering is reduced due to the economical difficulties in this country, the development are still under way and many of them have already gained positive result. 


\section{ELECTRIC POWER EQUIPMENT OF RUSSIA}

\subsection{General}

The electric power manufacturing industry of the former U.S.S.R. produced all kinds of equipment required for electric power stations: steam boilers, steam and hydro-power turbines, associated electric generators, transformers, auxiliary mechanical and electrical equipment, component and materials [1]. Brief characteristics of the thermal power station equipment used in Russia can be found in Section 1 of this report. The equipment in many respect meet the world's standards and ensures high reliability and economic efficiency. Some design data on large Russian TPSs; and a distribution of main equipment by manufacturer and rating can be found in Table 4.

The manufacture and operation of electric power equipment was based on domestic R\&Ds, metal, electronics, chemicals, etc. TPSs were constructed by large specialized organizations having all the necessary equipment and facilities. At the same time, there was a certain lag of the Soviet, and later Russian, industry in the development and manufacture of GT, automatic control systems, and gas cleaning systems and equipment.

Given below are some data on Russian TPS equipment and manufacturers.

\subsection{Steam Boilers and Associated Equipment}

The major utility boiler manufacturers for large power unit are Taganrog Boiler Manufacturing Works (TKZ) and the Podol'sk Boiler Manufacturing Works (ZiO). The scope of their shipment for the Russian large power unit can be seen from Table 4. These two boiler works also produced many subcritical-pressure boilers with steam output up to $670 \mathrm{t}$. Such boilers are likewise manufactured at the Barnaul Boiler Works (BKZ). Utility boilers of smaller capacity and industrial boilers are produced at the Biysk (BIKZ) and Belgorod (BEZM) works.

The domestic works manufacture boilers of various steam output, designed at different steam parameters and adapted to fire different fuels. The boiler fleet was updated continuously due to the use of new fuels, the reduction of harmful emissions, and the export of boilers [8].

All new boilers have been designed with suspended gas-tight waterwalls. The boilers are supplied as large-size transportable assemblies to provide for high quality, rapid erection, and 
commissioning.

Liquid and gaseous fuel fired utility boilers are produced in the range of $160-3,950 \mathrm{t} / \mathrm{h}$, 14-25 MPa, $560 / 560^{\circ} \mathrm{C}$ and $545 / 545{ }^{\circ} \mathrm{C}[9,10]$.

Despite significant differences in capacity and steam parameters, the domestic fuel oil boilers have much in common. All of them have $\Pi$-shaped layouts and have prismatic furnaces with all-welded water walls. The boilers can operate under pressure, are equipped with a gas recirculation system, and regenerative air heaters.

The 3,950- (Figure 4) and 2,650-t/h boilers for 1,200- and 800-MW unit are suspended from the building structures, and the remaining boilers are suspended from their frame.

For gas/oil boilers with prismatic furnaces the opposed, multi-tier swirl burners are used: three-tier burners for 800- and 1,200-MW unit boilers; and two-tier for $300 \mathrm{MW}$ and lower output unit boilers.

With close arrangement, only front burners are applied.

The $\Pi$-shaped, $320 \mathrm{t} / \mathrm{h}$ and larger boilers have a ledge at the back wall protecting the platens or the vertical bank of the convective superheater from direct furnace radiation.

Regenerative rotary heaters with rotor diameters from $5.4 \mathrm{~m} \mathrm{(429-,} \mathrm{320-,} \mathrm{and} \mathrm{160-t/h} \mathrm{boilers)}$ to $14.5 \mathrm{~m}(2,650-$ and $3,950-t / \mathrm{h}$ boilers $)$ are used for air preheating. To protect the heater packing against corrosion, the air is preheated and ceramic packing is used in the cold layer.

Boilers for firing coals with significantly different physical-chemical properties and mineral matter behavior are manufactured in a greater number of layout and technical design $[9,10]$.

The maximum capacity of domestic coal unit is $800 \mathrm{MW}$ for which 2,650 -t/h boilers had been specially designed to fire Berezovo brown coal (P-67, ZiO, Figure 5) and bituminous Kuznetsk and Donetk coals (TPP-804, TKZ). The P-57R, 1,650-t/h boiler was designed and manufactured by ZiO as 500-MW unit to fire high-ash Ekibastuz coal (Figure 6).

Brown coals, such as the strongly slagging Berezovo coal are fired in tangential furnaces. The square-section furnace used by $\mathrm{ZiO}$ in the $\mathrm{P}-67$ boiler ensured low-temperature firing 
with a dry-bottom, good aerodynamics, and uniform heat flux distribution, thereby providing no-slagging operation. The tangential-fired furnaces allow for staged combustion in the plane of each burner tier where the coal-air mixture and secondary air are directed at a certain angle.

The bituminous coal fired TKZ and ZiO boilers for $800-\mathrm{MW}$ and 500-MW are made with wall-mounted burners.

The solid fuel fired boilers of higher capacity are of the T-type layout.

These coal boilers are mostly of the dry-bottom design, with the exception of some 200- and 300-MW unit dedicated to fire anthracite culm and lean bituminous coals which are of the wet-bottom design. The new boiler project for these coals include both dry- and wet-bottom options.

The technical solutions laid down in the schemes and design of the component of coal boilers reflect the experience and traditions of manufacturers. So, for example, $\mathrm{ZiO}$ most widely applies steam-to-steam heat exchangers to control reheat temperature, whereas reheater interim stage bypassing is the practice of $\mathrm{BKZ}$, and gas recirculation and water injection are used by TKZ.

Flat-flame burners are widely employed by TKZ (TPP-804 boiler for 800-MW unit, TPE-215 boiler for 200-MW unit and unified series of $400-500-t / h$ range boilers).

$\mathrm{ZiO}$ and $\mathrm{BKZ}$ boilers mostly use tube air heaters. Characteristics of some coal boilers are illustrated in Table 5. To decrease $\mathrm{NO}_{x}$ formation, low- $\mathrm{NO}_{\mathbf{x}}$ burners of various designs are used. Two-stage combustion and reburning, flue gas recirculation, high concentrated coal dust supply, to mention but a few, are also applied.

Various methods and devices for cleaning the heating surfaces of slag and deposit are applied. Sliding pressure boiler operation has been mastered allowing for unit flexible operation and deep unloading in a "moderate" mode.

Both sub- and supercritical pressure boilers use low-alloyed perlitic steel (12X1MF) and highalloyed $\mathrm{Cr}-\mathrm{Ni}$ austenitic (12X18N12T) steel in addition to carbon steel. The ferrite family steels with high heat-resistance (up to $620^{\circ} \mathrm{C}$ ), among which the domestic example is EI-756, are also employed for some ZiO boilers, and also at foreign TPSs. 
The specific metal weight vary widely for coal boilers for which moderate furnace heat release rates and water wall heat fluxes are typical.

The highest metal weight are for boilers designed for high-moisture brown coals. The metal weight for pressurized part of P-67, P-78 $(1,650 \mathrm{t} / \mathrm{h})$ and TPE-216 boilers are 3.02; 3.57 and $4.09 \mathrm{t} /(\mathrm{t} / \mathrm{h})$, and the total metal weights are 7.4; 8.48 and $10.0 \mathrm{t} /(\mathrm{t} / \mathrm{h})$; the latter boiler is suspended from it own frame.

The design gross efficiency of the currently manufactured domestic gas/oil boilers is 92.5-94.0 percent, and that of coal boilers, 90.5-92.5 percent. The actual efficiency in some cases turned out to be below the design value with the difference reaching 2 percent. The causes are increased fouling and slagging of heating surfaces, their inefficient cleaning, increased suction in the furnace and convective boiler part, increased stack gas temperature, and poorer fuel quality.

To evaluate new furnaces and firing technologies some pilot coal boilers were constructed in the 1980s.

In 1984 , a $500-t / h, 14.0 \mathrm{MPa}, 560^{\circ} \mathrm{C}$ TPE-427 wet-bottom boiler was put into operation equipped with the TKTI vortex furnace to fire Kansk-Achinsk coals. The refractory, horizontal-lined furnace chamber with a diameter of $4.4 \mathrm{~m}$ and a width of $16 \mathrm{~m}$ was separated by two division walls into 3 compartment. The prismatic cooling chamber is $5.9 \mathrm{~m}$ deep. Six straight-flow burners are arranged over the front at an angle of 15 degrees to horizontal. The furnace volume heat release rate $\left(0.203 \mathrm{MW} / \mathrm{m}^{3}\right)$ is considerably higher than at existing E-500 and P-67 boilers (refer to Table 5). The boiler fires Berezovo and Nazarovo field brown coals. Despite modernization of a number of component and the fuel preparation system, the boiler can only operate continuously at $60-65$ percent of the nominal capacity due to superheater fouling.

The St. Petersburg Polytechnical Institute has developed low-temperature swirl combustion technology for crushed coal. The BKZ 420-t/h boiler has been redesigned to use this technology. The brown Irsha-Borodinsk coal in lumps of up to 25-mm size was used. To decrease the carbon loss, wear of water walls, and ensure design steam superheating some modernization was introduced into the boiler. As a result, the average load is 0.7-0.9 of the nominal value, carbon loss is 2 percent, furnace excess air is 1.37-1.41, and $\mathrm{NO}_{\mathrm{x}}$ emissions $470 \mathrm{mg} / \mathrm{m}^{3}$. 
Since the beginning of the 1980 s, experiment have been undertaken to fire coal in different versions of fluidized-bed boilers.

These small boilers with low-temperature fluidized beds have been designed by BIKZ in cooperation with TKTI. In 1985, first 10 - and then 16-t/h boilers were manufactured and reached nominal output. The carbon loss when firing Kuznetsk gas coal is $3-4$ percent maximum.

Work on combined flame and bed combustion were conducted by VTI and VNIIAM. The dry bottom hopper was provided with a nozzle screen whereto the coal ranging from 2-25 mm in size was fed. The fine fraction was directed to be milled and was supplied to the furnace via the PC burners. VTI conducted the work and fired Kuznetsk and Ekibastuz coal in 210and $160-\mathrm{t} / \mathrm{h}$ reconstructed $\mathrm{BKZ}$ boilers. Increased output and $\mathrm{NO}_{\mathrm{x}}$ reduction were obtained but the work was not finished.

Positive result have been obtained by VNIIAM for flame-bed combustion of shales at the 75-t/h boiler of the "Akhtme" cogeneration plant. However, the attempt to transfer the technology to a $250-t / h$ boiler was confronted with certain difficulties.

The Irsha-Borodinsk brown coal fired in a 420 -t/h bubbling fluidized-bed boiler (Figure 7) manufactured by BKZ in cooperation with TKTI and VTI. The furnace is of the four-section design arranged on two floors. Each section is provided with an air distributing grid which has the evaporative and superheating surfaces arranged in the bed of the granular material. The evaporative bank is located in the freeboard above the bed. Provision is also made for a separation space. The evaporative surfaces above the bed are studded to protect them against wear. The slag from the adjacent boilers is used as inert material.

According to predictions, $\mathrm{NO}_{\mathrm{x}}$ emissions will be of the order of $350-400 \mathrm{mg} / \mathrm{m}^{3}$, sulfur capture, up to 90 percent; and boiler path pressure drop, $20-29 \mathrm{kPa}$. The boiler test will start this year.

At the end of 1987, a program had been adopted in the U.S.S.R. to create CFB utility boilers, according to which BKZ in cooperation with TKTI and VTI had developed 500-t/h, 14-MPa, $565^{\circ} \mathrm{C}$, non-reheat $\mathrm{CFB}$ boilers. A boiler firing anthracite culm and using high-temperature cyclones [11] was designed for the Kurakhovskaya TPS, Ukraine (Figure 8).

A boiler for the Novomoskovsk TPS was designed to fire high-sulfur near-Moscow brown 
coal and employ cold cyclones. Similar boilers are being designed to fire Ekibastuz and Kuznetsk coals.

The anthracite culm-firing CFB boiler is made up of two furnace modules each of which has two cyclones and four ash heat exchangers. The furnace modules are combined by a single convective section. The furnace module dimensions in the upper and lower portions are $8.0 \mathrm{~m}$ long by $5.5 \mathrm{~m}$ wide and $7.4 \mathrm{~m}$ long by $2.5 \mathrm{~m}$ wide, respectively. The $1 \mathrm{st}$ and $2 \mathrm{nd}$ stages of the superheater, lst and 2nd stages of the economizer and air heater are located in the convective path. The calculated $\mathrm{NO}_{\mathrm{x}}$ and $\mathrm{SO}_{\mathrm{x}}$ emissions are at $200 \mathrm{mg} / \mathrm{m}^{3}$.

Much has been done in the U.S.S.R. to introduce higher supercritical steam parameters. In 1949, at the VTI Experimental cogeneration plant a pilot boiler was constructed, designed for $30 \mathrm{MPa}, 600^{\circ} \mathrm{C}$ (later $650^{\circ} \mathrm{C}$ ), which has been in successful operation since that time. At the Kashira TPS, the SKR-100 power unit was put into operation in 1966 employing a ZiO manufactured PK-37 boiler rated for $710 \mathrm{t} / \mathrm{h}, 31 \mathrm{MPa}$ and $650^{\circ} \mathrm{C}$ live steam, and $9.8 \mathrm{MPa}$, $565^{\circ} \mathrm{C}$ reheat parameters. The steam was supplied to the high pressure steam turbine, and after being expanded there was directed to the existing $\mathrm{K}-60$ turbines at $3 \mathrm{MPa}, 400{ }^{\circ} \mathrm{C}$. To manufacture boiler outlet component and steam pipes high-alloyed austenitic steels EP-184 and EP-17 were designed wherein the Ni content was increased to 17-18.5 percent.

The unit operated for 30,000 hrs at a boiler outlet temperature of $630-640^{\circ} \mathrm{C}$ and a short-term live steam temperature rise of up to $650-655^{\circ} \mathrm{C}$. The residual life of the unit equipment is now about $100,000 \mathrm{hrs}$.

Along with traditional boilers, Russian manufacturers produce some special-purpose utility equipment. For example, the Russia's Taganrog boiler manufacturing Works (TKZ, Taganrog, Rostov district) has experience in designing and manufacturing the supercharged steam generators (SSG) for combined cycle plant. Such steam generators are located between the compressor and turbine of the GT unit. They all use compressed air and fuel to be fired at excess air rates close to that used in the conventional boilers. The released heat is utilized to generate and superheat the steam fed to the steam turbine. The combustion product are cooled down to the acceptable temperature in a heat exchanger and are expanded in a gas turbine to a pressure close to atmospheric.

A 200-MW natural gas CCP (30-MW GT, 150-MW steam turbine) with a 450-t/h supercharged steam generator $\left(14 \mathrm{MPa}, 545 / 545^{\circ} \mathrm{C}\right)$ was constructed in Russia, and since 1973 has been in operation at the Nevinnomyssk TPS. The gas pressure in the supercharged 
steam generator is about 6.5 bar, and the turbine operates with inlet gas temperatures up to $770^{\circ} \mathrm{C}$. This CCP has been in operation for more than 130,000 hrs.

Later, supercharged steam generators of 600 and 655 -t/h steam capacity were designed and prepared for manufacture for a 250-MW CCP (50-MW GT, 200-MW steam turbine) that would use natural gas and low-calorie gas - the air-blown coal gasification product. The layout of a SSG-650 is illustrated in Figure 9. The 250-MW CCP employs two such unit located symmetrically with respect to the GT axis (see section 6.5 ).

TKZ also produces HP feedwater heaters for power unit of up to 1,200 MW.

Another large boiler manufacturing works of Russia - ZiO - is located in Podol'sk (near Moscow). About 700 boilers have been produced at that works for more than 140 domestic and foreign (Poland, Rumania, Bulgaria, Germany, Greece, China, etc.) TPSs of total capacity over $64 \times 10^{6} \mathrm{~kW}$, including $13 \times 10^{6} \mathrm{~kW}$ for export.

For CCPs ranging from 16-800 MW, heat recovery boilers of various capacity have been designed at the $\mathrm{ZiO}$ works. Such boilers widely employ spiral-finned pipes produced successfully at the $\mathrm{ZiO}$ works ( 8 lines for tube finning of up to $20,000 \mathrm{t} / \mathrm{y}$ capacity). The available equipment allows for tube finning of all kinds of steels ranging in diameter from 22-114 mm with rib height up to $35 \mathrm{~mm}$ and spacing ranging from $4-24 \mathrm{~mm}$.

Since 1931, ZiO has produced equipment for refineries and allied branches of industry. Now, it annually supplies up to 700 items for column, tank equipment, heat exchangers and tube furnaces for a total volume of up to 20,000 tons. More than 40 refineries are fitted with ZiO equipment. Some items of equipment have been manufactured for foreign companies. Among them are rectification columns, stabilizers, absorbers, desorbers, evaporators of up to $3.4 \mathrm{~m}$ in an assembled state (for larger diameters the items are shipped to be assembled at the site), heat exchangers, tanks for various processes, product coils for furnaces, etc.

ZiO has been certified to the ASME standards with reference to boilers and pressure vessels. In 1994 the work was completed to certify ZiO in quality by ISO 9000 Standard (it is carried out by Lloyd Register). Certification by DIN is under way.

The "Belenergomash" (BEZM, Belgorod, Central Russia) can serve as an example of an enterprise producing small boilers. It's specialty is low and medium capacity boilers for TPSs, heat recovery boilers for metallurgy, chemical, wood- pulp and paper industries, and 
small boilers and boiler houses for residential heating. BEZM produces:

- saturated or superheated steam boilers of $35,50,75,100$ and 165 th operating on natural gas, fuel oil, bituminous and brown coals, and wood wastes;

- gas- and water-tube boilers from 0.4-15 $\mathrm{t} / \mathrm{h}$;

- gas-, water-tube and spiral hot-water boilers from 0.1-10 MW;

- equipment for small boiler houses: deaerators, chemical cleanup plant, heat exchangers;

- water- and gas-tube heat recovery boilers for cooling process gases (converter gas, dry coke quenching, etc.);

- boilers for burning black liquor (soda regeneration), hydrogen sulfide, wastes of soot production, etc.;

- hot-water boilers of up to $106 \mathrm{MWt}$ in capacity; heat-recovery boilers with the spiralfinned tubes utilizing GT waste gases ;

- utility boilers of different types.

Belenergomash is also Europe's largest producer of pipes, shaped part and pipe packages for TPS and NPP. The works has bending machines both conventional and with local induction heating to manufacture bends of up to $630 \mathrm{~mm}$ in diameter using carbon and Cr-Mo steels, and up to $325 \mathrm{~mm}$ using austenitic steels; machines for tube cutting and welding, pressforging plant for stamping t-pieces and bends, and equipment for casting of shaped component.

The equipment for coal handling and pulverizing (conveyors, crushers, mills of various designs, etc.,) is produced by SZTM Works in Syzran' (Middle Volga).

HP valves (dampers, pressure-reducing unit, etc.) are issued by the ChZEM Works in Chekhov (near Moscow). 


\subsection{Steam Turbines}

Steam turbines for large power unit are mostly manufactured by the Leningrad Metal Works (LMZ, St. Petersburg) and Kharkov Turbine Works (KhTZ, Kharkov), while the turbines for combined heat and power generation are made by the Urals Turbomotor Works (TMZ, Ekaterinburg). These works produce single shaft turbines of 30-1200 MW for driving electric generators.

Basic technical data on the largest Russian-made steam turbines are illustrated in Table 6 [12].

The condensing turbines feature the following peculiarities.

The K-160-130 turbine (KhTZ) is of a two-cylinder design with a combined HP and IP cylinder and one two-flow LP cylinder.

The K-200 turbine (LMZ) is of the three-cylinder design with separate HP and IP cylinders and two-flow 1.5 exhaust LP cylinder.

The K-300 turbine features three exhaust. The IP cylinder is combined with one LP cylinder flow which passes $1 / 3$ of the entire steam.

The modern turbines of larger capacity are made with a single-flow HP cylinder, single or two-flow IP cylinders and one or several (up to 3) two-flow LP cylinders. The typical design of a HP cylinder with loop steam flow applied by LMZ and TMZ is shown in Figure 10, and the typical LP cylinder is illustrated in Figure $11[13,14]$.

Unit of 30-185 MW are designed at 3-13 MPa and 430-555 ${ }^{\circ} \mathrm{C}$ without reheat and are mostly used for combined electricity and heat production at industrial enterprises and in utilities [15]. The extraction turbines have regulated steam extractions to supply steam for industrial users and to heat water for heating systems. The heating is done in 2-3 stages for better efficiency. Also, back-pressure turbines operating at pressures up to $3 \mathrm{MPa}$ are available with output up to $100 \mathrm{MWe}$.

The larger turbines (180 MW) for cogeneration, and (150-200 MW) for condensing TPS are designed with reheat at $13 \mathrm{MPa}, 540 / 540{ }^{\circ} \mathrm{C}$. 
The TMZ turbines dedicated for combined electricity and heat generation are made so that the nominal capacity is ensured at a nominal heat rate and a minimum steam flow to the condenser. In this case, the turbine cycle efficiency is maximum. The exception is the supercritical pressure reheat T-250 turbine. It carries it maximum electrical load of $305 \mathrm{MW}$ in the condensing mode, without steam extraction.

The IP part of this T-250 extraction turbine is divided into two cylinders. Large steam pipes are connected to the top and bottom extraction point for IP cylinder No. 2. The steam is used to heat district heating water. In 100-, 180-, and 250-MW turbines steam is extracted for these purposes at 50-60 and $150-200 \mathrm{kPa}$. The maximum amount of extracted steam is 320 , 490 and $600 \mathrm{t} / \mathrm{h}$ respectively. In a $250-\mathrm{MW}$ turbine unit, up to $385 \mathrm{MWt}$ of heat is extracted.

The process heat is extracted at 1.3-2.0 MPa.

Condensing steam turbines rated at $300 \mathrm{MW}$ and more are manufactured for operation at supercritical (24 MPa) steam pressure with $540 / 540{ }^{\circ} \mathrm{C}$ reheat.

All Russian-made steam turbines of up to $800 \mathrm{MW}$ inclusive have nozzle steam distribution. The flow path is made up by impulse stages with positive reaction in the root section and aerodynamically perfect blades, as a rule, with variable profiles along it. To increase efficiency and dampen bucket vibration, bucket are made with shrouds. This and blades machined from one piece is the latest design for IP and LP cylinders. Axi-radial seals are provided over the shrouds.

In conventional use are diaphragm-type designs of nozzles and integral-disc types of rotors that are generally supercritical, and for the LP part they mostly use shrunk-on discs. With Russian-made steam turbines there were no difficulties due to rotor stress corrosion cracking because less strong steels having a higher ductility were used.

The bucket in the heavily-loaded stages of the LMZ turbines are fastened by fork root; in the less loaded stages by T-shaped root; and in the last stages the long bucket are fastened by serration type root. Interchannel systems of moisture separation and liquid film removal in the rim gap are used in the LP cylinders.

The turbines manufactured now can operate under loads from 20-115 percent. Some characteristics of existing LMZ supercritical steam turbines are given below. 


\begin{tabular}{|l|c|c|c|c|}
\hline \multicolumn{1}{|c|}{ Parameters } & \multicolumn{4}{c|}{ Type of Turbine } \\
\hline & $\mathrm{K}-300$ & $\mathrm{~K}-500$ & $\mathrm{~K}-800$ & $\mathrm{~K}-1200$ \\
\hline Maximum output, MW & 330 & 540 & 870 & 1400 \\
\hline Specific heat consumption, kJ/kWh & 7704 & 7641 & 7683 & 7616 \\
\hline Specific weight, kg/kW & 2.3 & 1.9 & 1.5 & 1.47 \\
\hline Nonscheduled outage, \% & 1.5 & - & 0.7 & 0.6 \\
\hline Number of unit in operation & 55 & 5 & 15 & 1 \\
\hline
\end{tabular}

The efficiency of the HP, IP and LP cylinders of supercritical turbines now in operation are 84-86 percent, 91-92 percent and 82.5 percent, respectively. More efficient turbines have been designed (first with increased efficiency of the LP cylinder) with a specific heat consumption of $7300-7500 \mathrm{~kJ} / \mathrm{kWh}$.

The Russian-made steam turbines are reliable in operation. Availability factors of 200-1,200-MW steam turbines are 97-99 percent, and the time between overhauls is 4-5 years with operation of up to $6,000-7,000 \mathrm{hrs} / \mathrm{y}$. The time between failure is $10,000 \mathrm{hrs}$.

To ensure the strength and reliability of the component and increase the efficiency of the turbine flow pass, state-of- the-art computer codes (in recent years 3D codes) are used. The Works, Research Institutes and Universities have test facilities and experimental turbines (at LMZ a full-scale LP cylinder with 960 and 1,200-mm long last stage blades) to investigate the flow path and component of steam turbines.

Some unique technical achievement [13] are:

- $\quad 50-M W$ control stage of LMZ steam turbines made-up of bucket that use design damping were welded in packages by an electron-beam welding technique

- LP cylinder last stage bucket $1,200 \mathrm{~mm}$ long made of titanium alloy (the annular area of the stage is $11.3 \mathrm{~m}^{2}$, circumferential velocity over the periphery is $658 \mathrm{~m} / \mathrm{s}$ ) which have been in successful operation since 1983;

- LMZ turbines for PPNs are using one-piece forged LP turbine rotors weighing $80 t$ without boring at $3,000 \mathrm{rpm}$ 
Russia has successful experiences in the operation of 300- and 800-MW turbine unit without deaerators using direct-contact LP heaters where feedwater deaeration is provided, which is sufficient with a neutral-oxygen water chemistry regime.

The turbine extractions for industrial and heating applications are controlled by adjustable diaphragms.

The turbine manufacturers produce for their turbines' condensers with copper-nickel, titanium alloys, and stainless steel tubes. They produce water heaters for heating systems; condensate and feedwater heaters, both surface-types with tubes made of various materials and directcontact; deaerators; evaporators; oil coolers and heat exchangers for district-heating systems; and auxiliary heat exchangers.

Synthetic fire-resistant OMTI oil has found application in LMZ turbine lubrication and control systems. Some turbines of 300 and $800 \mathrm{MW}$ have been in operation some tens of thousands hrs using OMTI in the lubrication systems. It is also used on all LMZ 1,000-MW turbines at NPP.

For Russian manufacturers wide standardization of technical solutions is typical in the design and manufacture of steam turbines. Identical blade profiles, nozzle blades and bucket, especially of last stages, valves, seals, bearings and other component and systems are used.

Steam turbines of smaller capacity, up to 25-30 MW, are manufactured by the Kaluga Turbine Works (KTZ, Kaluga) to drive electric generators and feed pumps, and by the Nevsky Works (NZL, St. Petersburg) to drive electric generators and compressors.

High-speed steam back-pressure turbines of about $12 \mathrm{MW}$ and condensing turbines of 11-12 and $17 \mathrm{MW}$ are produced for driving feed pumps. Similar turbines of $6.5 \mathrm{MW}$ are manufactured to drive air blowers (fans) of 800 and 1,200-MW unit boilers.

\subsection{Gas-Turbine Unit}

The former U.S.S.R and later Russia has long-term experience in GT operation at TPS and main gas pipelines. In the national economy GT unit developed and constructed by power machine manufacturers, and also aircraft and marine derivatives are used.

The land GT are mostly applied in Russia to pump natural gas at main pipe lines. Currently 
the total capacity of GT unit used for this purpose amount to about $40 \mathrm{GW}$ with unit capacity ranging from 4-25 MW. The most upgraded unit operate at a turbine inlet temperature of $1,060-1,100^{\circ} \mathrm{C}$ and an efficiency of 32-35 percent. However, the majority of these unit belong to the first generation with uncooled bucket and vanes, and they operate at a turbine inlet temperature of $760-920^{\circ} \mathrm{C}$.

Such GT are supplied in packages of works manufacture. As a rule, prior to shipment, GT are tested at the works rig under load or at nominal gas temperature. Most of GT operate in severe climatic conditions, and in low-population areas lacking the required infrastructure, transport communications, and transmission lines. Some of the gas pipeline GT' parameters can be found in Table 7.

GT units are made with a free running power turbine and can be used for electric generator driving applications via reducing gear.

For power generating GT characteristics, refer to the same Table 7.

Large heavy-duty GT unit dedicated for electric power generation were manufactured by LMZ (St. Petersburg) and KhTZ (Kharkov); heavy-duty GT unit for the gas industry were manufactured by NZL (St. Petersburg) and TMZ (Ekaterinburg, Urals). For the layout of a GT rated of $150 \mathrm{MW}$ see Figure 12.

The big suppliers of 10- to 12-MW GT unit for electric generation and the gas industry are "Mashproject" and YuTZ in Nikolaev (Ukraine). Currently the Works (industry) produce(s) GT unit for the next generation of 2.5-25 MW turbines with better characteristics, particularly for the power industry. "Mashproject" has worked out, using it advanced technology, a single-shaft state-of-the-art GT rated at $110 \mathrm{MW}$ [16]. This GT will be manufactured in cooperation with the Russian "Rybinskije motory" Works (Rybinsk, Upper Volga). The first GT of this type will be produced this year.

A large number of aircraft-derivative GT of 6.3 and $16 \mathrm{MW}$ have been manufactured for the main gas pipelines by the "Trud" Aircraft engine enterprise in Samara (on the Volga River). Operation of the latest model, NK-36ST, has started at the gas pipeline. The Utility version [17] of this GT unit, NK-37 (Figure 13), is being tested on-load at the pilot plant. Some GT units of this kind have been ordered to be used in 80-MW CCP (2 GT + ST) which are now under construction. The design and supply of this CCP is performed by the Kirov Works (St. Petersburg). 
In recent years, the activity of aircraft engine developers and manufacturers in marketing land (fixed) GT unit in Russia has increased. Based on their GT engines they have developed efficient utility and mechanical driving GT unit rated from 1.5-25 MW. Operation of such GT will be started in the near future. The data for the most promising unit are illustrated in Table 8.

Various gas-turbine manufacturers already have agreement or are conducting negotiations with leading Western firms (LMZ-Siemens, NZL and Saturn-ABB, Kirov Works and Rybinskije Motory-GE, etc.).

Some project using combined cycle unit have been developed in Russia with various types of GT. The data for the most efficient project is presented in Table 9.

The technologies of Russian aircraft engine manufacturers are at the top level. Yet, the heavy-duty GT manufacturers have fallen behind the leading Western firms in parameters and in the number of GT produced, in particular, for power generation. However, Russian manufacturers have designed many samples of high-efficient equipment for their GT.[18,19].

About 20 types of efficient air paths have been perfected for axial compressors ranging by flow from $30-700 \mathrm{~kg} / \mathrm{s}$, pressure ratio from 2 to 13, and adiabatic efficiency of 85-90 percent. In many cases, the compressor flow paths are provided by using the group stages of previously developed and operationally proven machines [19].

The development of high-temperature component for turbines are based on experimental investigations, mathematical modelling, and computer programs that allow for the calculation of thermal stress and the evaluation of the durability of component over all of the blades.

The vanes with deflector cooling systems have a long operating history with GTN-16 (TMZ) and GTN-25 (NZL) GT unit.

The first stage bucket with original internal cooling (Figure 14,c) had been used for the GTN-25 (TMZ) turbine some 10 years ago. When using 2.5 percent of the air taken past the compressor, the metal temperature of the bucket was reduced by $250 \mathrm{C}$ at low $\left(70^{\circ} \mathrm{C}\right)$ temperature gradient.

- For sufficiently long bucket of large GT unit, use is also made of channel and loop-type cooling systems that are capable of reducing the maximum bucket metal temperature to 
$800-825^{\circ} \mathrm{C}$ with a turbine inlet temperature of $1,100^{\circ} \mathrm{C}$ and cooling air flow of $1.7-3$ percent.

The properties of Ni-based alloys used for blade manufacture of heavy-duty GT are shown in Table 10 [20]. The mechanical properties have been determined at $20^{\circ} \mathrm{C}$ after ageing at $750{ }^{\circ} \mathrm{C}$ for $3,000-5,000 \mathrm{hrs}$. The creep-rupture strength is based on a service life of 20,000 hrs. $\quad$

The most experience available now with a blade operating at up to $700-750{ }^{\circ} \mathrm{C}$ is with the alloy EI-893. At many GT unit, the blades made of this alloy have been in operation for over $60,000 \mathrm{hrs}$. To increase operability, the blades are protected against corrosion by coatings.

For the GT unit manufactured now, the forged bucket are made of EI-929VD, EP-800VD, and EP-957ID alloys. The cast blades are made of EP-539-LMU, TcNK-7 and ZMI-3 alloys.

Some years ago, casting with directional solidification had been mastered for manufacturing the bucket for GTN-25 unit (NZL) which have been in operation for some tens of thousands of hours. The directional solidification has markedly improved ductility and the creep-rupture strength of bucket [20]. The technology has been adapted to manufacture large cooled bucket:

Various types of combustors are in use for the Russian-made heavy-duty GT unit, viz., silo, can-type and annular. For all of these combustors stable and efficient firing of natural gas, and liquid fuel was obtained in various operating conditions and modes whenever required. The component of the combustors exhibited a long service life.

In designing the existing $\mathrm{GT}$, little attention had been paid to $\mathrm{NO}_{\mathrm{x}}$ emissions. Now, the combustors of existing GT have been modified to reduce $\mathrm{NO}_{x}$ emissions. For the new $\mathrm{GT}$ unit, low- $\mathrm{NO}_{\mathrm{x}}$ combustors have been designed that satisfy the modern standards $\left(\mathrm{NO}_{\mathrm{x}}<\right.$ $50 \mathrm{mg} / \mathrm{m}^{3}$ ) without water/steam injection when using natural gas.

The work on direct coal combustion in GT was conducted in the U.S.S.R as far back as the 60s. Then some 3- and 12-MW GT unit firing gases derived from underground coal gasification were constructed and put into operation. The gas used was similar in composition and properties to the coal-derived gas obtained by the air-blown Lurgi gasification method. Combustion of that gas caused no problems.

Intermediate air coolers, tubular and plate air heaters, heat-recovery boilers and water heaters 
for heating systems have been designed, tested and operated for long periods with different GT units 


\section{THE POWER INDUSTRY DEVELOPMENT FORECAST FOR RUSSIA}

The essential goals of the Russian energy strategy are to promote social and economic revival of the country and increase the GNP, income, life standard and it quality, and reduce the man-made load on the environment [21].

The priority lies in increasing energy efficiency and conservation.

In 10-15 years a more effective use of natural gas and a larger share for it in domestic consumption are scheduled. The quality of coals will be improved by producing smaller amount of high-ash, high-sulfur coals through washing and benefication.

The development of the regions is planned in a way that will ensure their self-sufficiency in electricity, heat, and wherever possible in fuel, while preserving the United Power Grid of Russia.

If economically justified, smaller sources of electrical energy and heat will be provided as close as possible to the consumer. It will be based on economically efficient and ecologically clean technologies, particularly for coal TPS.

Some forecast made just after the collapse of the U.S.S.R. and at the start of the transmission of Russia to a market economy can be seen in Table 11. The forecast are based on the economical demands of the main regions of Russia and are still reasonable. Of course, the forecast could not take into account the depth and consequences of the economical crisis in today's Russia. However, with an optimistic view to the future and hope in the revival of the Russian economy, the figures of Table 11 are of present interest but are not attainable by the year 2010 , as supposed, but by some later year.

One can see from Table 11 that for the addition of considerable new capacity, mostly fossilfueled TPSs, is required to solve the social and economic problems, while increasing the standard and quality of life.

Coal is and will remain, in the near future, the basic fuel in Siberia and the Far East. It is also a very important fuel in the Urals and in the European part of the country. Coal consumption for power generation should double and constitute over $200 \times 10^{6} \mathrm{tfe} / \mathrm{y}$ in the future.

The prospect for the evolution of the Russian power industry are now uncertain. In recent 
years, due to economic difficulties and because of the transition to free market conditions, the consumption of electric energy was reduced and is going to decrease further. By 1995, electric generation is predicted at $850 \times 10^{9} \mathrm{kWh}$ which is 3 percent lower compared to 1994 .

The revival of the Russian economy is predicted in a long period of time. By various estimates, electric generation will reach the 1990 level in the years 2000-2010. In the near future, no high-investment construction of large TPS is planned. In 1994, only 25 hydropower and steam turbines were put in operation for a total capacity of $2.4 \mathrm{GW}$, including an 800-MW natural gas fired unit at the Nizne-Vartovsk TPS in the Tumen region.

Currently in Russia, mostly in the Eastern and Central regions of Southern Siberia and the Far East, there are some coal-fired TPSs under construction located near brown coal open-cast deposit. Some of them, for example, the Gusinoozersk and the Kharanorsk condensing TPS are in energy-deficient areas. Both TPSs have been designed to employ 215-MW unit. At the Gusinoozersk TPS, 6 such unit are in operation and two unit are scheduled to be started. At the Kharanorsk TPS, the first unit is being prepared for start-up and 6 unit will be commissioned in all.

At the Betezovo TPS N.1, two $800-\mathrm{MW}$ unit are in operation but the construction is not completed yet. The equipment for unit No. 3 is at the site. The Berezovo coal seam, where coal is the cheapest in Russia, can supply 4 unit now, and after further development can supply two additional TPS of $6.4 \mathrm{GW}$ each.

Several cogeneration plant are under construction or being prepared for construction. They will be equipped with 320-670-t/h boilers and 80- to 185-MW turbines.

The main attention is being paid to the radical reconstruction of the existing TPSs and the preparation for using up-to-date technologies. The worn-out and obsolete equipment, which have an overall capacity of about $90 \mathrm{GW}$, will be put out of operation.

The analysis of energy use in Russia made by several independent Western and Russian organizations indicates that:

- even without the decommissioning of some NPP and

- provided that existing TPS will expire their service life there will be a considerable power deficit in Russia, if new capacities are not put into operation. The deficit are as 
follows:

$\begin{array}{lll}\text { Calendar year } & 2000 & 2010 \\ \text { Power deficit, GW } & 24-56 & 149-174\end{array}$

About 80 percent of the deficit is attributed to the European regions and Urals which have insufficient fuel resources.

The deficit can be partially covered by a life extension of the existing equipment together with the replacement of the worn-out component. This approach is economically justifiable mostly for cogeneration plant. It could be implemented for equipment with a total capacity of 10-15 GW by the year 2000 and another 10-15 GW by 2010. With reference what can be done by 2010 , it will cover only 20 percent of the overall demand. The remaining deficit will be covered by construction of new power unit instead of decommissioning at existing TPS (in the same main building or at the same site). New construction will include both cogeneration and condensing TPSs. TPS retrofitting/repowering will be implemented along with increasing the efficiency (in particular, by increasing the share of combined heat and electricity generation) and decreasing the environmental impact.

Further growth of electric generation will depend on the rates of restoration of the country's economy. If they will be decelerated, and the energy saving be realized at a large scale and efficiently, a small number of relatively low-capacity new condensing plant will suffice, together with cogeneration plant, including those of low and medium capacity.

At higher rates of energy use, construction of some large condensing K-A and Kuzn coal-fired TPS in Siberia, the Urals, and maybe in the Volga River region will be needed. For such TPS, the use of $300-$ to $500-\mathrm{MW}$ unit is under consideration.

Along with cogeneration plant, a significant fraction of the heat required for consumers will be generated in the boiler houses (district heating plant). The steam capacity of the boilers installed there will be from 1-2 to $160 \mathrm{th}$, while that of hot-water boilers, up to $200 \mathrm{Gcal} / \mathrm{h}$ $(230 \mathrm{MW})$. Now, many of them are of low efficiency and operate with considerable $\mathrm{SO}_{2}$, $\mathrm{NO}_{\mathrm{x}}$ and fly ash emissions. The boiler houses could also be the places, where clean coal technologies could be applied.

The Energy Strategy is based on the fact that the coal industry will play the important role supplying the country with fuel, electricity and heat. 
The strategy is to terminate the drop of coal production, stabilizing it at $250-270 \times 10^{6} \mathrm{t} / \mathrm{y}$ level, continue the restructuring of the coal industry with the greater share of the open-cut coal production and the closing of unprofitable enterprises by the year 2000. In so doing, the following options of coal production evolution are considered.

\begin{tabular}{|c|c|c|c|c|c|}
\hline \multirow{2}{*}{ Coal annual production } & 1990 & 1993 & 1995 & 2000 & 2010 \\
\hline Maximum: $10^{6} \mathrm{t}$ & 396 & 306 & 270 & 290 & 340 \\
\hline $10^{6} \mathrm{tfe}$ & 257 & 196 & 172 & 185 & 210 \\
\hline GJ & 7530 & 5740 & 5040 & 5420 & 6150 \\
\hline Minimum; $10^{6} \mathrm{t}$ & - & - & 260 & 250 & 300 \\
\hline $10^{6} \mathrm{tfe}$ & - & - & 166 & 160 & 190 \\
\hline GJ & - & - & 4860 & 4690 & 5670 \\
\hline
\end{tabular}

In the European part of the country the coal production will tend in general to decrease, while that in the Kuzn and K-A fields will increase to supply the regions of Siberia and the Urals where these coals will be fired at TPS. The remaining regions will, to a greater extent, use local coals. The brown coal production is supposed to be increased in the Eastern region of the country in the Irkutk district, Zabaikalie, Primorsk and Khabarovsk regions from about $50 \times 10^{6} \mathrm{t} / \mathrm{y}\left(17 \times 10^{6} \mathrm{tfe} / \mathrm{y}\right)$ produced at present to $90 \times 10^{6} \mathrm{t} / \mathrm{y}\left(30 \times 10^{6} \mathrm{tfe} / \mathrm{y}\right)$.

The problems of transporting the cheap K-A and Kuzn coals to industrialized regions of the Urals and the East of the European part of the country are rather acute. It is clear that the handling of a greater portion of coal to raise it heat value prior to transportation will be required along with possible development of special transport means and systems.

Economical estimates provide evidence about competitiveness of Kuzn and K-A coals as fuel for TPS in the Urals, Volga River region and, may be, in the areas to the East from Moscow. For interregional transportation, mostly Kuzn coal or processed, for example, briquetted, K-A coal will be involved. The demands in solid fuel for the Eastern Siberia and Far East will be covered by local production and shipment of K-A coals. The Peach coals will be used in the Northern regions, and the coals from the Eastern Donbas, in the South of the European part of Russia. 
The Energy Strategy of Russia plans to distinguish the central and local energy control functions.

The Federal Governmental Bodies will control the activity of Federal power systems and the nuclear power industry, manage the strategic energy resources, establish the standards and norms of safety and efficiency of energy object, supervise their observance, license economic activity of utilities and regulate the activity of natural monopolies by legislative and normative act and by holding their shares.

The local (regional) authorities will set up functioning of the enterprises that are not part of the Federal power systems, issue licenses for construction of new and expansion of the existing TPS and specify additional environmental requirement for them.

Together with the Federal bodies, they will license the activity of the enterprises belonging to the Federal power systerns and responsible for reliable electricity and heat supply to the consumers, and also check the execution of the licenses granted.

The regional authorities will have the right required to provide for stable energy supply to the territories under their jurisdiction, state control of electricity and heat tariffs, establishing the energy market at their territories, including participation of independent producers.

The Energy Strategy of Russia declares the equal opportunities for domestic and foreign organizations and companies in the course of mutually beneficial cooperation and welcomes any forms of participation for foreign capital in the power industry of Russia. 
3-6 


\section{CLEAN COAL TIECHNOLOGY DEMONSTRATION PROGRAM (CCTP) OF U.S. DEPARTMENT OF ENERGY}

\subsection{General}

In the U.S., the clean coal technology program (CCTP) has been underway since 1985 aimed at:

- environmental protection by elaboration and industrial-scale use of economically effective and environmentally low-impact technologies for coal-based electricity generation;

- ensuring the reliable and safe power supply to the country through the development of processes and equipment for direct, or with some conversion, efficient use of coal instead of oil and natural gas;

- increasing the competitiveness of American industry in the external market through the development and industrial application of the above technologies and equipment.

Within this program R\&D and demo project are being developed. The scale of the latter is so selected that the result obtained are sufficient to assess all aspect of designing, constructing, and operating industrial plant $[22,23,24]$.

The program for ecologically clean technologies for coal utilization is financed by the government in cooperation with commercial firms, and other institutions. The program builds demo plant using selected technologies that show the most promise for advancement to the market during the next decade. The capacity of such plant shall be sufficient to get evidence (data) on their commercial potential.

Traditionally, DOE undertakes long-term R\&D programs for TPSs that have high risk and the potential to be effective. Since the fulfillment of the program at commercial scale was a high risk, DOE undertook full or almost full financing.

The clean coal technology program is realized on the basis of agreement between the government and commercial firms bearing at least 50 percent financing. The patent right to inventions are the property of all sponsors. 
The program was based on five independent competitive solicitations.

The project were selected from the offers by commercial firms that were based on technologies that the given companies thought to be most promising.

The execution of the project is supervised by the Pittburgh and Morgantown Energy Technologies Centers.

Currently 47 project selected in 5 competitions are underway in accordance with the Clean Coal Technology Program that was started in 1985. The total cost of the project is over $\$ 6.5 \times 10^{9}$, including $\$ 2.7 \times 10^{9}$ out of the Federal budget.

At the initial stages the program was mostly oriented to project that would decrease $\mathrm{SO}_{\mathrm{x}}$ and $\mathrm{NO}_{\mathrm{x}}$ emissions responsible for acid rains. Various devices and systems to decrease these emissions are being developed within the framework of 19 project at a total cost of $\$ 688 \times 10^{6}$. Among them are project of $\mathrm{NO}_{\mathbf{x}}$ reduction (Table 12) at power plant with an overall capacity of $1,700 \mathrm{MW}, \mathrm{SO}_{2}$ reduction at power plant of $770 \mathrm{MW}$ (Table 13) and combined $\mathrm{NO}_{x}$ and $\mathrm{SO}_{2}$ reduction (Table 14) at power plant with an overall capacity of $765 \mathrm{MW}$. The technologies have been designed to be adaptable to newly constructed and existing TPSs. With reference to the majority of the project, test result and operating experience are available. Some of the project have already been completed and some of them are being implemented for commercial use. The total data on the efficiency of various gas cleaning technologies can be found in Table 15.

Later, as CCTP progressed, greater attention was being paid to the development of advanced AFBC and PFBC technologies, CCPs with integrated coal gasification (IGCC), and other technologies (Table 16) that offered higher efficiencies, reduced $\mathrm{CO}_{2}$ and rather low $\mathrm{SO}_{2}$ and $\mathrm{NO}_{x}$ emissions, and also better performance. 15 project, at a total cost of $\$ 4.7 \times 10^{9}$, belong to this group. The project are being realized at new TPS with a total capacity of $1200 \mathrm{MW}$ and existing TPS of total capacity of $800 \mathrm{MW}$.

The operating result for the majority of the power plant will be available in the second half of the 1990s.

CCTP also includes 5 project for processing coal to clean fuels at a total cost of $\$ 467 \times 10^{6}$ and 6 project for industrial power plant that offer increased efficiency and better ecological parameters at a total cost of $\$ 1.118 \times 10^{9}$. Also included is an integral facility for coke-free 
iron production and electricity generation with a CCP firing coal-derived gas at a total cost of $\$ 825 \times 10^{6}$.

\subsection{Project for Reducing Emissions from Conventional Boilers}

To reduce $\mathrm{NO}_{\mathrm{x}}$ emissions, low-NO $\mathrm{No}_{\mathrm{x}}$ burners and staged combustion with overfire air are used. These technical solutions ensure $\mathrm{NO}_{\mathrm{x}}$ reduction by 40-60 percent for a small capital investment $(<\$ 10 / \mathrm{kW})$, some loss in efficiency $(<0,2$ percent), and an operating cost penalty. The implementation of these measures do not require much time as shown in Table 12. (Project 7-46 and 7-48 in Table 12, and 7-66, Table 14 are examples of this technology. The project numbers correspond to pages in the 1993 Program Technology Update where these project are described).

Similar technology is a low- $\mathrm{NO}_{\mathrm{x}}$ cell bumer retrofit (developed) demonstrated by $\mathrm{B} \& \mathrm{~W}$ on one of it own boilers (Project 7-42, Table 12). According to the project description the lower burner fires all fuel while the upper burner is used to supply the secondary air.

More complex but more effective measures are associated with reburning. The technology proves to be simpler and more efficient (60-70 percent of $\mathrm{NO}_{\mathrm{x}}$ reduction) when natural gas is used as reduction fuel (Project 7-44, 7-70, Table 12). Micronized coal reburning (Project 7-52, Table 12) and cyclone boiler reburning (Project 7-40, Table 12) are more difficult to realize and are less efficient. $\mathrm{NO}_{\mathrm{x}}$ emissions in this case are reduced by 50-60 percent. Application of reburning technology needs a $\$ 17-65 / \mathrm{kW}$ capital investment, reduces unit efficiency by about 0.25 percent, and increases operating cost by about 0.1 cent/kWh (Table 15).

CCTP includes some project using SCR technology for the control of $\mathrm{NO}_{\mathrm{x}}$ emissions (Project 7-50, 7-64, 7-68, Tables 12 and 14) and SNCR technology (Project 7-76, 7-72, Table 14).

In non-catalytic systems that use urea $50-70$ percent of the $\mathrm{NO}_{\mathrm{x}}$ are reduced with a capital cost of $\$ 5-20 / \mathrm{kW}$ and a cost of generation increased by $0.11-0.13 \mathrm{cent} / \mathrm{kWh}$ (Table 15).

The ammonia-based catalytic system can reduce 80-90 percent of $\mathrm{NO}_{\mathrm{x}}$ at a capital cost of $\$ 80-90 / \mathrm{kW}$ (combined with $\mathrm{SO}_{2}$ control, $\$ 250 / \mathrm{kW}$ ).

In implementing SCR systems, the technologies of both foreign (Project 7-50, 7-64) and 
domestic (Project 7-68, Table 14) companies were applied.

The data on various $\mathrm{NO}_{\mathbf{x}}$ control technologies are shown in Table 15.

Wet and wet/dry flue gas cleaning systems have been used for many years to reduce $\mathrm{SO}_{\mathbf{x}}$ emissions at U.S. TPSs. Limestone and lime are employed as sorbent with the final product (usually a mixture of $\mathrm{CaSO}_{3}$ and $\mathrm{CaSO}_{4}$ ), after additional oxidizing (neutralization) and mixing with ash, being dumped to disposal areas.

Under the CCTP some simplified $\mathrm{SO}_{\mathrm{x}}$ cleaning systems are being designed. Among them Project 7-66, 7-76, 7-70 are technologies that inject limestone and various grades of lime into the upper part of the furnace, and humidify the sorbent-containing flue gases in the gas duct to enhance sulfur capture.

To this group belong technologies of sorbent (lime) solution or slurry injection into the gas duct. In some cases the slurry is injected such that it is dispersed along the duct, as it is done in Project 7-56, Table 13. Besides the CCTP project, U.S.A. companies have developed many other simplified $\mathrm{SO}_{x}$ control systems: $\mathrm{E}^{-\mathrm{SO}_{x}}$ featured by using the entrance of the ESP as the location of the wet/dry reactor; LIDS, which inject a slurry of ash enriched with unused sorbent into the gas duct, etc.

Implementation of such systems requires relatively. small capital investment $(\$ 30-100 / \mathrm{kW})$. At considerable sorbent consumption rates their efficiency is $50-70$ percent maximum, while the cost of removed sulfur turns out to be rather high (\$350-700/t). The by-product of FGD are not commercial grade.

Realization of wet/dry sulfur removal in special reactors (Project 7-54, 7-58, Table 13) enables increased efficiency of up to $80-90$ percent and better sorbent utilization, but, of course, at a higher cost of the system.

Under Project 7-54 the technology of wet/dry $\mathrm{SO}_{\mathrm{x}}$ removal in a CFB with high particle concentration (from $460-1830 \mathrm{~kg} / \mathrm{m}^{3}$ ) has been developed. The concept is based on increased surface contact between the lime slurry and acid gases on the particle surface which becomes commensurable with the contact surface typical for wet $\mathrm{SO}_{x}$ control systems. In this case, heat and mass transfer are enhanced, injection of slurry is simplified, and - because of recirculation - lime utilization increases up to about 80 percent. Reaction in the CFB needs less time; $2-3$ seconds at a gas velocity of $6-6.5 \mathrm{~m} / \mathrm{s}$ as compared to $10-12$ seconds at 
$1.2-2 \mathrm{~m} / \mathrm{s}$ in conventional wet/dry reactors. It is important that the cleaning action of the fluidized particles in the reactor causes no deposit, and the temperatures can be lower than those in conventional wet/dry reactors. The cost of such a wet/dry sulfur removal system can be about 25 percent less, and the total expenditures - despite more expensive sorbent - 15 percent less than in the case of wet limestone FGD.

More efficient sulfur removal systems are required when using high sulfur coals where even 90 percent $\mathrm{SO}_{2}$ removal efficiency may be insufficient to meet environmental control requirement. The CCTP project include 2 advanced wet limestone FGD technologies of 95 percent efficiency (Project 7-60 and 7-62, Table 13). They are based on improved processes that employ cheap natural limestone as sorbent in minimum amount, operate close to the stoichiometric value, and produce commercial-grade gypsum. For these reasons, despite the complex nature, the high investment cost $(\$ 180-250 / \mathrm{kW})$, and decreasing of unit efficiency by about 1.5 percent, the cost of $1 \mathrm{t}$ of removed sulfur is competitive, and with high sulfur coals may be the cheapest technology.

Under Project 7-60, a wet limestone advanced FGD system with a scrubber suitable to clean gases from several boilers has been designed and installed at the Bailly TPS. It employs an advanced single-stage process based on an increased rate of straight-flow washing and better oxidation in the same scrubber to produce commercial-grade gypsum. It also employs an effluent evaporation system.

A jet-bubbling reactor has been designed for FGD at the Yates Plant Unit No. 1, a 100-MW unit firing high sulfur bituminous coal (Project 7-62).

The reactor with a 12.8-m diameter and height is made of fiberglass-reinforced plastic. The flue gas bubbling through the limestone slurry is accompanied by $\mathrm{SO}_{2}$ absorption, neutralization, gypsum crystallization and washing from the particulate. Air is also bubbled through the slurry oxidizing $\mathrm{CaSO}_{3}$ to $\mathrm{CaSO}_{4}$. Fiberglass-reinforced plastic is used to manufacture the wet flue gas duct, a $115-\mathrm{m}$ high stack, and 8.54-m diameter by 7.63-m high limestone slurry tank. Fiberglass plastic undergoes no corrosion/erosion, which is the case with the same element manufactured from stainless steel. Therefore, no preheating of wet cleaned gases is required to prevent condensation in the gas duct located downstream. Only 2 stages of the separator (mist eliminator) are installed past the absorber to remove water droplet entrained from the latter. Aerodynamic separation of the condensed moisture is provided in the stack throat. 
Several integrated $\mathrm{NO}_{x} / \mathrm{SO}_{2}$ emission control technologies are being designed in CCTP project.

Project 7-76 most completely utilized simplified technologies of $\mathrm{NO}_{\mathbf{x}} / \mathrm{SO}_{2}$ emission control. The base is a $100-\mathrm{MW}$ unit boiler using down-fired burners with over-fire air port in the bottom of the furnace. The boiler fires low-sulfur ( $\mathrm{S}=0.4$ percent) bituminous coal. To reduce $\mathrm{NO}_{x}$ formation low-NO $\mathrm{N}_{\mathbf{x}}$ burners and two-stage combustion is applied. For further $\mathrm{NO}_{x}$ reduction urea is injected at the furnace outlet. Sulfur is captured by Ca- and Na-based sorbent injected before economizer $\left(540^{\circ} \mathrm{C}\right)$ and air preheater $\left(315{ }^{\circ} \mathrm{C}\right)$.

The SNOX technology (Project 7-64, Table 14) is well known. It has been used for several years at a commercial 300-MW unit in Denmark. Flue gases are catalytically deeply cleaned of $\mathrm{NO}_{x} / \mathrm{SO}_{2}$ along with the production of saleable sulfuric acid. No data is available on the system's operational characteristics, cost, or the intention of Denmark electric utilities to apply this technology at any other TPS under construction in that country.

The efficiency and prospects for application of $\mathrm{SO}_{2} / \mathrm{NO}_{x}$, and, sometimes, ash emission control systems that are undoubtedly technically interesting, under Project 7-68, 7-72 and 7-74 (Table 14) are difficult to assess because only predesign data are available. They indicate only technical feasibility and the terms of implementation of the processes and the determination of the major equipment profile.

\subsection{Advanced Power Technologies Project}

The CCTP includes two project that use circulating fluidized-bed boiler unit.

At Nucla Station (Project 7-16) a 420-t/h CFB boiler with hot cyclones for fly ash separation has been constructed, tested in detail, and is now in operation. The boiler has been designed to fire 3 types of Western coals with sulfur content of $0.4-0.8,1.5$, and 0.5 percent. Limestone is in-bed injected for sulfur capture.

The final atmospheric fluidized-bed boiler project under the CCTP is Project 7-18 with a goal to design the largest U.S. boiler, a 227-MW unit capable of delivering 175 th of $4.3 \mathrm{MPa}$ process steam. The experience known to date has been accounted for in the project. The sulfur capture is scheduled at 92 percent. In addition to using state-of-the-art combustion measures, ammonia/urea will be injected into the gas duct running from the furnace to cyclones to reduce half of the in-furnace formed $\mathrm{NO}_{\mathrm{x}}$. Much attention has been paid to 
maintaining optimal boiler modes. The start of test is scheduled for the beginning of 1998 .

Under Project 7-32 a system of coal combustion in a slagging cyclone has been designed. Two cyclones with a total capacity of $50 \mathrm{MW}$ are planned to be installed at the Healy station in Alaska. The cyclone is in fact a horizontal water-cooled cylinder slightly inclined in the direction of the gas exit. It employs staged fuel and air feed and pulverized limestone injection to capture $\mathrm{SO}_{2}$. Further $\mathrm{SO}_{2}$ capture will be in the wet/dry cleaning system. The $\mathrm{CaO}$-containing fly ash removed in the baghouse is used to prepare the sprayed slurry.

As fuel, a mixture of 50 percent run-of-mine and 50 percent waste coal with high ash content and lower heating value is fired. To facilitate removal of the liquid slag, air fed to the cyclone is preheated by firing $25-40$ percent of the coal in the precombustor. Seventy to eighty percent of the fly ash is removed as molten slag. The hot gas containing the incomplete combustion product is directed to the furnace, and additional air is fed to the furnace for complete combustion. In such a system, $\mathrm{SO}_{2}$ emissions are reduced by more than 90 percent, maximum $\mathrm{NO}_{\mathrm{x}}$ emissions are $86 \mathrm{mg} / \mathrm{MJ}\left(220 \mathrm{mg} / \mathrm{m}^{3}\right)$, and maximum particulate emissions are $6.5 \mathrm{mg} / \mathrm{MJ}\left(16.5 \mathrm{mg} / \mathrm{m}^{3}\right)$.

The slagging horizontal cyclone combustor included in Project 7-98 is close in concept to the above design. It specific features are ceramic lining and wall cooling by secondary air, which enables the use of compact cyclones to retrofit various types of boilers while leaving their steam/water path unchanged. The design capacity of the cyclones is $6.74 \mathrm{MWt}$.

Formation of $\mathrm{NO}_{\mathrm{x}}$ in the cyclone combustors is reduced by oxygen-deficient combustion; for $\mathrm{SO}_{2}$ capture limestone is injected. The molten ash and the sorbent that captures the major amount of the coal sulfur are separated on the cyclone walls. Injection of additional amount of sorbent into the boiler duct increases the sulfur capture efficiency.

Under the CCTP, seven project that demonstrate IGCC plant are being developed. Some data on these project can be found in Tables 16 and 17. The total cost is about $\$ 3 \times 10^{9}$, including about $\$ 1 \times 10^{9}$ from the Federal budget.

Project 7-28 and 7-30 are based on the technology of coal-water slurry, entrained-flow, oxygen-blown gasification which has been commercially demonstrated.

At the Wabash River TPS (Project 7-30) a two-stage gasification of the slurry prepared from a 2.3 to 5.9 percent $S$ bituminous coal will be realized. The coal consumption will be 
$2,315 \mathrm{t} / \mathrm{d}(96.5 \mathrm{t} / \mathrm{h})$. In the first stage, gasification occurs creating molten ash which is removed as liquid slag from the gasifier lower part. No ash melting occurs in the second stage. The raw gas is cooled in heat exchangers and cleaned in the conventional lowtemperature system where particulate, $\mathrm{NH}_{3}$, and sulfur compounds are removed. Ceramic filters capture the fly ash and return it to the gasifier. The cleaned mean-calorie (medium Btu) gas is preheated with steam generated in the raw gas cooling system, and then fired in the GT combustor. Superheated HP steam is generated in the heat-recovery boiler downstream of the GT. Also, HP steam produced in the raw fuel gas cooling system is superheated there. Both steam streams are expanded in the steam turbine available at the existing TPS site.

This single-train gasification system will be the largest in the U.S.A.

The designed sulfur cleaning efficiency will be 98 percent, $\mathrm{NO}_{\mathrm{x}}$ reduction will amount to 90 percent, and $\mathrm{SO}_{2}$ emissions will be $<86 \mathrm{mg} / \mathrm{MJ}, \mathrm{NO}_{x}<43 \mathrm{mg} / \mathrm{MJ}$.

The Polk Power Station (Project 7-28) will use single-stage gasification of Illinois 6 and Pittburgh 8 bituminous coals having a sulfur content ranging from 2.5-3.5 percent. Two parallel desulfurization systems will be employed in the project: conventional lowtemperature and high-temperature in a moving bed of zinc titanate sorbent. To decrease $\mathrm{NO}_{\mathbf{x}}$ formation, the cleaned syngas will be mixed with nitrogen from the air separation plant. The design sulfur removal efficiency will be 96 percent ( 98 percent, for industrial plant), $\mathrm{NO}_{\mathrm{x}}$ will be reduced by 90 percent; and the emissions of $\mathrm{SO}_{2}$ will be $90 \mathrm{mg} / \mathrm{MJ}, \mathrm{NO}_{\mathrm{x}} 116 \mathrm{mg} / \mathrm{MJ}$.

The third CCP project (Project 7-20) using entrained-flow gasification is underway at the Springfield TPS. There, at $23 \mathrm{th}(550 \mathrm{t} / \mathrm{d})$ dry dust of Illinois 6 coal will be gasified in a two-stage air-blown gasifier with liquid slag removal at the first stage. The raw coal-derived gas temperature will be $1000{ }^{\circ} \mathrm{C}$ before being reduced to $540{ }^{\circ} \mathrm{C}$ in the gas cooler. At this temperature, the gas will be cleaned of coke particles; first in a cyclone, and then in a fines filter. The particles will be returned to the gasifier, and the gas will be directed to the desulfurization system with a zinc titanate moving bed. The sulfur removal efficiency will be 99 percent, and the $\mathrm{NO}_{x}$ will be reduced by 90 percent. The $\mathrm{SO}_{2}$ and $\mathrm{NO}_{x}$ emissions will be less than $43 \mathrm{mg} / \mathrm{MJ}$.

Fluidized-bed air-blown gasification of bituminous coals is underway according to Project 7-24 and 7-26. 
At the Piñon Pine Station (Project 7-24), $812 \mathrm{t} / \mathrm{d}(34 \mathrm{t} / \mathrm{h}$ ) of the Utah $0.5-0.9$ percent $\mathrm{S}$ crushed coal will be gasified. The limestone is also in-bed injected to capture the sulfur and to prevent the conversion of fuel nitrogen to $\mathrm{NH}_{3}$. The temperature of the raw coal-derived gas at the gasifier outlet is $925{ }^{\circ} \mathrm{C}$. The fly ash is separated in a cyclone and returned into the gasifier. The gas is cooled to $595^{\circ} \mathrm{C}$ and sulfur is additionally removed in an oxide metal bed. When sulfur is captured in the fluidized bed, $\mathrm{CaS}$ is formed which forms after oxidation, together with the fuel ash, agglomerated particles suitable to be disposed. The coal-derived gas is fine cleaned of particulate mater in ceramic filters. To reduce $\mathrm{NO}_{\mathbf{x}}$ formation steam is added to the cleaned coal-derived gas.

The design sulfur cleaning efficiency is 94 percent, and $\mathrm{NO}_{x}$ emissions will be reduced by 90 percent. The emissions of $\mathrm{SO}_{2}$ and $\mathrm{NO}_{x}$ will be $30 \mathrm{mg} / \mathrm{MJ}$.

Test are planned using West Virginia bituminous coal with $S=2-3$ percent.

An industrial CCP using the above gasification technology will be 43.7 percent efficient and ensure 98-99 percent cleaning of sulfur when high-sulfur coals are gasified. The emissions of $\mathrm{SO}_{2}$ will be below $19.5 \mathrm{mg} / \mathrm{MJ}$ and those of $\mathrm{NO}_{x}$ below $23 \mathrm{mg} / \mathrm{MJ}$.

At the Toms Creek Station (Project 7-26) a fluidized-bed system that will gasifiy 390-t/d (16.5-t/h) of coal will be realized. Using a calcium base sorbent, 90 percent of the coal sulfur is captured in the bed. The raw coal-derived gas will leave the gasifier at an outlet temperature of $980-1040^{\circ} \mathrm{C}$ and be cleaned of the fly ash in two stage cyclones. The gas is cooled to $540{ }^{\circ} \mathrm{C}$ and the remaining sulfur is removed in a zinc titanate fluidized-bed reactor. Particulates are removed by a ceramic filter. Sulfur removal efficiency is 99 percent, with emissions of $24 \mathrm{mg} / \mathrm{MJ} \mathrm{SO}_{2}$ and $39 \mathrm{mg} / \mathrm{MJ} \mathrm{NO} \mathrm{x}_{\mathrm{x}}$. The efficiency of the industrial $270-\mathrm{MW}$ CCP will be 44 percent.

Another gasification technology is being designed under Project 7-22 for the Camden TPS. Gasification of high-sulfur ( $S=3$ percent) bituminous coal from West Virginia will be done in an oxygen-blown, moving-bed reactor with liquid slag removal. The gasifier output will be $1,685 \mathrm{t} / \mathrm{d}(67.5 \mathrm{t} / \mathrm{h})$. The lump coal will be used and the fines will be briquetted.

The raw gas will be washed to reduce it's temperature and remove tars, oils, ammonia and particulate. Combustibles will be returned to the gasifier. Conventional low-temperature cleaning will remove 99 percent of the $S$. The cold-gas gasification efficiency will be 89 percent and the carbon conversion will be 99 percent. 
The clean syngas is mixed with nitrogen from the air separation plant and is preheated prior to being fed to the GT.

$\mathrm{SO}_{2}$ and $\mathrm{NO}_{\mathrm{x}}$ emissions will be less then 43 and $65 \mathrm{mg} / \mathrm{MJ}$ respectively $\left(\mathrm{NO}_{\mathrm{x}}\right.$ reduction will be 90 percent).

Part of the syngas, after additional cleaning and saturation with steam, will be used to feed a 2.5-MW electrochemical generator, based on the molten carbonate fuel cell, that will be integrated into the CCP circuit.

One more gasification project, Project 7-96, will be realized within CCTP. There the $2,910 \mathrm{t} / \mathrm{d}(121 \mathrm{t} / \mathrm{h})$ plant for direct reduction of iron ore without using coke will be integrated with the CCP circuit of $150 \mathrm{MWe}$. The process system includes an iron ore reduction fumace and the melter gasifier arranged below it. The capacity of gasifier is $2,550 \mathrm{t}$ of coal/d (106 t/h). It's purpose is gasifying coal and melting iron. A reducing gas is generated in the gasifier and the heat required for iron melting is released. The excess of coal-derived reduction gas exiting the fumace is cooled, cleaned, and compressed before firing in a GT.

Reduction of emissions by more than 85 percent is achieved through the capture of ore and coal sulfur in the reducing furnace with limestone injection under effective control of the process. Since no coke is required for iron production there is no environmental pollution resulting from it's production.

The combined process energy efficiency is 35 percent higher, compared with alternative processes, due to the better utilization of the coal's sensible heat, volatiles, and integration with CCP for production of electricity.

It is expected that the final $\mathrm{SO}_{2}$ and $\mathrm{NO}_{x}$ cleaning efficiency will be above 90 percent and at least 97 percent, respectively; $\mathrm{SO}_{2}$ emissions will be $10.5 \mathrm{mg} / \mathrm{MJ}$, and $\mathrm{NO}_{\mathrm{x}}$ emissions will be $5.2 \mathrm{mg} / \mathrm{MJ}$.

The general requirement for IGCC is the possible use of various kinds of coal. The gasification modules are being designed to provide flexibility when the CCP unit capacity is changed.

Project of CCP with various coal gasification and combustible gas cleaning technologies are at different stages of commercialization. 
Testing demo IGCC plants will start in 1995-1996. Oxygen-blown gasification systems with low-temperature gas cleaning are at a higher stage of development (Project 7-28, 7-30, 7-22) than other technologies under development. The specific cost of such systems will be $\$ 1500-2000 / \mathrm{kW}$ with LHV coal combustion efficiency at $40-42$ percent.

It is thought that the development and use of high-temperature gas cleaning systems will enable a future increase in the IGCC efficiency to 47 percent and create (the opportunity for) large commercial-size unit.

Along with higher efficiency typical for CCP with coal combustion in PFBC it is possible to exclude special de-SO $\mathrm{S}_{x}$ systems by adding limestone or dolomite to the coal. At moderate combustion temperature in the bed a small amount of $\mathrm{NO}_{\mathbf{x}}$ is formed. The by-product in this case is dry ash which can be utilized. A CCP using first generation bubbling PFBC has been realized at the Tidd Station in the U.S. (Project 7-14) and has operated for a long time. The 110-MW, $9 \mathrm{MPa}, 495{ }^{\circ} \mathrm{C}$ steam unit was redesigned by replacing the conventional boiler with a PFBC boiler fed with 1.3 MPa air from a 16-MW GT. The PFBC temperature is $860^{\circ} \mathrm{C}$, and the gas turbine inlet temperature is $830^{\circ} \mathrm{C}$. The steam turbine integrated with CCP operates at a reduced load of $55.9 \mathrm{MW}$. The CCP net capacity is $70.5 \mathrm{MW}$ at 34.5 percent efficiency.

According to the DOE CCTP, the same technology is being designed for the New Haven Station (Project 7-8), a 340-MW (net) PFBC. A GT of $75 \mathrm{MW}$ and a steam turbine with reheat are used there. The PFBC furnace pressure is increased to $1.6 \mathrm{MPa}$, the bed temperature is $870{ }^{\circ} \mathrm{C}$, and the CCP efficiency is 42.2 percent. The design $\mathrm{SO}_{2}$ capture and $\mathrm{NO}_{x}$ reduction are 9.5 percent and 80 percent respectively.

Also under the CCTP, a 70-MW CCP using a PCFB is being designed (Project 7-10) with a bed temperature and pressure of $870{ }^{\circ} \mathrm{C}$ and $1.2 \mathrm{MPa}$. The gas will be cleaned in a cyclone and a ceramic filter. The steam generated in the PCFB boiler will be expanded in an existing steam turbine. After redesigning, $\mathrm{CCP}$ efficiency will be 34.5 percent. Considering the parameters of the steam turbine, the efficiency will be increased by 15 percent.

With a 90 percent sulfur capture, $\mathrm{SO}_{2}$ emissions will be $300 \mathrm{mg} / \mathrm{MJ}$. Fly ash emissions will be $13 \mathrm{mg} / \mathrm{MJ}$, and $\mathrm{NO}_{\mathrm{x}}$ emissions will be reduced by 70 percent. The CCP start-up is scheduled for 1996. The project development (preliminary design) has been made for a 45 percent efficient commercial CCP with a PCFB boiler and additional topping combustor. 
Work is under way to design a second generation CCP with PFBC. To this end, the following is planned:

(I) replacement of the GT with a U.S.-made unit;

-(2) incorporation of a pyrolyzer and gas hot filter;

(3) increasing the GT inlet temperature.

The pyrolyzer ensures partial coal gasification producing a $925{ }^{\circ} \mathrm{C}$ combustible gas. The remaining carbon is removed as coke (char) and is fired in the PFBC combustor at $870^{\circ} \mathrm{C}$. The gases after the pyrolyzer and PFBC combustor are cleaned in high temperature filters. The GT inlet temperature is increased due to firing the combustible gas formed in the pyrolyzer in the top (topping) combustor.

The design validating test will be carried out at the Wilsonville, Alabama plant to be started in 1995. The test modules of the plant will be used to investigate heat transfer and refine the conditions for removing the total heat released in the PCFB. The bubbling-bed system is supposed to be used in the pyrolyzer. The demo plant employs a 4-MW GT. The top (topping) combustor is designed for an outlet temperature of $1290{ }^{\circ} \mathrm{C}$. Before the GT, the gases will be air cooled to $1080{ }^{\circ} \mathrm{C}$.

The plant is intended to play an important role in speeding up and simplifying the development and test of integrated GT clean coal technologies. After construction is completed, it will employ 5 modules. Apart from the advanced PFB combustor and GT, the system will use gasification in a transport reactor, several hot gas cleaning rigs, a fuel cell, and the associated gas treatment systems.

Within the framework of CCTP (Project 7-12), a 95-MW equivalent capacity, demo, CCP using a second generation PFBC is being designed and will be constructed at the Calvert City Station. It will employ a 38-MW GT, model W251B12, a 35-MW steam turbine, and produce $141 \mathrm{t} / \mathrm{h}$ of process steam.

In the GT with external, indirect coal combustion, the compressed air is preheated in the boiler to be further expanded in the GT. Coal combustion and flue gas cleaning are made close to atmospheric pressure as in conventional utility boilers. 
Predesign works dealt with this technology for 280-320-MW CCP proved a possible efficiency of 49.5-51 percent with a simple GT operating at a firing temperature of $1260-1370{ }^{\circ} \mathrm{C}$, and steam parameters of $16.4 \mathrm{MPa}, 593 / 593{ }^{\circ} \mathrm{C}$. In the boiler path in ceramic heat exchangers the air is heated up to $1090{ }^{\circ} \mathrm{C}$. Further temperature rise is obtained by fuel combustion in the additional combustor. The boiler furnace in the active burning zone is screened by wall superheaters.

Under the CCTP (Project 7-36) an externally fired combined-cycle demo system with a ceramic heat exchanger and hot-air operated GT will be constructed at Warren Station in Pennsylvania.

Work has been conducted in the U.S. on direct P.C. or coal-water slurry (CWS) combustion in the GT combustors for a long time. Some result are illustrated in Table 18. In all project, two-stage external combustion systems were used. At the first stage under fuel rich conditions carbon was gasified accompanied by the formation of low-calorie combustible gas which was cleaned between the first and second stages of fly ash, and - in the Allison and Westinghouse technologies - sulfur that was captured by sorbent injected at the first stage. According to the Solar technology, sorbent was injected at the second stage. In all cases at the second stage high amount of excess fresh air was added for full burnup of combustibles contained in the gas. Shown in the third column of Table 18 are the result of test conducted by the Allison with a full-size 4-MW GT. In large utility CCP with a coal-fired GT predesign, a net efficiency of $\mathbf{4 2}$ percent was calculated. Despite the promising result of the research, no construction of a demo plant is now planned.

\subsection{Result Obtained in CCTP Project}

Many project using low- $\mathrm{NO}_{\mathrm{x}}$ burners and reburning are either close to completion or are already completed with good result.

Under Project 7-46 with wall-fired burners and over-fire air at a nominal 500-MWe load, $\mathrm{NO}_{\mathrm{x}}$ emissions were reduced to $172 \mathrm{mg} / \mathrm{MJ}\left(440 \mathrm{mg} / \mathrm{m}^{3}\right)$. The emissions were found to vary insignificantly when the load dropped to $200 \mathrm{MW}$. When compared to the initial level of $546 \mathrm{mg} / \mathrm{MJ}\left(1400 \mathrm{mg} / \mathrm{m}^{3}\right), \mathrm{NO}_{\mathrm{x}}$ emissions were reduced by 68 percent, including 43 percent due to bumer retrofit and 25 percent because of staged combustion (over-fire). The test were conducted with bituminous coal of $28.6 \mathrm{MJ} / \mathrm{kg}$ (LHV) and $30.0 \mathrm{MJ} / \mathrm{kg}$ (HHV). The coal contained 10 percent ash, 33 percent volatiles, 72 percent carbon, 1.7 percent sulfur and 1.4 percent nitrogen. 
The amount of combustibles in the fly ash at 500-MW load increased from 5.5-8.0 percent despite considerably more fine coal dust.

\begin{tabular}{|c|c|c|}
\hline & Mesh 200 undersize,\% & Mesh 50 oversize,\% \\
\hline Initial state & 63 & 2.8 \\
\hline Advanced burners and over-fire air & 74 & 0.6 \\
\hline
\end{tabular}

This fact caused boiler efficiency to decrease by 0.25 percent. By increasing excess air, carbon loss can be decreased to the initial level. In this case, however, $\mathrm{NO}_{\mathrm{x}}$ emissions increase to $228 \mathrm{mg} / \mathrm{MJ}\left(589 \mathrm{mg} / \mathrm{m}^{3}\right)$.

Under project 7-42 cell burners were redesigned (see above). When firing different bituminous coals with $S=1.1$ percent, the average $\mathrm{NO}_{\mathrm{x}}$ concentration at boiler full load was found to drop from $500 \mathrm{mg} / \mathrm{MJ}\left(1280 \mathrm{mg} / \mathrm{m}^{3}\right)$ to $205-240 \mathrm{mg} / \mathrm{MJ}\left(530-615 \mathrm{mg} / \mathrm{m}^{3}\right), 55 \mathrm{percent}$ on average. The fly ash combustibles content was 1.1 percent and the carbon loss was 0.2 percent. The unit efficiency was not changed and no boiler corrosion rate change was observed.

Reduction of $\mathrm{NO}_{\mathrm{x}}$ formation by 37-48 percent at full-load was attained under Project 7-48 when testing a low-NO $\mathrm{N}_{\mathrm{x}}$ burner in a tangential-fired furnace with various combinations of burner rows, an additional air feed just above the row and separately above the burner area. The test were carried out firing various Eastern bituminous coals with $S=2.5-3.0$ percent.

The reconstruction and testing of boilers with the new low- $\mathrm{NO}_{\mathrm{x}}$ burners and reburning, using natural gas as a reducing fuel was made at 3 coal TPS employing different firing systems (Project 7-44, Table 12).

Basic result of test can be seen from the Table below: 


\begin{tabular}{|c|c|c|c|}
\hline & \multicolumn{3}{|c|}{ Location of test, furnace specifics } \\
\cline { 2 - 4 } & $\begin{array}{c}\text { Hanneping, } \\
\text { tangential-fired }\end{array}$ & $\begin{array}{c}\text { Lake Side, } \\
\text { cyclone }\end{array}$ & $\begin{array}{c}\text { Denver, wall- } \\
\text { fired burners }\end{array}$ \\
\hline Unit output, MWe & 71 & 33 & 172 \\
\hline $\mathrm{NO}_{\mathrm{x}}$ initial emission, & & & \\
\hline $\mathrm{mg} / \mathrm{MJ}$ & 320 & 435 & 310 \\
\hline $\mathrm{mg} / \mathrm{m}^{3}$ & 820 & 1115 & 795 \\
\hline $\mathrm{mg} / \mathrm{MJ}$ & & & 110 \\
\hline $\mathrm{mg} / \mathrm{m}^{3}$ & 105 & 150 & 285 \\
\hline $\mathrm{NO}_{\mathrm{x}}$ attained level, & 270 & 330 & 64 \\
\hline NO reduction, \% & 67 & 66 & $12.6(5-19)$ \\
\hline Share of natural gas, \% & 18 & $22.5(20-26)$ & 0.45 \\
\hline Reduction of boiler efficiency, \% & $0.3-1.1$ & 0.59 & 19.3 \\
\hline Over-fire air, \% & - & 28.7 & \\
\hline
\end{tabular}

Reburning, using coal dust as a reducing fuel, was implemented on a 100-MW unit cyclone boiler (Project 7-40) with the result that follow. 


\begin{tabular}{|c|c|c|}
\hline \multirow[t]{2}{*}{ Quantity } & \multicolumn{2}{|c|}{ Coal Grade } \\
\hline & $\begin{array}{l}\text { Lamar bituminous, } \\
\qquad S=1.8 \%\end{array}$ & $\begin{array}{l}\text { Powder River Basin } \\
\text { subbituminous coal, } \\
\qquad \mathrm{S}=0.6 \%\end{array}$ \\
\hline $\mathrm{NO}_{\mathrm{x}}$ initial emissions; & & \\
\hline $\mathrm{mg} / \mathrm{MJ}$ & 505 & 445 \\
\hline $\mathrm{mg} / \mathrm{m}^{3}$ & 1290 & 1140 \\
\hline $\mathrm{NO}_{\mathrm{x}}$ attained level, & & \\
\hline $\mathrm{mg} / \mathrm{MJ}$ & 230 & 165 \\
\hline $\mathrm{mg} / \mathrm{m}^{3}$ & 590 & 420 \\
\hline . $\quad \mathrm{NO}_{\mathbf{x}}$ reduction, $\%$ & 55 & 63 \\
\hline Carbon loss, \% & 1.5 & 0.3 \\
\hline Increase of carbon loss, $\%$ & 0.1 & 0.0 \\
\hline
\end{tabular}

In Project 7-56, 50 percent $\mathrm{SO}_{2}$ capture was attained on 73.5-MW unit boiler firing bituminous coal with $\mathrm{S}=1.5-2.5$ percent when sorbent - slurry of hydrated calcite and pressurized hydrated dolomite limes - were sprayed in the gas duct.

The evaporation of droplet and the absorption of $\mathrm{SO}_{2}$ were completed in $2 \mathrm{~s}$. No deposit were observed in the duct. The system operated reliably and it is easily automated.

When testing a simplified wet/dry $\mathrm{SO}_{2}$ control system under Project 7-66, LIMB-Coolside, 61 percent of $\mathrm{SO}_{2}$ capture was reached in LIMB system on a 105-MW unit firing 3.8 percent $\mathrm{S}$ coal using lignolime as sorbent. In the Coolside process using hydrated lime at a $\mathrm{Ca} / \mathrm{S}=2.0$ and a $\mathrm{Na} / \mathrm{Ca}=0.2,70$ percent $\mathrm{SO}_{2}$ capture was reached at $11^{\circ} \mathrm{C}$ of the approach-to-saturation temperature.

In $\mathrm{SO}_{2}$ control system testing with LIFAC technology (Project 7-58) 20-30 percent $\mathrm{SO}_{2}$ was captured using limestone injection into the top of a $60-\mathrm{MW}$ boiler furnace. Another 40-55 percent $\mathrm{SO}_{2}$ was captured in the activation reactor where flue gas containing $\mathrm{CaO}$ - the limestone calcination product - was humidified with injected water. Thus, the overall $\mathrm{SO}_{2}$ cleaning efficiency reached 80-85 percent. To recover the flume opacity above the stack, the leaving gas temperature, which was reduced since $\mathrm{SO}_{2}$ control installation, was increased to 
$93^{\circ} \mathrm{C}$ by mixing the leaving gas with a small amount of hot gas.

Using technological methods in Project 7-76, $\mathrm{NO}_{\mathrm{x}}$ emissions were reduced from $665 \mathrm{mg} / \mathrm{MJ}$ $\left(1700 \mathrm{mg} / \mathrm{m}^{3}\right)$ to $240 \mathrm{mg} / \mathrm{MJ}\left(615 \mathrm{mg} / \mathrm{m}^{3}\right)$, i.e., by 63-69 percent without increased carbon losses. With in-furnace urea injection, $\mathrm{NO}_{\mathrm{x}}$ emissions were further decreased to $128 \mathrm{mg} / \mathrm{MJ}$ $\left(330 \mathrm{mg} / \mathrm{m}^{3}\right)$, that is another 40 percent with an $\mathrm{NH}_{3} / \mathrm{NO}_{\mathrm{x}}=0.85$. The overall $\mathrm{NO}_{\mathrm{x}}$ reduction was greater.than 80 percent. Urea injection causes $\mathrm{N}_{2} \mathrm{O}$ formation in the amount of 20-35 percent of the total reduced $\mathrm{NO}_{\mathrm{x}}$. With the injection of pretreated urea to yield $\mathrm{NH}_{3}$ only 3-10 percent $\mathrm{N}_{2} \mathrm{O}$ was formed.

With in-duct injection of dry calcium hydroxide $(\mathrm{Ca} / \mathrm{S}=1.75-2.0)$ followed by gas humidification to $16.5{ }^{\circ} \mathrm{C}$ of the approach-to-saturation temperature not more than 25 percent $\mathrm{S}$ was captured. Even in this case hard to remove deposit were formed in the fabric filter.

Injection of dry sodium sesquicarbonate and bicarbonate before the air heater in the ratio of $\mathrm{Na} / \mathrm{S}=1.2-1.5$ enables an 80-89 percent $\mathrm{SO}_{2}$ capture to be obtained. Despite formation of 20-35 ppm of $\mathrm{NO}_{2}$ a colored plume above the stack was not observed.

As for Project 7-54, good result were reported in testing wet/dry $\mathrm{SO}_{2}$ removal in a CFB reactor with a high concentration of particles.

The reactor with an equivalent capacity of $10 \mathrm{MWe}$ was constructed on the gas duct bypass of the 150-MW unit boiler. In demonstration test on 2.7 percent $S$ (in some periods up to 3.5 percent $\mathrm{S}$ ) and 0.12 percent $\mathrm{Cl}$ coal the system operated with an average $\mathrm{SO}_{2}$ reduction of 90-91 percent at a molar ratio of $\mathrm{Ca}(\mathrm{OH})_{2} / \mathrm{SO}_{2}=1.40-1.45$ and an approach-to-saturation temperature of $10^{\circ} \mathrm{C}$. Previously the system operated normally without deposit formation at an approach-to-saturation temperature of $2.8{ }^{\circ} \mathrm{C}$ using coal with low $\mathrm{Cl}$ content, and at 10.0-12.8 ${ }^{\circ} \mathrm{C}$ of the approach-to-saturation temperature with $\mathrm{Cl}$ content no more than 0.3 percent. With such approach-to-saturation temperature values and $\mathrm{Ca}(\mathrm{OH})_{2} / \mathrm{SO}_{2}=1.4$, $\mathrm{SO}_{2}$ capture was $98-100$ percent in preliminary test. The effect of operating conditions on $\mathrm{SO}_{2}$ reduction can be seen below. 


\begin{tabular}{|c|c|c|c|}
\hline $\begin{array}{l}\text { A p proach-to-s a t u ration } \\
\text { temperature, }{ }^{\circ} \mathrm{C}\end{array}$ & 4.4 & 10.0 & 10.0 \\
\hline $\mathrm{Coal} \mathrm{Cl} \mathrm{content,} \mathrm{\%}$ & 0.004 & 0.04 & 0.12 \\
\hline $\mathrm{SO}_{2}$ removal efficiency, \%: & & & \\
\hline at $\mathrm{Ca}(\mathrm{OH})_{2} / \mathrm{SO}_{2}=1.0$ & $79.5(72-92)$ & $70(67-77)$ & $84(78-95)$ \\
\hline at $\mathrm{Ca}(\mathrm{OH})_{2} / \mathrm{SO}_{2}=1.3$ & $94.0(88-99)$ & $85(78-92)$ & $93(90-95)$ \\
\hline
\end{tabular}

The advanced wet $\mathrm{SO}_{2}$ control systems have been in operation for years (Project 7-60, 7-62).

The average system efficiency at the Baily TPS 500-MW unit (Project 7-60) firing bituminous coal with 2.0-4.5 percent $S$ content was 94 percent. During special test over 98 percent efficiency was attained. With regular unit operation $\mathrm{SO}_{2}$ emissions were $165 \mathrm{mg} / \mathrm{MJ}$ $\left(420 \mathrm{mg} / \mathrm{m}^{3}\right)$. Auxiliary power requirement were $5.3 \mathrm{MW}$ ( $<0.9$ percent), and the gas path pressure drop was about $800 \mathrm{~Pa}$. The $\mathrm{SO}_{2}$ control system operated reliably. The 2-year average availability factor of the whole complex was close to unity ( 99.996 percent). During that period, $121,300 \mathrm{t}$ of $\mathrm{SO}_{2}$ was removed, $198,800 \mathrm{t}$ of limestone was consumed, and $356,000 t$ of 97.2 percent quality gypsum was produced.

The average water flow rate was $355 \mathrm{~m}^{3} / \mathrm{h}$ with an average effluent discharged at $18.4 \mathrm{~m}^{3} / \mathrm{h}$. Waste waters contained 4,560 ppm chlorides, $<2,500 \mathrm{ppm}$ sulfates, $19 \mathrm{ppm}$ fluorides, $14.1 \mathrm{~g} / \mathrm{m}^{3}$ dissolved solids and had a $\mathrm{pH}=8-9$.

The $\mathrm{SO}_{2}$ control system using a bubbling reactor (Project 7-62) was put into operation in March 1993. It enabled 98.7 percent $S$ capture, collected 90 percent of particles $>1$ micron and up to 50 percent, of particles $<1$ micron that were left after cleaning by a 99 percent efficiency ESP, and utilization of over 97 percent of the limestone when operating at low $\mathrm{pH}$ value. The $\mathrm{SO}_{2}$ removal system final product is saleable gypsum produced at rate of $7 \mathrm{th}$. The power consumed by the $\mathrm{SO}_{2}$ control system constitutes about 1.5 percent of the unit output with a possible reduction by process optimization. No liquid deposition from the flume above the stack was observed even at 100 percent air humidity. During the first 5,000 operating hours the system availability was 98 percent.

The 35-MW equivalent capacity system of flue gas cleaning was installed as a bypass (slipstream) on a boiler firing coal with $S=3.4$ percent. The system used a baghouse to remove particulate matter and $\mathrm{SNOX}$ technology to catalytically remove $\mathrm{SO}_{2}$ and $\mathrm{NO}_{x}$. The 
flue gas cleaning efficiency of $\mathrm{SO}_{2}, \mathrm{NO}_{x}$, and particulate matter was 96 percent, 94 percent and 99.9 percent respectively. The system produced $25.5 \mathrm{t} / \mathrm{d}$ of 93 percent sulfuric acid with no solid wastes. The majority ( 99 percent) of flue gas toxics were removed in the SNOX process itelf, with or without the baghouse The system has been in operation for $5,700 \mathrm{hrs}$.

When testing a 5-MW equivalent capacity SNRB system (Project 7-68) the following result were obtained using real combustion gases of bituminous coal with $S=3.4$ percent.

\begin{tabular}{|l|c|c|c|}
\hline Sorbent & Ratio & Temperature, ${ }^{\circ} \mathrm{C}$ & Sulfur Capture,\% \\
\hline $\begin{array}{l}\text { Commercial hydrated } \\
\text { lime }\end{array}$ & $\mathrm{Ca} / \mathrm{S}=2.0$ & $430-470$ & 80 \\
\hline Sugar hydrated lime & $\mathrm{Ca} / \mathrm{S}=2.0$ & $430-470$ & 90 \\
\hline Sodium bicarbonate & $\mathrm{Na} / \mathrm{S}=1.0$ & 220 & 80 \\
\hline
\end{tabular}

At $430-470{ }^{\circ} \mathrm{C}, 90$ percent $\mathrm{NO}_{\mathrm{x}}$ reduction was attained with zeolite catalyst and ammonia injection providing an $\mathrm{NH}_{3} / \mathrm{NO}_{\mathrm{x}}=0.9$. Particulate removal by the baghouse was 99.89 percent.

Out of the advanced electric power generation technologies, the PFB coal combustion CCP project is the most mature (Project 7-14, Table 16).

The CCP test began at the end of 1990. Since that time comprehensive investigations have been conducted. Problems were detected and eliminated with preparation, feed, and distribution of the coal-water paste used as fuel; uniform in-bed coal combustion without impermissible ash agglomeration; ensuring nominal steam capacity by increasing the surface of in-bed tube bundles; and cleaning combustion product of fly ash in cyclones and removal of separated ash. The modifications and repairs to restore operability after damages took time. Ultimately the CCP total operating time by mid-1994 was $7,880 \mathrm{hrs}$.

When assessing CCP availability one should take into account that the plant had been designed without backup systems and component which were the practice with industrial (commercial) unit. It is also important to note that $\mathrm{CCP}$ availability increased constantly with operational and test experience.

CCP featured good ecological characteristics. At full load and a $3.2 \mathrm{~m}$ high bed a 90 percent $\mathrm{S}$ capture was obtained at a $\mathrm{Ca} / \mathrm{S}=1.15-1.35$, and 95 percent $\mathrm{S}$ capture at a 
$\mathrm{Ca} / \mathrm{S}=1.5-1.8 . \quad \mathrm{NO}_{\mathbf{x}}$ emissions were $65-77 \mathrm{mg} / \mathrm{MJ}$.

Considering the experience obtained in mastering similar plant in Sweden and Spain, the PFBC technology can be considered ready for commercial application.

Project 7-16 is less complicated and also relates to the same group. The Nucla Station CFB boiler designed under this project was tested during 15,700 hrs firing various coals with $\mathrm{S}=0.4-0.8$ and 1.4-1.8 percent. At bed temperature of $880^{\circ} \mathrm{C}$, the following result were obtained:

$\begin{array}{ccc}\text { Ca/S Ratio } & 1.5 & 4.0 \\ \text { Sulfur Capture, \% } & 70.0 & 95.0\end{array}$

$\mathrm{NO}_{\mathrm{x}}$ emissions were $<145 \mathrm{mg} / \mathrm{MJ}\left(375 \mathrm{mg} / \mathrm{m}^{3}\right)$ with $77 \mathrm{mg} / \mathrm{MJ}\left(200 \mathrm{mg} / \mathrm{m}^{3}\right)$ on the average, and coal burnup was between $96.9-98.9$ percent. The presence of combustibles in the fly ash was evidence of incomplete combustion: only a small fraction of it is attributed to combustibles in the bottom ash and the flue gas $\mathrm{CO}$. The boiler efficiency was . 85.6-88.6 percent.

The new development for power generation are advanced cyclone combustors enabling radical reduction of $\mathrm{SO}_{2}$ and $\mathrm{NO}_{x}$. Such a cyclone (Project 7-98) operated on an industrial boiler under heat loads from 5.57-1.76 MW. It was tested during 900 hrs firing 8 various bituminous coals containing 19-37 percent volatiles and 1.0-3.3 percent sulfur. When limestone was used in the cyclone as sorbent in the ratio of $\mathrm{Ca} / \mathrm{S}=2.0$, up to 58 percent $\mathrm{S}$ capture was observed. It increased reaching 80 percent with sorbent addition in the boiler furnace. $\mathrm{NO}_{x}$ emissions were $160-184 \mathrm{ppm}\left(130-150 \mathrm{mg} / \mathrm{MJ}, 330-380 \mathrm{mg} / \mathrm{m}^{3}\right)$. Removed from the cyclone combustor as liquid slag were 55-90 percent of the ash and sorbent. The inert slag is a waste product. The combustion efficiency was $>99$ percent. 


\section{REDUCTION OF COAL TPS ENVIRONMENTAL IMPACT IN RUSSIA}

\subsection{Coal used at Russian TPS}

\subsubsection{General}

Russia possesses rich coal resources. The largest and most economically important of these are the Kuznetsk (Kuzn.) and Kansk-Achinsk (K-A) coal fields located in the southern part of Central Siberia. The production of coal now amount to about $270 \times 10^{6} \mathrm{t} / \mathrm{y}$.

In the European part of the country much coal is produced in the south, in the Eastern Donbass (Donb.) and to the north, in the Pechora (Pech.) coal fields. Production of the expensive and low-grade brown coals found near Moscow is rapidly decreasing.

There are many coal fields covering the (rather high) demands of the nearby regions.

A large amount of Ekibastuz (Ekib) coal produced in Kazakhstan is fired in Russian TPS.

The quantities and properties of coal fired in Russian TPS are illustrated in Table 19 [3].

Coal production conditions are most favorable in the K-A field, where large, horizontal seams, tens of $\mathrm{ms}$ thick, are located near the surface. The field is in an easily-accessible area with acceptable climatic conditions. The coal is produced by the open-cast (strip-mining) method at rather low cost.

The geological conditions in the highly-developed Kuzn field are now rather complex. The industry environmental impact here is high in many areas and the infrastructure is inadequate.

In the European part of the country the coal is mined underground which makes it cost very high. The geological conditions of the heavily mined areas (Eastern Donb and the Moscow area fields) are unfavorable. The Pechora coal field is located in a severe climatic area.

The Eastem regions of the country supply mostly low-grade, high-moisture, and high-ash local coals to be fired at power stations. Many old coal fields are exhausted and vast territories are energy-deficient. Coal will continue to plat an important role for the Russian power industry in the near future. The direction and specifics of the evolution of the coal industry in Russia are briefly discussed in Section 3. 


\subsubsection{Characteristics of Bituminous Coals}

Russia mostly uses the Kuzn bituminous coals from the Southern Part of Central Siberia. These high-grade, low-sulfur coals are adaptable for transport over large distances. Coals of various petrographic composition and degrees of carbonization are used to fire utility boilers. The properties of these coals are given in Table 20 wherein LF stands for long-flame, $G$ denotes gas-coals, WS designates weakly sintering, L means lean and A - anthracite. Wider limit of variation of some properties - maximum moisture content up to 18-21 percent, lean coal volatile matter content of 5.5-14 percent, heating value of $16.5-27.7 \mathrm{MJ} / \mathrm{kg}$ are characteristic of open-cut produced coals of respective grades [26].

Besides the graded coals, TPS are supplied with various by-product and slurries from coalbeneficiation operations. The properties of such materials vary widely (refer to the last column of Table 20 ).

In terms of geology and available transportation asset, production of these superior coals could be significantly increased. However, the region in which they occur is saturated with various large, basic industries such as coal, metallurgy, chemicals and others. This has strained the local infrastructure to the point that increasing coal output substantially would require large capital investment.

Despite all this, the Kuzn coal field is still a major coal base of Russia and the coals from this field are used at many existing TPS, including those in the European part of the country. This coal is fired at a great number of cogeneration and condensing power plant employing 150- and 200-MW subcritical unit, and also at TPS with 300-MW supercritical unit. 800-MW unit Installed at the Perm, and designed to fire Kuzn coal are also operated on natural gas.

Characteristics of bituminous coals from other fields in Russia are shown in Table 21.

Only a small area of the Donetk coal field remains in the Rostov region (the south of the European part of the country) of Russia. The power industry uses mostly the high-sulfur lean coals and anthracite culm (AC) produced there.

The Pechora coal field is located in the northern part of European Russia. Inta coals, produced there, have a high sulfur and high ash content which is difficult to reduce by beneficiation. 
In both coal fields the coal is mined underground at high cost.

The coal from the Ekib field in northem Kazakhstan, widely used at Russian TPS, is weakly sintering mostly because of the high content of mineral matter. In view of seam peculiarities, the Ekib coal is mostly produced in bulk where the ash content reaches 55 percent.

Twenty to thirty percent of the ash of the Kuzn, Donetk, Pechora and Neryungri coals consist of the basic oxides: $\mathrm{Fe}_{2} \mathrm{O}_{3}, \mathrm{CaO}, \mathrm{mgO}, \mathrm{K}_{2} \mathrm{O}, \mathrm{Na}_{2} \mathrm{O}$ with the major share of $\mathrm{Fe}_{2} \mathrm{O}_{3}$. Because of that, the ash fusion temperature for Kuzn coals is in the range of $975-1,050^{\circ} \mathrm{C}$. It was found to decrease with increasing concentration of alkali element $\mathrm{Na}$ and $\mathrm{K}$ in the ash [27].

In firing most Kuzn coals, no substances are formed or selectively released that form stubbom deposit on heating surfaces because the coals are weakly sintering.

Donetk coals have characteristically high sulfur content, up to 70 percent of which is in the form of pyrites.

Low-reaction Donetsk coals are usually fired in wet-bottom furnaces and at high temperatures which cause the melting out and averaging of the entire fly ash. That is why the heating surface deposit are friable; even at the slagging temperatures given above self-removal of deposit is observed.

In rare cases, when firing Donetsk coals in dry-bottom furnaces, a dense layer of primary deposit with a concentration of $\mathrm{Fe}_{2} \mathrm{O}_{3}$ up to 40 percent is formed on tubes of platens and on the first rows of the convective superheater.

\subsubsection{Characteristics of Brown Coals}

The brown coals play a rather important role in the structure of fuel supply to Russian TPS. Out of about $150 \times 10^{6} \mathrm{t}$ of coals fired at TPS in 1993, the share of brown coals was about 50 percent (Table 19). The brown-coal fields are mostly located in Siberia and the Far East. The largest is the K-A field located in the southern Part of the Krasnoyarsk region. It is a unique natural phenomenon due to the size of the coal deposit and structure of it's coal seams. Of the 19 fields in the K-A basin that have been explored, three seams are currently being developed; Nazarovo, Berezovo and Borodinsk with a total production capacity of $58 \times 10^{6} \mathrm{t} / \mathrm{y}$. 
K-A coals have good firing and ecological characteristics: ash content $4.0-16$ percent, sulfur content $0.3-0.4$ percent, heating value 11.8-15.6 MJ/kg, and volatile yield 47-48 percent.

The K-A coal ash chemical composition is illustrated in Table 22 showing high (up to 42 percent) $\mathrm{CaO}$ content, and an increased content of $\mathrm{Na}$ and $\mathrm{K}$ oxides [27].

Brown coals used for power generation in eastern Siberia and the Far East differ from K-A coals both in firing properties (Table 19) and coal ash characteristics (Table 22).

In the European part of Russia, brown coals are mostly produced in the near-Moscow coal field. However, because of the high cost of mining and the low quality of these coals ( $S=2.3-2.5$ percent, $A=35-38$ percent, $W=30$ percent, $L H V=7-9 \mathrm{MJ} / \mathrm{kg}$ ) their use for power generation is decreasing.

The open-cut produced K-A coals are the cheapest and their increased use for power generation is an important economic goal. Production of these coals can be increased up to $80-130 \times 10^{6} \mathrm{t} / \mathrm{y}$ as long as the country's economy will improve.

Despite the available positive experience of transporting considerable amount of K-A coals by rail (up to $1.5 \times 10^{6} \mathrm{t}$ ) to TPS and storing it in open piles for a year and longer, more efficient long-distance transport of K-A coal-derived product are under consideration in order to reduce transportation cost on-site processing.

Among such possibilities are:

- preparation of the required coal dust at central pulverizing plant;

- preparation of crushed coal to be used in CFB boilers;

- production of coal briquettes;

- preparation of coal-water slurries;

- various kinds of pyrolysis to obtain semi-coke and liquid fuel.

Based on performance characteristics and feasibility by the year 2005, the first priority is the production of coal briquettes. It will enable reduction of cost for transport and services for 
coal storage, increase the reliability of fuel handling and pulverizing systems, and reduce environmental impact.

\subsection{Power and Environment Protection Technologies in Use}

Conventional bituminous coal-fired dry- and wet-bottom boilers are available.

Kuzn, Pech, and Yuzhno-Yakutk coals are close in their physical/chemical characteristics and are almost consistent with bituminous steam coal standards adopted for the World Market.

Ekib coals have a high ash content, are highly abrasive, non-slagging, and explosion-proof.

Donetsk AC are characteristically of very low reactivity (volatile yield of 4 percent); and are difficult to fire even with liquid slag removal.

The peculiarities of firing brown K-A coals and cleaning the flue gases formed result from the properties of these coals, which feature a high volatile yield, high reactivity, and a tendency to intensively slag boiler heating surfaces. They also readily self-ignite in storage, and the dust is explosive.

The history of using K-A coals goes back to firing Nazarovo and Irsha-Borodinsk coals in 320-500 t/h dry- and wet-bottom boilers.

The basic problems when firing the above coals are the accelerated slagging of furnace waterwalls and the impaired removal of liquid slag due to varying coal properties (when various-seam coals are supplied) and ash content. To overcome these problems, pilot boilers have been designed using special firing systems. These are briefly described in Section 2. Though they have been investigated in detail and numerous modifications of their component have taken place, the boilers have not found further application.

In view of the available commercial experience and the result of testing $\mathrm{K}-\mathrm{A}$ and other brown coals from the eastern fields, the most suitable combustion is a low-temperature one (below $1,200-1,300^{\circ} \mathrm{C}$ ) combined with gas drying and ballasting of the flame with combustion product. This has been implemented with the simultaneous modification of the modes and design of the tangential-fired furnaces with straight-flow burners on the new E-500 and P-67 boilers (see Section 2). 
The experience with firing the most slagging Berezovo coal in the E-500 and P-67 boilers showed that the furnace temperature level should not exceed $1,300^{\circ} \mathrm{C}$ to prevent quick slagging $[28,29,37]$.

The firing process can be improved by using more uniform coal dust, uniform flow of air and recirculated gases over burner tiers and channels, intensifying the fuel ignition, reducing the active burning zone temperature by increasing swirl in the upper part of the furnace chamber, and increasing to $40-45$ percent the amount of recirculated gas to these zones.

When bituminous coal ash contacts water no hard deposit are formed. This makes possible the wide application of wet ash collectors and hydraulic ash removal systems at old TPS firing Kuzn coals in boillers producing up to $670 \mathrm{t}$ steam $/ \mathrm{h}(186 \mathrm{~kg} / \mathrm{s})$. The above systems are also installed at AC and Ekib coal-fired boilers, with reference to the latter up to 500-MW unit. However, these systems are not sufficiently effective on ash separation and provide problems with further ash utilization. At newly installed bituminous coal-fired boilers of up to $1,000 \mathrm{t} / \mathrm{h}$ and more of fly ash is caught by ESP. When these power unit were designed ESP efficiency at 90-96 percent had been thought quite sufficient and an ESP of limited size with up to $3 \mathrm{~m} / \mathrm{s}$ gas velocity - economically reasonable.

The Ekib coal-fired 500-MW unit employ two-stage ash removal systems with a wet venturi scrubber being installed as the first stage and an ESP as the second stage, with an overall efficiency of 99.5 percent [28].

The K-A coal-fired TPS are now equipped with two types of ash collectors - multicyclones (66 percent) and ESP ( 34 percent). The fly ash removal in multicyclones is 92 percent maximum, while that in an ESP is 94-97.5 percent and depends on their type and size (generally, they fail to provide for the required residence time) and the boiler outlet temperature (often at $160-180^{\circ} \mathrm{C}$ ). These figures cannot be considered satisfactory.

In retrofitting/repowering existing and constructing new TPS upgraded ESP and baghouse filters will be applied to ensure the particulate matter emissions at $50-100 \mathrm{mg} / \mathrm{m}^{3}$ or below. Now in Russia a new type of ESP with a $460 \mathrm{~mm}$ electrode spacing has been mastered. It will be equipped with a variable current supply, automatic control and monitoring, and a pneumatic fly ash discharge from the hoppers.

The fly ash of low-sulfur Kuzn and Neryungri coals, and, particularly, of Ekib coals is of increased electrical resistivity. This may impair ESP operation and reduce the collection effi- 
ciency. In many cases, especially in retrofitting/repowering of existing TPS which lack space.. to install additional ESP fields or to extend the ESP area, flue gas conditioning at the ESP inlet is advantageous. Conditioning includes temperature reduction (which may also increase fuel utilization), using chemical additives (for example, $\mathrm{SO}_{3}$ ) or electromagnetic radiation which transforms lower $\mathrm{SO}_{\mathrm{x}}$ and $\mathrm{NO}_{\mathrm{x}}$ to higher oxides.

At some TPS by using simple flue gas conditioning before ESP (for example, reducing the temperature by injection of water-treatment plant salted effluent) fly ash emissions were decreased by $2-3$ times.

Fabric filters are attractive as a means of fly ash collection, but there is practically no operating experience with them in Russia. In this connection, the risk exist that with the high ash content (up to 25-35 percent) of many steam bituminous coals, the use of the fabric filter may entail difficulties or be inefficient.

Small-capacity demonstration fabric filters have been in successful operation with a K-A coalfired boiler for some years. Baghouse filters in sizes of $110,000,280,000$, and $940,000 \mathrm{~m}^{3} / \mathrm{h}$ have been made commercially available. They are employed in the metallurgical industry. A project is under way to install baghouse filters on the $500-\mathrm{t} / \mathrm{h} \mathrm{K}-\mathrm{A}$ coal-fired industrial boiler at the Minusinsk cogeneration plant.

In cases where it is profitable to keep a wet ash collection system and increase scrubber efficiency by using a higher spray rate, or by applying emulsifiers with a high rate of ash removal, it seems reasonable to use them to collect part of the $\mathrm{SO}_{2}$ contained in the flue gases. Experience indicates that $\mathrm{SO}_{2}$ reduction in these cases can be 50-70 percent.

The increased ash collection efficiency and reduction of particulate matter emissions up to $<50 \mathrm{mg} / \mathrm{m}^{3}$, which is technically feasible, also solves the problem of heavy metals and toxic product of incomplete combustion, which emissions are not regulated now.

Kuzn and Pech coals contain of 2.1-2.7 percent fixed nitrogen. High flame temperatures are required to ensure the complete combustion of the above and other bituminous coals with a moderate volatile yield. These circumstances facilitate $\mathrm{NO}_{x}$ formation in firing bituminous coals and make it difficult to attain the environmental requirement through technological methods only. Nevertheless, application at existing boilers (including wet-bottom boilers) of various methods capable of improving combustion (feed of coal dust of high concentrations, use of special burners, stage combustion) enabled $\mathrm{NO}_{x}$ reduction of up to 
$450-600 \mathrm{mg} / \mathrm{m}^{3}[28-32]$.

At low-temperature, combustion of brown coals, and $\mathrm{K}-\mathrm{A}$ coals in particular, $\mathrm{NO}_{\mathrm{x}}$ are primarily formed from the fuel nitrogen compounds. Theses compounds during volatile yield and firing can be converted to $\mathrm{NO}$ or $\mathrm{N}_{2}$ depending on the conditions.

In firing slagging coals, care is needed in the application of known firing methods for $\mathrm{NO}_{\mathbf{x}}$ suppression.

The boiler test showed that $\mathrm{NO}_{\mathrm{x}}$ concentrations could be reduced to $200-350 \mathrm{mg} / \mathrm{m}^{3}$ simply by decreasing excess air (SR). However, in this case, starting from a certain SR value, slagging of waterwalls was found to be accelerated. Boiler operation at minimum excess air is an urgent problem. The solution of the problem could be facilitated by mode optimizing with respect to the slagging and $\mathrm{NO}_{\mathbf{x}}$ formation, automatic control of furnace processes (flows of coal dust, air, recirculation gases), use of finer coal dust particles, and better waterwall cleaning.

Work is under way to modernize burners through the optimization of velocities of coal-air mixtures, secondary air and recirculation gases, stream outlet angles in horizontal and vertical planes, etc. Of interest is the application of bottom burners to fire high-reactivity, low-ash, strongly-slagging coals that make the flame longer (burning start at the furnace bottom) and move the flame from the furnace walls.

Simplified reburning of brown coals was implemented at $270-\mathrm{t} / \mathrm{h}$ and $420-\mathrm{t} / \mathrm{h}$ boilers at the Irkutk cogeneration plant. Both boilers have tangential-fired, dry-bottom furnaces with a twotier arrangement of straight-flow burners. The upper-tier burners operated at $\mathrm{SR}<1.0$, where the air required for complete combustion was fed via overfire nozzles. The result obtained on the 420-t/h boiler are illustrated in Figure 15: $\mathrm{NO}_{\mathrm{x}}$ concentration was reduced by $35-45$ percent $[25,29]$.

Reburning will be more extensively tested in the near future in a 500-t/h boiler.

To decrease $\mathrm{NO}_{\mathbf{x}}$ formation, a scheme with.brown coal dust preheating in a direct fired system has been designed. When firing the coal dust preheated to $600-950^{\circ} \mathrm{C}$ at the pilot facility, $\mathrm{NO}_{\mathrm{x}}$ formation was reduced 2.5 times, and in the case of reburning, more than 3 times. At the pilot $35-\mathrm{t} / \mathrm{h}$ boiler, $\mathrm{NO}_{\mathrm{x}}$ concentration was reduced from $400-500 \mathrm{mg} / \mathrm{m}^{3}$ to $220-300 \mathrm{mg} / \mathrm{m}^{3}$. Further $\mathrm{NO}_{\mathrm{x}}$ reduction could be predicted to $200-250 \mathrm{mg} / \mathrm{m}^{3}$ [28]. Technical 
solutions for coal dust preheating and staged combustion have been designed for a P-67 .. 800-MW unit and 500-t/h boilers:

As mentioned above, there are possibilities of long-distance transport of K-A coals. As briquettes, for example. In this case, the firing conditions will be different but not new to the Russian industry. For example, there are many years of experience with the combustion of dry, centrally-treated Nazarovo field $\mathrm{K}-\mathrm{A}$ coal dust in wet-bottom boilers. $\mathrm{NO}_{\mathrm{x}}$ emissions were reduced under such conditions by using a highly concentrated coal-air mixture: $50 \mathrm{~kg}$ of coal dust per $1 \mathrm{~kg}$ of air. The typical dependence of the furnace outlet $\mathrm{NO}_{\mathrm{x}}$ concentration . upon excess air is shown in Figure 16 with reference to a $680-700-t / h$ boiler $[31,7]$.

All of the low-NO $\mathrm{NO}_{\mathrm{x}}$ burners and reburning technologies (7-40, 7-42, 7-44, 7-52) demonstrated under the DOE Clean Coal Technology Program (CCTP) for bituminous coal-fired boilers can be implemented when firing the Russian coals discussed above. The U.S. technical solutions will compete with those available in Russia. Joint development using, for example, U.S.A. burners, mills for superfine grinding of coal for coal reburning, measurement and control devices, etc., could be attractive.

Where primary technological measures fail to attain the required $\mathrm{NO}_{x}$ emissions, noncatalytic and catalytic de-NO $\mathrm{N}_{\mathbf{x}}$ systems will be used.

Russia has experience with the noncatalytic system of $\mathrm{NO}_{\mathrm{x}}$ reduction by injection of ammonia water into the high-temperature (about $1000^{\circ} \mathrm{C}$ ) boiler path. Test were conducted at two 420-t/h natural gas and Kuzn coal-fired boilers. When firing coal, $\mathrm{NO}_{\mathrm{x}}$ concentrations with ammonia water injection were decreased by almost 2 times [28]. Now the system is automated, based on U.S. measurement devices.

Projects have been designed for catalytic de-NO $\mathrm{N}_{\mathrm{x}}$ systems for 500-MW Ekib coal unit (see below) where the catalytic reactor is located before and after the particulate matter and the $\mathrm{SO}_{\mathbf{x}}$ gas cleaning devices in the dust-laden flue gas boiler duct. Pilot and industrial test are being carried out on Russian- and foreign-developed catalyst for de-NO $\mathrm{N}_{\mathrm{x}}$ systems using real dust-laden flue gases.

The flue gas $\mathrm{SO}_{2}$ concentrations when Kuzn coals are fired are generally within $300-350 \mathrm{mg} / \mathrm{MJ}\left(800-1,100 \mathrm{mg} / \mathrm{m}^{3}\right)$. For the Neryungri coals the figures are half as high. As specified in the prepared National Standard, such emissions allow for boiler operation with no special flue gas $\mathrm{SO}_{2}$ cleaning measures. 
Wherever required in firing Kuzn, Neryungri and Ekib coals, use may be made of simple de$\mathrm{SO}_{\mathrm{x}}$ technologies employing wet ash collectors (see above) and wet/dry devices, in particular, those that are integrated into the gas duct. Their efficiency will be at 50-70 percent. Among the CCTP DOE technologies that can be used are those demonstrated in project 7-54, 7-56, $7-58,7-60$, and 7-62.

In ecologically dangerous locations when Ekib, and to a lesser extent Kuzn and Neryungri coals, and as a rule Pech and Donetk coals are fired, the use of wet/dry technologies in special apparatus for about 90 percent sulfur capture can be required. Such technologies are being developed, in particular, under CCTP DOE project.

As mentioned previously, low-sulfur, low-ash K-A coals feature high-calcium-content ash $(\mathrm{CaO}=26-42$ percent for different coal fields, including 17-32 percent of free $\mathrm{CaO}$; $\mathrm{CaO} / \mathrm{SO}_{2}=2.5-5.3$; free $\mathrm{CaO} / \mathrm{SO}_{2}=1.1-3.5$ ). With low-temperature, dry-bottom furnace combustion of such coals, up to $40-60$ percent of the sulfur (Figure 17) is captured in the furnace volume [33]. Injection of activated ash containing much unused active $\mathrm{CaO}$ into the gas duct adds to the degree of sulfur capture by about 20 percent. The jet-mill, crushed ash is better if injected into the furnace top; and that which is processed in the digester is better if injected into the convective section where gas temperature is $500-600{ }^{\circ} \mathrm{C}$.

If a baghouse is used to clean the gases of particulate matter, additional sulfur is captured in the ash layer that forms on the filter material. Ultimately, with additional injection of activated ash, the overall sulfur capture in the dry system without external sorbent may reach $80-90$ percent [37].

To clean combustion product resulting from the combustion of near-Moscow field 3 percent $S$ brown coal, a demo plant of $400,000 \mathrm{~m}^{3} / \mathrm{h}$ capacity, based on the ammonia-cyclic-technology has been constructed at one of the utility boilers of the Dorogobuzh TPS. This method is based on the $\mathrm{SO}_{2}$ absorption by ammonia sulphite and the formation of hydrosulfite and sulphate. The final product are 10 percent liquid $\mathrm{SO}_{2}$, crystalline ammonia sulphate and colloidal sulfur. Basic characteristics of the plant are given below. 


\begin{tabular}{|c|c|}
\hline Flow of flue gases to be cleaned, $\mathrm{m}^{3} / \mathrm{h}$ & 400,000 \\
\hline \multicolumn{2}{|l|}{ Flue gas temperature, ${ }^{\circ} \mathrm{C}$ : } \\
\hline Before de-SO ${ }_{x}$ system & 150 \\
\hline Past de-SO ${ }_{x}$ system & $45-55$ \\
\hline \multicolumn{2}{|l|}{ Flue gas $\mathrm{SO}_{2}$ concentration, $\mathrm{mg} / \mathrm{m}^{3}$ : } \\
\hline Before de-SO ${ }_{x}$ system & 5500 \\
\hline Past de-SO ${ }_{x}$ system & $300-350$ \\
\hline \multicolumn{2}{|l|}{ Flue gas $\mathrm{NO}_{\mathrm{x}}$ concentration, $\mathrm{mg} / \mathrm{m}^{3}$ : } \\
\hline before de-SO ${ }_{x}$ system & $350-400$ \\
\hline past de-SO $\mathrm{S}_{\mathrm{x}}$ system & $200-250$ \\
\hline \multicolumn{2}{|c|}{ Yield of de-SO ${ }_{x}$ system by-product with 7,000 -hour operation, $t / y:$} \\
\hline Liquid $\mathrm{SO}_{2}$ & 18,000 \\
\hline Ammonia Sulphate & 14,200 \\
\hline Colloidal Sulfur & 214,500 \\
\hline Annual ammonia consumption, $t / y$ & 1,830 \\
\hline
\end{tabular}

The plant efficiency and the consumption of the reagent required for operation are being refined.

The lowest emissions, sometimes below those specified in the Standards, and the highest flue gas cleaning efficiency will be required for cogeneration plant located in towns, sometimes in residential areas, and also for industrial cogeneration plant in highly contaminated areas.

In all cases of conventional bituminous coal combustion, the washing of raw coals would be reasonable to decrease the ash content. This would facilitate the ash collection and removal and also facilitate the use of the various technologies for emission reduction and flue gas cleaning. 



\section{BASE OPTIONS OF ADVANCED COAL THERMAL POWER PLANT}

The following base-option project were deemed to be winners of the competition by their inclusion in the "Clean Coal Technology" section of the State Program "Ecologically Clean Power Generation." [35, 36]

Basic parameters of the TPS employing various technologies are shown in Table 23.

It is difficult to compare the technologies on the basis of economic parameters for the following reasons: They have been designed around coals of differing properties and cost. The TPS have been sited in differing geographic locations. Different operating modes have been employed. Finally, equipment and construction cost have been unstable and not always fully justifiable.

The lowest specific cost relate to TPS with low-cost 500-MW unit firing Ekib bituminous coal. TPS with brown K-A coal fired 800-MW unit are higher in cost because the lower combustion temperatures necessary to prevent ash slagging dictate larger physical dimensions for the furnace (see Section 2). The lack of Russian experience with direct flue-gas removal of $\mathrm{SO}_{x}$ and $\mathrm{NO}_{x}$ has led to conservative cost estimates for such equipment and TPS utilizing it. By contrast, the specific cost for CFB boilers seems optimistic for the very same reason.

\subsection{4-GW TPS Project with 800-MW, Brown K-A Coal-Fired Unit}

The 6.4-GW TPS featuring 8 800-MW supercritical boilers firing brown coal from the Berezovz field is a base option.

Principal features of the P-67 boiler (Figure 5) at the Berezovo TPS-1 are: Dry-bottom, tangential-fired furnace. Low active combustion zone heat-release rate. Low flame temperatures, i.e., $1,300-1,400{ }^{\circ} \mathrm{C}$ maximum. Early ignition and intensively pulverized coal (PC) burnup at the initial point.

Specific coal composition as regards mineral and organics content allowed $\mathrm{SO}_{\mathrm{x}}$ and $\mathrm{NO}_{\mathrm{x}}$ reduction and attainment of ecologically-required levels of $\mathrm{SO}_{x}$ and $\mathrm{NO}_{\mathrm{x}}$ of $200-300 \mathrm{mg} / \mathrm{m}^{3}$ without special de-SO $\mathrm{SO}_{\mathrm{x}}$ and de-NO $\mathrm{NO}_{\mathrm{x}}$ systems $[7,28,37]$.

The following methods will be employed for $\mathrm{NO}_{\mathrm{x}}$ reduction: fuel preheated to $650-850^{\circ} \mathrm{C}$, staged low excess air combustion and combustion gases used for fuel drying in the 
pulverizing mill fans system. A schematic drawing of the coal preparation and firing systems for the P-67 boiler is illustrated in Figure 18. The raw coal from the hopper enters the drying section at 33 percent moisture. This is reduced to 13 percent by the $590-650^{\circ} \mathrm{C}$ combustion gases. Also, the fuel is classified by the mill fan into high and low solids concentration . streams. A portion of the coal-air mixture is fed to the muffle burner where it is used for heating the main stream in the PC preheater. To ensure complete.combustion and minimize slagging of the boiler's heat-exchange surfaces, simultaneous coal particle size reduction from $R_{90}=40-60$ percent to $R_{90}=20-30$ percent and $R_{1000}<1.5$ percent is required.

Low-temperature combustion allows for sulfur capture within the furnace of up to 50 percent by the calcium in the ash. Fabric filters are used to clean the flue gases and additional sulfur is captured in the fly-ash layer on the filter bags. Also, feed of activated ash into the furnace and the convective path is provided.

Firing Berezovo coal with 0.4-0.5 percent sulfur in pilot test showed that the $200 \mathrm{mg} / \mathrm{m}^{3}$ maximum requirement can be assured by the above methods of sulfur capture in the furnace and on the flue gas filter bags. The cleaning efficiency of the fly-ash layer on the filter bags is sufficient to meet the specified ecological maximum of $50 \mathrm{mg} / \mathrm{m}^{3}$.

Technical data for the FRO-12000 baghouse module is shown in Table 24. Figure 19 illustrates the two-storey layout of the baghouse bay adopted for the TPS.

Operation on coal with 7 percent average ash content will yield $1.5 \times 10^{6} \mathrm{t} / \mathrm{y}^{-}$of ash and slag wastes.

Because the $\mathrm{K}-\mathrm{A}$ coal ash contains $\mathrm{CaO}$, provision is made for its granulation (as $\mathrm{CaSO}_{4}$ ) by treating with acid waste water from the make up treatment system to improve salability properties and prevent environmental impact when land filling.

The 6.4-GW TPS is constructed within two main buildings. Each contains 4 of the 800-MW unit. Each unit has it own $84 \mathrm{~m}$ wide bay. Overall, each main building is $434 \mathrm{~ms}$ wide and $177 \mathrm{~ms}$ deep. The baghouses and the induced-draft fans are located in separate buildings. Two $250 \mathrm{~m}$-high stacks are provided, each serving four unit (Figure 20).

The proposed new technologies for the project are being perfected in the $35 \mathrm{t} / \mathrm{h}$ pilot boiler: The influence upon $\mathrm{NO}_{\mathrm{x}}$ of the high temperature preheating of the $\mathrm{PC}$ and staged combustion, $\mathrm{SO}_{\mathrm{x}}$ capture in the boiler gas path and in the baghouse, and injection of ash activated in the 
jet mill or digester at various point in the gas path are being quantified.

These techniques will be further tested in a 500 th boiler presently under construction and due to be started up in 1996.

The result of experiment aimed at validating this project were considered briefly in Section 5.2.

Basic parameters of the TPS employing $800 \mathrm{MW}$ unit designed under this project are shown in Table 23. It is compared with alternative TPS based on the same coal technology below:

\begin{tabular}{|c|c|c|c|}
\hline & $\begin{array}{l}\text { Existing unit w/o } \\
\text { de-SO } \text { de-NO }_{x} \\
\text { systems }\end{array}$ & $\begin{array}{l}\text { Existing unit } \\
\text { with de-SO }{ }_{x} / \\
\text { de- } \mathrm{NO}_{x} \text { systems }\end{array}$ & Base option \\
\hline Efficiency at nominal output, $\%$ & 38.50 & 37.50 & 39.20 \\
\hline Mean annual efficiency, \% & 38.07 & 37.28 & 38.85 \\
\hline $\begin{array}{l}\text { Mean annual specific standard } \\
\text { fuel consumption, } \mathrm{g} / \mathrm{kWh}\end{array}$ & 323.10 & 329.90 & 316.60 \\
\hline Relative specific investment & 0.978 & 1.24 & 1.00 \\
\hline $\begin{array}{l}\text { Relative averaged electricity } \\
\text { cost }\end{array}$ & 0.996 & 1.23 & 1.00 \\
\hline \multicolumn{4}{|c|}{ Specific emissions, $\mathrm{mg} / \mathrm{m}_{3}$} \\
\hline $\mathrm{NO}_{\mathrm{x}}$ & 600 & 200 & 200 \\
\hline $\mathrm{SO}_{\mathrm{x}}$ & 600 & 300 & 300 \\
\hline Particulate matter & 150 & 50 & 50 \\
\hline
\end{tabular}

\subsection{Yuzhno-Ural Ekib Bituminous Coal-fired 4-GW TPS with 500-MW Unit Project}

The base option is a 500-MW supercritical unit with conventional PC firing [38]. Some parameters of the unit and TPS are shown in Table 23.

The P-57, 1,650 t/h, $24 \mathrm{MPa}, 545 / 545^{\circ} \mathrm{C}$ boiler manufactured by the Podol'sk Machine 
Building works in 1986 was adopted as the prototype.

Conventional firing of Ekib coal in the P-57 boiler generates rather high $\mathrm{NO}_{\mathrm{x}}-$ in the order of $800-1,300 \mathrm{mg} / \mathrm{m}^{3}$. Two versions of the furnace have been specifically designed with technologies intended to reduce $\mathrm{NO}_{\mathbf{x}}$ emissions.

The furnace is equipped with two tiers of wall swirl burners (Figure 21), and has additional straight-flow burners arranged 3-4 $\mathrm{m}$ above the second tier. These burners, operating with SR $=0.7$, handle 20 percent of the fuel. Above them, at $26-30 \mathrm{~m}$ elevation, nozzles are arranged to feed 10-24 percent of the total air.

The tangentially-fired furnace (Figure 22) has 24 straight-flow burners arranged in three tiers of eight burners (two set of four) each on the side walls with the coal/air channels of each set aimed at the perim of a 1,200 millim diameter circle situated in the space between them so as to generate a counter-clockwise "swirl." Burners of the first and second tiers operate at excess air of $S R=1.1$ and those of the third tier with $S R=0.7$. About 15 percent of the secondary air is fed through the tertiary air nozzles located about $8 \mathrm{~ms}$ above the third tier of burners.

The result of pilot and industrial-scale tests at the Ekib TPS-2 indicate that this technique can reduce the $\mathrm{NO}_{x}$ emissions in the $\mathrm{P}-57 \mathrm{R}$ boilers to $500-550 \mathrm{mg} / \mathrm{m}^{3}$.

Further reduction of $\mathrm{NO}_{x}$ will be effected by application of selective catalytic reduction (SCR) using ammonia. The specific location for the SCR catalyst has been analyzed in view of the high dust content and dust abrasivity of the Ekib coal. A line drawing showing the de- $\mathrm{NO}_{\mathbf{x}}$ system after the hot electrostatic precipitator and before the air heater, and another showing it after both the de-SO $\mathrm{S}_{\mathrm{x}}$ unit and the air heater appear as Figures 23 and 24, respectively.

Operating conditions and some characteristics of the catalyst for these schemes are illustrated in Table 25. The de-NO ${ }_{x}$ system located in the flue ahead of the air heater is more efficient.

Reduction of $\mathrm{SO}_{\mathbf{x}}$ will be accomplished in a wet lime scrubber with gypsum produced as a by-product. A schematic of the process appears as Figure 25 with basic process parameters presented in Table 26.

Fly ash production is one of the most serious problems with Ekib coal combustion. Ash removal efficiency of 99.9 percent is required to reduce the dust content from the reference value of $90 \mathrm{~g} / \mathrm{m}^{3}$ to $100 \mathrm{mg} / \mathrm{m}^{3}$. This is difficult with Ekib coal because of increased 
electrical resistivity of the fly ash. Within the temperature range of $140-180^{\circ} \mathrm{C}$, this causes back corona in the electrostatic precipitator which impairs ash separation.

The required efficiency can be reached by maintaining the stack gas at $95-100^{\circ} \mathrm{C}$ along with adequate gas velocity and residence time within the ESP active zone. Utilizing four 8-pole ESPs, each with $12 \mathrm{~m}$ high electrodes and an active cross-section of $197.5 \mathrm{~m}^{2}$, the cleaned gas velocity will be about $\mathbb{1} \mathrm{m} / \mathrm{s}$ and the residence time within the ESP more than $30 \mathrm{~s}$. These conditions ensure a $100 \mathrm{mg} / \mathrm{m}^{3}$ maximum fly ash content in the cleaned gas stream. The elecrostatic precipitators are equipped with variable voltage supply sources which prevent back corona and increase operational reliability.

Reduced power output and efficiency caused by the use of the gas cleaning systems is to some extent compensated by extra syngas production as a result of steam condensed instead of being extracted. This is because some condensate and, in some cases, feedwater, are heated by boiler flue gases as a result of less steam flow to preheating. The temperature of the flue gas is reduced from $160^{\circ} \mathrm{C}$ to $90-100^{\circ} \mathrm{C}$ to meet ESP operating conditions. For this temperature reduction, low-temperature economizers or heating of excess air have been designed. In the latter case, a larger amount of air than required for combustion is passed via the air heater, while part of the air preheated to $300-330^{\circ} \mathrm{C}$ recirculates, heating feedwater and condensate (Figure 26, and mean SR). The requirement of low gas velocities for the ESP greatly influences the system layout.

The plant configuration with included de- $\mathrm{NO}_{\mathrm{x}}$ system and an $84 \mathrm{~m}$ wide bay housing the electrostatic precipitators is shown in Figures 27 and 28.

Table 27 compares the performance of the existing Ekib TPS-2 power plant without gas cleaning equipment, a $500 \mathrm{MW}$ unit with the de- $\mathrm{NO}_{x}$ system located in the furnace flue-gas stream, and a $500 \mathrm{MW}$ unit with the de- $\mathrm{NO}_{\mathrm{x}}$ system located after the ESP and the de-SO system.

Different combustion systems have been tested to validate this project. A tangential-fired furnace has been implemented at the Ekib TPS-2 $500 \mathrm{MW}$ plant. This has resulted in a reduction in $\mathrm{NO}_{\mathrm{x}}$ emissions to $500-650 \mathrm{mg} / \mathrm{m}^{3}$, i.e., almost 50 percent, compared with emission of $1,100-1,200 \mathrm{mg} / \mathrm{m}^{3}$ from other boilers.

The swirl burner with simplified reburning has been tested on a 210 th Ekib coal fired boiler. In this case, $\mathrm{NO}_{\mathrm{x}}$ emissions were reduced 47 percent, from $1,100 \mathrm{mg} / \mathrm{m}^{3}$ to $520-570 \mathrm{mg} / \mathrm{m}^{3}$. 
Long-term test of the de-NO ${ }_{x}$ system catalyst have begun on heavily dust-laden Ekib coal fired combustion product. The catalyst are installed in a bypass duct of the existing $500 \mathrm{MW}$ boiler flue, and see about $5,000 \mathrm{~m}^{3} /$ hour of gas flow.

A low temperature economizer reducing flue gas temperature to $90-100^{\circ} \mathrm{C}$, is installed on a $420 \mathrm{t} / \mathrm{h}$ boiler. The resulting change in the electrophysical properties of the fly ash improved ESP efficiency and reduced fly ash emissions by factors of 3.

Pilot tests were conducted of the simplified de- $\mathrm{SO}_{\mathrm{x}}$ system which is close in concept to the LIFAC system. Sulfur capture and the effect upon the system of lime injection into the high temperature $\left(800-1,000^{\circ} \mathrm{C}\right)$ flue gas stream were tested, as well as sulfur capture with this system using various methods of humidification of the $\mathrm{CaO}$-laden flue gas stream.

Effort are under way to develop heat exchangers for de-SO $\mathrm{S}_{\mathrm{x}}$ and de- $\mathrm{NO}_{\mathrm{x}}$ systems.

\subsection{2,400MW TPS with CFB Boilers Firing Poor-Quality Anthracite Culm (AC)}

Circulating Fluidized Bed (CFB) combustion is a promising approach to firing poor fuels [8, $11,39]$. A project utilizing this technology has been developed featuring a 2,400 MW TPS with $300 \mathrm{MW}$ unit located in the Eastern Donbass.

The TPS employs once-through, two-furnace, $2,500 \mathrm{t} / \mathrm{h}, 24.5 \mathrm{MPa}, 545 / 545^{\circ} \mathrm{C} \mathrm{CFB}$ boiler and K-300-240 steam turbine. The fuel is poor quality anthracite culm with 36 percent ash, 1.4 percent sulfur, 10 percent moisture and 4-6 percent volatiles. The boiler features a high recirculation ratio, external "hot" (900-940 ${ }^{\circ} \mathrm{C}$ ) cyclones and special external heat exchangers for cooling a portion of the cyclone ash before it is returned to the furnace. For boiler startup and for operation at loads less than 30 percent of nominal design, each combustion chamber has 6 gas/oil burners arranged on the front and rear walls and is equipped with primary air preheating up to $650-700^{\circ} \mathrm{C}$.

The coal and limestone preparation system uses common hoppers and cyclones and the crushed coal and limestone are combined as feed to the boiler. The coal and limestone mean particle size are $0-4 \mathrm{~mm}$ and $0.55 \mathrm{~mm}$, respectively.

Reduction of the stack gas temperature to $100{ }^{\circ} \mathrm{C}$ while heating ambient air (see Figures 26 and 29) for use as combustion air serves to increase ESP efficiency and result in particulates emissions below $50 \mathrm{mg} / \mathrm{m}^{3}$. 
Figure 29 is a schematic drawing of the unit. Layout and operation are simplified, and capital investment reduced, by elimination of the deaerator in favor of two, direct-contact, lowpressure heaters. Air preheating is used to prevent boiler cooling during hot startup of the unit operating in a shifting mode. The boiler is provided with a full-flow separator, and the waterwall hydraulics are designed to start the unit at sliding pressure across the entire boiler system. The two-bypass starting scheme is provided to improve temperatures when the turbine is placed in operation.

The once-through CFB boiler design is illustrated in Figures 30 and 31 . The firing system consist of 2 modules. Each module has it own furnace, two cyclones and two external heat exchangers located under the cyclones. The combustion product from both modules are directed through a common convective section.

The primary air fed through the fluidizing screen is about 50 percent of the total required for complete combustion. The velocity of the combustion gases at the outlet of the dense bed is $6.4 \mathrm{~m} / \mathrm{s}$. Fuel is fired in the combustor freeboard (the upper part) using secondary air supplied by special nozzles.

The combination of two-stage air feed, high fly ash recirculation ratio, $900{ }^{\circ} \mathrm{C}$ furnace temperature and limestone injection insures low concentrations of $\mathrm{SO}_{\mathrm{x}}$ and $\mathrm{NO}_{\mathrm{x}}$ in the flue gas. Complete combustion, i.e., 94-97 percent, of the anthracite culm fuel and possible reduction of boiler loads to 30-50 percent of nominal design rates are attained without firing fuel oil or gas. The external heat exchangers, along with the last stages of the primary superheater and reheater, are designed for 60 percent heat recovery from the CFB firing circuit.

The design and thermo-hydraulic boiler parameters can be seen in Tables 28 and 29.

The ash will be landfilled on site and/or, depending upon it properties, used for water treatment, to reduce effluent volumes and the requirement for treatment chemicals.

The layout of the CFB boiler in the main building and of the TPS as a whole are shown in Figures 32 and 33.

The performance of the TPS with CFB boilers is illustrated in Table 23, which also compares the TPS with pc-fired boilers both with and without de-SO and de-NO $\mathrm{N}_{\mathrm{x}}$ systems. Given identical environmental impact, construction of a 300-MW TPS with CFB boilers under this 
project will be 20-25 percent cheaper than a pc-fired unit with de-SO $\mathrm{S}_{x}$ and de-NO $\mathrm{N}_{x}$ systems.

Comprehensive testing was done in order to validate the engineering assumptions used in designing the above boilers. Conditions tested were: Kuzn coal and anthracite culm firing, $\mathrm{NO}_{\mathrm{x}}$ and $\mathrm{SO}_{\mathrm{x}}$ suppression, hydrodynamics of dust-laden flows under typical CFB duct conditions, and boiler startups and shutdowns. The result obtained made possible the determination of the main characteristics of the processes; kinetic constant necessary for calculations; measures necessary to ensure complete combustion of the anthracite culm; sulfur capture and suppression of $\mathrm{NO}_{x}$ formation in the furnace, e.g., temperature conditions, air feed staging, sorbent dosing; and also pointed to the improvement of CFB boiler critical component, e.g., cyclones, fly ash reintrainment path lockhoppers and others.

The highest anthracite culm firing efficiency - 96 percent - was obtained by supplying 60 percent of the total air to the primary zone. At conditions of equal flow between primary and secondary air, i.e., 50-50 percent, and overall furnace excess air of $\mathrm{SR}=1.15-1.25$ the flue gas $\mathrm{NO}_{\mathrm{x}}$ concentration was $200 \mathrm{mg} / \mathrm{m}^{3}$ maximum. Also, $\mathrm{NO}_{\mathrm{x}}$ formation is perceptably influenced by both sorbent feed rate to the boiler and $\mathrm{Ca} / \mathrm{S}$ ratio. At furnace temperatures of $740-940^{\circ} \mathrm{C}, 90-95$ percent of the sulfur is captured at $\mathrm{Ca} / \mathrm{S}=1.7-2.0$. With further increase of the $\mathrm{Ca} / \mathrm{S}$ ratio, sulfur capture remains essentially constant at about 95 percent (see Figure 34).

Investigations were done on the quality of the ash from CFB coal combustion with limestone addition. As a result, technical solutions were found that ensure ESP performance with increased electrical resistivity of the fly ash

Fuel and limestone preparation equipment for CFB boilers has been tested and coal and limestone crushers have been designed which provide for the proper size composition.

CFB combustion technology also holds promise for brown coals. Some result of work in this area were illustrated in Section 2. The largest and most interesting systems for firing brown coals are the $420 \mathrm{t} / \mathrm{h}$ bubbling-bed and the $500 \mathrm{t} / \mathrm{h}$ CFB boilers.

In the $420 \mathrm{t} / \mathrm{h}$ boiler fuel preparation system, $\mathrm{K}-\mathrm{A}$ coal is separated into fractions. The 1$25 \mathrm{~mm}$ sized coal is fed beyond the bed, while the $0-1 \mathrm{~mm}$ sized material is injected directly into the bed by pneumatic-screw type pumps. The fly ash reentrainment system includes the louvre-type ash collector, 8 cyclones and ejectors to feed the collected fly ash to the lower section of the bed. 
K-A coal properties are rather attractive for CFB combustion technology: up to 95 percent sulfur capture by the $\mathrm{CaO}$ in the ash can be expected at $850-900^{\circ} \mathrm{C}$, no slagging of heating surfaces, $\mathrm{NO}_{\mathrm{x}}$ reduction, lower sensitivity of the system to the quality of fuel fired, and better ash properties for further utilization.

Investigation of Irsha-Borodino brown coal combustion in the pilot plant and foreign operating experience with CFB boilers indicate that with K-A coals, emissions of $\mathrm{NO}_{\mathrm{x}}$ and $\mathrm{SO}_{x}$ will be $200 \mathrm{mg} / \mathrm{m}^{3}$ maximum.

The good ecological characteristics of the CFB boilers give them an initial advantage for both new and reconstructed city cogeneration plant.

The Barnaul Boiler Manufacturing Works designed 500 th boilers based on "cold" cyclones [40] for combustion of high-sulfur brown coal from the Moscow area (Novomoscovskaya TPS) and K-A coal (Omsk cogeneration plant No. 6). The drum boiler with heating surfaces in a tower arrangement has a furnace plan section with dimensions of $19.3 \times 8.0 \mathrm{~m}$ (Figure 35). The furnace is the key element in solids circulation. It has an all-welded, gas-tight waterwall design. At the bottom of the furnace is a cap-type, perforated-screen air distributor with directed blasting, through which about 50 percent of the total air passes as primary air. The remaining air is fed through secondary air nozzles arranged in three tiers on the side walls. Provision is also made to feed recirculation gases into the primary air stream. The construction of such boilers is presently delayed by economic problems within the country.

\subsection{IGCC TPS Project with Entrained-Flow and Moving-Bed Coal Gasification}

A large-capacity (4.0-6.5-GW) Integrated Gasification Combined-Cycle (IGCC) TPS has been designed to use Kuzn and K-A (Berezovo) coals.

The 600-700-MW Combined-Cycle (CC) plant includes two gas turbine/generators (GT) of 200-MW each, two heat recovery boilers and a single 240MW steam turbine/generator (ST). Some of the characteristics of this equipment can be seen in the Appendix (pages 67-71).

The CCP designs are based on two different gasification technologies: moving bed and entrained flow. Each system was designed with both air blown and (95 percent pure) oxygenblown options. The technical considerations and the equipment are to a great extent universal and, therefore, various grades of coal can be used including those with high sulfur content. 
Gasification proceeds at about $3 \mathrm{MPa}$ pressure. In both systems, slagging gasifiers are fed dry coal through lockhoppers.

As feed for the moving-bed gasifier, coal is first dried and crushed to $<50 \mathrm{~mm}$ size. This coal is screened. Material $<50 \mathrm{~mm}$ and $>5 \mathrm{~mm}$ is stored in a hopper and fed into the top of the gasifier vessel via a lockhopper system. The coal fines $(<5 \mathrm{~mm}$ ) are milled and fed via a second lockhopper system to the tuyeres through which they are blown into the gasifier. Technology also was tested whereby excess fines are pressed into pellet of $6-10 \mathrm{~mm}$ size. These are fed into the gasifier with the screened coal.

As feed for the entrained-flow gasifiers, the coal is milled, passed through lockhoppers and conveyed into the gasifier as highly concentrated dust $(0.015 \mathrm{~kg}$ of nitrogen per $1 \mathrm{~kg}$ of coal).

Coal-derived gas (syngas) is used for sealing purposes and as a transport agent in the airblown systems. In oxygen-blown systems, nitrogen, coproduced with the oxygen, is used for these purposes.

The composition of the syngas produced by gasification of dried coal depends largely upon the process conditions, e.g., kind and temperature of the blast, steam consumption, temperature, pressure, etc. Syngas composition is only very sleghtly influenced by the elementary composition of the coal.

The temperature of the syngas at the reactor outlet is dependent upon the process: moving bed, oxygen-blown $=500-559^{\circ} \mathrm{C}$; moving bed, air-blown $=900-960^{\circ} \mathrm{C}$ and entrained-flow $=$ $1,300-1,600^{\circ} \mathrm{C}$.

Preliminary cooling of the entrained-flow gasifier syngas to $900-950^{\circ} \mathrm{C}$ is done either in a radiant gas cooler featuring platen-type heat exchange surfaces, or by quenching with recirculated, cooled gas to the reactor outlet. Further cooling of the gas stream to 500 $550^{\circ} \mathrm{C}$, at which temperature it can be cleaned, is done in convective coolers.

As much as 30 percent of the steam consumed in the steam turbine/generator is produced in the gasifier waterwall and the radiant and convective syngas coolers.

The raw syngas is cleaned of sulfur at $500^{\circ} \mathrm{C}$ by passing the gas stream through a fluidized bed of oxidized metal, e.g., iron. The sorbent is regenerated and the regeneration gases used to produce sulfuric acid (see Appendix). 
For the oxygen-blown cases, standalone air separation facilities are required (see Appendix).

Air-blown gasification systems feature two trains of gasification for each gas turbine/generator. In oxygen-blown cases this is one-to-one.

Figure 36 is a flow sheet of an IGCC with moving-bed, air-blown gasification. An IGCC featuring entrained-flow, oxygen-blown gasification is shown in Figure 37. Both of these are considered principal technologies and have received detailed study.

The layout for a moving-bed, slagging gasifier is illustrated in Figure 38, and it associated convective gas cooler shown in Figure 39.

The design of one version of an entrained-flow gasifier is shown in Figure 40.

Figure 41 is a schematic drawing of a syngas cleaning system. Figure 42 is a flow sheet for the generation part. Parameters and descriptions for the gas turbine, the heat-recovery boilers and the steam turbine are in the associated appendix. Figure 43 is a sectional view of the heat-recovery boiler.

The exhaust gas flow from the gas turbine is greatly dependent upon ambient air temperature, and ranges from $560-580 \mathrm{~kg} / \mathrm{s}$ at $+30^{\circ} \mathrm{C}$ to $830-850 \mathrm{~kg} / \mathrm{s}$ at $-30^{\circ} \mathrm{C}$. At the average ambient air temperature of $-5^{\circ} \mathrm{C}$, the gas flow is $700-730 \mathrm{~kg} / \mathrm{s}$.

For the air-blown gasification case, approximately $100 \mathrm{~kg} / \mathrm{s}$ of air is extracted from the gas turbine compressor for gasification air. After extraction, this air stream is cooled and fed to a 15-MW booster compressor whose outlet temperature is held at $500-540{ }^{\circ} \mathrm{C}$ maximum. The booster compressor is driven by a condensing steam turbine consuming about $50 \mathrm{t} / \mathrm{h}$ of steam. The resulting air pressure is $3.2 \mathrm{MPa}$. The gasifier also is fed superheated steam.

The heat recovery boilers are dual-pressure, wherein $13.8 \mathrm{MPa} / 520^{\circ} \mathrm{C}$ and $0.4 \mathrm{MPa} / 240$ $250^{\circ} \mathrm{C}$ steam is generated by the heat from the turbine exhaust. Given 2 turbines and 2 heat recovery boilers, $2 \times 205=410 \mathrm{th}$ of high pressure steam is generated. Additionally, about $170 \mathrm{t} / \mathrm{h}$ of high pressure steam is supplied to the steam turbine by the gasification plant. This steam is expanded in the high pressure cylinder of the steam turbine and then reheated in heat-recovery boilers. The steam flowing to the steam turbine's intermediate-pressure cylinder is at $2.2 \mathrm{MPa} / 460^{\circ} \mathrm{C}$. 
A portion of the low-pressure steam produced in the heat-recovery boilers is used for coal drying. This amount to $85-130 \mathrm{t} / \mathrm{h}$ out of the total make of $185-210 \mathrm{t} / \mathrm{h}$. The remaining lowpressure steam is fed to the low pressure cylinder of the steam turbine.

For the oxygen-blown gasification, a KT-70, $66,000 \mathrm{~m}^{3} / \mathrm{hr}$ air separation plant is used to produce the required oxygen. Specifications for this plant can be found in the Appendix.

More steam is produced in the entrained-flow, oxygen-blown integrated gasification combined-cycle than in the air-blown plant. This amount to $607 \mathrm{t} / \mathrm{h}$, as compared with $580 \mathrm{t} / \mathrm{h}$ in the air-blown case.

The layout of the main building for the commercial TPS with 10 IGCC unit is shown in Figure 44. A cross-section of the building along the gas turbines and heat recovery boilers and a cross-section of the ST building is shown in Figure 45. The section of the gasifier plant with a moving-bed and air-blown design is shown in Figure 46. Figure 47 illustrates the general layout of a TPS with 10 gasification combined cycle units using K-A coals.

Basic parameters of the IGCC plant at standard ISO conditions are given below:

\begin{tabular}{|l|c|c|c|c|}
\hline \multirow{2}{*}{ Param } & \multicolumn{4}{|c|}{ Type of Gasifier and Oxidizer } \\
\cline { 2 - 5 } & \multicolumn{2}{|c|}{ Moving bed } & \multicolumn{2}{c|}{ Entrained Flow } \\
\cline { 2 - 5 } & Oxygen & Air & Oxygen & Air \\
\hline Two GT Output, MW & 418 & 413 & 414 & 372 \\
\hline ST Output, MW & 188 & 220 & 233 & 227 \\
\hline CCP Output (gross), MW & 606 & 633 & 647 & 600 \\
\hline Auxiliary Power, MW & 68 & 32 & 94 & 31 \\
\hline CCP Output (net), MW & 538 & 601 & 553 & 569 \\
\hline CCP Efficiency (net), Percent & 43.4 & 44.2 & 43.8 & 44.1 \\
\hline Live Steam HP Flow, t/h & 454 & 532 & 574 & 551 \\
\hline Live Steam HP Temperature, ${ }^{\circ} \mathrm{C}$ & 535 & 540 & 540 & 540 \\
\hline Fuel Saving, Percent & 10.1 & 11.8 & 11.0 & 11.6 \\
\hline
\end{tabular}


The fuel saving compares IGCC with that of a conventional steam supercritical unit operating at 39 percent efficiency. The data are shown in more detail in Table 30.

During commercial operation the average IGCC output and efficiency will be lower by $30-$ $35 \mathrm{MW}$ and by $1.0-1.5$ percent respectively.

The efficiency of CCP utilizing various gasification technologies is almost the same. With the oxygen-blown option, efficiency is $1.7-2.5$ percent lower than with the air-blown configuration.

Combined-cycle plant capital investment, percent:

\begin{tabular}{|l|c|c|}
\hline \multirow{2}{*}{ Portion of IGCC Plant } & \multicolumn{2}{c|}{ Type of Blowing } \\
\cline { 2 - 3 } & Oxygen & Air \\
\hline Power Generation & 38.75 & 40.25 \\
\hline Oxygen Plant & 15.85 & - \\
\hline Gasifiers & 5.80 & 11.60 \\
\hline Syngas Cooling & 3.30 & 6.55 \\
\hline Fuel Preparation and Feed & 5.65 & 5.65 \\
\hline Desulfurization & 5.95 & 11.50 \\
\hline Particulate Removal & 5.35 & 7.45 \\
\hline Other Expenditures & 19.30 & 19.40 \\
\hline Total & 100.00 & 102.40 \\
\hline
\end{tabular}

Basic characteristics of IGCC TPS with 600-700-MW CC unit using Kansk-Achinsk coal are shown in Table 23. The comparison with alternative PC TPS is given below: 


\begin{tabular}{|l|c|c|c|c|}
\hline \multirow{2}{*}{ Param } & \multicolumn{2}{|c|}{ Commercial PC 800MW } & \multicolumn{2}{c|}{ IGCC } \\
\cline { 2 - 5 } & $\begin{array}{c}\text { Without }_{\text {De-SO }_{x}} \\
\text { De-NO }_{x}\end{array}$ & $\begin{array}{c}\text { With } \\
\text { De-SO }_{x} \\
\text { De-NO }_{x}\end{array}$ & $\begin{array}{c}\text { Oxygen- } \\
\text { Blown } \\
\text { (Base) }\end{array}$ & $\begin{array}{c}\text { Air } \\
\text { Blown }\end{array}$ \\
\hline Nominal Efficiency, Percent & 38.50 & 37.60 & 42.50 & 43.50 \\
\hline Mean Annual Efficiency, Percent & 38.07 & 37.28 & 42.17 & 43.23 \\
\hline $\begin{array}{l}\text { Mean Annual Specific Standard } \\
\text { Fuel Consumption, g/KwH }\end{array}$ & 323.10 & 329.90 & 291.70 & 284.50 \\
\hline Relative Specific Investment Cost & 0.925 & 1.118 & 1.000 & 1.024 \\
\hline Relative Average Electricity Cost & 0.962 & 1.159 & 1.000 & 0.962 \\
\hline Specific Emissions, mg/MI: & & & & \\
\hline \multicolumn{1}{|c|}{ NO $_{x}$} & $600(325)$ & $200(80)$ & $40^{*}(30)$ & $30^{*}(25)$ \\
\hline \multicolumn{1}{|c|}{ SO $_{x}$} & $600(235$ & $300(120)$ & $3.5^{*}(2.5)$ & $10^{*}(8)$ \\
\hline Particulate Matter & $150(60)$ & $50(20)$ & $0.7^{*}(0.6)$ & $0.7^{*}(0.6)$ \\
\hline
\end{tabular}

* at $\mathrm{O}_{2}=15$ percent as it is adopted for GT.

As a prototype for a full-scale oxygen-blown IGCC plant, a demonstration plant has been designed with K-A coal gasification based on a $100-130 \mathrm{MW}$ gas turbine/generator combined with heat generation of $230-280 \mathrm{MWt}$ [35].

Conceptual designs have been made for the gasification plant including the PC feed system; the air separation plant; the gasifier; convective syngas coolers; gas/gas heat exchanger and desulfurization equipment, e.g., Selexol, Klaus, etc.

To validate the technical solutions, pilot test were made of the kinetics of entrained-flow PC gasification, industrial test of fines filters and pilot project for testing the lockhopper equipment to feed PC to the gasifier and coal-derived syngas firing in the gas turbine combustor. 


\section{Appendix}

\section{IGCC Equipment}

\section{Gas Turbine}

The GTE-200 gas turbine was designed some years ago by LMZ. This is a simple-cycle, single-shaft unit.

The GT as a unit includes an axial compressor, a turbine and a combustion section consisting of 14 combustor cans. It layout is like that depicted in Figure 11. The overall dimensions of the machine $-16.6 \mathrm{~m} \times 5.0 \mathrm{~m} \times 5.1 \mathrm{~m}$, and it weight is $210 \mathrm{t}$ - allow it to be transported by railroad car as a single assembled unit. The compressor flow path is identical to that of the GTE-150 GT which is now on line. Adding two compression stages increases the compression ratic from 13.0 to 15.6 at the same air flow rate of $630 \mathrm{~kg} / \mathrm{s}$.

The GTE-200 is designed to operate on clean liquid fuel and natural gas. Operation on lowcalorie syngas will require redesign of the combustors.

At the time the GTE-200 was designed, LMZ had no experience with large, high-temperature GT. Because of this, the design was a conservative one, and the possibilities of upgrading it performance have been considered in designing the IGCC plant. The machine data at ISO conditions using liquid fuel are shown below: 


\begin{tabular}{|l|c|}
\hline GT type & GTE-200 \\
\hline Designer & LMZ \\
\hline Output, $\mathrm{MW}$ & 198 \\
\hline Efficiency, Percent & 34.6 \\
\hline Pressure Ratio & 16.2 \\
\hline Turbine Inlet Temperature, ${ }^{\circ} \mathrm{C}$ & 1,250 \\
\hline Turbine Outlet Temperature, ${ }^{\circ} \mathrm{C}$ & 557 \\
\hline Overall Dimensions, $\mathrm{m}:$ & \\
\hline \multicolumn{1}{|c|}{ length: } & 15.6 \\
\hline width: & 5.0 \\
\hline height: & 5.1 \\
\hline Weight of $\mathrm{GT}, \mathrm{t}$ & 350.0 \\
\hline
\end{tabular}

The table below present basic characteristics of the GTE-200 GT unit using syngas produced in a steam-air blown gasifier. Gasifier air is obtained by extraction from the GT compressor in an amount equal to 75 percent of the fuel gas supplied to the combustor:

\begin{tabular}{|l|c|c|}
\hline Ambient Temperature, ${ }^{\circ} \mathrm{C}$ & -5 & +15 \\
\hline Turbine Inlet temperature, ${ }^{\circ} \mathrm{C}$ & 1,250 & 1,250 \\
\hline Pressure Ratio & 19.0 & 16.9 \\
\hline Compressor Air Flow, kg/s & 692.2 & 608.4 \\
\hline GT Output, MW & 250.0 & 206.3 \\
\hline Fuel Gas Consumption, $\mathrm{kg} / \mathrm{s}$ & 174.2 & 150.9 \\
\hline GT Efficiency, Percent & 33.7 & 32.1 \\
\hline Turbine Outlet temperature, ${ }^{\circ} \mathrm{C}$ & 547.6 & 568.3 \\
\hline Exhaust gas Flow, $\mathrm{kg} / \mathrm{s}$ & 730.8 & 641.1 \\
\hline
\end{tabular}




\section{Heat-Recovery Boiler (HRSG)}

The design of the HRSG is illustrated in Figure 43. It is of the drum type, with multiple forced circulation. The heating surfaces are layed out in a tower configuration with countercurrent flow in the economizer and superheating sections and cocurrent flow in the evaporative section. The GT exhaust enters the boiler at the botton. The element are arranged in the order of: HP superheater, reheater, HP evaporator, HP economizer, LP superheater, LP evaporator and LP economizer. The feedwater is supplied to the LP circuit and the HP circuit is fed from the LP drum.

Part of the LP steam is directed to steam dryers located in the fuel preparation section, with the condensate returned to the ST condenser.

The HRSG working dimensions are: gas duct size $11,900 \times 11,900 \mathrm{~mm}$, the tube axis height is $25,100 \mathrm{~mm}$. The outide dimensions are: $13,500 \times 13,500 \mathrm{~mm}$ in plan, $34,110 \mathrm{~mm}$ overall height.

All of the heating surfaces feature tubes with cross-band fins. The weight is about $1,700 \mathrm{t}$. The gas path pressure drop at design conditions and $-5^{\circ} \mathrm{C}$ ambient temperature is $2.5 \mathrm{kPa}$. The stack gas temperature is $95-100^{\circ} \mathrm{C}$.

\section{Steam Turbine}

The steam turbine was selected to compliment the two HP and LP circuit and live steam flows varying with ambient temperature as follows: within $-30^{\circ} \mathrm{C}$ to $+30^{\circ} \mathrm{C}$ the mass flow rate of the live steams varies by 20 percent, from $640 \mathrm{t} / \mathrm{h}$ to $520 \mathrm{t} / \mathrm{h}$. As a consequence of simultaneous change in the live steam temperature, the change in volumetric flow is only 12 percent.

At a design ambient temperature of $-5^{\circ} \mathrm{C}$, the ST has the following characteristics: 


\begin{tabular}{|l|c|}
\hline HP Live Steam Flow, $\mathrm{t} / \mathrm{h}$ & 580 \\
\hline HP Live Steam Temperature, ${ }^{\circ} \mathrm{C}$ & 515 \\
\hline HP Live Steam Pressure, $\mathrm{MPa}$ & 12.75 \\
\hline Steam Pressure after Reheater, $\mathrm{MPa}$ & 2.20 \\
\hline Steam Temperature after Reheater, ${ }^{\circ} \mathrm{C}$ & 460 \\
\hline LP Steam Flow, $\mathrm{t} / \mathrm{h}$ & 120 \\
\hline LP Steam Temperature, $^{\circ} \mathrm{C}$ & 240 \\
\hline Condenser Pressure, $\mathrm{kPa}^{\circ}$ & 5 \\
\hline Condenser Flow, $\mathrm{t} / \mathrm{h}^{\circ}$ & 550 \\
\hline ST Output, $\mathrm{MW}$ & 240 \\
\hline
\end{tabular}

With 355-MW heat delivery for heating purposes, the output of the turbine drops to $167 \mathrm{MW}$. The ST has two cylinders: a combined HP and IP cylinder and a two-stream LP cylinder.

To ensure the maintenance of adequate flows with changing ambient temperatures, sliding pressure operation is anticipated with fully-opened live steam valves: at $-30^{\circ} \mathrm{C}$ the pressure increases to $13.8 \mathrm{MPa}$, at $+30^{\circ} \mathrm{C}$ it drops to $12.1 \mathrm{MPa}$. The design cooling water temperature is $20^{\circ} \mathrm{C}$.

\section{Gasifiers}

The characteristic data of the selected coals is depicted in Table 31 . The design of the moving-bed gasifier appears in Figure 38, and that of the entrained-flow gasifier with cooling by back-mixing syngas in Figure 40. The convective gas cooler is shown in Figure 39.

The composition and some parameters of the coal-derived combustible gas (syngas) are given in Table 32.

Over 70 percent of the ash is removed from the gasifiers as liquid slag. The dust content of the raw syngas is $400 \mathrm{~g} / \mathrm{m}^{3}$ with the air-blown configuration $\left(11.5 \mathrm{~kg} / \mathrm{m}^{3}\right.$ density at operating conditions), and $765 \mathrm{~g} / \mathrm{m}^{3}$ in the oxygen-blown configuration. 
The removal of particulates in the gas path is done by cyclones ( 2 for the air-blown and 1 for the oxygen-blown). Polishing is done in filters with $0.3 \mathrm{~m}$ diameter $\times 4 \mathrm{~m}$ longceramic element. The gas dust content at the filter outlet is $2.5-6.5 \mathrm{mg} / \mathrm{m}^{3}$.

The syngas desulfurization is carried out in fluidized-bed reactors using 4 screens located at different levels of the $18 \mathrm{~m}$ high and $4 \mathrm{~m}$ diameter column. The IGCC with air-blown gasification requires 8 while only 4 are required for the oxygen-blown application. The sorbent is regenerated in the fluidized-bed furnace at temperatures below $800{ }^{\circ} \mathrm{C}$. The bed where heat is released during regeneration is water-cooled. The heat exchange surfaces arrabged in the bed are switched between steam and water as required. The regeneration gases contain 4-6 percent $\mathrm{SO}_{2}$. The spent regeneration gases are used in the production of sulfuric acid. A schematic of the cleaning system is shown in Figure 41.

Some parameters of a 600 to $700 \mathrm{MW}$ unit desulfurization system designed with 100 percent $\mathrm{H}_{2} \mathrm{~S}$ margin in the raw syngas are illustrated below:

\begin{tabular}{|l|c|c|}
\hline & Air-Blown & Oxygen-Blown \\
\hline Syngas Flow, $\mathrm{kg} / \mathrm{s}$ & 300 & 132 \\
\hline Flow at Operating Conditions, $\mathrm{m}^{3} / \mathrm{s}$ & 26.2 & 13.7 \\
\hline $\mathrm{H}_{2} \mathrm{~S}$ Content, Percent (Volume) & 0.1 & 0.2 \\
\hline $\mathrm{H}_{2} \mathrm{~S}$ Amount, $\mathrm{kg} / \mathrm{s}$ & 2.16 & 2.26 \\
\hline Reactor Cross Section Area, $\mathrm{m}^{2}$ & 100.0 & 52.8 \\
\hline Number of reactors & 8 & 4 \\
\hline Mass of Circulating Sorbent, $\mathrm{t}$ & 80 & 44 \\
\hline
\end{tabular}

\section{Air Separation Plant}

Oxygen is produced in the air-separation plant by distillation of liquified air. The IGCC employs the Kt-70 plant designed and manufactured on a special order by the NPO "Kriogenmash." This plant has the following characteristics: 


\begin{tabular}{|l|c|}
\hline Inlet Air Pressure, Bar & 6.56 \\
\hline Inlet Air Temperature, ${ }^{\circ} \mathrm{C}$ & 60 \\
\hline Air Flow, $\mathrm{m}^{3} \mathrm{~h}$ (normal) & 350,000 \\
\hline Production 95 Percent $\mathrm{O}_{2}$ at 1.03 Bar (Absolute), $\mathrm{m}^{3} / \mathrm{h}$ & 66,000 \\
\hline
\end{tabular}

The tumdown capability of this plant is to 70-80 Percent of nominal design value. Startup from cold condition takes 4-5 hours. The plant is designed for 1-2 year continuous operation with time between overhauls of 8 years.

The energy requirement are $0.35 \mathrm{kWh} / \mathrm{m}^{3}$ of produced oxygen. Other gases are co-produced with the oxygen in this plant, as follows: $30,000 \mathrm{~m}^{3} / \mathrm{h}$ of Nitrogen at $1.0 \mathrm{Bar}$ absolute, $9.57 \mathrm{~m}^{3} / \mathrm{h}$ of 40 percent concentration Neon-Helium mixture at $0.5 \mathrm{Bar}$ absolute and $130 \mathrm{~m} / \mathrm{h}$ of 0.2 percent concentration Krypton-Xenon mixture.

The overall size of the air separation plant are:

Air Separation Unit: $20 \mathrm{~m} \times 13.6 \mathrm{~m} \times 44.45 \mathrm{~m}$.

Regenerator Unit: $22.65 \mathrm{~m} \times 16 \mathrm{~m} \times 16 \mathrm{~m}$

Weight of the Plant: $1,210 \mathrm{t}$

\subsection{TPS with Fluidized-Bed Gasification CCP Project}

The Central Boiler/Turbine Institute (TsKTI, St. Petersburg) and VNIPIEnergoprom Design Institute (Moscow) have developed a TPS project with a $250 \mathrm{MW}$ CCP and gasification of Kuzn coal in a fluidized-bed, steam/air-blown gasifier.

The flow sheet for the highly-integrated CCP is illustrated in Figure 48. The air for the gasifier is extracted from the GT compressor and boosted to gasifier pressure of $2.0 \mathrm{MPa}$ by an auxiliary compressor arranged on a common shaft with the expansion turbine which operates on clean syngas and the auxiliary steam turbine balancing the output of the CC block. Steam for the gasifier is extracted from the HP section of the ST. Prior to entering the gasifier, it is superheated in one of the sections of the convective raw syngas cooler. Cooling of the raw syngas ahead of low-temperature gas cleanup, and it subsequent reheating after sulfur removal are done with minimal wastage of sensible heat along with production of HP saturated steam. 
The design of the gasifier is illustrated in Figure 49. The octogon-shaped reaction chamber is formed by the waterwall tube membranes transitioning into the the steam generator.multiple forced-circulation loop. To make the gasifier path leak-tight and protect the gasifier external shell from the effect of the reaction heat, the steam extracted from the HP side of the ST is fed through the space between the gasifier shell and the waterwall membrane. Some gasifier parameters and characteristics are shown in Table 33.

The power island on a CC with supercharged steam generator (SSG) includes a GTE-45-2 GT unit of KhTZ manufacture (See section 2.3), T-180 extraction ST made by LMZ and two SSGs of TKZ design. It sectional view is shown in Figure 9. The GT is connected with the SSGs, arranged symmetrically at both sides, by double-walled duct. The air extracted from the GT compressor is directed to the SSG through the annular space between the walls of the duct. The outer wall is cold and the inner wall contains the combustion product returning to the GT. Each SSG is fed by the syngas from it own gasification train which consist of the fuel lockhopper system, gasifier, gas coolers, gas cleaning and preheating system and turboexpander. Natural gas can be fired in the SSG, which ensures operability of the TPS when the gasifiers are down.

The schematic of the coal preparation system for a fluidized-bed gasifier is shown in Figure 50.

The fuel is fed by the station-wide fuel handling system to the raw coal hoppers after coal crushing. For the fluidized-bed gasifier, coal lumps shall not exceed $20 \mathrm{~mm}$ in size and the amount of the $<1 \mathrm{~mm}$-sized fines shall be 15 percent maximum. For this reason, the coal is again crushed in a special crusher which produces minimum fines. After crushing, the coal is dried to 10-12 percent moisture content. The GT exhaust gas is used as a drying agent. Fine fractions are entrained out of the fluidized-bed drier with the drying agent and are separated in the cyclone, with final removal in an ESP. The dust is combined with binding agent and granulated to the $3-10 \mathrm{~mm}$ size. The granules are then predried and strengthened. The crushed coal and the granules are fed to the gasifier through a lockhopper system, driven by syngas taken from before the gas heater, additionally cooled and compressed [42].

The syngas is cooled and heated in several exchangers. Some of the operating data for these exchangers is given below: 


\begin{tabular}{|c|c|c|c|c|c|}
\hline No. of Cooler/Heater & Gas Duct & 1 & 2 & 3 & 4 \\
\hline Gas Temperature, ${ }^{\circ} \mathrm{C}$ & & & & & \\
\hline Inlet & 950 & 971 & 522 & 410 & 160 \\
\hline Outlet & 917 & 522 & 410 & 220 & 335 \\
\hline
\end{tabular}

The $16 \mathrm{MPa}, 346^{\circ} \mathrm{C}$ boiler water from the forced-circulation loop of the SSG is used as a cooling agent. The temperature of the tubes in this case is $400-410^{\circ} \mathrm{C}$ maximum. They can be fabricated of low-alloy steel.

The gasifier shell is protected from the effect of high temperatures and the aggressive attack of the syngas by the water-wall membrane. The gas duct and the walls of gas cooler No.1 are protected in the same fashion. The gas cooling path includes 3 additional convective cooling sections operating at gas velocities of $6-7 \mathrm{~m} / \mathrm{s}$ which ensures self-cleaning of the surfaces withour tube erosion. The 3 rd Section incorporates a tube bundle whose purpose is to superheat the gasifier steam to $450^{\circ} \mathrm{C}$. It has austenitic tubes. The walls of the other gas coolers, operating at syngas temperatures no greater than $522^{\circ} \mathrm{C}$, are unprotected. For wet cleaning, the temperature of the syngas is reduced to $160^{\circ} \mathrm{C}$, and after cleaning increases to $330-350^{\circ} \mathrm{C}$, at which point it is fed to the expansion turbine and thence to the SSG burners. All gas coolers have $3.8 \mathrm{~m}$ diameter outer shells assuring transportation by normal means as assembled unit. The shell length is $17-33 \mathrm{~m}$.

The coarse cleaning of the syngas is done by cyclones in two stages. The first stage is after gas cooler number 1 and occurs at $500-550^{\circ} \mathrm{C}$. The cleaning efficiency of the first stage is $65-70$ percent. The second stage is located after gas cooler number three at $210^{\circ} \mathrm{C}$. The efficiency of this stage is 90 percent.

The fine cleaning of the syngas to a particle content of less than $10 \mathrm{mg} / \mathrm{m}^{3}$ (under normal conditions) is by washing in a venturi scrubber followed by a cyclone mist eliminator.

The greater part, i.e., $70-80$ percent, of sulfur removal occurs in the fluidized bed where limestone or dolomite sorbent is injected along with the coal feed. The test trains, which account for about 5-7 percent of total capacity, are incorporated in the system for dry, fine cleaning of the syngas particulates at $410^{\circ} \mathrm{C}$; dry removal of $\mathrm{SO}_{2}$ by iron ore at the same temperature; and mid-temperature, i.e., $140-160{ }^{\circ} \mathrm{C}$, catalytic $\mathrm{SO}_{2}$ removal using activated coal. When these technologies are mastered, total sulfur capture will increase to 95 percent 
and above.

Low $\mathrm{No}_{\mathbf{x}}$ emissions are ensured by:

- a considerable percentage of the nitrogen contained in the fuel is converted to ammonia in the gasifier. The ammonia is removed from the syngas by later washing.

- lower combustion temperatures of the syngas in the SSG.

One possible layout for the CCP-250 and gasification plant is shown in Figure 51.

The separate processing sections are each housed in a separate building: turbine hall (the entire CCP including SSG), fuel preparation equipment, gasification plant, additional compressor-expansion turbine, and the balance of plant equipment.

The combined cycle is arranged in a single-bay building $180 \mathrm{~m}$ long and $42 \mathrm{~m}$ wide. The building houses the steam turbine, GT, SSG and gas-water heater (HRSG) in the GT exhaust path. The deaerator and condensate feed equipment are located between the steam turbine and the GT. The maintenance sites and the through railroad track also are located in this building.

An open bay building, $39 \mathrm{~m}$ wide and $72 \mathrm{~m}$ long, shelters the two gasifiers, gas coolers and heaters, and the gas cleaning equipment.

Basic parameters of the IGCC-250 TPS and coal gasification system are shown in Tables 22 and 23. Here also are the parameters of the CCP "industrial unit" designed by TsKTI to the same process scheme but a larger and more efficient GT with an inlet gas temperature of $1,100^{\circ} \mathrm{C}$.

Test and validations for the project were conducted on the $250 \mathrm{~kg} / \mathrm{h}$ coal capacity pilot plant operating at up to $3 \mathrm{MPa}$ [43] and at the large-scale TsKTI test facility at up to $0.6 \mathrm{MPa}$ [44].

The model for the CCP-250 gasification system was reproduced at the TsKTI test facility. Gasification test were conducted on Kum bituminous coals of WS grade at flow rates from 600 to $1,100 \mathrm{~kg} / \mathrm{h}$, as well as on brown $\mathrm{K}-\mathrm{A}$ coals. The facility's gasifier vessel is $2.2 \mathrm{~m}$ in diameter and $10 \mathrm{~m}$ high. The actual reactor diameter is $800 \mathrm{~mm}$ and the syngas output is $4,500 \mathrm{~m}^{3} / \mathrm{min}$. The gasification was conducted with steam/air blast at $900-1,000{ }^{\circ} \mathrm{C}$. This 
plant facilitated the discovery and elimination of many "children's diseases" in such areas as fuel preparation and handling, startup and maintaining gasifier operation, removal of gasifier bottom ash, ensuring maintenance of non-slagging conditions, etc.

The test were conducted at the following conditions:

\begin{tabular}{|l|c|}
\hline \multicolumn{1}{|c|}{ Coal Characteristics: } & $16.9-27.4$ \\
\hline Heating Value, MJ/kg & 23.1 \\
\hline Moisture Content, Percent & $10.6-15.1$ \\
\hline Ash Content, Percent & $0.95-3.5$ \\
\hline Mean Particle Size, $\mathrm{mm}$ & $28-48$ \\
\hline Fines Content, Percent & $600-1,100$ \\
\hline Coal Consumption, $\mathrm{kg} / \mathrm{h}$ & $1,220-3,100$ \\
\hline Air Flow, kg/h & $400-800$ \\
\hline Steam Flow, kg/h & $2-3$ \\
\hline Gasifier Pressure, Bar & $200-350$ \\
\hline Steam-Air Mixture Temperature, ${ }^{\circ} \mathrm{C}$ & $800-950$ \\
\hline Fluidized-Bed Temperature, ${ }^{\circ} \mathrm{C}$ & $3.45-4.9$ \\
\hline Gas Heat Value, $\mathrm{MJ} / \mathrm{m}^{3}$ & $2.7-10.0$ \\
\hline Unburned Carbon, Percent & \\
\hline
\end{tabular}

At design velocities of $1.7-2.0 \mathrm{~m} / \mathrm{s}$ and with moderate amounts of coal fines, the syngas was of normal quality and fly ash removal was acceptable.

Fuel preparation devices, such as the cutting $10 \mathrm{t} / \mathrm{h}$ crusher, fluidized-bed dryer/feeder, etc., as well as fines granulation technology were mastered on special pilot rigs. Fluidized-bed gasification of granules has been successfully conducted. 


\section{CONCLUSIONS}

\section{TERMS OF APPLICATION OF CLEAN COAL TECHNOLOGIES AT RUSSIAN TPS}

Wide use of as-mined, high-ash coals at TPS is a characteristic of Russian power generation.

Large amounts of brown coals are produced and fired at TPS. The cheapest and most promising of these in terms of future use are strongly-slagging $\mathrm{K}-\mathrm{A}$ coals.

The positive feature of the worth-while Russian coals is low sulfur content, leading to $\mathrm{SO}_{2}$ emission standard compliance. Nevertheless, the production and use of some amounts of high-sulfur coals (from the near-Moscow, Inta and Donetsk coal fields) will continue for a long period of time.

In practice, fuel standards are not strictly met. There are cases where the ash content and heating value of a coal are beyond specified limits. Many times it has been necessary to change the grade of coal supplied to some TPS or units.

No steam coal market exists in Russia and the possibility that one might eventually materialize is not generally accepted.

These conditions demand testing of the applicability of clean coal technologies for high ash fuels, brown coals with specific ash properties and the adaptability of these technologies to coals of varying properties.

The Russian climate is more severe than that in the U.S. It is traditional to employ centralized heating systems for residential and industrial premises. Over half of all fossilfueled TPS are cogeneration facilities. In terms of generation capacity, this percentage is even higher. Many of the cogeneration plants are therefore of necessity located within city areas and so the requirements for them to be reliable sources of heating as well as producing reduced emissions are foremost. The cogeneration plants employ boilers of relatively small size and capacity, e.g., 170-670 tph.

Low ambient temperatures must be taken into account in the design and installation of equipment: the opportunity to locate equipment out-of-doors is relative limited; and the technologies designed for large power units need to be tested with reference to smaller applications. 
The most important task for the Russian power industry will be life extension for older TPS in line with increased efficiency and reduced adverse environmental impact. Such TPS represent the largest market for the environmentally benign technologies.

Russian TPS typically locate 6-12 units of the same type within a common main building. While this carries certain economic advantages, e.g., ease of construction, erection and operation, such TPS layout complicates the arrangement of additional equipment during modernization to improve performance or for gas cleaning because of lack of space.

For this reason, location of pollution control equipment and the necessary additional air, fuel and gas ducting can differ greatly from the U.S. CCTP practice. Similar difficulties appear when replacing coal-fired boilers requiring more space due to things such as large-sized, external cyclones. For this reason, the CFB boilers with in-duct ash separators developed by $B \& W$ seem more attractive.

Russia has well-equipped manufacturing facilities for power-industry equipment, and organizations with highly-qualified personnel capable of accomplishing the engineering and design, construction and operation of pollution-control equipment and systems. These assets are under-utilized at present. The Russian power industry has relied upon domestic equipment meeting high standards and providing for reliable TPS operation up until now. Russia uses its own norms and standards. Even though, in some areas Russian engineering fell behind current practice, e.g., GT, CCP, environmental protection and I\&C systems, the decision makers - managers of power systems and TPS - are mostly oriented toward Russian equipment and materials.

With this in mind, the most fruitful route toward transferring the CCTP-based U.S. technologies to Russia is joint production. with Russia, of the equipment and employment of Russian personnel to solve possible technical problems. This may require revision of the U.S. technical documentation to comply with Russian standards, materials and manufacturing technologies, and prove Russian sorbents, catalysts and other materials in the technological processes, and etc.

Finally, in transferring the technologies, it is useful to take into account today's difficult economic situation in Russia. Electricity consumption has dropped, only a small percentage of the necessary investment capital is available for retrofitting/repowering of existing capacity and construction of new TPS. Financial difficulties are a major cause of long construction times in Russia. 
Under these conditions, lower-cost technologies become more attractive, especially if they can be implemented in stages. Design and supply of shop-fabricated, modular equipment is desirable. Careful planning and organization of the construction process should be the rule. 



\section{REFERENCES}

1. Новая энергетическая политика России. Москва, Энергоатомиздат, 1995

2. ТЭК. Итоги работы 1994 года. Энергия N2 (14) февраль 1995

3. Состоліние технического уровня производства в отрасли, 1993 год. Москва, РАО"ЕЭС России", АО"Ииформэнерго", 1994

4. Развитие электроэнергетики России в период до 2010 года. Вестник электроэнергетики, 1994, $N$ 4, с.12-20

5. А.Тумановский, В.Глебов, В.Гуща Природоохранные мероприятия в энергетике России. Вестиик электроэнергетики, 1994, N 3, с.32-40

6. V.P.Glebov, A.G.Tumanivsky et al. Nature Protection in the Russian Heat Engineering. BW-VTI Workshop, Moscow, June 21-25, 1993

7. V.V.Gapeev et al. Coal Combustion at Thermal Power Stations of Russia. Symposium on Coal Fired Power Generation. The Environmental and Public Acceptance, Ankara, 30 May-June, 1995

8. R.A.Peirosyan, V.I.Gorin State-of-the-art and Prospects of Russlan Power Industry. Boiler Units of Thermal Power Plants. BW-VTI Workshop, Moscow, June 21-25, 1993

9. ПТаровые котыы большой мощности. Отраслевой каталог 20-90-07, москва, 1990

10. Котельные и турбинные установки энергоблоков мощностью 500 и 800 Мвт. Москва, Энергия, 1979

11. Б.П.Афанасьев, Р.А.Петросян, Р.Ю.Шакарян и др. О разработке котлов с циркулирующим кипящим слоем. Энергетик, 1991, N 5, с.6-8

12. А.В.Щегляев. Паровые турбины. Книга 2. Москва, Энергоатомиздат, 1993

13. Пичугин И.И., Цветков А.М., Симкин М.С. Особенности проектирования паровых турбин ЛМЗ. Теплознергетика, 1993, N 5, с.10-21

14. Левченко Е.В., Галацан В.Н., Сухинии В.П., Аркадьев Б.А. Турбины нового поколоения Нпо"Турбоатом". Теплоэнергетика, 1993, N 5, с.22-29

15. Aлексо А.И., Баринберг Г.Д. Паровые теплофикационные турбины и пути. их дальнейшего совершенствования. Tепnоэнергетика, 1993, N 5, с.5-10

16. Романов В.И. и др. Новый газотурбинный двигатель мощностью 110 МВт для стационарных энергетических установок. Теплоэнергетика, 1992, N 9. c. $15-21$

17. Орлов В.Н. Газотурбинный двигатель авиационного типа НК-37 Аля электростанций. Теплоэнергетика, 1992, N 9, с.27-31

18. Перспективы применения газовых турбин в энергетике. Теплознергетика, 1992, N 9, с.2-9

19. 'Фаворский О.Н. и др. Пути развития газотурбинных установок Аля энергетики СССР. Теплоэнергетика, 1990, N 3, с.9-14 
20. Ртищев В.В., Храбров П.В. Корсов Ю.Г. Исследования в области служебных характеристик материалов - основа повышения надежности и ресурса газовых турбин. Энергомашиностроение, 1986, N 6, с.25-30

21. Энергетическая стратегия России (Основные положения) Межведомственная комиссия по разработке программы, Москва, 1994

22. Clean Coal Teclınology Demonstration Program. U.S.Department of Energy, Program Update, 1993

23. Third Annual Clean Coal Technology Conference, Chicago, September, 6-8, 1994

24. Foreign Market for U.S.Clean Coal Technologies. Report to The U.S.Congress by the U.S.DOE, May 2, 1994

25. A.G.Tumanovsky, Yu.P.Enyakin, Yu.M.Usman, V.R.Kotler Reduction of $\mathrm{NO}_{\mathrm{x}}$ Emissions by Reburning-Process at Gas/Oil and Coal Boilers. International Workshop on Gas Reburn Teclinology, February 7-9, Malmo, Sweden

26. Энергетическое топливо СССР. Справочник, Москва, Энергоатомиздат, 1991

27. И.Я.Залкинд, В.С.Вдовченко, Э.П.Дик. Зола и шлаки в котельных топках Москва, Энергоатомиздат, 1988

28. G.G.Olkhovsky, A.G.Tumanovsky. Coal for Power Industry of Russia. The Second World Coal Institute Conference, March 24-26, 1993

29. A.Tumanovsky et al. Problems and Prospects on Coal-Fired Electricity Generation In Russia: Designing Ecologically Clean Power Stations United Nations Economic Commission for Europe, Symposium on New Coal Utilization Technologiles, Helsinki (Finland), May 10-13, 1993

30. В.В.Лисицын и др. Промышленные исследования некоторых способов подавления оксидов азота при пылеугольном сжигании углей Сибири и Казахстана. Теплоэнергетика, 1988, № 8, с.7-20

31. Л.И.Пугач и др. Концентрированная подача пыли в горелки котлов как средство снижения содержания оксидов азота. Электрические станции, 1989, No 6, c.17-20

32. Л.А.Кесова и др. Опыт эксплуатации и исследования системы пылеподачи с высокой концентрацией пыли при сжигании АШ. Теплоэнергетика, 1992, № 3, с.57-61

33. Л.И.Кропп, А.М.Зыков. Перспективы использования нейтрализующих свойств золы при очистке дымовых газов. Электрические станции, 1992, № 1, c.46-51

34. V.V,Gapeev, I.I.Nadyrov, I.A. Novozhilov and A.G.Tumanovsky. Works Conducted In Russia on Dense and Clrculating Fluidized Bed Solid Fuel Combustion. Symposium on Coal-Fired Power Generation. The Environment and Public Acceptance, Ankara, 30 May-June, 1995 
35. Экологически чистая энергетика (концепция и краткое описание проектов Государственной научно-технической программы). Министерство науки, высшей школы и технической политики Российской Федерации. Москва, 1993

36. В.Г.Соколовский, В.В.Гапеев. Экологически чистая ТЭС га угле будущее теплоэнергетики (итоги конкурса). Теплоэнергетика, 1989, № 8, c.2-4

37. М.С.Пронин, М.Я.ர்роцайло и др. Разработка и экспериментальная проверка новой технологии и оборудования экологически чистой ТЭС на канско-ачииıских углях. Теплоэнергетика, № 2, 1995, с.12-16

38. Р.А.Петросян, А.Н.Алехнович и др. Экологически чистые электростанции на экибастузском угле. Теплоэнергетика, № 6, 1991, с.12-18

39. G.Riabov. The State of Boiler Technics Using Solid Fuels in Order to Get Heat and Energy in Boiler Rooms of District, Central Heating Systems and Industry in Russia. U.N.Economic Commission for Europe; Workshop on Development of Clean Small-Size Boilers for Industrial, Households and Farming Sectors, Szczyzk, Upper Silezia (Poland), April 5-7, 1995

40. Гильде Е.Э., Гудкин М.З., Пилягин В.Ф., Стропус В.В. Опытнопромышленный котел с циркулирующим кипящим слоем паропро́изводительностью 500 т/ч. Тяжелое машиностроение, № 2.

41. П.А.Березинец, В.И.Горип и др. Перспективные парогазовые установки с газификацией канско-ачинского угля для экологически чистой Березовской ГРЭС-2. Теплоэнергетика, № 6, 1991, с.18-24

42. Проектирование парогазовых ТЭЦ с внутрицикловой газификацией твердого топлива. Сб.Трудов ВНИПИЭнергопрома, Москва, 1985

43. Черепков И.И., Шафир Г.С., Никитина Т.В. Получение синтетического газа из углей. Химия твердого топлива, 1981, о 1, с.3-7

44. Чавчанидзе Е.К., Шестаков Н.С. Исследование процесса газификации в кипящем слое под давлением на опытной установке. Проблемы тепло- и массообмена в современњых технологиях сжигания и газификации твердого топлива. Минск, 1994, ч.1, с.110-116 



\section{ACRONYMS AND ABBREVIATIONS}

A

ABBCE

$A C$

AFBC

AOFA

ASME

B\&W

BGL

BEZM

BIKZ

Bit., bitum.

BKZ

$\mathrm{Br}$.

CCP

CCTP

$\mathrm{CE}$

CFBC

ChZEM

COREX $^{\circ}$

CWS

CZD/FGD

$\mathrm{DCh}$

de-NO ${ }_{x}$

de- $-\mathrm{SO}_{x}$

DOE

EAS

EERC (E\&ER Corp)

EF

Ekib

EPA

$\mathrm{E}^{-\mathrm{SO}_{\mathrm{x}}}$

ESP

ETM

FB

FBC anthracite; air (table 17) ABB Combustion Engineering Inc. Anthracite Culm Atmospheric Fluidized-bed Combustion Advanced Over-Fire Air American Society of Mechanical Engineers Babcock \& Wilcox Company British-Gas-Lurgi (technology) Belgorod Boiler Works Biysk Boiler Works bituminous (kind of coal) Barnaul Boiler Works brown (kind of coal) Combined Cycle Plant Clean Coal Technology Demonstration Program of U.S. Department of Energy Combustion Engineering Inc. Circulating Fluidized-Bed (technology) Chekhov Power Engineering Works (near-Moscow) a registered trademark of Deutsche Voest-Alpine Industrieanlagenbau GmBH Coal-Water Slurry Confined Zone Dispersion/Flue Gas Desulfurization process Dow Chemical $\mathrm{NO}_{x}$ removal technology $\mathrm{SO}_{x}$ removal technology U.S. Department of Energy Electrosila Works (St.Petersburg) Energy and Environmental Research Corporation Entrained-Flow Ekibastuz coal field U.S. Environmental Protection Agency $\mathrm{SO}_{\mathbf{x}}$ Semidry Removal Technology in the Inlet of ESP Electrostatic Precipitator Electrotyajmash Works (Kharkov)

Fluidized Bed (table 17) Fluidized-Bed Combustion (technology) 
GE gaseous coals (kind of coal) General Electric Co.

GR-LNB

GSA

GT

HD

HHV

HP

I\&C

IGCC

IP

ISO

K-A

KhTZ

KRW

KTZ

Kuzn

L

LD

LHV

LIDS

LIFAC

LF

Lig., Lign.

LIMB

LMZ

LNB

LNCB

LNCFS

LP

MB

MPC

N. Caucasus
Type of $\mathrm{SO}_{2}$ and $\mathrm{NO}_{x}$ Reduction System (Limestone Injection Multistage Bumer) Leningrad Metal Works (St. Petersburg) Low-NO $\mathrm{N}_{x}$ Burner Low-NO ${ }_{x}$ cell burner Low-NO $\mathrm{N}_{\mathrm{x}}$ Concentric Firing System

Low Pressure Moving-Bed (table 17)
Maximum Permissible Concentration

Northem Caucasus 
N-W

NZL

OMTI

P.C., pc

PCFB

Pech

PermTPS

PFBC

R\&D

SCR

SETM

SNCR

SNOXTM

SNRBTM $\mathrm{SO}_{\mathrm{x}}-\mathrm{NO}_{\mathrm{x}}-\mathrm{R}_{\mathrm{ox}}-\mathrm{B}_{\mathrm{ox}}$

SR ( )

SSG

ST

Subbitum.

SZTM

T

TKZ

TM

TMZ

TPS

TsKTI

TWR
North-West (regions of Russia)

Nevsky Works (St. Petersburg)

Trademark of the Synthetic Fire-Resistant Oil

Pulverized Coal combustion

Pressurized Circulating Fluidized Bed (technology)

Pechora coal field

Permskaya Thermal Power Station Pressurized Fluidized-Bed Combustion

Research and Development

Selective Catalytic Reduction

Sibelektrotyajmash, (Novosibirsk)

Selective Non-Catalytic Reduction

Type of combined $\mathrm{NO}_{\mathrm{x}}$, and $\mathrm{SO}_{\mathrm{x}}$ Reduction System Combined $\mathrm{NO}_{x}, \mathrm{SO}_{x}$ and particulate Reduction System of $\mathrm{B} \& \mathrm{~W}$

U-GAS ${ }^{\circ}$ Registered Trademark of the Institute of Gas Technology (gasification technology) VA

VNIIAM Voest-Alpine

VNIPIEnergoprom

VTI

WS, WS1, WS2

YuTZ

$\mathrm{ZIO}, \mathrm{ZiO}$

Power Station Equipment Manufacturing Works (Syzran', Middle Volga) Tampella and Gas Research Institute (only for table 17)

Taganrog Boiler Manufacturing Works

Trademark

The Urals Turbomotor Works (Ekaterinburg)

Thermal Power Station

Central Boiler/Turbine Institute (St. Petersburg)

U.S. Company

Research Institute (Moscow)

Designing Institute (Moscow)

All-Russia Thermal Engineering Institute (Moscow)

weakly sintering coals (kinds of coal)

Gas Turbine Manufacturing Works in Nikolaev (The Ukraine)

Podol'sk Boiler Manufacturing Works

\section{Abbreviations}



A, \%
ash content
$\mathrm{Al}_{2} \mathrm{O}_{3}$
bar
aluminum oxide
$10^{9}$
unit of pressure
BTu
billion
${ }^{\circ} \mathrm{C}$
$\mathrm{C}$
CO
British Thermal unit
degrees centigrade carbon; cold (table 17) carbon monoxide carbon dioxide
$\mathrm{Ca}$ calcium
ca.
circa, approximately
$\mathrm{CaCO}_{3}$
calcium carbonate, calcitic limestone
cal
$\mathrm{CaO}$
calorie, unit of heat
calcium oxide, lime
$\mathrm{Ca}(\mathrm{OH})_{2}$
$\mathrm{CH}_{4}$
$\mathrm{CaS}$
$\mathrm{Ca} / \mathrm{S}$
$\mathrm{CaSO}_{3}$
$\mathrm{CaSO}_{4}$
$\mathrm{CaO} / \mathrm{SO}_{2}$
$\mathrm{Cl}$
molar ratio of calcium oxide to sulphur dioxide chlorine
$\mathrm{Cr}$ chromium
d
daf
dry ash free
S/kW
$\$ / t$
dollars per kilowatt dollars per ton ferric dioxide $\mathrm{g} / \mathrm{kWh}$
$\mathrm{g} / \mathrm{m}^{3}$
Gcal
GW
$\mathrm{H},\left(\mathrm{H}_{2}\right)$
$\mathrm{H}_{2} \mathrm{O}$
water
$\mathrm{H}_{2} \mathrm{~S}$
$\mathrm{H}_{2} \mathrm{SO}_{4}$ hydrogen sulphide
sulphuric acid
ur(s) - unit of time hydrogen sulphide
sulphuric acid
our(s) - unit of time
h, hr(s) hydrogen sulphide
sulphuric acid
hour(s) - unit of time
gram per kilowatt-hour
gram per cubic meter gigacalorie, $10^{9}$ calories gigawatt, $10^{9}$ watts hydrogen; hot (table 17) 
$\mathrm{h} / \mathrm{y}$

$\mathrm{He}$

J

K

$\mathrm{K}_{2} \mathrm{O}$

$\mathrm{kcal} / \mathrm{kg}$

$\mathrm{kg} / \mathrm{s}$

kilo

$\mathrm{kJ} / \mathrm{kWh}$

km

$\mathrm{kPa}$

$\mathrm{Kr}$

$\mathrm{kV}$

$\mathrm{kW}$

kWh

$\mathrm{kWh} / \mathrm{y}$

$\mathrm{M}$

$\mathrm{m}, \mathrm{m}^{2}, \mathrm{~m}^{3}$

$\mathrm{m}^{3} / \mathrm{h}$

$\mathrm{m}^{3} / \mathrm{s}$

mega

$\mathrm{mg} / \mathrm{m}^{3}$

$\mathrm{mg} / \mathrm{MJ}$

$\mathrm{MgO}$

$\mathrm{MgSO}_{3}$

$\mathrm{MgSO}_{4}$

MJ

$\mathrm{MJ} / \mathrm{kg}$

$10^{6}$

m

mm

MnO

$\mathrm{MPa}$

MW

MWe

MWt

$\mathrm{MW} / \mathrm{m}^{3}$ hours per year helium

Joule

potassium

potassium oxide

kilocalorie per kilogram

kilogram per second

1,000

kilojoule per kilowatt-hour

kilometer

kilopascale; unit of pressure

krypton

kilovolt

kilowatt

kilowatt-hour

kilowatt-hour per year

mixture

meter, square meter, cubic meter

cubic meter per hour

cubic meter per second million, $10^{6}$

milligram per cubic meter milligram per megajoule

magnesium oxide

magnesium sulphite magnesium sulphate megajoule megajoule per kilogram million micrometer, micron millimeter manganese oxide megapascale; unit of pressure megawatt megawatt electric megawatt thermal megawatt per cubic meter 


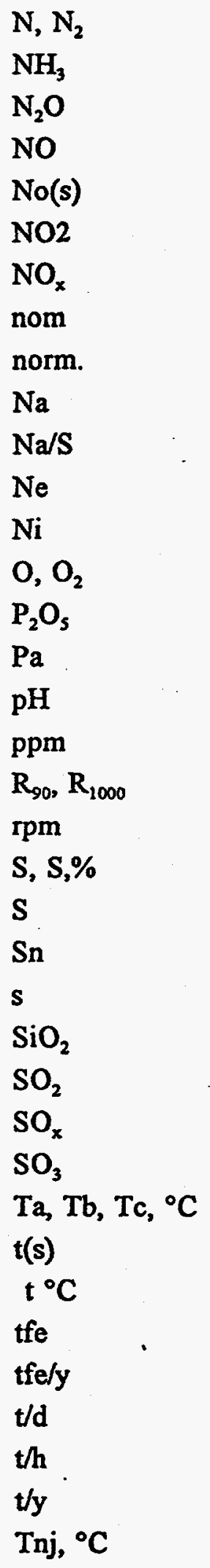

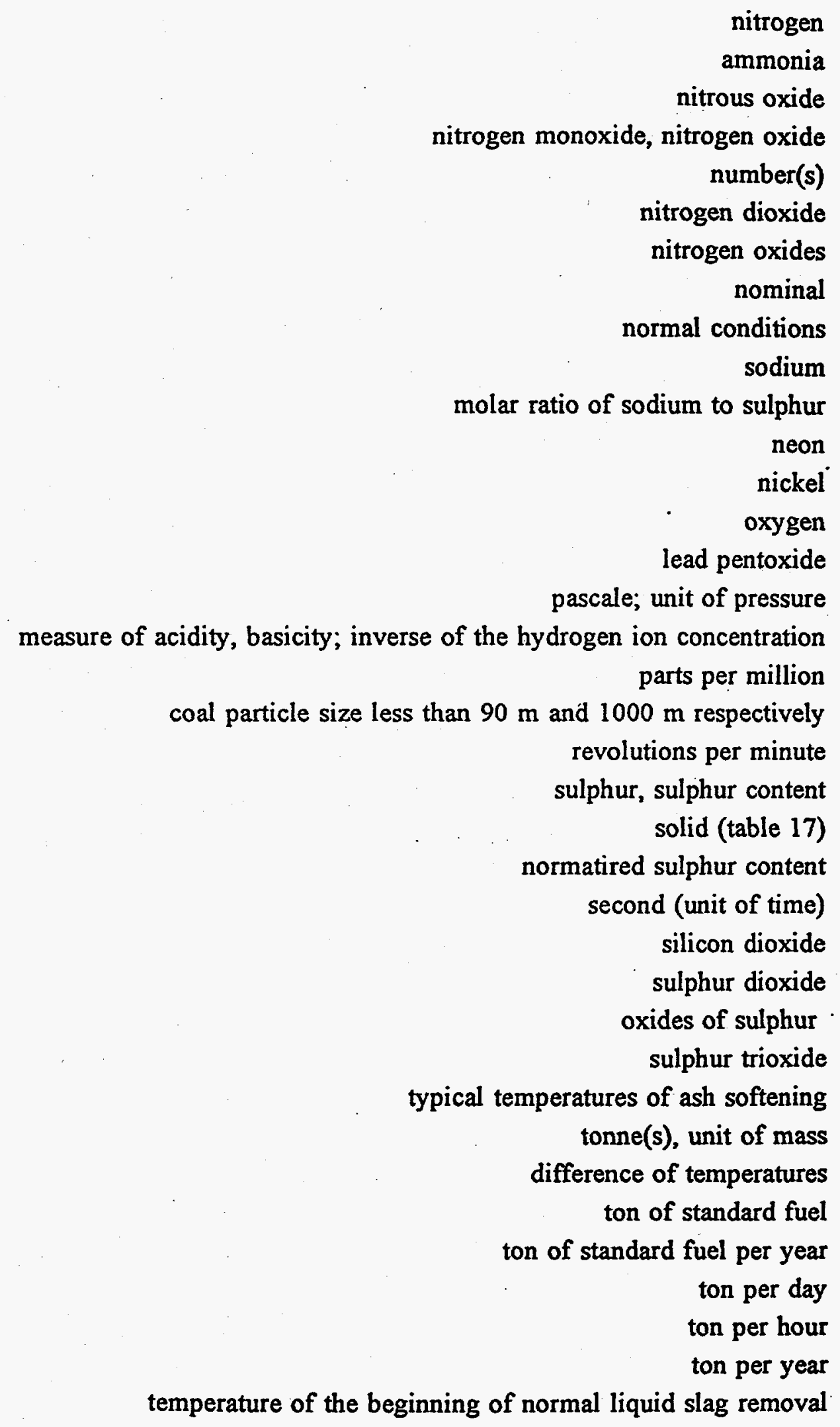


$\mathrm{TiO}_{2}$

thou $\mathrm{m}^{3} / \mathrm{h}$ (min)

thou hrs

thou hrs/yr

$\mathrm{W}, \%$

w/o

$\mathrm{Xe}$

$\mathrm{Y}, \mathrm{yr}, \mathrm{yrs}$

(SR) titanium dioxide thousand cubic meter per hour (minute) thousand of hours thousand hours per year moisture without xenon year, years excess air efficiency

Types of Russian PC Boilers

E-500

P-57, P-67

TPE-214A, TPE-216,

TPP-312A, TPP-804

Types of Russian Large Steam Turbines

K-1200-240, K-800-240, K-300-240, K-210-130,

PT-80/100-130/13

K-500-240, K-160-130

T-250-240, T-185-130, T-100-130

Types of Russian Gas Turbine Units

GTE-200, GTE-150

GTG-110

GTE-45

GTN-25

GTN-25, GTN-16 type of BKS's boiler (natural circulation, steam output $500 \mathrm{t} / \mathrm{h}$ ) trademarks of ZIO's boilers trademarks of TKZ's boilers types of LMZ's steam turbines types of KhTZ's steam turbines types of TMZ's steam turbines

Types of CIS marine and aeroderivative GT Units

GT-15, GT-16, GT-25

RD-29-300

AL-31STE manufactured by LMZ manufactured by Mashproject manufactured by KhTZ manufactured by NZL output $30.0 \mathrm{MW}$ ) manufactured by TMZ manufactured by Mashproject and YuTZ manufactured by Tushino manufactured by "Saturn" 
Types of Russian CCPS

CCP-450T (V94.2 GT type)

CCP-325 (GTG-110 GT type)

CCP-80 (NK-37)
GT manufactured by Siemens-LMZ

GT manufactured by Mashproject GT manufactured by "Trud"

Marks of Russian Boiler-Turbine Steels and Alloys

$12 \mathrm{X} 18 \mathrm{~N} 12 \mathrm{~T}$

12X1MF

ET607A, EP-927

EI893L, EP539LMU, TsL-2, Ts-4 (ZMI-4U), TsL5(7), ZMI-3, TsNK-7NK, JSBK-RS, JSBK-NK high-alloyed $\mathrm{Cr}-\mathrm{Ni}$ austenitic steel low-alloyed perlitic steel deformed GT alloys casting GT alloys 
TABLES

T-1 
T-2 
Table 1

NOx Specific Emission Norms for Boilers to be Installed at TPS before 01.01.2001

\begin{tabular}{|c|c|c|c|c|}
\hline \multirow{2}{*}{$\begin{array}{l}\text { Boiler thermal } \\
\text { output, } \mathrm{MW}\end{array}$} & \multirow[t]{2}{*}{ Fuel fired } & \multicolumn{3}{|c|}{ Units of measurement } \\
\hline & & $g / M J$ & $\mathrm{~kg} / \mathrm{tfe}$ & $\begin{array}{c}\mathrm{mg} / \mathrm{m}^{3} \text { of dry gas } \\
\quad(=1.4)\end{array}$ \\
\hline \multirow{8}{*}{$100-299$} & Gas & 0.05 & 1.46 & 150 \\
\hline & Fuel oil & 0.10 & 2.93 & 290 \\
\hline & Brown coal: & & & \\
\hline & dry-bottom & 0.12 & 3.50 & 320 \\
\hline & wet-bottom & 0.13 & 3.81 & 350 \\
\hline & Bituminous coal: & & & \\
\hline & dry-bottom & 0.17 & 4.98 & 470 \\
\hline & wet-bottom & 0.23 & 6.75 & 640 \\
\hline \multirow{6}{*}{$>300$} & Gas & 0.05 & 1.46 & 150 \\
\hline & Fuel oil & 0.103 & 3.03 & 300 \\
\hline & Brown coal & 0.14 & 3.95 & 370 \\
\hline & Bituminous coal: & & & \\
\hline & dry-bottom & 0.2 & 5.86 & 540 \\
\hline & wet-bottom & 0.25 & 7.33 & 700 \\
\hline
\end{tabular}

NOx Specific Emission Norms for Boilers to be Installed at TPS since 01.01.2001

\begin{tabular}{|c|c|c|c|c|}
\hline \multirow{2}{*}{$\begin{array}{l}\text { Boiler thermal } \\
\text { output, MWFuel } \\
\text { fired }\end{array}$} & \multirow[t]{2}{*}{$\begin{array}{c}\text { Units of } \\
\text { measurement }\end{array}$} & & & \\
\hline & & $\mathrm{g} / \mathrm{MJ}$ & $\mathrm{kg} / \mathrm{tfe}$ & $\begin{array}{c}\mathrm{mg} / \mathrm{m}^{3} \text { of dry gas } \\
(=1.4)\end{array}$ \\
\hline \multirow{6}{*}{$100-299$} & Gas & 0.043 & 1.26 & 125 \\
\hline & Fuel oil & 0.086 & 2.52 & 250 \\
\hline & Brown coal & 0.11 & 3.2 & 300 \\
\hline & Bituminous coal: & & & \\
\hline & dry-bottom & 0.17 & 4.98 & 470 \\
\hline & wet-bottom & 0.23 & 6.75 & 640 \\
\hline \multirow{6}{*}{$>300$} & Gas & 00.043 & 1.26 & 125 \\
\hline & Fuel oil & 0.086 & 252 & 250 \\
\hline & Brown coal & 0.11 & 2.52 & 250 \\
\hline & Bituminous coal: & & & \\
\hline & dry-bottom & 0.13 & 3.81 & 350 \\
\hline & wet-bottom & 0.21 & 5.97 & 570 \\
\hline
\end{tabular}


SOx Emission Norms for Boilers to be Installed before 01.01.2001

\begin{tabular}{|c|c|c|c|c|c|c|c|}
\hline \multirow{3}{*}{$\begin{array}{l}\text { Boiler thermal } \\
\text { output, MW }\end{array}$} & Unit of & \multicolumn{2}{|c|}{$g / M]$} & \multicolumn{2}{|c|}{$\mathrm{kg} / \mathrm{tfe}$} & \multicolumn{2}{|c|}{$\mathrm{mg} / \mathrm{m}^{3}(=1.4)$} \\
\hline & Fuel & \multicolumn{6}{|c|}{ Normatired S content, $\% \mathrm{~kg} / \mathrm{MJ}$} \\
\hline & & S,0.045 & $S_{8}>0.045$ & $S_{\mathrm{g}} 0.045$ & $S_{2}>0.045$ & $S_{\mathrm{n}} 0.045$ & $S_{n}>0.045$ \\
\hline $100-299$ & $\begin{array}{l}\text { All solid and oil } \\
\text { fuels. }\end{array}$ & 0.875 & 1.5 & 25.7 & 44.0 & 2000 & 3400 \\
\hline 300 & $\begin{array}{l}\text { All solid and oil } \\
\text { fuels }\end{array}$ & 0.875 & 1.5 & 25.7 & 38.0 & 2000 & 3000 \\
\hline
\end{tabular}

SOx Emission Norms for Boilers to be Installed since 01.01.2001

\begin{tabular}{|c|c|c|c|c|c|c|c|}
\hline \multirow{3}{*}{$\begin{array}{l}\text { Boiler thermal } \\
\text { output, MW }\end{array}$} & Unit of & \multicolumn{2}{|c|}{$\mathrm{g} / \mathrm{MI}$} & \multicolumn{2}{|c|}{$\mathrm{kg} / / \mathrm{tfe}$} & \multicolumn{2}{|c|}{$\mathrm{mg} / \mathrm{m}^{\prime}(=1.4)$} \\
\hline & \multirow[t]{2}{*}{ Fuel } & \multicolumn{6}{|c|}{ Normatired S content, \% kg/MJ } \\
\hline & & Sn 0.054 & $\mathrm{Sn}>0.045$ & Sn0.045 & $S_{n}>0.045$ & Sn0.045 & $S_{n}>0.045$ \\
\hline $100-199$ & \multirow{4}{*}{$\begin{array}{l}\text { All solid and oil } \\
\text { fuels }\end{array}$} & 0.5 & 0.6 & 14.77 & 17.6 & 1200 & 1400 \\
\hline $200-249$ & & 0.4 & 0.45 & 11.7 & 13.1 & 950 & 1050 \\
\hline $250-299$ & & 0.3 & 0.3 & 8.8 & 8.8 & 700 & 700 \\
\hline 300 & & \multicolumn{2}{|c|}{0.3} & \multicolumn{2}{|c|}{8.8} & \multicolumn{2}{|c|}{700} \\
\hline
\end{tabular}


Table 3

Particular Matter Specific Emission Norms for Boilers to be Installed before 01.01.2001

\begin{tabular}{|c|c|c|c|c|c|c|c|c|c|c|}
\hline \multirow{3}{*}{$\begin{array}{l}\text { Boiler thermal } \\
\text { output, MW }\end{array}$} & Unit of & \multicolumn{3}{|c|}{$\mathrm{g} / \mathrm{MJ}$} & \multicolumn{3}{|c|}{$\mathrm{kg} / \mathrm{tfe}$} & \multicolumn{3}{|c|}{$\mathrm{mg} / \mathrm{m}^{3}(=1.4)$} \\
\hline & \multirow[b]{2}{*}{ Fuel } & \multicolumn{9}{|c|}{ Normatired ash content, \% kg/MI } \\
\hline & & $\begin{array}{c}\text { below } \\
0.6\end{array}$ & $0.6-2.5$ & $\begin{array}{c}\text { above } \\
25\end{array}$ & $\begin{array}{c}\text { below } \\
0.6\end{array}$ & $0.6-2.5$ & $\begin{array}{c}\text { above } \\
25\end{array}$ & $\begin{array}{c}\text { below } \\
0.6\end{array}$ & $0.6-25$ & $\begin{array}{c}\text { above } \\
25\end{array}$ \\
\hline $100-299$ & All solid fuels & 0.06 & $0.06-0.2$ & 0.2 & 0.176 & $1.76-5.85$ & 5.86 & 150 & $150-500$ & 500 \\
\hline 300 & All solid fuels & 0.04 & 0.040 .16 & 0.16 & 1.175 & $1.175-4.7$ & 4.7 & 100 & $100-400$ & 400 \\
\hline
\end{tabular}

Particulate Matter Specific Emission Norms for Boilers to be Installed since 01.01.2001

\begin{tabular}{|c|c|c|c|c|c|c|c|c|c|c|}
\hline \multirow{3}{*}{$\begin{array}{l}\text { Boiler thermal } \\
\text { output, MW }\end{array}$} & $\begin{array}{c}\text { Units of } \\
\text { measurement }\end{array}$ & \multicolumn{3}{|c|}{$\mathrm{g} / \mathrm{MJ}$} & \multicolumn{3}{|c|}{$\mathrm{kg} / \mathrm{tfe}$} & \multicolumn{3}{|c|}{$\mathrm{mg} / \mathrm{m}^{3}(=1.4)$} \\
\hline & & \multicolumn{9}{|c|}{ Normatired ash content, \% kg/M } \\
\hline & Fuel & $\begin{array}{c}\text { below } \\
0.6\end{array}$ & $0.6-2.5$ & $\begin{array}{c}\text { above } \\
2.5\end{array}$ & $\begin{array}{c}\text { below } \\
0.6\end{array}$ & $0.6-2.5$ & $\begin{array}{c}\text { above } \\
25\end{array}$ & $\begin{array}{c}\text { below } \\
0.6\end{array}$ & $0.6-2.5$ & $\begin{array}{c}\text { above } \\
2.5\end{array}$ \\
\hline $100-299$ & All solid fuels & 0.6 & $0.06-0.1$ & 0.1 & 1.76 & $1.76-2.93$ & 2.93 & 150 & $50-250$ & 250 \\
\hline 300 & All solid fuels & 0.02 & $0.02-0.06$ & 0.06 & 0.586 & $0.586-1.76$ & 1.76 & 50 & $50-150$ & 150 \\
\hline
\end{tabular}


Table 4

Some Data on Steam Turbine Units of Russia

\begin{tabular}{|l|c|c|c|c|c|c|}
\hline \multirow{2}{*}{ Quantity } & \multicolumn{5}{c|}{ Unit rating MW } \\
\cline { 2 - 9 } & 150 & 200 & 300 & 500 & 800 & 1200 \\
\hline Total number of units & 37 & 89 & 101 & 7 & 14 & 1 \\
\hline Including coal-fired units & 27 & 47 & 31 & 7 & $2(5)$ & \\
\hline Number of monoblock & 14 & 57 & 50 & 6 & 14 & 1 \\
\hline Number of two-boilers single-turbine units & 23 & 32 & 51 & 1 & & \\
\hline Number of TKZ boilers & 22 & 58 & 91 & & 12 & 1 \\
\hline Number of ZIO boilers & 38 & 56 & 65 & 8 & 2 & \\
\hline Number of BKZ boilers & & 9 & & & & \\
\hline Number of LMZ turbines & 4 & 89 & 53 & & 14 & 1 \\
\hline Number of KhTZ turbines & 33 & & 26 & 7 & & \\
\hline Number of TMZ turbines & & & 22 & & & \\
\hline Number of EAS alternators & 37 & 31 & 71 & & 14 & 1 \\
\hline Number of ETM alternators & & 58 & 26 & 5 & & \\
\hline Number of SETM alternators & & & 4 & 2 & & \\
\hline Live steam pressure, MPa & 14.0 & 14.0 & 25.5 & 25.5 & 25.5 & 25.5 \\
\hline Live and reheat steam temperature, C & 545 & 545 & 545 & 545 & 545 & 545 \\
\hline Steam Flow, t/h & 500 & $640-670$ & $950-1000$ & 1650 & 2650 & 3950 \\
\hline \multicolumn{1}{|c|}{$\mathrm{kg} / \mathrm{s}$} & 139 & $178-186$ & $264-278$ & 458 & 736 & 1097 \\
\hline Nom.gas flow, thou.ms/h & 500 & 660 & 1060 & 1700 & 2700 & 4000 \\
\hline \multicolumn{1}{|c|}{$\mathrm{kg} / \mathrm{s}$} & 172 & 227 & 364.5 & 585 & 929 & 1376 \\
\hline
\end{tabular}




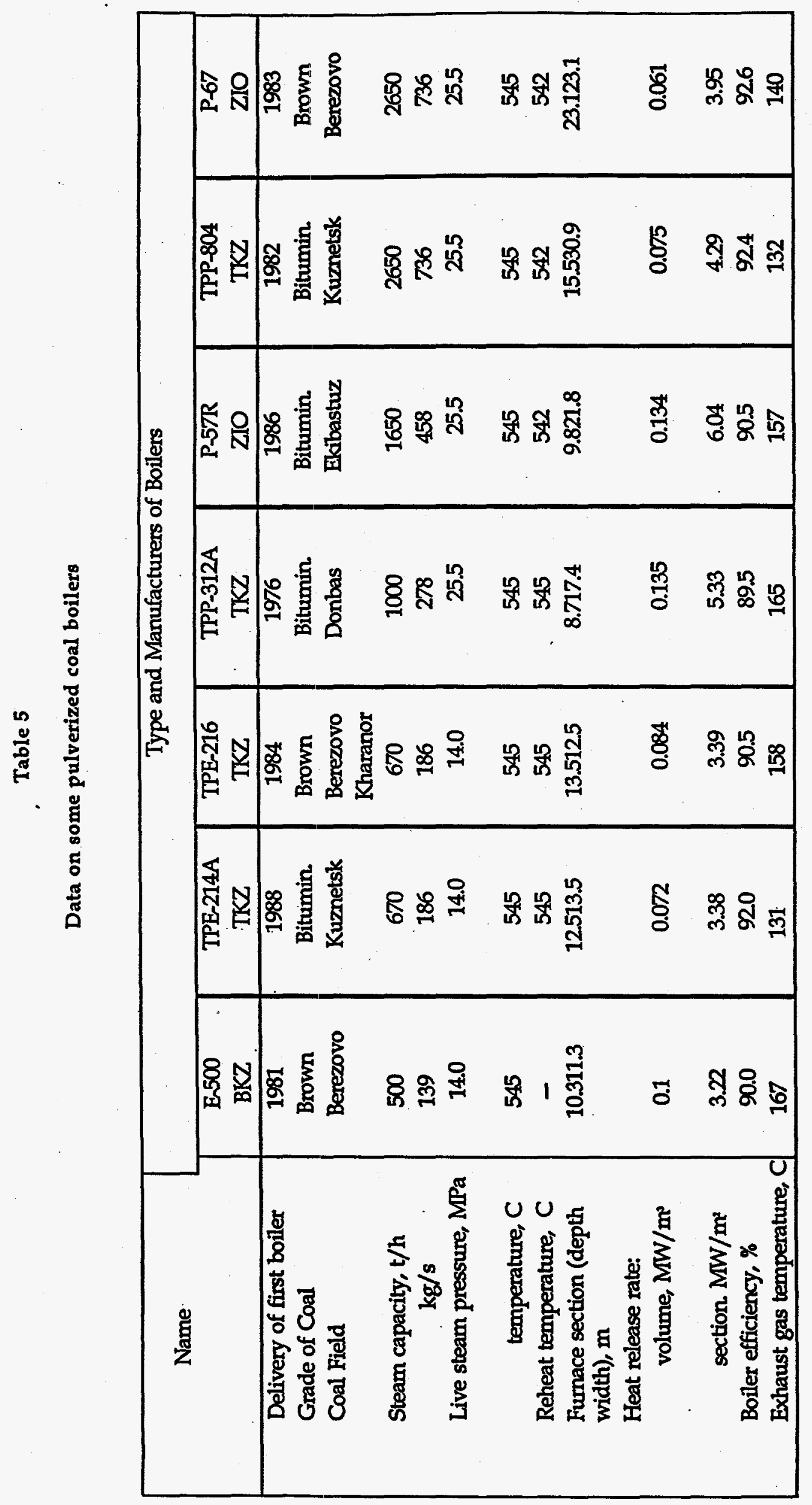




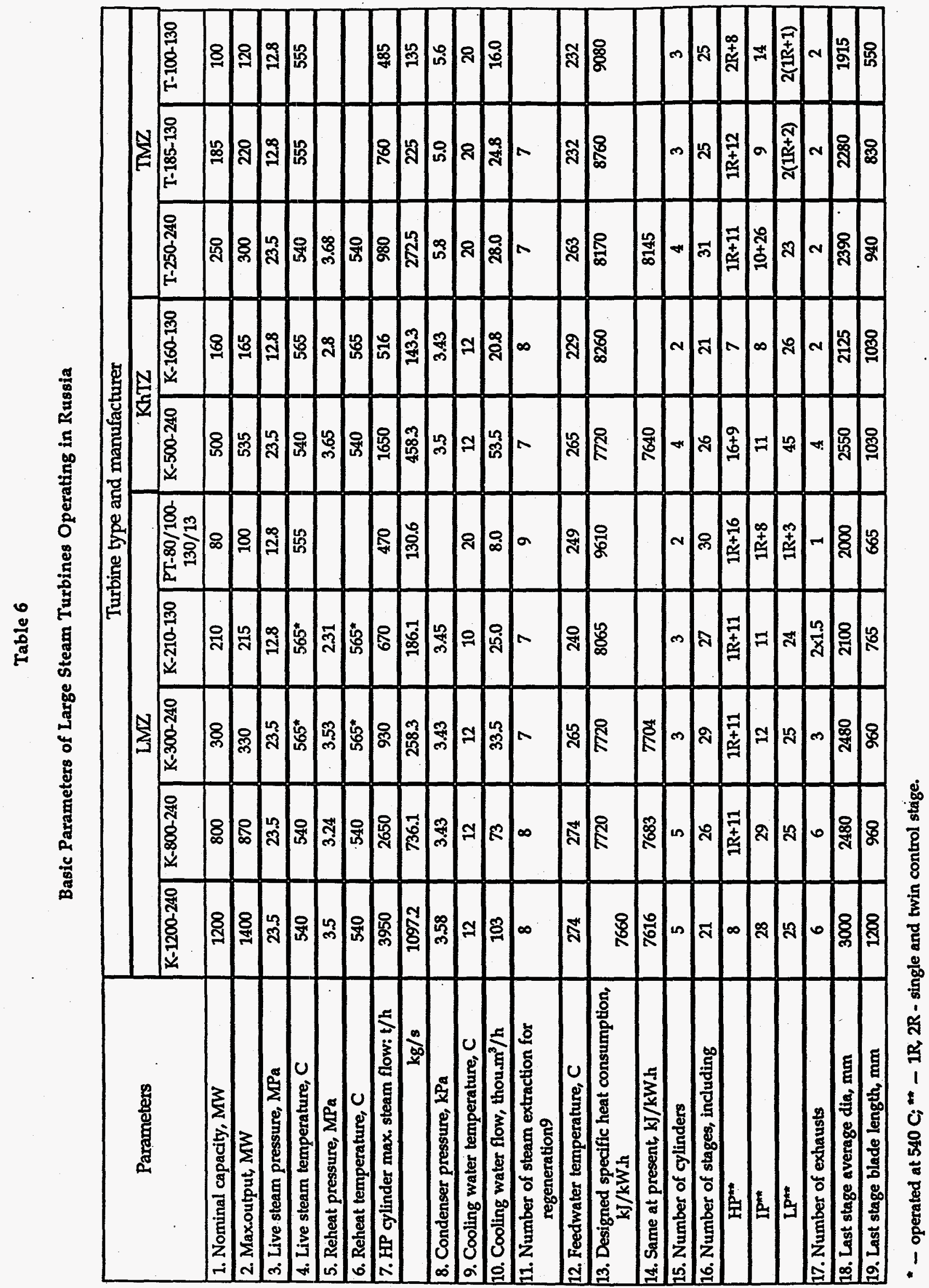


Table 7

Parameters of heavy-duty GT units

\begin{tabular}{|c|c|c|c|c|c|c|c|c|}
\hline \multirow{4}{*}{ Name } & \multicolumn{8}{|c|}{ Type, manufacturer and purpose } \\
\hline & \multicolumn{2}{|c|}{ TMZ } & \multirow{2}{*}{$\frac{\text { NZL }}{\text { GTN-25 }}$} & \multirow{2}{*}{$\frac{\mathrm{KhTZ}}{\mathrm{GTE}-45}$} & \multirow{2}{*}{\begin{tabular}{|l|} 
Mashproject \\
GTG-110 \\
\end{tabular}} & \multicolumn{3}{|c|}{ LMZ } \\
\hline & GTN-16 & GTN-25 & & & & GTE-150 & GTE-150 & GTE-200 \\
\hline & \multicolumn{3}{|c|}{ mechanical drive } & \multicolumn{5}{|c|}{ utility } \\
\hline 1. Output, MW & 16.8 & 25.5 & 30.0 & 54.0 & 110.0 & 131.0 & 161.0 & 190.0 \\
\hline 2. Efficiency, $\%$ & 29.5 & 32.3 & 29.0 & 28.0 & 36.0 & 31.0 & 31.5 & 33.1 \\
\hline 3. Number of shafts & 2 & 2 & 3 & 1 & 1 & 1 & 1 & 1 \\
\hline 4. Turbine inlet gas temperature, $\mathrm{C}$ & 920 & 1060 & 900 & 900 & 1210 & 950 & 1100 & 1250 \\
\hline 5. Turbine outlet gas temperature, $\overline{\mathrm{N}}$ & 430 & 460 & 400 & 475 & 517 & 423 & 530 & 545 \\
\hline 6. Pressure ratio & 11.5 & 13.0 & 12.5 & 7.8 & 14.7 & 13.0 & 13.0 & 15.6 \\
\hline 7. Air flow, kg/s & 89 & 103 & 170 & 271 & 357 & 636 & 630 & 630 \\
\hline 8. Possible heating load, MJ/s & 28.5 & 37.9 & 51.1 & 98.8 & 157 & 220 & 296.5 & 302 \\
\hline 9. Turbine unit weight, $t$ & 60 & 60 & 97 & 180 & 50 & 320 & 320 & 320 \\
\hline
\end{tabular}


Table 8

Parameters of CIS marine and aeroderivative GT units

\begin{tabular}{|c|c|c|c|c|c|c|}
\hline \multirow{4}{*}{ Name } & \multicolumn{6}{|c|}{ Manufacturer, type, year of production } \\
\hline & \multicolumn{2}{|c|}{ Mashproject } & YuTZ & Tushino & "Saturn" & "Trud" \\
\hline & GT-15 & GT-16 & GT-25 & RD29-300 & AL-315TE & NK-37 \\
\hline & 1990 & 1993 & 1994 & 1996 & 1996 & 1994 \\
\hline 1. GT output, MW & 15.8 & 17.0 & 25.7 & 20.0 & 20.0 & 25.0 \\
\hline 2 GT efficiency, \% & 30.0 & 35.5 & 36.8 & 30.0 & 35.5 & 36.4 \\
\hline 3. Pressure ratio & 12.8 & 20.0 & 21.8 & 10.7 & 21.0 & 23.4 \\
\hline 4. Turbine inlet gas temperature, $C$ & & & & 957 & 1252 & 1147 \\
\hline 5. Gas flow, $\mathrm{kg} / \mathrm{s}$ & 98.5 & 71.0 & 85.0 & 98.0 & 620 & 101.0 \\
\hline 6. Turbine outlet gas temperature, C & 365 & 420 & 497 & 457 & 518 & 425 \\
\hline 7. Possible heating load, MW & 23.4 & 226 & 33.3 & 34.4 & 25.9 & 23.1 \\
\hline
\end{tabular}


Table 9

Parameters of Domestic CCPs

\begin{tabular}{|l|c|c|c|}
\hline \multicolumn{1}{|c|}{ Designation } & CCP-450T & CCP-325 & CCP-80 \\
\hline 1. GT type/manufacturer & $\begin{array}{c}\text { V94.2, Siemens- } \\
\text { LMZ }\end{array}$ & $\begin{array}{c}\text { GTG-110, } \\
\text { Mashproject }\end{array}$ & $\begin{array}{c}\text { NK-37, } \\
\text { TRUD }\end{array}$ \\
\hline 2. Number of GTs & 2 & 2 & 2 \\
\hline 3. Heat recovery boiler (HRSG) manufacturer & ZIO & ZIO & BZEM \\
\hline 4. ST manufacturer & LMZ & LMZ & KTZ \\
\hline 5. GT gross output, MW & 143.6 & 110.0 & 24.2 \\
\hline 6. ST gross output, MW162.8 & 115.0 & 19.8 & \\
\hline 7. CCP gross output, MW & 450.0 & 325.0 & 68.2 \\
\hline 8. Auxiliary consumption, MW & 13.5 & 8.1 & 3.4 \\
\hline 9. CCP net output, MW & 436.5 & 316.9 & 64.8 \\
\hline 10. CCP efficiency, \% & 50.0 & 52.5 & 45.5 \\
\hline 11. Gas flow, kg/s & 499.4 & 358.5 & 104.2 \\
\hline 12. Gas turbine outlet temperature, C & 545 & 524 & 429 \\
\hline 13. Exhaust gas temperature, C & 110 & 100 & 130 \\
\hline & HP Circuit & & \\
\hline 14. Steam flow, t/h & 472 & 305 & 71 \\
\hline 15. Steam pressure past HRSG/before ST, MPa & $8.0 / 7.6$ & $7.0 / 6.5$ & $40.8 / 37.0$ \\
\hline 16. Steam temperature past HRSG/before ST, C & $515 / 510$ & $495 / 490$ & $430 / 427$ \\
\hline & LP Circuit & & \\
\hline 17. Steam flow, t/h & 114.0 & 75.0 & 18.5 \\
\hline 18. Steam pressure past HRSG/before ST, MPa & $0.65 / 0.6$ & $0.65 / 0.6$ & $0.765 / 0.6$ \\
\hline 19. Steam temperature past HRBG/before ST, C & $200 / 195$ & $210 / 205$ & $205 / 203$ \\
\hline
\end{tabular}

- 
Table 10

Gas Turbine Blade Alloy characteristics

\begin{tabular}{|c|c|c|c|c|c|c|c|c|c|c|}
\hline \multirow[b]{2}{*}{ Name } & \multicolumn{10}{|c|}{ Deformed alloys } \\
\hline & EI607A & EI893 & EI765 & TsD-1 & TsJ-24 & EP783 & EP800 & EI-929 & EP-220 & EP-957 \\
\hline 1. Ulimate strength, $\mathrm{MPa}$ & 930 & 1050 & 1100 & 1050 & 1150 & 1100 & 1150 & 1150 & 1165 & 1260 \\
\hline 2. Yield point, $\mathrm{MPa}$ & 485 & 560 & 620 & 630 & 660 & 710 & 750 & 730 & 845 & 940 \\
\hline 3. Relative elongation, $\%$ & 39 & 30 & 25 & 25 & 20 & 15 & 10 & 15 & 15 & 8 \\
\hline 4. Impact viscosity, $\mathrm{kJ} / \mathrm{m}^{2}$ & 1350 & 500 & 400 & 400 & 350 & 200 & 200 & 200 & 230 & 110 \\
\hline 5. Stress rupture, MPa: $650 \mathrm{C}$ & 275 & 390 . & 390 & 430 & 480 & & & & & 650 \\
\hline $750 \mathrm{C}$ & & 180 & 180 & 190 & 210 & 275 & 280 & 300 & & 350 \\
\hline $850 \mathrm{C}$ & & & & & & $\cdot$ & 95 & 110 & 130 & 135 \\
\hline \multirow[t]{3}{*}{ 6. Corrosion loss, $\mathrm{mg} / \mathrm{cm}^{2}$} & 9 & 10 & & & & 11 & 320 & 320 & 660 & \\
\hline & \multicolumn{10}{|c|}{ Casting alloys } \\
\hline & EI893L & EP539LMU & TsL-2 & TsL-4 (ZMI-4U & ) $\operatorname{TsL5}(7)$ & ZMI-3 & TsNK-7RS & TsNK-7NK & JSBK-RS & JSBK-NK \\
\hline \multirow[t]{2}{*}{ 1. Ultimate strength, $\mathrm{MPa}$} & 700 & 750 & 740 & 750 & 700 & 800 & 800 & 750 & 950 & 750 \\
\hline & 750 & 850 & 800 & 850 & 850 & 860 & 900 & 1100 & 1000 & 1100 \\
\hline \multirow[t]{2}{*}{ 2. Yield point, $\mathrm{MPa}$} & 440 & 650 & 600 & 600 & 500 & 700 & 700 & 700 & 850 & 700 \\
\hline & 480 & 700 & 700 & 650 & 600 & 750 & 770 & 1050 & 900 & 1100 \\
\hline 3. Relative elongation, \% & $10-25$ & $2-4$ & $2.2-3.6$ & $25-6.0$ & $25-5.0$ & $2.5-5.0$ & $25-7.0$ & $1.5-2.5$ & $1-3$ & $1-20$ \\
\hline 4. Stress rupture, MPa: $650 \mathrm{C}$ & & 580 & & & & 615 & 645 & 665 & & \\
\hline $750 \mathrm{C}$ & 180 & 320 & & & & 335 & 360 & 380 & & \\
\hline $850 \mathrm{C}$ & & 120 & 120 & 115 & 120 & 125 & 145 & 155 & 170 & 190 \\
\hline 5. Corrosion loss, $\mathrm{mg} / \mathrm{cm}^{2}$ & 10 & 8 & 30 & & 6 & 13 & 6 & 6 & 650 & 650 \\
\hline
\end{tabular}


Table 11

Forecast of Electric Energy Generation in Regions of Russia

\begin{tabular}{|c|c|c|c|c|c|c|c|c|c|}
\hline \multirow{2}{*}{ Parameter } & \multirow{2}{*}{$\begin{array}{l}\text { Calendar } \\
\text { year }\end{array}$} & \multicolumn{8}{|c|}{ Main regions } \\
\hline & & Center & $N-W$ & Middle Volga & N.Caucasus & $\begin{array}{l}\text { Urals, } \\
\text { Tumen }\end{array}$ & Siberia & Far East & Total \\
\hline \multirow{2}{*}{ Electricity production, bln $\mathrm{kWh}$} & 1990 & 305.9 & 77.0 & 111.1 & 58.8 & 260.4 & 199.6 & 44.6 & 1057.0 \\
\hline & 2010 & 457.8 & 131.4 & 162.0 & 112.0 & 401.6 & 344.0 & 1021 & 1711.0 \\
\hline \multirow[t]{2}{*}{ Heat consumption, bln GJ } & 1990 & 3.546 & 0.754 & 1.242 & 0.502 & 2.140 & 2.001 & 0.175 & 10.363 \\
\hline & 2010 & 4.112 & 0.892 & 1.708 & 0.586 & 2.483 & 3.538 & 0.837 & 14.156 \\
\hline \multirow[t]{2}{*}{ Installed capacity, GW } & 1990 & 55.3 & 14.5 & 22.5 & 10.8 & 41.2 & 45.2 & 11.1 & 200.7 \\
\hline & 2010 & 84.3 & 24.7 & 34.5 & 25.3 & 71.6 & 73.2 & 26.5 & 340. \\
\hline \multirow[t]{2}{*}{ including TPS, GW } & 1990 & 39.2 & 6.0 & 13.2 & 8.6 & 38.8 & 22.0 & 8.3 & 136.2 \\
\hline & 2010 & 59.3 & 14.9 & 23.9 & 17.7 & 69.8 & 43.3 & 15.7 & 244.6 \\
\hline \multirow[t]{2}{*}{ Max.Load, GW } & 1990 & 47.8 & 11.8 & 16.7 & 11.3 & 38.4 & 31.8 & 7.9 & 165.7 \\
\hline & 2010 & 74.0 & 19.0 & 22.6 & 18.6 & 59.8 & 47.0 & 18.6 & 259.6 \\
\hline \multirow[t]{2}{*}{ Fuel demand, mln tfe } & 1990 & 106.7 & 17.2 & 44.2 & 21.5 & 103.8 & 57.8 & 17.9 & 351.2 \\
\hline & 2010 & 150.0 & 35.0 & 64.5 & 45.4 & 174.0 & 114.0 & 40.3 & 582 \\
\hline Including coal, mln tfe & 1990 & 13.8 & 1.9 & 1.0 & 3.7 & 21.9 & 55.0 & 12.3 & 97.3 \\
\hline 2010 & 27.2 & 6.0 & 9.8 & 10.4 & 67.2 & 99.0 & 27.7 & 219.6 & \\
\hline
\end{tabular}


Table 12

NOx Control Technologies

\begin{tabular}{|c|c|c|c|c|c|c|c|}
\hline 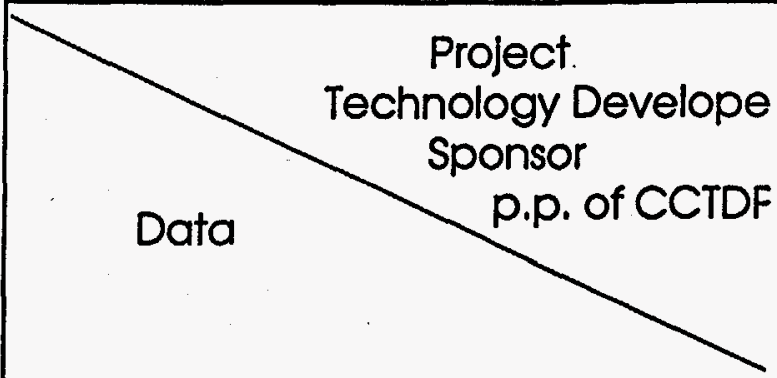 & $\begin{array}{l}\text { The Babcock \& } \\
\text { Wilcox } \\
\text { coal-reburning } \\
\text { system } \\
\text { Babcock \& } \\
\text { Wilcox } \\
\text { Company 7-40 }\end{array}$ & $\begin{array}{c}\text { ABB CE } \\
\text { LNCFS with } \\
\text { AOFA } \\
\\
\text { Southern Co } \\
\text { Services, Inc. } \\
7-48\end{array}$ & $\begin{array}{c}\text { Foster } \\
\text { Wheeler's } \\
\text { LNB with } \\
\text { AOFA } \\
\\
\text { Southern Co } \\
\text { Servisec, Inc. } \\
7-46\end{array}$ & $\mid \begin{array}{c}\text { The Babcock \& } \\
\text { Wilcox Low- } \\
\text { NO Cell } \\
\text { burner system } \\
\text { The Babcock \& } \\
\text { Wilcox } \\
\text { Company } 742\end{array}$ & $\begin{array}{c}\text { EERCs gas- } \\
\text { reburning and } \\
\text { Low-NO, burner } \\
\text { system (GR- } \\
\text { LNB) Energy \& } \\
\text { Envir.Res. Corp. } \\
7.44\end{array}$ & $\begin{array}{c}\text { Fuller's } \\
\text { micronized coal } \\
\text { reburning } \\
\text { technology } \\
\text { Tennessee } \\
\text { Valley } \\
\text { Authority } \\
7.52\end{array}$ & $\begin{array}{l}\text { SCR } \\
\text { Technology } \\
\text { for the } \\
\text { Control of } \\
\text { NOx Emission } \\
\text { Southern Co } \\
\text { Serv. Inc. } \\
7.50\end{array}$ \\
\hline $\begin{array}{l}\text { 1. Power Unit Output, MW } \\
\text { 2. Status (development stage): } \\
\text {. Pilot, demo, commercial. } \\
\text { Date of commercial implementation } \\
\text { 3. Reasonable operating time, ths.hrs/yr } \\
\text { 4. Emissions reduction, \% } \\
\text { 5. Construction period, years } \\
\text { 6. Availability, \% } \\
\text { 7. Kinds of fuel }{ }^{\star \star} \mathrm{A}, \mathrm{Bit}, \mathrm{Lign} \\
\text { 8. Reagents: type } \\
\text { comsumption, g/MJ } \\
\text { 9. Capital investment, doll/kW } \\
\text { 10. Maintenance costs, cents/kW.h } \\
\text { 11. Cost of } 1 \text { t of NO, removed, } \$ \\
\text { 12. Reference Unit Capacity, MW }\end{array}$ & $\begin{array}{c}1995 \\
>6 \\
50 \\
1.0 \\
- \\
\text { Bit, Lign } \\
- \\
- \\
40-65 \\
0.21-0.29 \\
260 \\
200\end{array}$ & $\begin{array}{c}1995 \\
>4 \\
40 \\
0.5 \\
- \\
\text { Bit } \\
- \\
- \\
30-40 \\
0.067-0.17 \\
420-1590 \\
500\end{array}$ & $\begin{array}{c}1995 \\
>4 \\
65 \\
0.2 \\
- \\
\text { Bit } \\
- \\
- \\
30-40 \\
0.067-0.17 \\
420-1590 \\
500\end{array}$ & $\begin{array}{c}300-800 \\
\text { commencial } \\
1995 \\
>4 \\
55 \\
0.2 \\
90,0 \\
\text { Bit } \\
- \\
- \\
5.5-8.0 \\
0.03-0.04 \\
160-450 \\
500\end{array}$ & $\begin{array}{c}50-800 \\
\text { commercial } \\
1995 \\
>4 \\
70 \\
1.0 \\
- \\
\text { Bit } \\
\text { natural gas } \\
<20 \% \\
17-42 \\
0.2-0.7 \\
400-2000 \\
300\end{array}$ & $\begin{array}{l}50-800 \\
\text { demo } \\
1998 \\
>4 \\
50-60 \\
0.5 \\
- \\
\text { Bit } \\
- \\
- \\
32 \\
0.1 \\
- \\
300\end{array}$ & $\begin{array}{c}200-800 \\
\text { pilot } \\
1998 \\
>4 \\
>80 \\
0.92 \\
- \\
\\
\text { ammonia } \\
- \\
80-90 \\
0.4-0.5 \\
700-5000 \\
300\end{array}$ \\
\hline
\end{tabular}

* Clean Coal Technology Demonstration Program; Program Update 1993

** - A (anthracite), Bit (bituminous coals), Lign (Lignites) Service life is about 20 years 
Table 13

$\mathrm{SO}_{2}$ Control Technologies

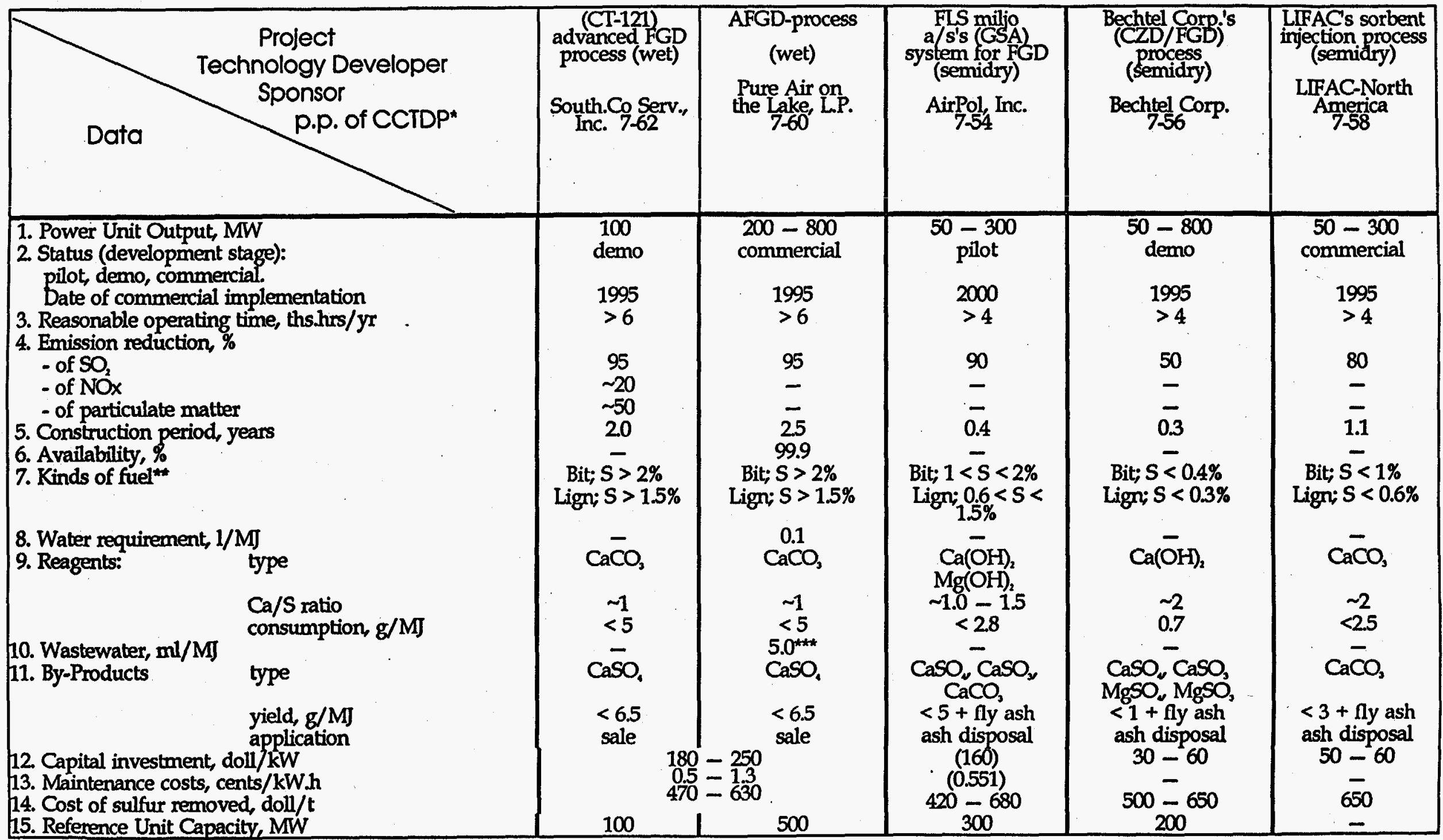

* CCTDP - Clean Coal Technology Demonstration Program; Program Update 1993

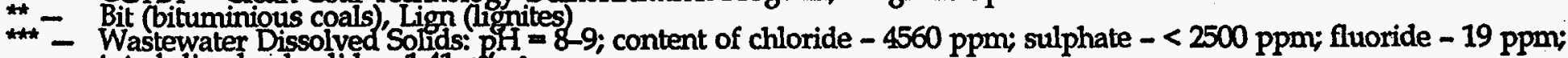

tot al dissolved solids $-1.41 \mathrm{~g} / \mathrm{m}^{3}$

Service life is about 20 years. 
Table 14

Combined SO2/NOx Control Technologies

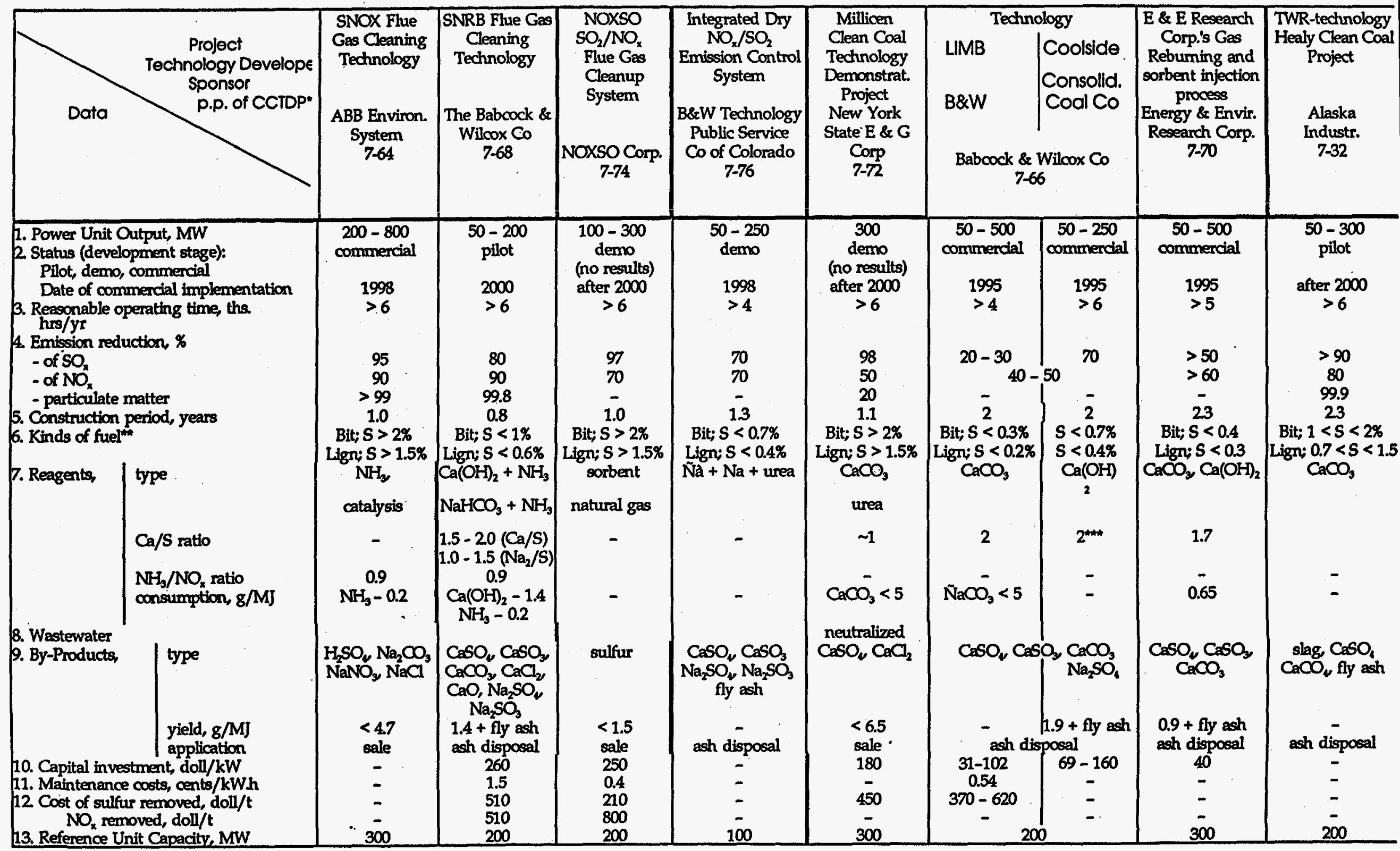

- CCTDP - Clean Coel Technology Demonstration Program Program Update 1993

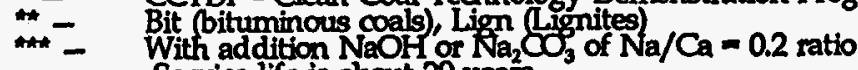
Service life is about 20 years 
Table 15

Basic Characteristics of Coal TPS Emission Reduction Technologies

\begin{tabular}{|c|c|c|c|c|c|c|c|c|c|c|}
\hline \multirow[t]{2}{*}{ Contaminant } & \multirow{2}{*}{\multicolumn{2}{|c|}{ Technology }} & \multirow{2}{*}{$\begin{array}{l}\text { Coal grade and } \\
\text { combustion } \\
\text { technology }\end{array}$} & \multirow{2}{*}{$\begin{array}{c}\text { Maximum } \\
\text { cleaning } \\
\text { efficiency } \\
\%\end{array}$} & \multirow{2}{*}{$\begin{array}{l}\text { Enlarged } \\
\text { specific heat } \\
\text { consumption } \\
\text { Btu/kW.h } \\
(\%)^{* \star 4}\end{array}$} & \multicolumn{2}{|c|}{$\begin{array}{l}\text { Specific cost, } \\
\$ / \mathrm{kW}\end{array}$} & \multirow{2}{*}{$\begin{array}{l}\text { Enlarged } \\
\text { costs for } \\
\text { repair and } \\
\text { service } \\
c / k W . h \\
\end{array}$} & \multicolumn{2}{|c|}{$\begin{array}{l}\text { Enlarged electricity } \\
\text { cost } \\
\text { c/kW.h }\end{array}$} \\
\hline & & & & & & $\begin{array}{l}\text { new } \\
\text { plants }\end{array}$ & $\begin{array}{l}\text { modified } \\
\text { plants }\end{array}$ & & $\begin{array}{l}\text { new } \\
\text { plants }\end{array}$ & $\begin{array}{l}\text { modified } \\
\text { plants }\end{array}$ \\
\hline \multirow[t]{4}{*}{$\begin{array}{l}\text { Sulfur } \\
\text { Dioxide }\end{array}$} & FGD & $\begin{array}{c}\text { Wet Limestone/ } \\
\text { Forced } \\
\text { Oxidation }\end{array}$ & $\begin{array}{l}\text { High Sulfur } \\
\text { Coals }\end{array}$ & $95-98$ & $120(1.34)$ & $130-300$ & $150-250$ & 0.28 & $0.48-0.61$ & $0.53-0.66$ \\
\hline & & $\begin{array}{l}\text { Lime Slurry } \\
\text { Wet/Dry }\end{array}$ & $\begin{array}{l}\text { Low Sulfur } \\
\text { Coals }\end{array}$ & $80-90$ & $60(0.67)$ & $100-150$ & $130-200$ & 0.16 & $0.35-0.40$ & $0.37-0.48$ \\
\hline & & $\begin{array}{l}\text { Simplified } \\
\text { Wet/Dry }\end{array}$ & $\begin{array}{l}\text { Low Sulfur } \\
\text { Coals }\end{array}$ & $60-70$ & $54(0.6)$ & 30 & 70 & 0.15 & 0.30 & 0.35 \\
\hline & & Dry & $\begin{array}{l}\text { Low Sulfur } \\
\text { Coals }\end{array}$ & $30-50$ & $9(0.1)$ & 30 & 40 & 0.10 & 0.10 & 0.10 \\
\hline \multirow[t]{4}{*}{$\begin{array}{l}\text { Nitrogen } \\
\text { Oxides }\end{array}$} & \multicolumn{2}{|c|}{$\begin{array}{c}\text { Low-NO } \mathrm{NO}_{\mathrm{x}} \text { burners + overfire } \\
\text { air supply }\end{array}$} & $\begin{array}{l}\text { reconstruction } \\
\text { of dry-bottom } \\
\text { boilers }\end{array}$ & 40 & $20(0.22)$ & $<10$ & $10-20$ & 0.01 & $<0.03$ & $0.03-0.04$ \\
\hline & \multicolumn{2}{|c|}{$\begin{array}{l}\text { reburning and additional } \\
\text { measures (burners. etc.) }\end{array}$} & $\begin{array}{l}\text { FBC, } P C \text { and } \\
\text { cyclon boilers }\end{array}$ & $50-70$ & $22(0.25)$ & & & 0.10 & 0.04 & 0.05 \\
\hline & \multicolumn{2}{|c|}{$\begin{array}{l}\text { SCR on hot side at high } \\
\text { dust content }\end{array}$} & $\begin{array}{l}\text { rigid standards } \\
\text { for } P C, F B C \text { and }\end{array}$ & $60-80$ & $75(0.84)$ & $70-90$ & $80-100$ & 0.26 & $0.40-0.43$ & $0.41-0.45$ \\
\hline & \multicolumn{2}{|c|}{$\begin{array}{l}\text { SNCR with ammonia or } \\
\text { urea injection }\end{array}$} & $\begin{array}{l}\text { rigid standards } \\
\text { for } P C, C F B, F B C\end{array}$ & $40-80$ & 0 & $5-10$ & $10-20$ & 0.10 & $0.11-0.12$ & $0.12-0.13$ \\
\hline \multirow[t]{3}{*}{ Fly ash } & \multicolumn{2}{|c|}{ ESP } & $\begin{array}{l}\text { High Sulfur } \\
\text { Coals }\end{array}$ & $\begin{array}{l}4.3-8.6^{*} \\
11-22^{* *}\end{array}$ & $\begin{array}{c}5-20 \\
(0.06-0.22)\end{array}$ & 85 & 85 & 0.15 & 0.25 & 0.20 \\
\hline & \multirow[t]{2}{*}{ baghouses } & $\begin{array}{l}\text { reverse air } \\
\text { cleaning }\end{array}$ & $\begin{array}{l}\text { All grades } \\
\text { of coals }\end{array}$ & $4.3^{*} / 11^{* *}$ & $<10(<0.11)$ & 70 & 90 & 0.17 & 0.28 & 0.31 \\
\hline & & $\begin{array}{l}\text { pulse jet } \\
\text { cleaning }\end{array}$ & $\begin{array}{l}\text { All grades } \\
\text { of coals }\end{array}$ & $4.3^{*} / 11^{* *}$ & $20(0.22)$ & 50 & 60 & 0.20 & 0.28 & 0.30 \\
\hline
\end{tabular}

* $\mathrm{mg} / \mathrm{MJ} ;$ at $\mathrm{SR}=1.4$;

at $b_{4}=8980 \mathrm{BTu} / \mathrm{kW} . \mathrm{h}$, which corresponds to $=38 \%$ 
Table 16

Advanced Electric Power Generation Projects

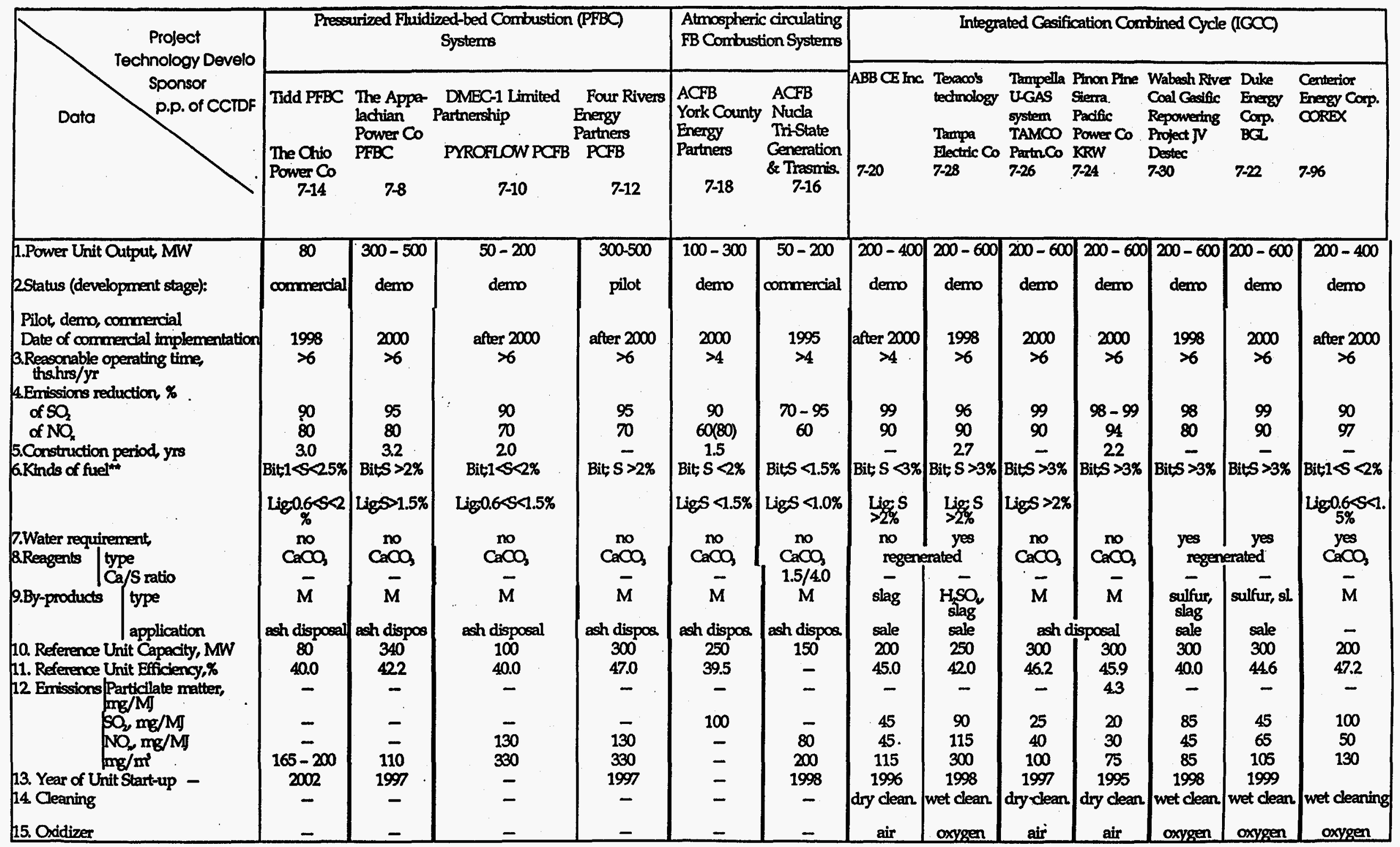

- CCIDP - Clean Coal Tednology Demonstration Program Program Update 1993 Bit(bituminous coals); $\left(\mathrm{CSS}_{2} \mathrm{CaSO}\right)$ and nomutilized $(\mathrm{CaOO})$ sorbent with fly ash
Service life is about 20 years 
Table 17

IGCC Demo Projects developed in USA in accordance with CCTP

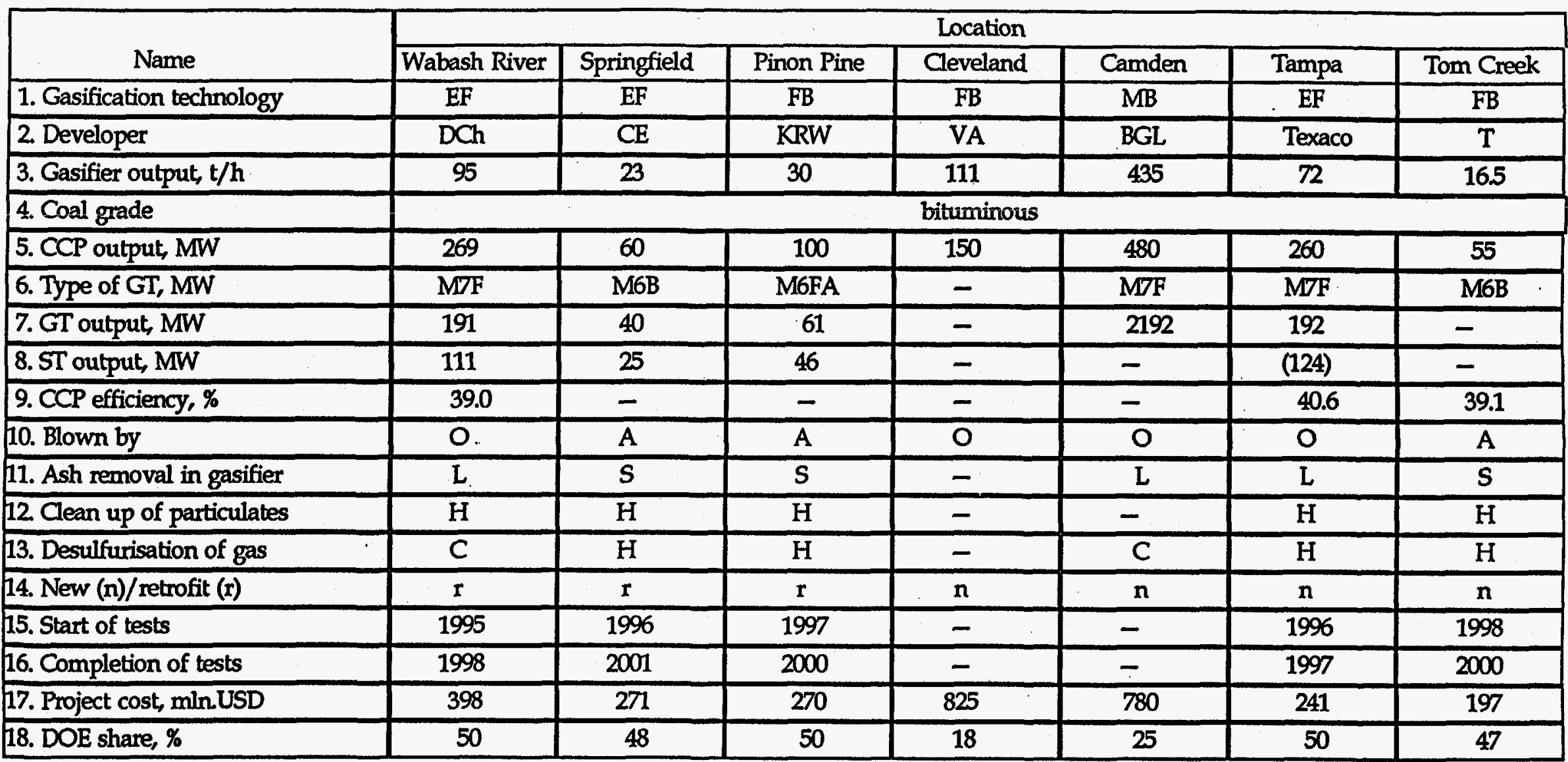

EF - entrained-flow; FB - in fluidized bed; MB - in moving (fixed) bed; DCh - Dow Chemical;

CE - Combustion Engineering VA - Voest Alpine; BGL - British- Gas-Lurgi; KRW - Kellog;

T - Tampella \& Gas Reseanch Institute; O - oxygen; A - air; L - liquid; S -solid; H - hot; C - cold. . 
Table 18

Test Results of Direct Coal Combustion for GT

\begin{tabular}{|c|c|c|c|c|c|}
\hline \multirow[t]{2}{*}{ Name } & \multicolumn{5}{|c|}{ Company } \\
\hline & Solar & \multicolumn{2}{|c|}{ Allison } & \multicolumn{2}{|c|}{ Westinghouse } \\
\hline 1. GT capacity, MW & 4.0 & \multicolumn{2}{|c|}{4.6} & \multicolumn{2}{|c|}{104} \\
\hline 2. Fuel supplied & CWS & \multicolumn{2}{|c|}{ CWS } & dust & CWS \\
\hline 3. Max, particle size, $\mathrm{mm}$ & 75 & \multicolumn{2}{|c|}{15} & 200 & 110 \\
\hline 4. Mean particle size, $\mathrm{mm}$ & 11 & \multicolumn{2}{|c|}{5} & 44 & 40 \\
\hline 5. Ash content (dry), \% & 3.0 & \multicolumn{2}{|c|}{0.8} & \multicolumn{2}{|c|}{6.5} \\
\hline $6.5(\mathrm{dry}), \%$ & $\overline{0.6}$ & \multicolumn{2}{|c|}{0.7} & \multicolumn{2}{|c|}{1.0} \\
\hline 7. Gas outlet temperature, C & 1054 & \multicolumn{2}{|c|}{1127} & 1054 & 1010 \\
\hline 8. Combuster pressure, $\mathrm{MPa}$ & 0.55 & \multicolumn{2}{|c|}{1.07} & 0.59 & 0.60 \\
\hline 9. Air flow, kg/s & 1.60 & 1.86 & 15.0 & \multicolumn{2}{|c|}{3.18} \\
\hline 10. Carbon burnout, $\%$. & 99.9 . & 99.6 & $94-99$ & \multicolumn{2}{|c|}{99} \\
\hline 11. Type of slag removal liquid & dry & \multicolumn{2}{|c|}{ liquid } & & \\
\hline 12. Type of precipitator & & $\mathrm{ial}+\mathrm{t}$ & & \multicolumn{2}{|c|}{ inertial } \\
\hline 13. Ash slag removal, $\%$ & 98 & - & 89 & 90 & 89 \\
\hline 14. Emissions of $\mathrm{NO}_{x^{\prime}} \mathrm{ppm}$ & 29 & 25 & 25 & 90 & 80 \\
\hline 15. Capture of $\mathrm{SO}_{2} \%$ & 55 & 50 & - & 40 & $\overline{22}$ \\
\hline 16. Type of sorbent & \multicolumn{3}{|c|}{ dolomite } & \multicolumn{2}{|c|}{ limestone } \\
\hline 17. $\mathrm{Ca} / \mathrm{S}$ molar ratio & $1.2-1.6$ & 3.7 & - & $\overline{2-4}$ & 3 \\
\hline
\end{tabular}

CWS coal-water-slurry 
Table 19

Quality of Russian Coals Fired at TPS in 1993

\begin{tabular}{|c|c|c|c|c|c|c|c|c|}
\hline \multirow[b]{2}{*}{ Coal Field/Type } & \multirow[b]{2}{*}{ Used at TPS, mln.t } & \multicolumn{6}{|c|}{ Content as per working mass } & \multirow{2}{*}{$\begin{array}{c}\text { Volatiles } \\
\text { V, \% }\end{array}$} \\
\hline & & $W, \%$ & $A, \%$ & $\mathrm{LHV}, \mathrm{MJ} / \mathrm{kg}$ & $\mathrm{C}, \%$ & $\mathrm{~S}, \%$ & $\mathbf{N}, \%$ & \\
\hline Kuznetsk, bit. & 22.3 & 10.7 & 20.4 & 21.8 & $40.5-66.0$ & 0.4 & $1.3-1.8$ & $12-41$ \\
\hline Kansk-Achinsk, br. & 27.5 & 33.1 & 6.8 & 15.4 & $37.4-44.3$ & 0.3 & 0.5 & 48.0 \\
\hline Eastem Donbas, AC & 5.8 & 8.2 & 25.1 & 21.5 & 62.5 & 1.7 & 0.5 & 5.0 \\
\hline Pechora,,bit. (Inta) & 2.2 & 11.6 & 29.1 & 17.0 & 43.9 & 24 & 1.5 & 40.0 \\
\hline Neryungrinsk, bit.(Yakutia) & 4.2 & 8.3 & 15.8 & 24.85 & 64.8 & 0.2 & 0.7 & 20.0 \\
\hline Chelyabinsk, br. (Urals) & 6.4 & 15.2 & 37.2 & 12.6 & 33.8 & 0.8 & 0.9 & 44.0 \\
\hline Near-Moscow, br. & 6.0 & 29.6 & 36.2 & 7.9 & 222 & 2.35 & 0.4 & 48.0 \\
\hline Azeisk,.br. (East) & 8.0 & 23.5 & 17.4 & 16.3 & 43.1 & 0.5 & 0.9 & 48.0 \\
\hline Kharanorsk, br. (East) & 8.2 & 38.6 & 13.6 & 11.8 & 34.3 & 0.3 & 0.5 & 44.0 \\
\hline Bikinsk, br. (Far East) & 5.5 & 38.0 & 28.8 & 7.0 & 22.0 & 0.3 & 0.6 & 53.0 \\
\hline Ekibastuz, subbitum (Kazakhstan) & 25.6 & 6.1 & 39.9 & 16.4 & 41.9 & 0.7 & 0.8 & 25.0 \\
\hline Gusinoozersk, br. (Buryatia) & 25 & 24.7 & 21.3 & 13.1 & 38.3 & 0.4 & 0.6 & 43.0 \\
\hline
\end{tabular}

Bit bituminous; br. brown; AC anthracite culm. 
Table 20

Some Characteristics of Kuznetsk Coals and their Ash

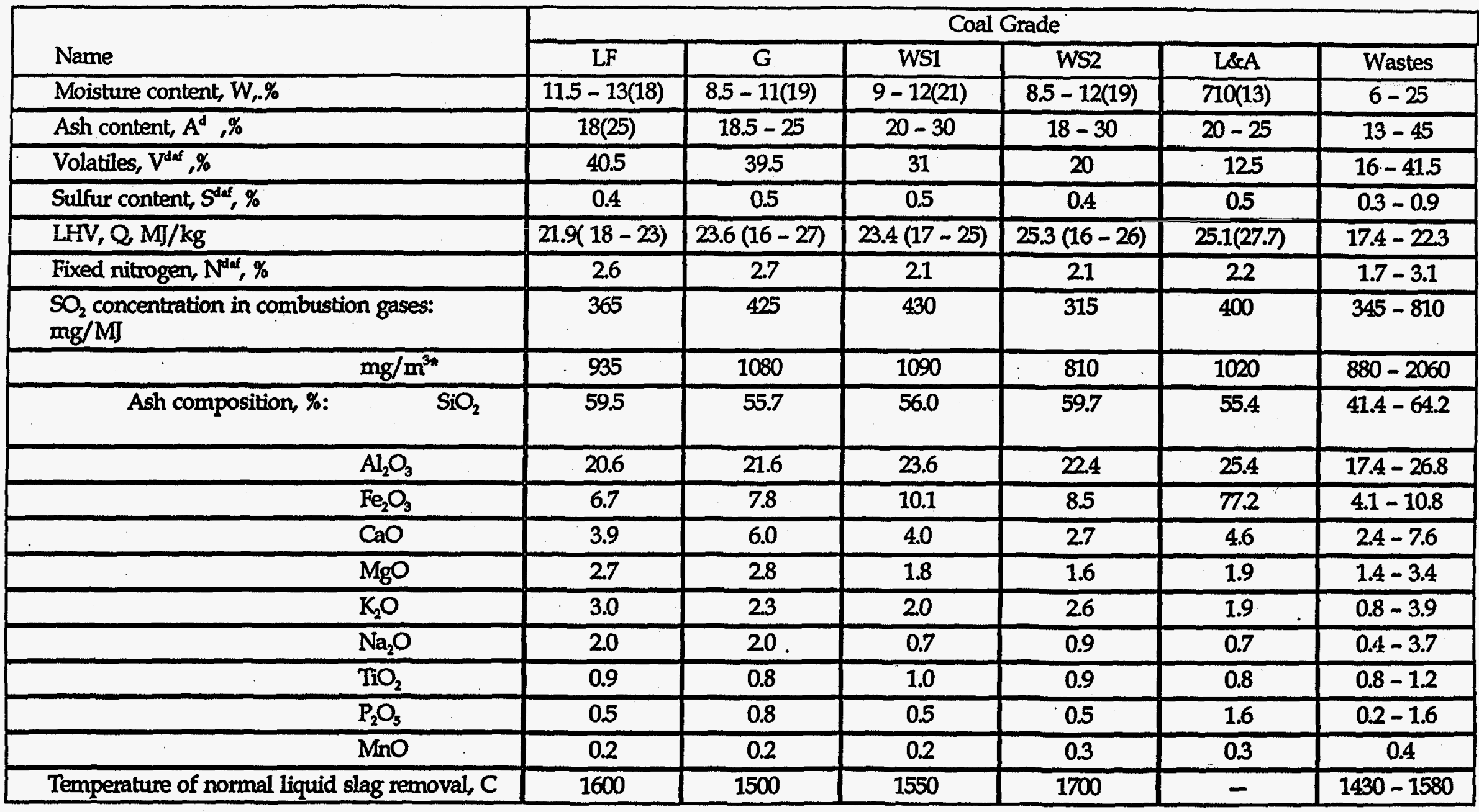

- Here and hereinbelow, the emissions are related to $\mathrm{m}^{3}$ in standard conditions with excess air of 1.4 or $\mathrm{O}_{2}=6 \%$. The bracketed values are limiting for open-cast produced coals. 
Table 21

Some Characteristics of Bituminous Coals and their Ash

\begin{tabular}{|c|c|c|c|c|c|c|c|c|}
\hline \multirow{4}{*}{ Name } & \multicolumn{8}{|c|}{ Field/Coal Grade } \\
\hline & \multicolumn{2}{|c|}{ Pechora } & \multirow{2}{*}{\multicolumn{2}{|c|}{ East Donbass }} & \multirow{3}{*}{$\begin{array}{c}\text { S.-Yakutia. } \\
\text { Neryungri } \\
\text { WS }\end{array}$} & \multirow{2}{*}{\multicolumn{3}{|c|}{ Ekibastuz }} \\
\hline & \multirow{2}{*}{\begin{tabular}{l|} 
Inta \\
LF
\end{tabular}} & \multirow{2}{*}{$\frac{\text { Vorkuta }}{G}$} & & & & & & \\
\hline & & & $\mathrm{L}$ & $\mathrm{AC}$ & & group 1 & group 2 & middle \\
\hline Moisture content, W, \% & 11.5 & 8.0 & 6.9 & 9.0 & 10.0 & 6.0 & 5.0 & 6.0 \\
\hline Ash content, $A^{d}, \%$ & 32.5 & 32.0 & 34.0 & 35.0 & 22.0 & 43.0 & 48.0 & 45.0 \\
\hline Volatiles, $V^{\text {daf, }} \%$ & 40.0 & 33.0 & 12.0 & 4.0 & 20.0 & 25.0 & 25.0 & 25.0 \\
\hline Sulfur content, $S^{\text {daf }}, \%$ & 3.2 & 1.1. & 2.7 & 1.9 & 0.2 & 0.6 & 0.6 & 0.6 \\
\hline $\mathrm{LHV}, \mathrm{Q} \mathrm{MJ} / \mathrm{kg}$ & 16.9 & 20.8 & 20.6 & 19.1 & 225 & 16.1 & 14.6 & 15.5 \\
\hline Fixed nitrogen, $\mathrm{N}^{\mathrm{d} d f}, \%$ & 2.6 & 24 & 0.8 & 0.8 & 0.8 & 1.7 & 1.7 & 1.7 \\
\hline $\begin{array}{l}\mathrm{SO}_{2} \text { concentration in combustion gases, } \\
\mathrm{mg} / \mathrm{MJ}\end{array}$ & 3790 & 1060 & 2620 & 1990 & 180 & & & 770 \\
\hline $\begin{array}{cc}\cdot & \mathrm{mg} / \mathrm{m}^{3}\end{array}$ & 9680 & 2700 & 6700 & 5080 & 460 & & & 1970 \\
\hline Ash composition, \%: & 54.6 & 62.6 & 49.9 & 54.1 & 53.6 & 62.6 & 59.2 & 60.6 \\
\hline $\mathrm{Al}_{2} \mathrm{O}_{3}$ & 18.6 & 19.4 & 223 & 23.9 & 27.5 & 28.2 & 29.6 & 28.6 \\
\hline $\mathrm{Fe}_{2} \mathrm{O}_{3}$ & 14.1 & 8.6 & 17.5 & 11.1 & 8.0 & 5.0 & 6.0 & 5.4 \\
\hline $\mathrm{CaO}$ & 6.9 & 3.0 & 4.0 & 29 & 4.9 & 1.0 & 1.6 & \\
\hline $\mathrm{MgO}$ & 23 & 2.3 & 1.6 & 1.7 & 24 & 0.7 & 0.6 & \\
\hline $\mathrm{K}_{2} \mathrm{O}$ & 1.3 & 2.1) & 28 & 3.5 & 0.7 & 0.6 & 0.5 & \\
\hline $\mathrm{Na}_{2} \mathrm{O}$ & 1.4 & 1.0 & 1.2 & 1.5 & 0.7 & 0.2 & 0.2 & 0.2 \\
\hline $\mathrm{TiO}_{2}$ & 0.8 & 1.9 & 0.7 & 1.3 & 1.2 & 1.1 & 1.3 & \\
\hline $\mathrm{P}_{2} \mathrm{O}_{5}$ & & & & & 0.8 & 0.6 & 0.7 & \\
\hline $\mathrm{MnO}$ & & & & & 0.2 & 0.1 & 0.2 & \\
\hline Temperature of normal liquid slag removal, $\mathrm{C}$ & 1450 & 1550 & 1400 & 1550 & 1600 & 1650 & 1580 & 1600 \\
\hline
\end{tabular}




\section{Table 22}

Brown Coal Ash Chemical Composition and Fusibility

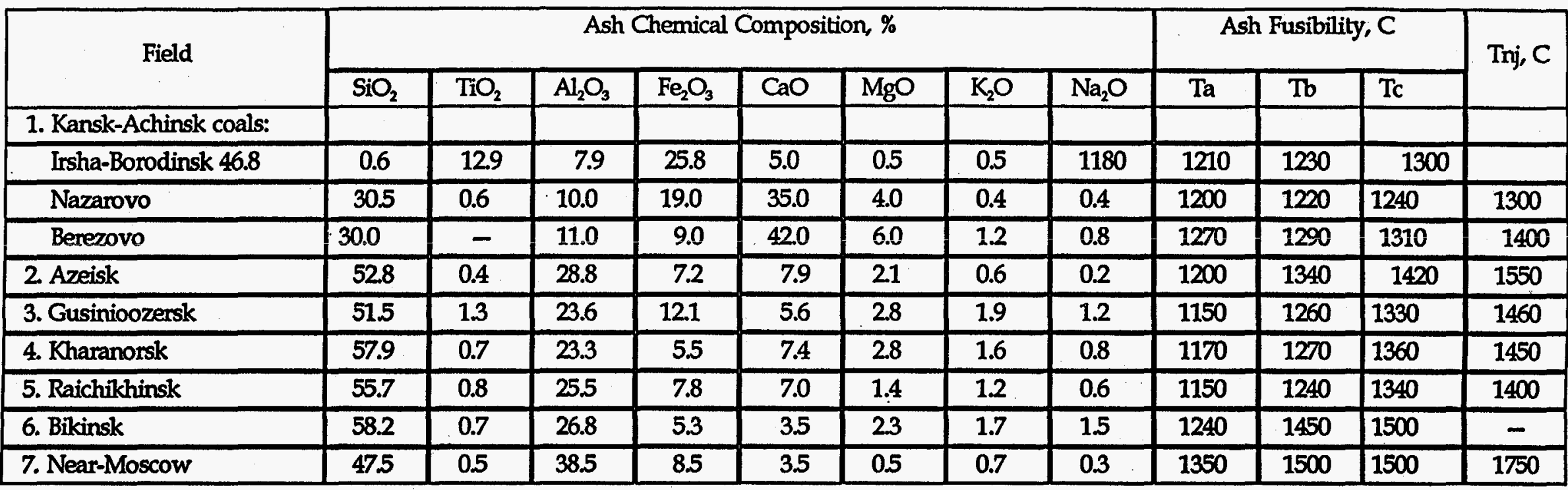

$\mathrm{Ta}, \mathrm{Tb}, \mathrm{Tc}, \mathrm{C}$ typical temperatures of ash softening;

Trij, C temperature of beginning of normal liquid slag removal. 
Base-Case Options of Russian Advanced Coal TPS

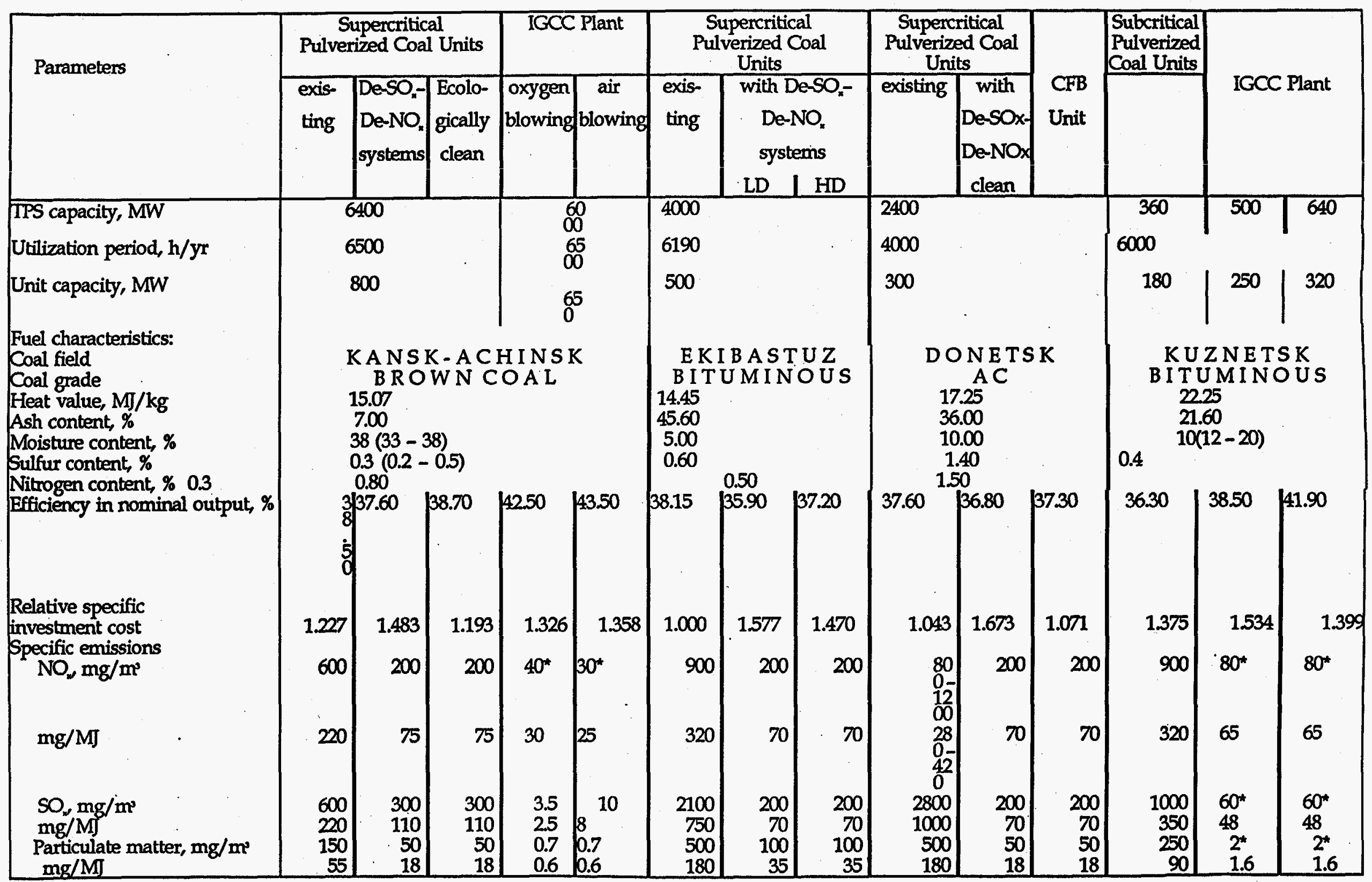

- For IGCC Plants the emissions are related to $\mathrm{m}^{\mathrm{s}}$ in standard conditions with excess air of 3.0 or $\mathrm{O}_{2}=15 \%$ 
Table 24

Technical Characteristics of modular type FRO-12000 fabric filter

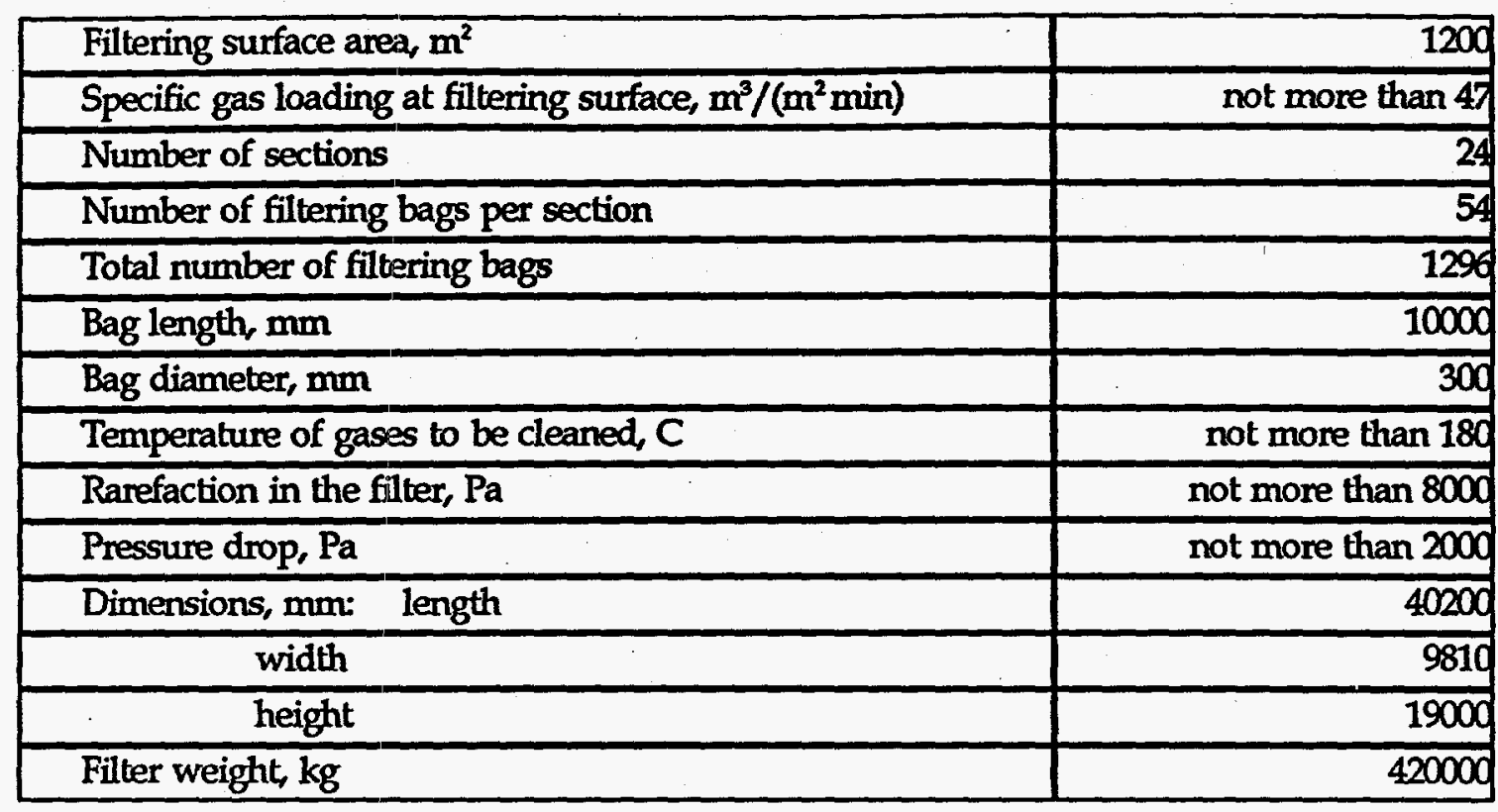


Table 25

Characteristics of catalysts for different $\mathrm{De}-\mathrm{NO}_{x}$ locations

\begin{tabular}{|l|c|c|}
\hline \multirow{2}{*}{ Name } & \multicolumn{2}{|c|}{ De-NO $_{\mathbf{x}}$ location } \\
\cline { 2 - 3 } & before air heater & past De-SO \\
\hline Flue gases dust content, $\mathrm{g} / \mathrm{m}^{3}$ & $70-100$ & not more than 0.15 \\
\hline $\mathrm{SO}_{2}$ concentration, $\mathrm{mg} / \mathrm{m}^{3}$ & $2000-2200$ & $200-300$ \\
\hline Temperature, $\overline{\mathrm{N}}$ & $300-320$ & $320-350$ \\
\hline Catalyst & & \\
\hline channel size, $\mathrm{mm}$ & $6.1-6.3$ & $3.4-3.6$ \\
\hline surface, $\mathrm{m}^{2} / \mathrm{m}^{3}$ & $430-470$ & 750 \\
\hline relative activity & 1.0 & $1.0-1.2$ \\
\hline relative volume & 1.0 & $0.4-0.5$ \\
\hline service life, thou.h & $12-15$ & 24 \\
\hline Relative pressure drop & 1.0 & $1.0-25$ \\
\hline
\end{tabular}


Table 26

Some Data of Limestone DeSO Plant

\begin{tabular}{|c|c|}
\hline Cleaned gas flow, $\mathrm{m}^{3} / \mathrm{h}$ & 2110 \\
\hline Gas temperature: before DeSO $_{x}$ plant, C & 100 \\
\hline past absorber, $\mathrm{C}$ & 50 \\
\hline past DeSO $x_{x}$ plant, $C$ & 55 \\
\hline $\mathrm{SO}_{2}$ Concentration: before $\mathrm{DeSO}_{\mathrm{x}}$ plant, $\mathrm{mg} / \mathrm{m}^{3}$ & 2100 \\
\hline past DeSO $\times$ plant, $\mathrm{mg} / \mathrm{m}^{3}$ & 300 \\
\hline $\mathrm{SO}_{2}$ discharge after cleaning, $\mathrm{g} / \mathrm{s}$ & 175 \\
\hline Pressure drop, $\mathrm{kPa}$ & $\overline{3.5}$ \\
\hline Limestone consumption (95\% of calcite), $\mathrm{kg} / \mathrm{h}$ & 6860 \\
\hline Amount of gypsum produced, $\mathrm{kg} / \mathrm{h}$ & 10860 \\
\hline Service water consumption, $\mathrm{m}^{3} / \mathrm{h}$ & 60 \\
\hline Gas dust content: before DeSO $\times$ plant, $\mathrm{mg} / \mathrm{m}^{3}$ & 150 \\
\hline past DeSO, plant, $\mathrm{mg} / \mathrm{m}^{3}$ & 100 \\
\hline
\end{tabular}


Table 27

Performance of $500 \mathrm{MW}$ Unit with differ De-NO $\mathrm{N}_{\mathrm{x}}$ Plant Location

\begin{tabular}{|c|c|c|c|}
\hline \multirow{3}{*}{ Parameter } & \multicolumn{3}{|c|}{500 MW Unit } \\
\hline & \multirow[b]{2}{*}{ Ekibastuz TPS-2 } & \multicolumn{2}{|c|}{ Ecologicaly clean TPS } \\
\hline & & $\operatorname{DeNO}_{x}$ past $\mathrm{DeSO}_{x}$ & in-build DeNO \\
\hline Additional capacity*, MW & 0 & 4.8 & 1.1 \\
\hline \multicolumn{4}{|l|}{ Heating surface, thou.m² } \\
\hline air heater & 163 & 252 & 252 \\
\hline economizer & 124 & 124 & 17.3 \\
\hline heat exchangers: air-water & - & 3.42 & 6.12 \\
\hline in-build air-water & - & 23.10 & 7.50 \\
\hline gas-gas & - & 230.00 & - \\
\hline Design power of draft machines. MW & 10.22 & 20.48 & 13.70 \\
\hline ESP power, MW & 2.05 & 3.80 & 3.80 \\
\hline Power consumed for DeSO , plant, MW & - & 5.53 & 5.68 \\
\hline Increased auxiliary power, MW & - & 17.54 & 13.15 \\
\hline Total fuel consumption, $t / h$ & 327.3 & 339.0 & 327.2 \\
\hline Boiler efficiency, \% & 91.09 & 94.37 & 94.07 \\
\hline Exhaust gas temperature, C & 159 & 99 & 100 \\
\hline $\begin{array}{l}\text { Annual specific fuel consumption, } \\
\mathrm{g} / \mathrm{kW} . \mathrm{h}\end{array}$ & 3224 & 3427 & 330.3 \\
\hline Annual efficiency, $\%$ & 38.15 & 35.89 & 37.20 \\
\hline Relative specific investment cost & 1.0 & 1.58 & 1.50 \\
\hline
\end{tabular}

- Power, produced by steam which was not used for feedwater preheating 


\begin{tabular}{|c|c|}
\hline \multicolumn{2}{|l|}{ FURNACE } \\
\hline Number per boilers & 2 \\
\hline Plan dimensions, $\mathrm{mm}$ & 108008600 \\
\hline $\begin{array}{l}\text { Outer diameter and wall thickness of waterwall tubes, } \\
\mathrm{mm}\end{array}$ & 326 \\
\hline Heat absorption surface of furnace waterwalls, $\mathbf{m}^{2}$ & 1144 \\
\hline \multicolumn{2}{|l|}{$\begin{array}{r}\text { CYCLONES } \\
\end{array}$} \\
\hline Number per boiler & 4 \\
\hline Inner diameter, $\mathbf{m m}$ & 10000 \\
\hline Inlet port size, mm & 25005715 \\
\hline Letdown inner diameter, mm & 1500 \\
\hline Total height, mm & 25000 \\
\hline EXTERNAL HEAT EX & $\cdot$ \\
\hline Number per boiler & 4 \\
\hline Number of main superheater sections & 2 \\
\hline Number of reheater sections & 1 \\
\hline Outer diameter and wall thickness of tube, $\mathrm{mm}$ & 386 \\
\hline Heat transfer surface, $\mathrm{m}^{2}$ & $1250+480$ \\
\hline \multicolumn{2}{|l|}{ Exchanger dimensions, mm: length14200 } \\
\hline width & 6000 \\
\hline height & 6000 \\
\hline \multicolumn{2}{|c|}{ CONVECTIVE SECTION } \\
\hline Superheater: number of banks & 1 \\
\hline tube dia, men & 3206 \\
\hline heat transfer surface, $\mathrm{m}^{2}$ & 2750 \\
\hline Reheater: number of banks & 2 \\
\hline tube dia, $\mathbf{m m}$ & 424 \\
\hline heat transfer surface, $\mathrm{m}^{2}$ & 6230 \\
\hline Economiser: number of banks & 2 \\
\hline tube dia., $\mathrm{mm}$ & 383 \\
\hline heat transfer surface, $\mathrm{m}^{2}$ & 8200 \\
\hline Air heater. number of banks & 3 \\
\hline number of passes & 4 \\
\hline tube dia, $\mathrm{mm}$ & 401.5 \\
\hline heat transfer surface, $\mathrm{m}^{2}$ & 67500 \\
\hline Boiler dimensions, $\mathrm{m}$ : width & 39.0 \\
\hline depth & 43.5 \\
\hline height & 52.5 \\
\hline
\end{tabular}


Table 29

\section{Some Data of CFB 300 MW AC-fired Boilers}

\begin{tabular}{|c|c|}
\hline Boiler capacity, $t / h$ & 1000 \\
\hline Flow of reheated steam, $t / h$ & 800 \\
\hline Temperature of superheated steam, C & 545 \\
\hline Temperature of reheated steam, C & 545 \\
\hline Pressure of live steam, $\mathrm{MPa}$ & 25.0 \\
\hline Pressure of reheated steam, $\mathrm{MPa}$ & 3.8 \\
\hline Feedwater temperature, $\mathrm{C}$ & 270 \\
\hline Boiler efficiency, $\%$ & 86.4 \\
\hline Heat losses, \%: exhaust gases & 5.5 \\
\hline unburned gases $(\mathrm{CO}, \mathrm{CH}$, etc.) & 0 \\
\hline carbon loss & 6.0 \\
\hline external & 0.2 \\
\hline slag & $\overline{0.4}$ \\
\hline limestone decomposition & 1.5 \\
\hline Total fuel consumption, $t / h$ & 176.6 \\
\hline Limestone consumption, $\mathrm{t} / \mathrm{h}$ & 16.8 \\
\hline Exhaust gas temperature, $\mathrm{C}$ & $140(100)$ \\
\hline Furnace thermal characteristics: & \\
\hline outlet temperature, $\mathrm{C}$ & 900 \\
\hline mean gas velocity, $\mathrm{m} / \mathrm{s}$ & 6.4 \\
\hline volume heat release rate, $\mathrm{kW} / \mathrm{m}^{3}$ & 169.3 \\
\hline Furnace ash balance: & \\
\hline flue gas fly ash concentration at furnace outlet, $\mathrm{kg} / \mathrm{m}^{3}$ & 10.4 \\
\hline fly ash circulation ratio & 180 \\
\hline ash fed to furnace, $t / h$ & 5300 \\
\hline Air distribution: & \\
\hline furnace air excess & 1.02 \\
\hline same,past air heater & 1.28 \\
\hline share of primary air of total air flow, \% & 50 \\
\hline share of secondary air, $\%$ & 50 \\
\hline share of recirculation air past air heater, $\%$ & 9.5 \\
\hline Temperature, $\mathrm{N}:$ & \\
\hline economizer inlet water & 270 \\
\hline furnace chamber wall outlet steam & 394 \\
\hline convective superheater outlet steam & 402 \\
\hline external heat exchanger superheater outlet steam & 545 \\
\hline convective reheater inlet steam & 287 \\
\hline same, outlet steam & 446 \\
\hline external heat exchanger reheater outlet steam & 545 \\
\hline cold air & 30 \\
\hline air heater inlet & 50 \\
\hline air heater outlet & 300 \\
\hline Convective section gas velocity, $\mathrm{m} / \mathrm{s}$ : & \\
\hline superheater & 10.0 \\
\hline reheater & 10.0 \\
\hline economizer & 6.5 \\
\hline air heater & 13.3 \\
\hline Air heater air velocity, $\mathrm{m} / \mathrm{s}$ & 6.9 \\
\hline
\end{tabular}


Table 30

IGCC Plant Performance

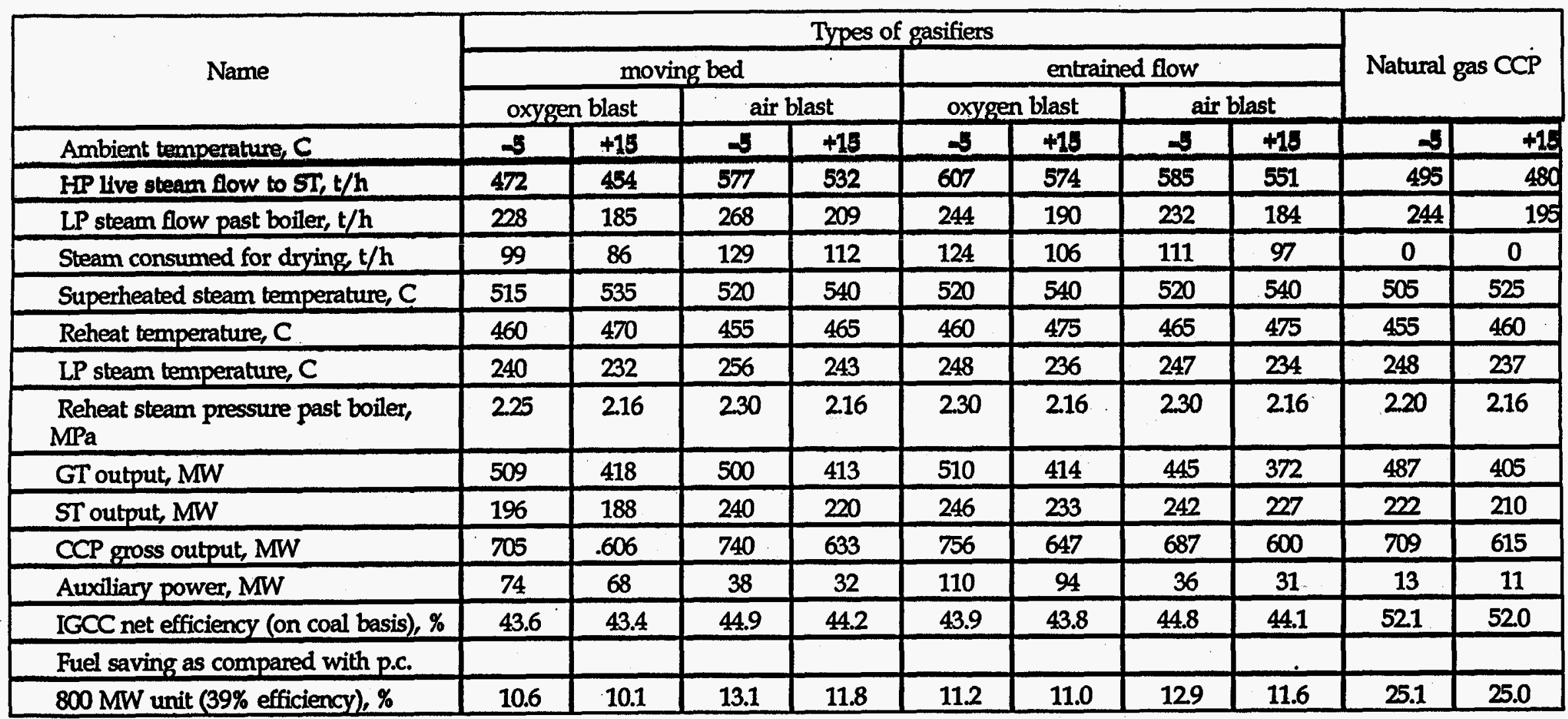


Table 31

Coal characteristics adopted in CCP design

\begin{tabular}{|l|c|c|c|c|}
\hline \multirow{2}{*}{ Parameter } & \multicolumn{4}{|c|}{ Coal grade } \\
\cline { 2 - 5 } & \multicolumn{2}{|c|}{ Berezovo } & \multicolumn{2}{c|}{ Kuznetsk WS2 } \\
\cline { 2 - 5 } & raw & dried & raw & dried \\
\hline Heat value, Q MJ/kg & 15.66 & 21.97 & 20.51 & \\
\hline Ash content, \% & 4.70 & 6.60 & 24.00 & \\
\hline Moisture, \% & 33.00 & 6.00 & 11.50 & \\
\hline Sulfur content, \% & 0.20 & 0.28 & 0.40 & \\
\hline $\begin{array}{l}\text { Elementary composition on fired basis, \%: } \\
\text { C }\end{array}$ & 44.63 & 62.62 & 56.80 & 63.20 \\
\hline H & 3.06 & 4.29 & 3.01 & 3.35 \\
\hline $\mathrm{N}$ & 0.61 & 0.86 & 1.38 & 1.53 \\
\hline $\mathrm{O}$ & 13.8 & 19.35 & 3.01 & 3.35 \\
\hline Volatiles per combustibles, \% & 48.00 & & 20.00 & \\
\hline
\end{tabular}


Table 32

Composition and properties of coal-derived gas

\begin{tabular}{|c|c|c|c|c|}
\hline \multirow{4}{*}{ Parameters } & \multicolumn{4}{|c|}{ Gasification technology and type of blast } \\
\hline & \multirow{2}{*}{\multicolumn{2}{|c|}{$\begin{array}{c}\text { moving-bed } \\
\text { air }\end{array}$}} & \multirow{2}{*}{\multicolumn{2}{|c|}{$\begin{array}{c}\text { entrained-flow } \\
\text { oxygen (95\%) }\end{array}$}} \\
\hline & & & & \\
\hline & raw & cleaned & raw, & cleaned \\
\hline \multicolumn{5}{|l|}{ Gas composition, \% } \\
\hline including: $\quad C O$ & 19.52 & 19.53 & 54.60 & 54.70 \\
\hline $\mathrm{CO}_{2}$ & 5.92 & 5.93 & 9.70 & 9.72 \\
\hline$\overline{\mathrm{H}_{2}}$ & 10.17 & 10.18 & 20.40 & 20.44 \\
\hline $\mathrm{H}_{2} \mathrm{~S}$ & 0.06 & & 0.175 & \\
\hline $\mathrm{CH}_{4}$ & 1.39 & 1.39 & & \\
\hline $\mathrm{H}_{2} \mathrm{O}$ & 14.96 & 14.97 & 14.10 & 14.10 \\
\hline $\mathbf{N}_{2}$ & 47.98 & 48.00 & 1.00 & 1.00 \\
\hline Density, $\mathrm{kg} / \mathrm{m}^{3}$ & 1.120 & 1.001 & 1.005 & \\
\hline Low heat value, $\mathrm{MJ} / \mathrm{m}^{3}$ & 4.07 & 4.06 & 9.09 & 9.07 \\
\hline \multicolumn{5}{|l|}{ Consumption per $1 \mathrm{~kg}$ of dried coal, $\mathrm{kg}$} \\
\hline oxydant & & 2.69 & 0.74 & \\
\hline steam & & 0.40 & & \\
\hline Combustible gas yield, $\mathrm{kg} / \mathrm{kg}$ & & 4.454 & 1.590 & \\
\hline Raw gas temperature at reaction zone outlet, $C$ & 1280 & & 1530 & \\
\hline
\end{tabular}

With entrained-flow oxygen-blown gasification of Kuznetsk coal featuring lower ash melt temperature, the gasifier outlet temperature is adopted at $1300 \mathrm{C}$. The raw syngas contains $65 \mathrm{CO}, 27 \% \mathrm{CO}_{2}, 29.7 \% \mathrm{H}_{2} ;$ its $\mathrm{LHV}=11.43$ $\mathrm{MJ} / \mathrm{m}^{3}$, density $0.925 \mathrm{~kg} / \mathrm{m}^{3}$. 
Table 33

Characteristics of fluidized bed gasification system

\begin{tabular}{|l|c|}
\hline & $2.0-2.1$ \\
\hline Reaction chamber pressure, $\mathrm{MPa}$ & 8.7 \\
\hline Fluidized bed area, $\mathrm{m}^{2}$ & 3.0 \\
\hline Fluidized bed height, $\mathrm{m}$ & 4.07 \\
\hline Combustible gas $\mathrm{LHV}, \mathrm{MJ} / \mathrm{kg}$ & $60(16.7)$ \\
\hline Flows for one gasifier, $\mathrm{t} / \mathrm{h}(\mathrm{kg} / \mathrm{s}):$ & $230(63.9)$ \\
\hline coal & $8(2.2)$ \\
\hline steam and air & \\
\hline ash from bed & 3.15 \\
\hline Consumption of oxydlizers per $\mathrm{kg}$ of coal, $\mathrm{kg}:$ & 0.67 \\
\hline air & 4.3 \\
\hline steam & \\
\hline Gas yield, $\mathrm{kg} / \mathrm{kg}$ of coal & 1100 \\
\hline Temperature, $\mathrm{C}$ & 450 \\
\hline in reaction volume & 950 \\
\hline steam-air & 210 \\
\hline gas past reactor & 160 \\
\hline gas before cleaning & 310 \\
\hline gas past cleaning & 23.65 \\
\hline gas before expansion turbine & $10-12$ \\
\hline Coal characteristics: $\mathrm{LHV}, \mathrm{MJ} / \mathrm{kg}$ & $13-21.5$ \\
\hline Moisture, $\%$ & $0.35-0.40$ \\
\hline Ash content, $\%$ & \\
\hline Sulfur content, $\%$ & \\
\hline
\end{tabular}




\section{FIGURES}

F-1 
F-2 


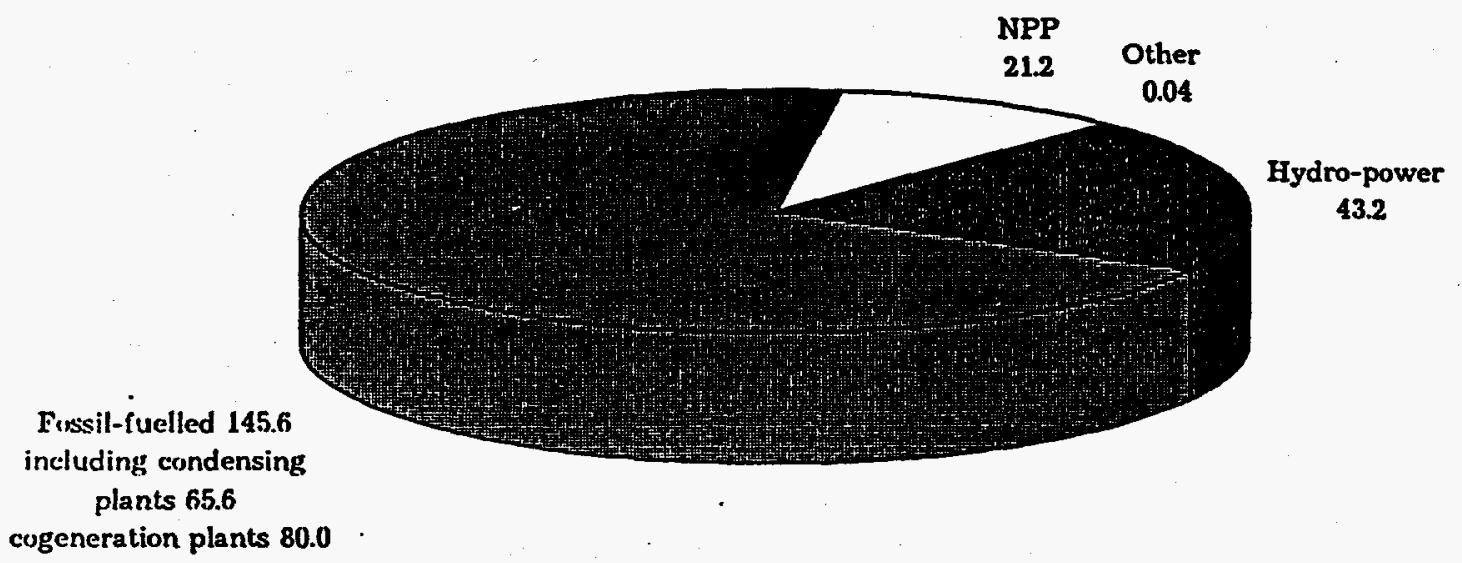

Fig.1. Russian electric power generation mix, GW

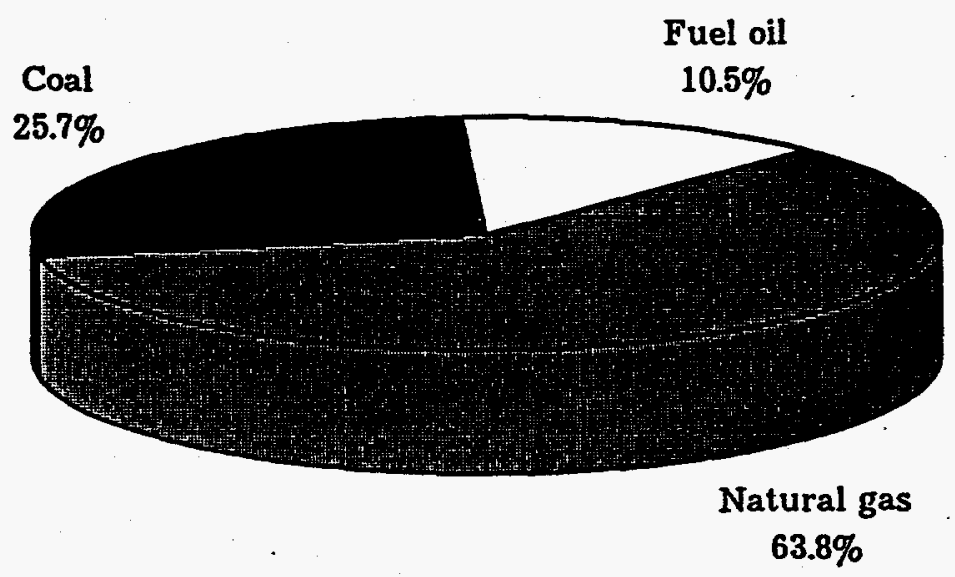

Fig. 2. Russian fuel mix for fossil power plants 


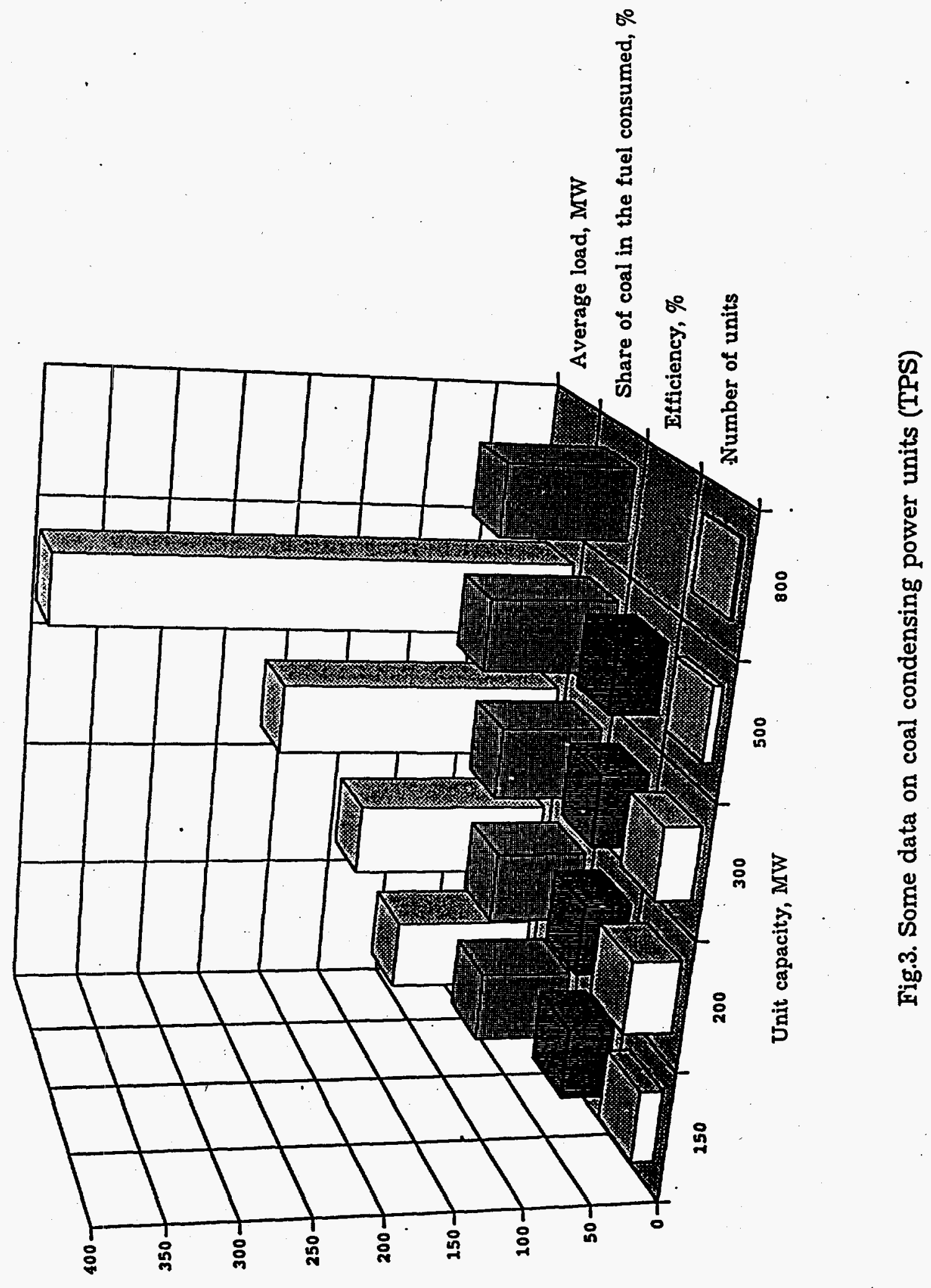




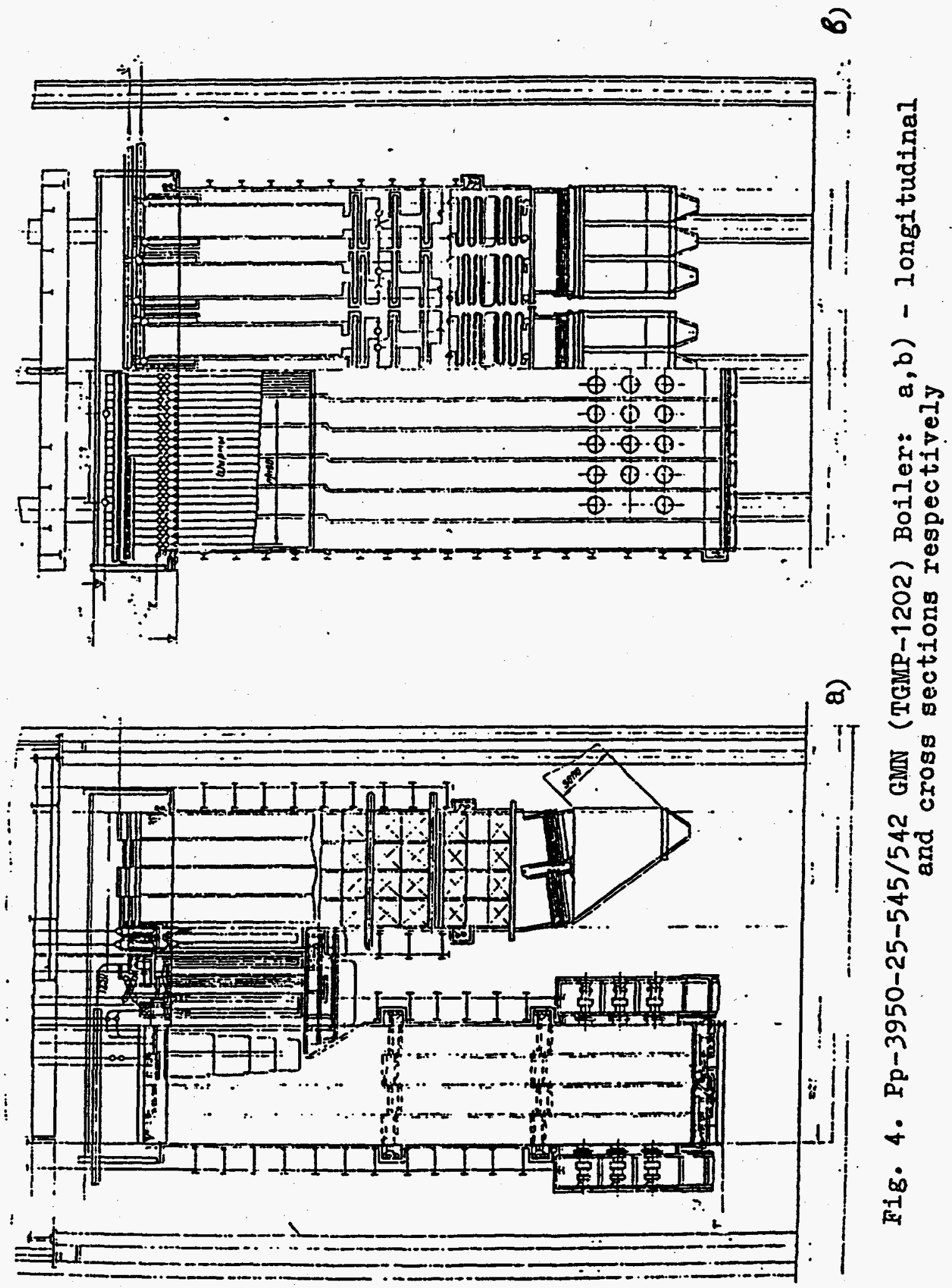




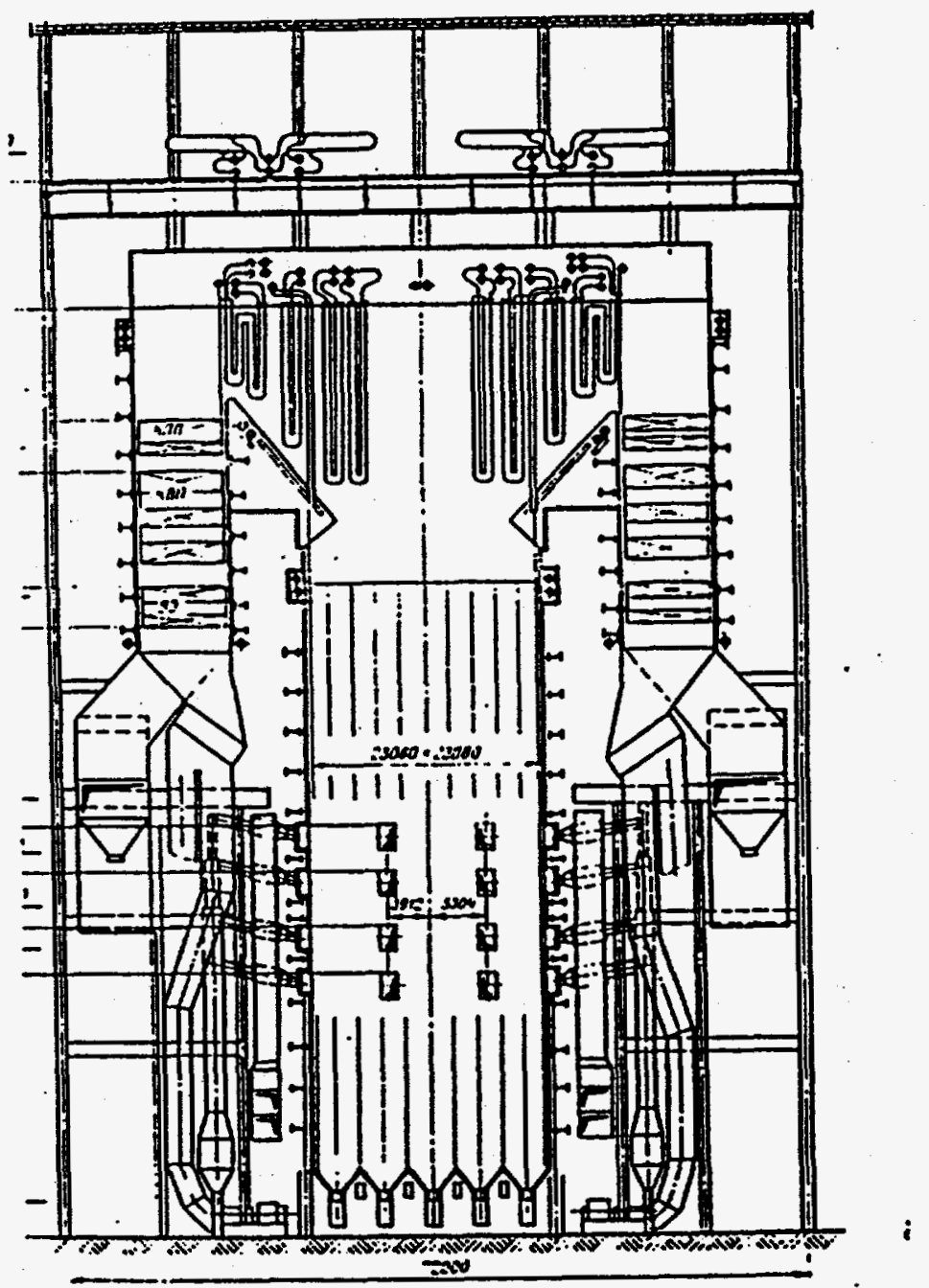

Fig. 5. Pp-2650-255 (P-67) Boiler (cross-section) 

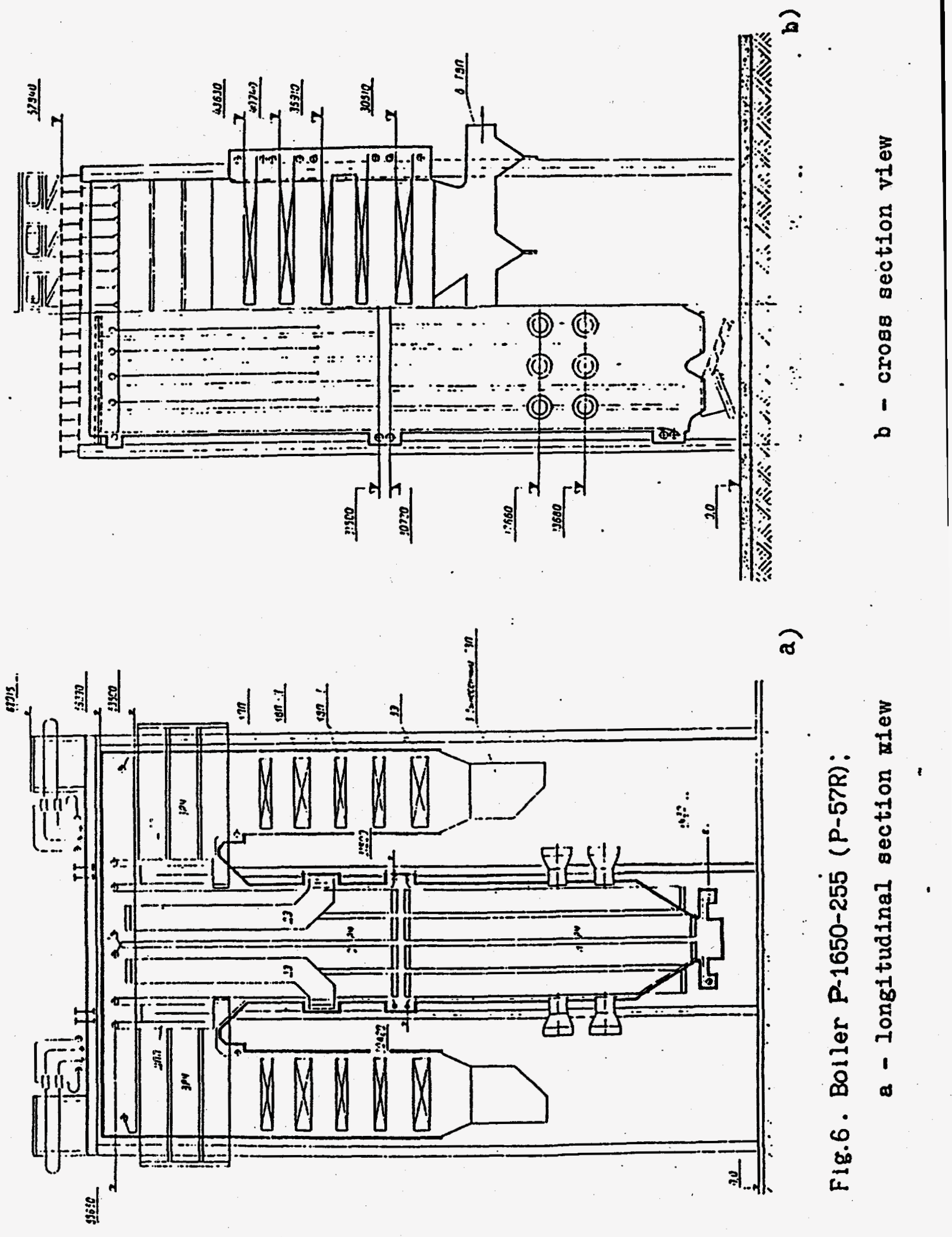


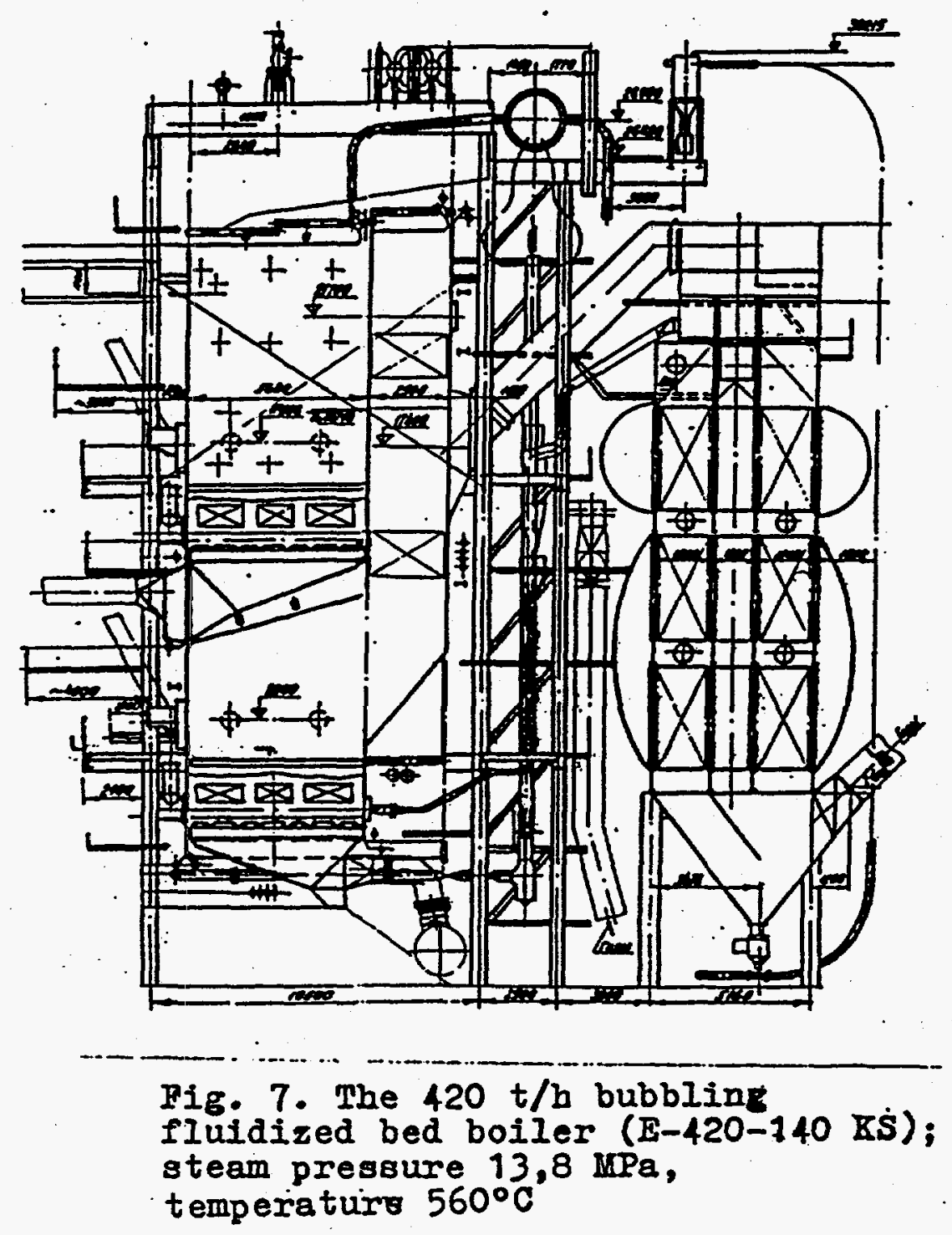



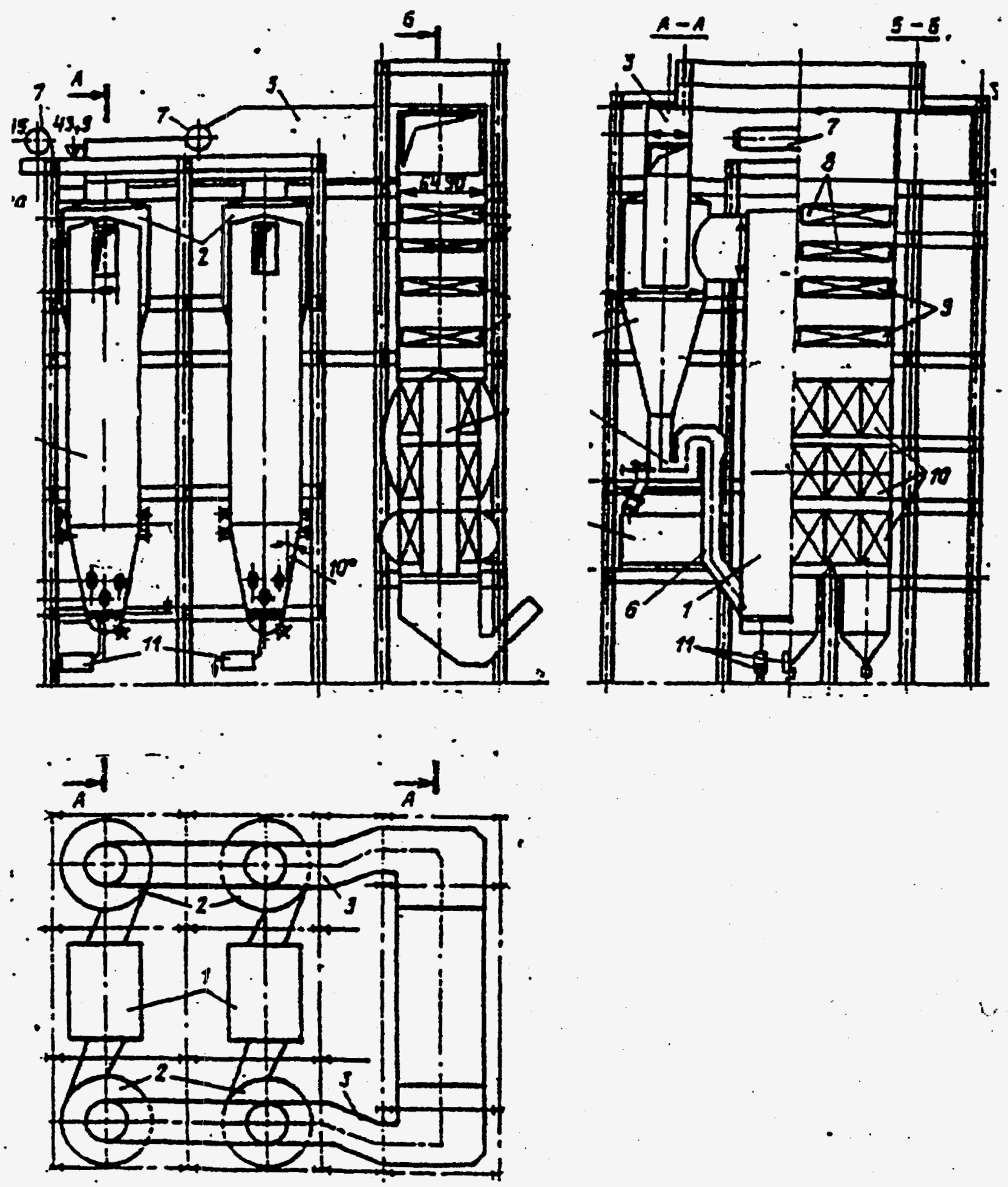

- Pig..8. Demo 500 t/h CFB boiler 


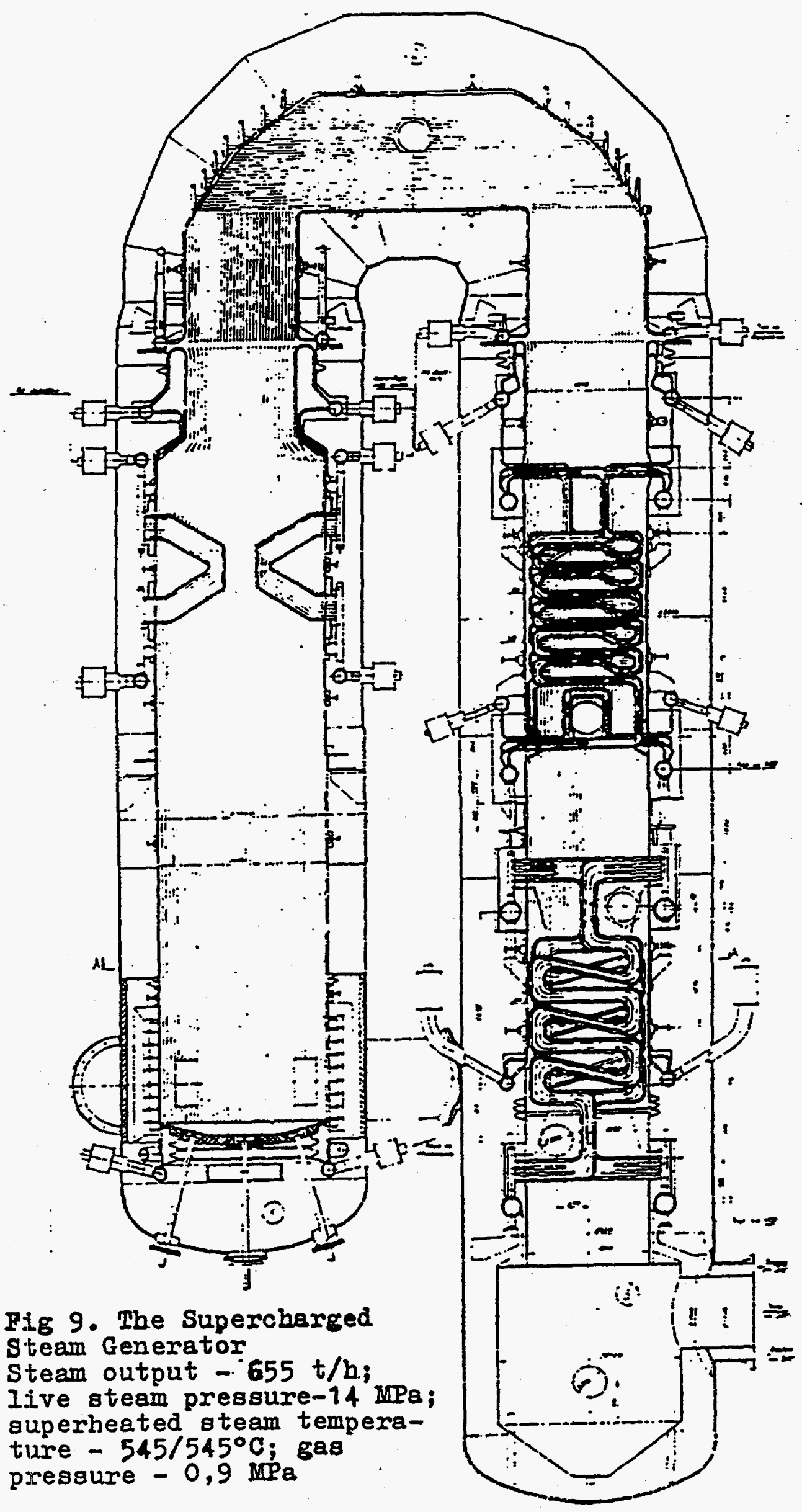




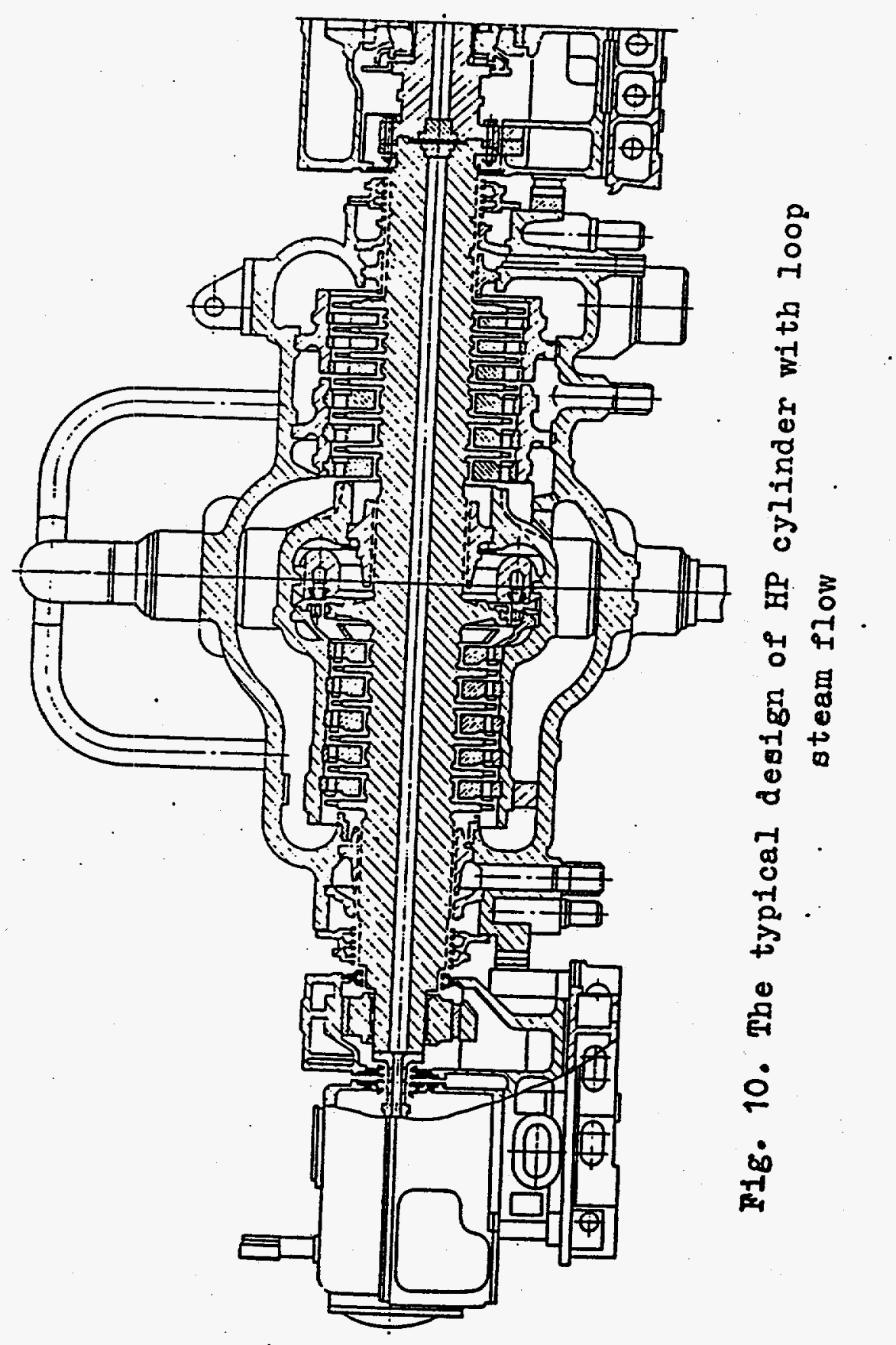




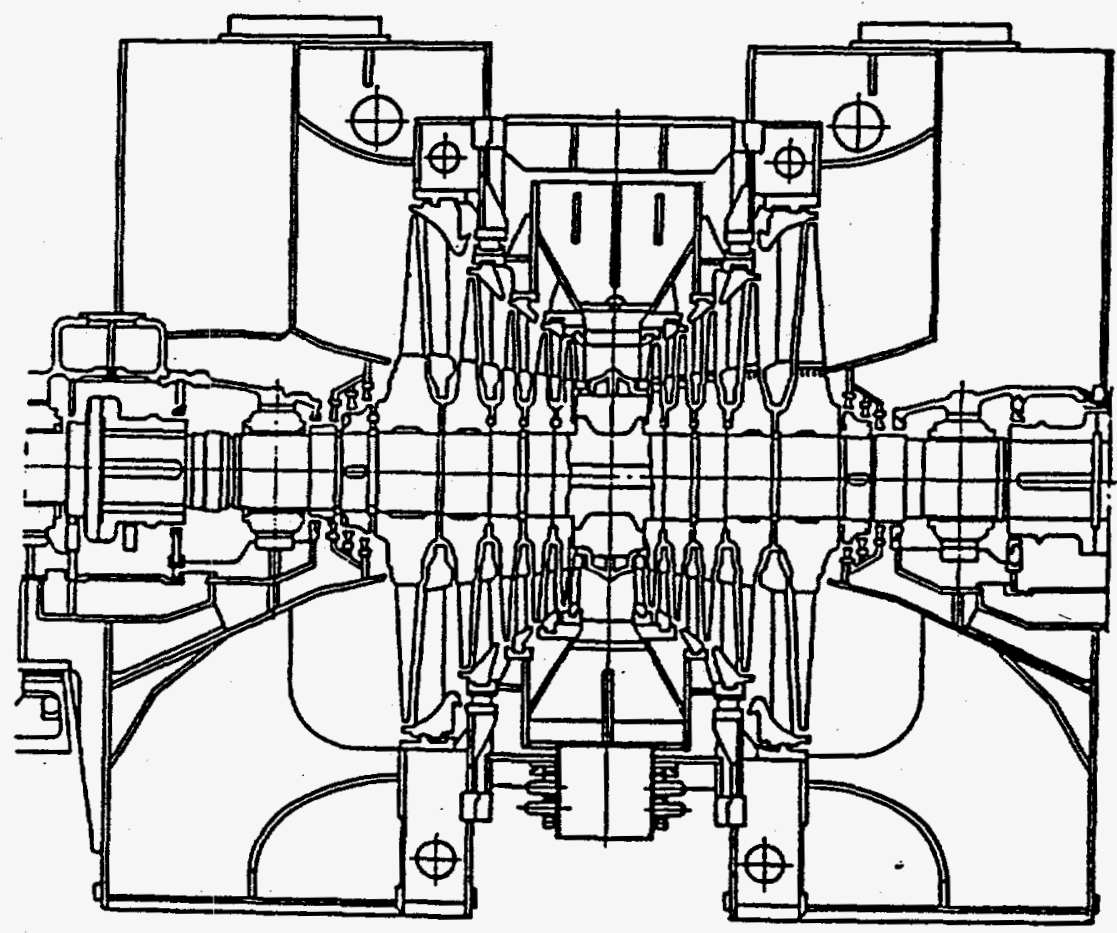

Pig. 11. The typical IP cylinder 


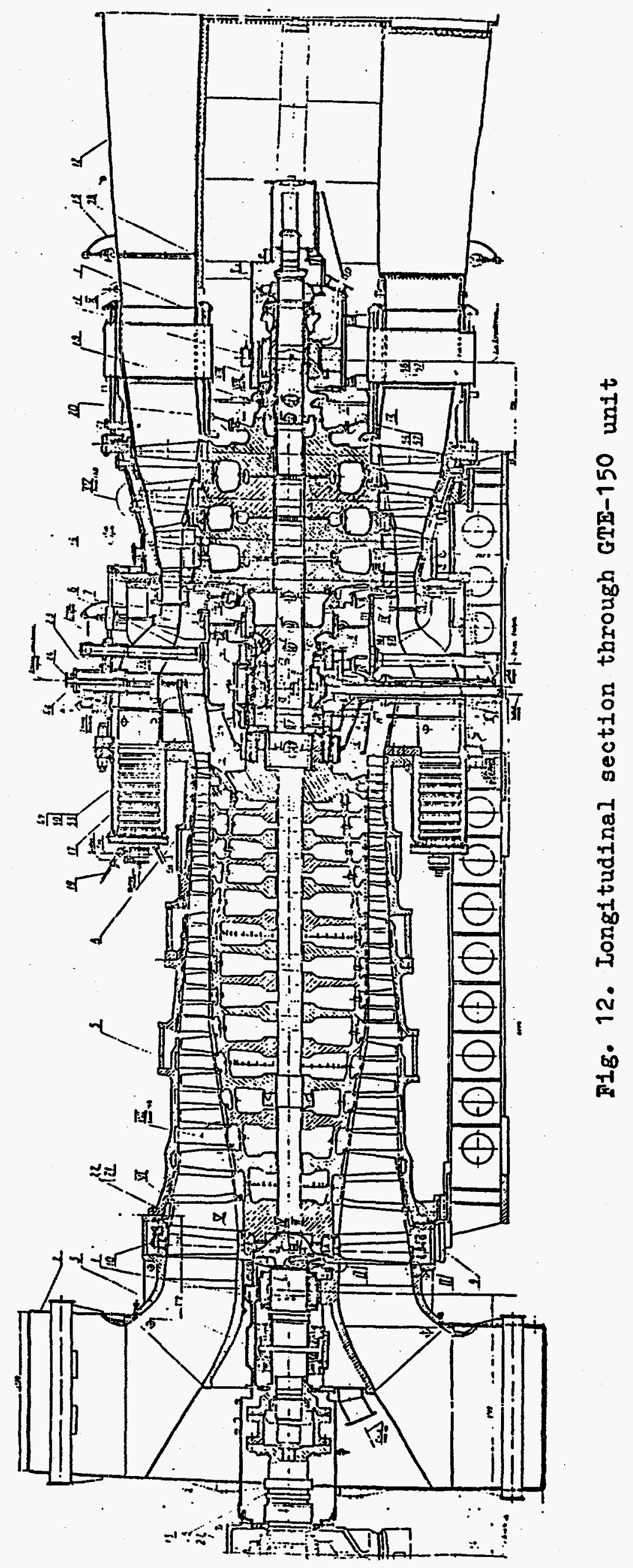




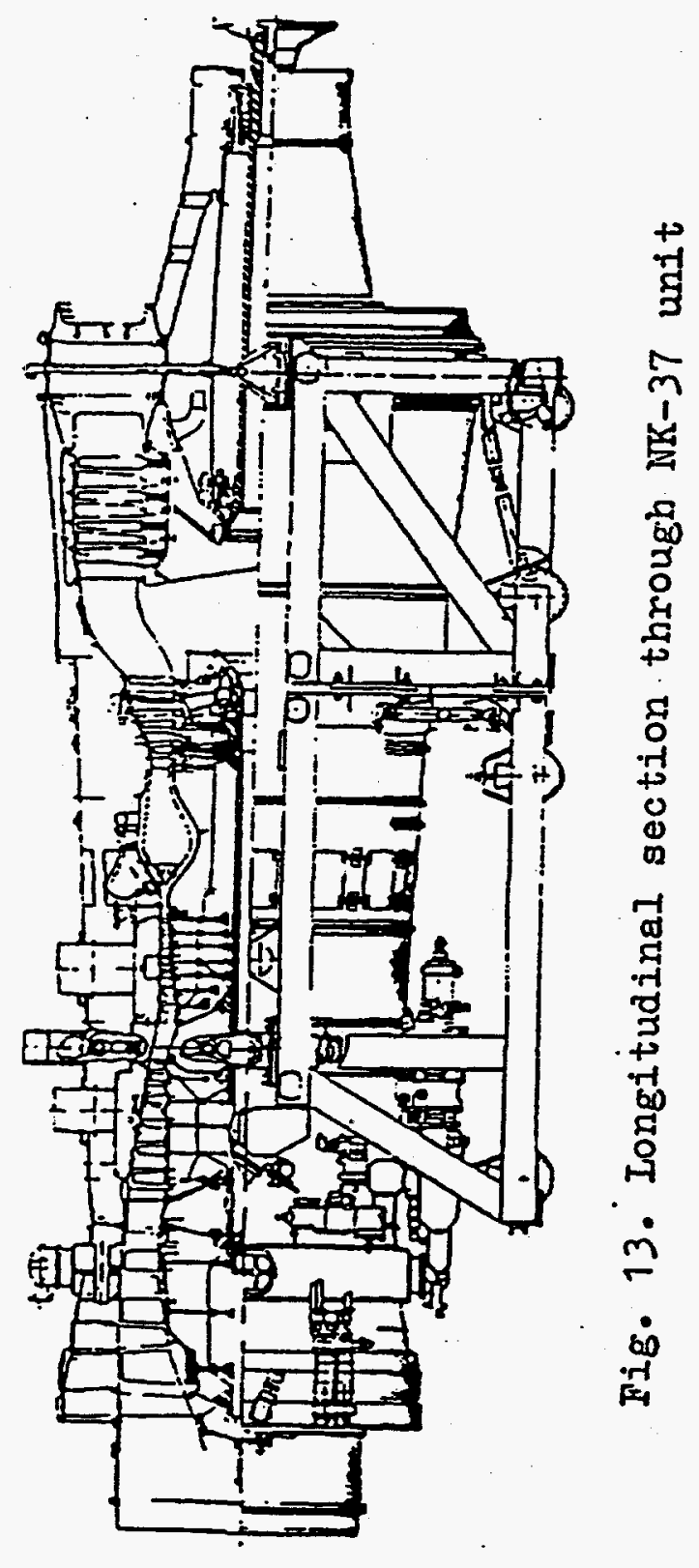



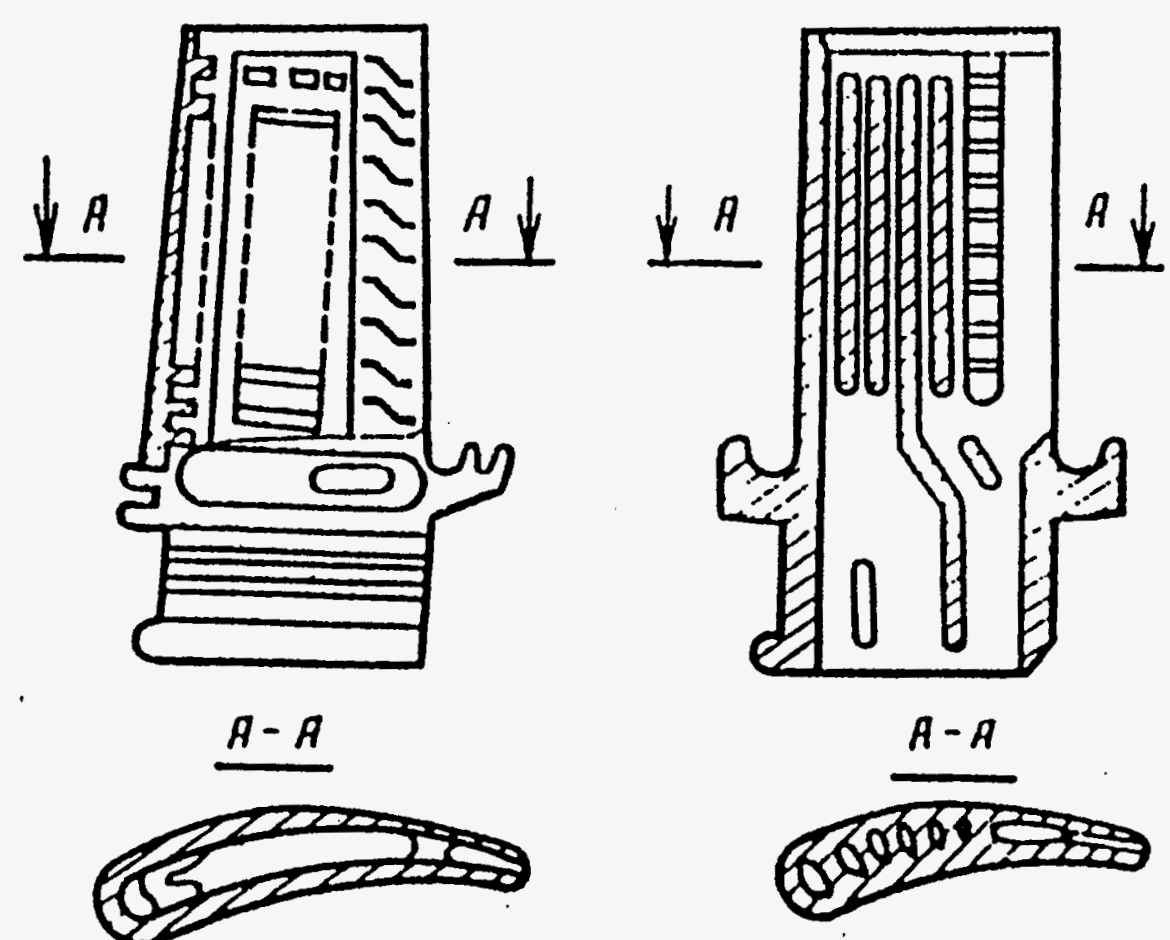
a)
b)

e)

Fig. 14. The first stage buckets with various internal cooling
a - air deflector
b - serpentine
c - vortex 


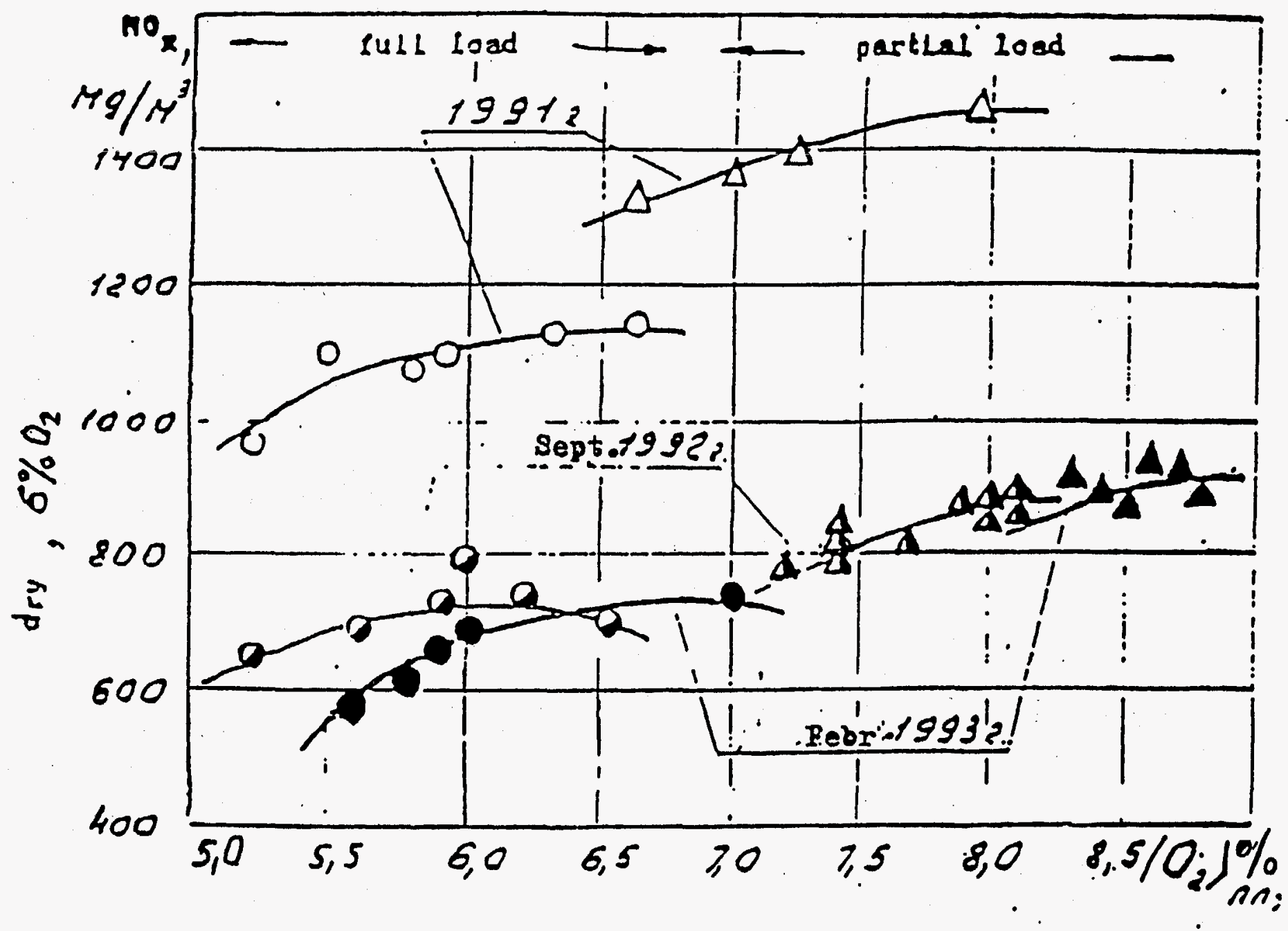

Fig. 15. NOx emission versus $\mathrm{O}_{\mathrm{e}}$ after superheater before (1991) and after (1992-93) regenstruction. Boiler $420 \mathrm{t} / \mathrm{h}$; brown coal 


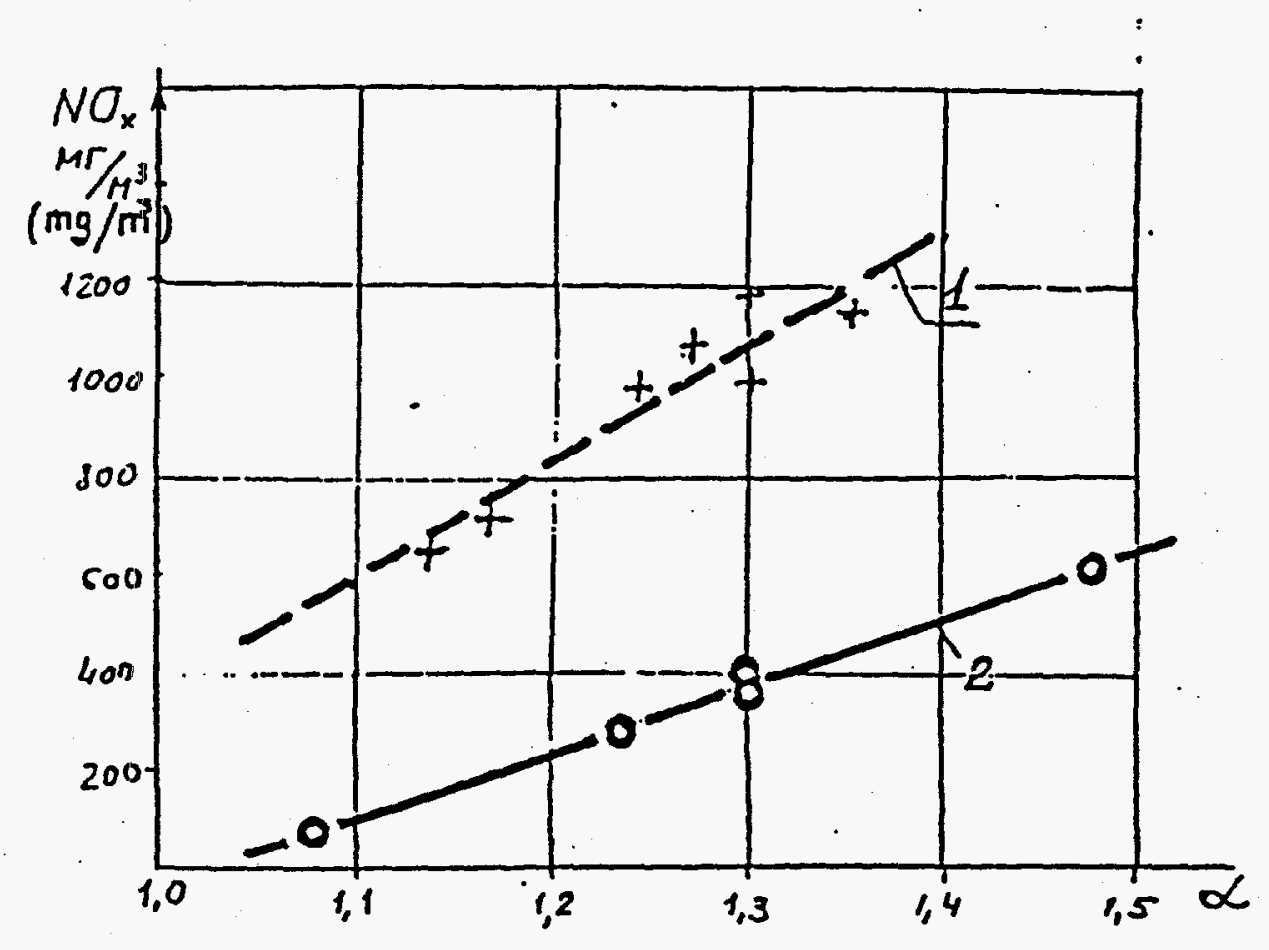

Pig. 16. NOx emissions when bigb concentrated pulverized coal mixture is fired

1 - coal entrance before burner; 2 - coal entrance in burner throat; $\alpha$ -furnace outlet excess air coefficient 


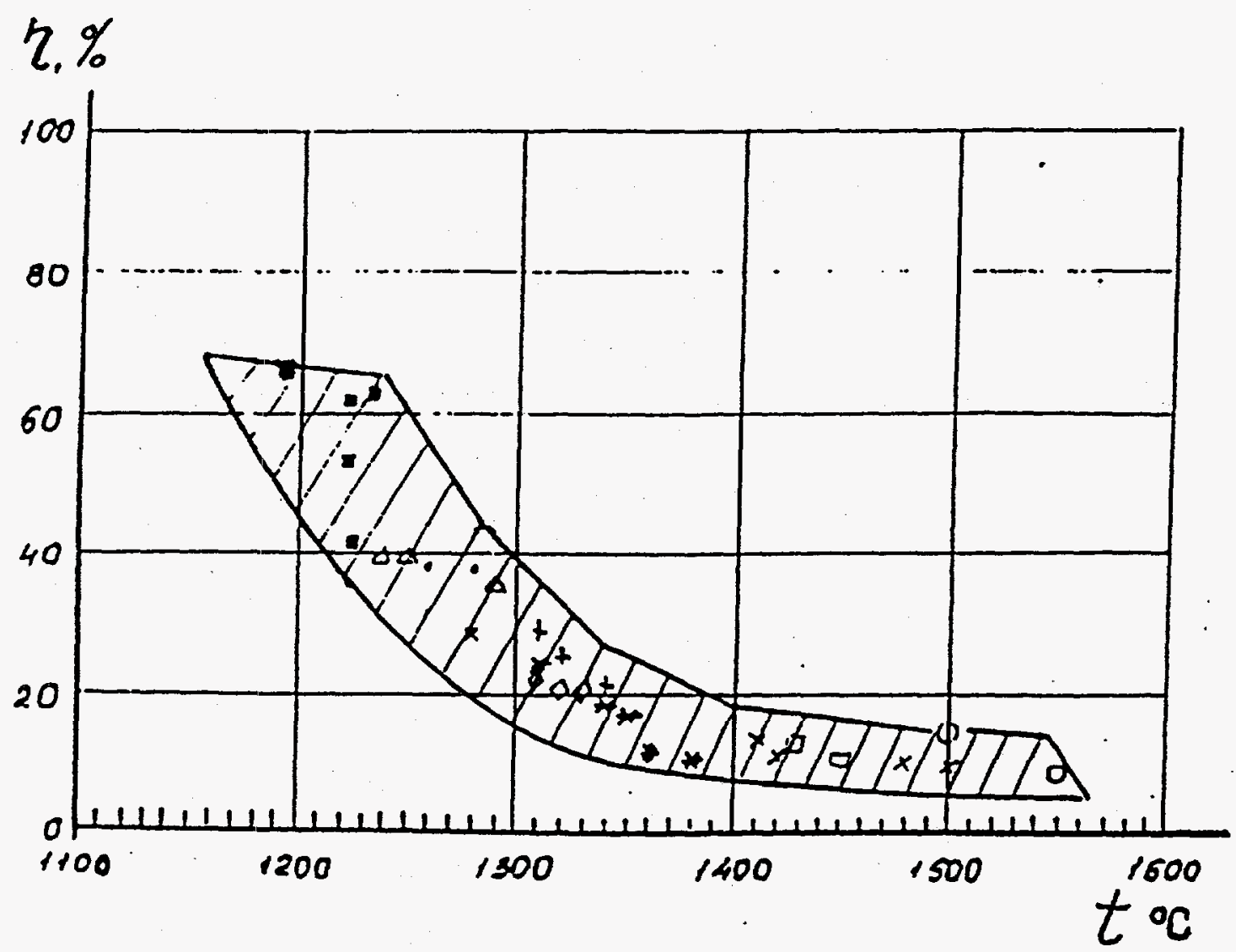

Fig. I7.Sulfur fixation by fly ash in boilers firing $X-A$ coals 


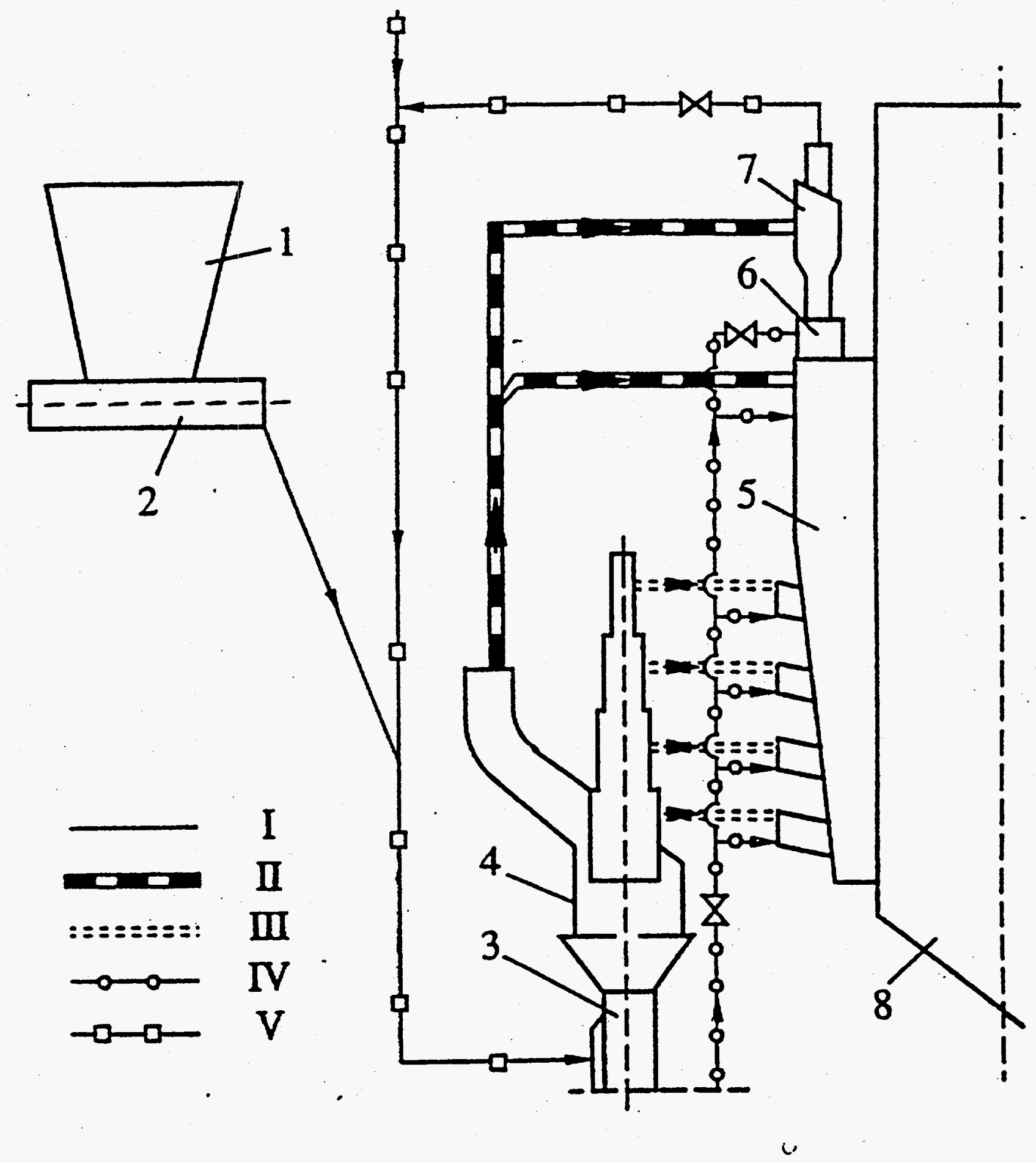

Fig. 18. The coal pulverizing system

with an installation for high-temperature powder heating ( (2) raw coal feeder; (3) uN 3400 fan-pulverizer;

(4) coal-powder concentrator; (5) coal-powder beater;

(6) muffle burner:; (7) cyclone; (8) furnace; (I) fuel; (II) coal-powder-air mixture (concentrated atream); (III) coal-powder-aIr mixture (Iow-powdery stream); (IV) bot air; (V) Ilue gases 


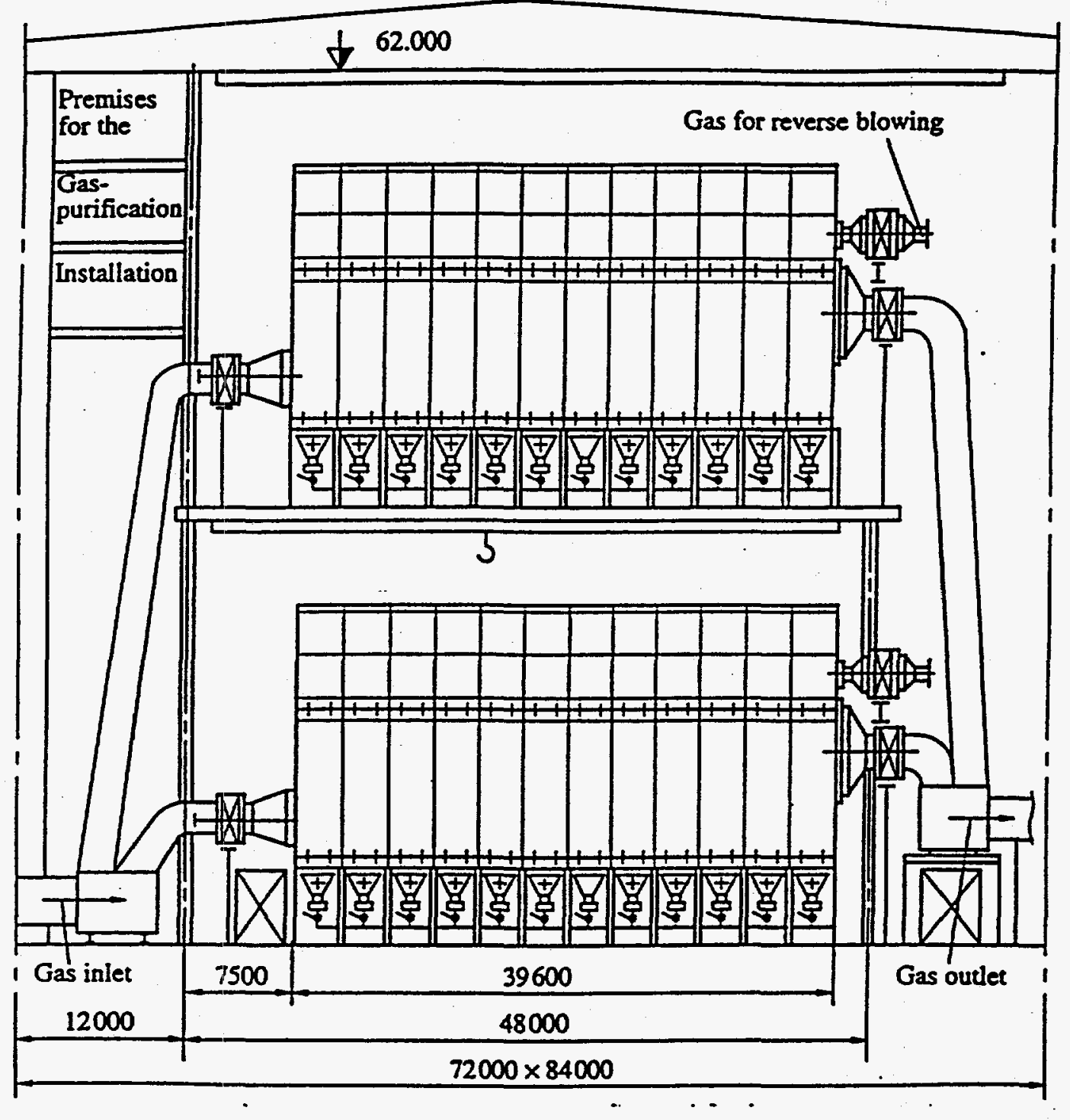

Fig. 19. Two-storey baghouse with FRO-12000 filter 


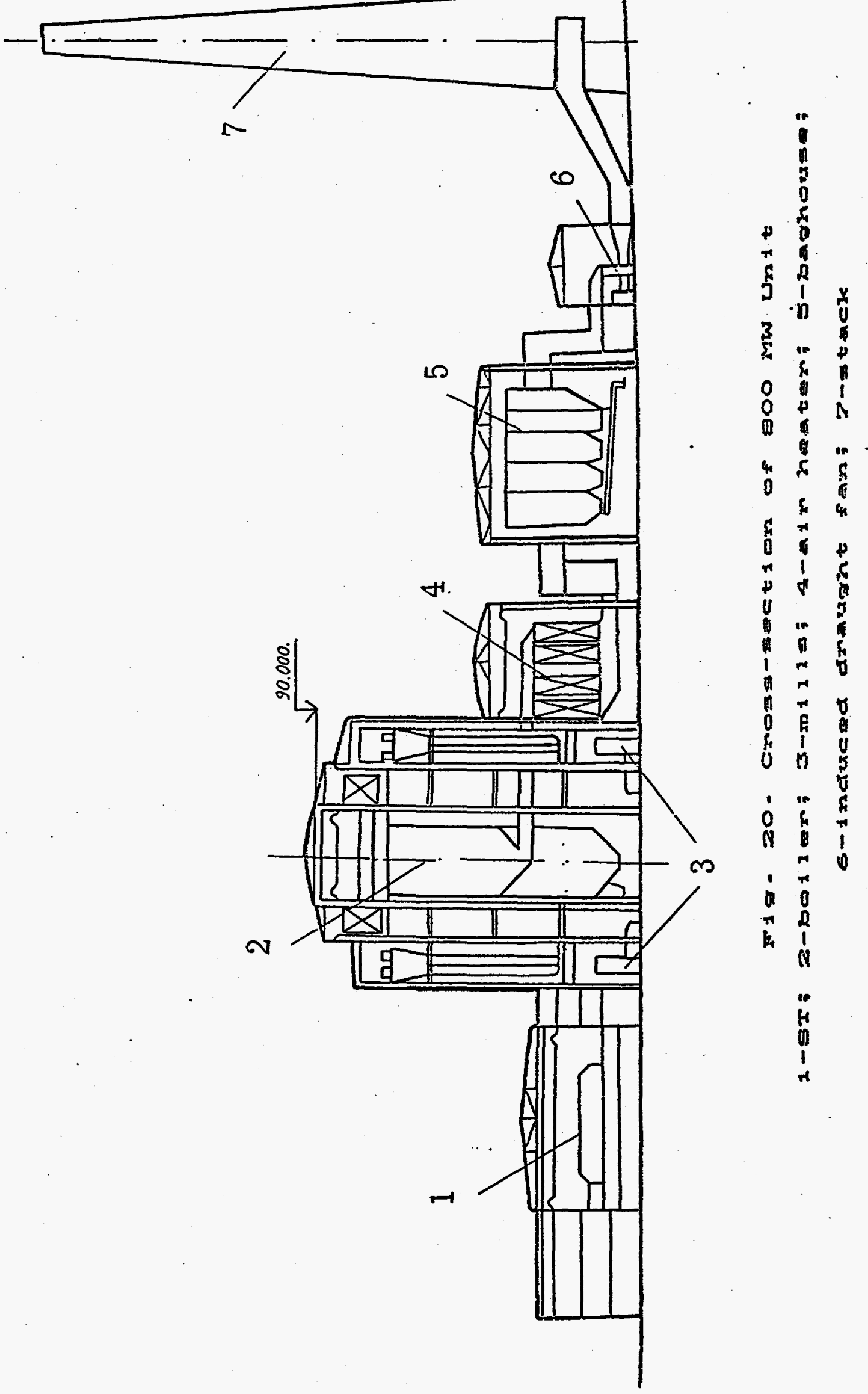




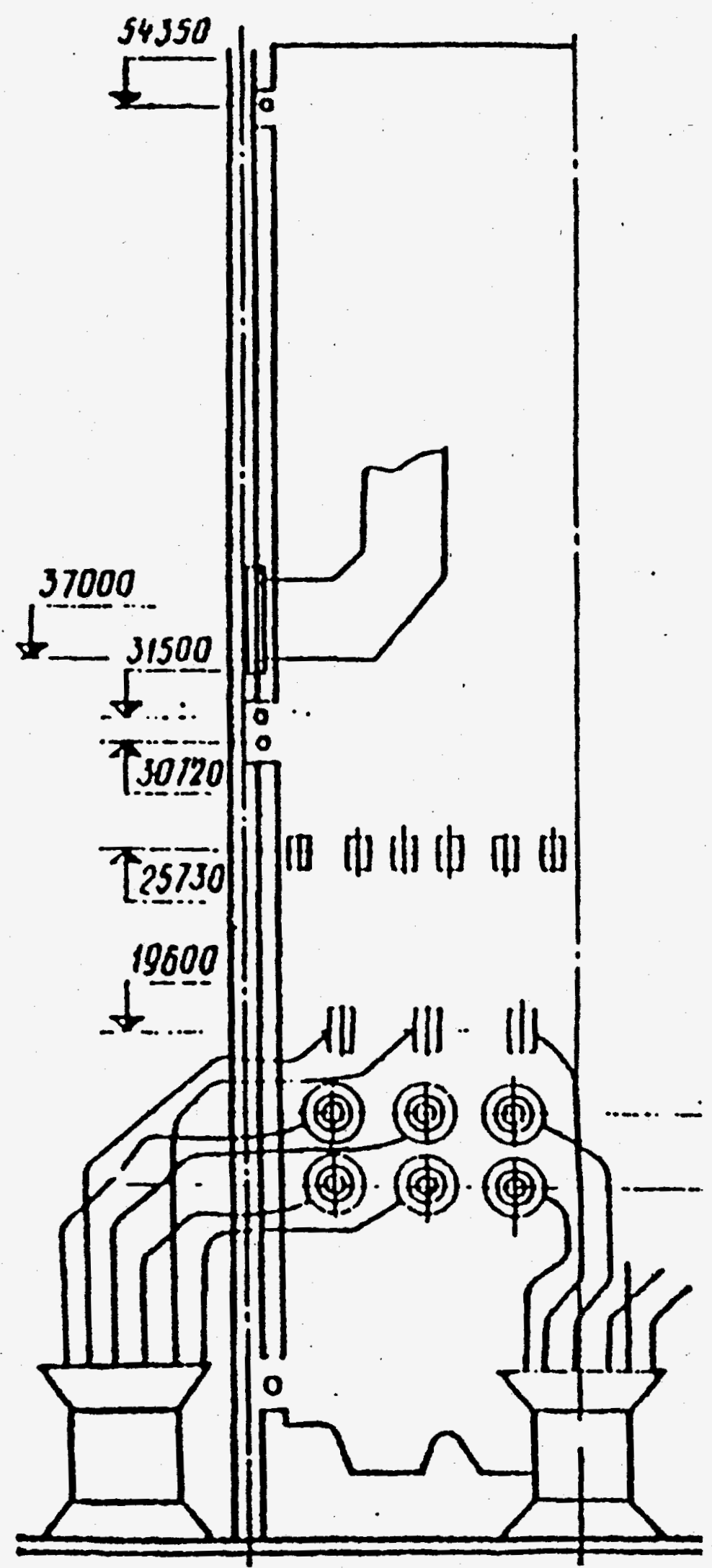

Fig. 21. The layout of the furnace: - with in-wall vortex burners 


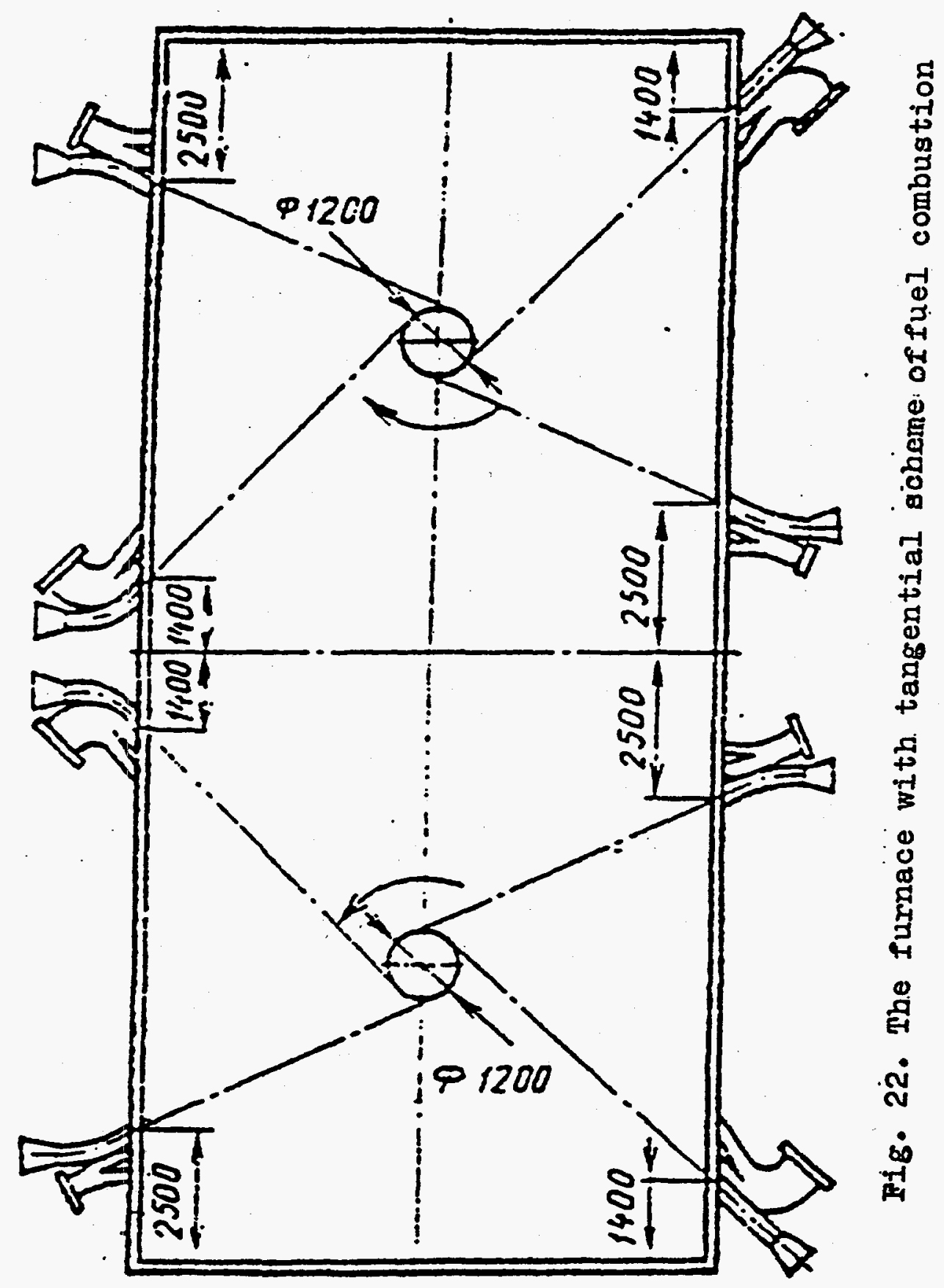




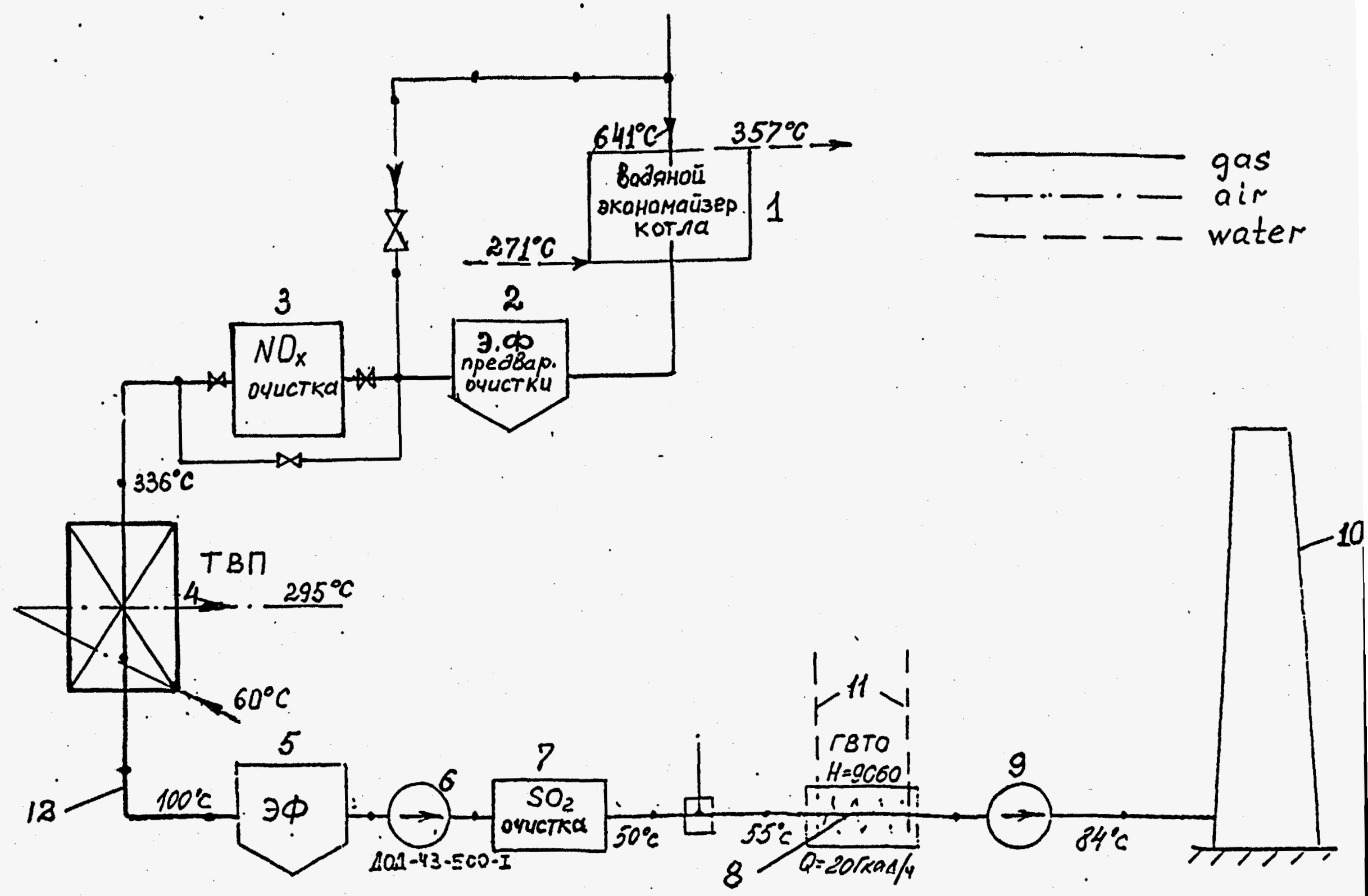

Fig. 23. Low Temperature 500 KK Unit's Boiler Path with High Dust DehOx

1-econoniser: 2-hot ESP: 3-DeHOx; 4-air heater: 5-rain ESP: 6-nain induced draught fan; 7-DeSOx; 8-gas heater; 9-aux1llary induced draught fan; 10-stack; 11-hot water for gas heating: 12-flue gases 


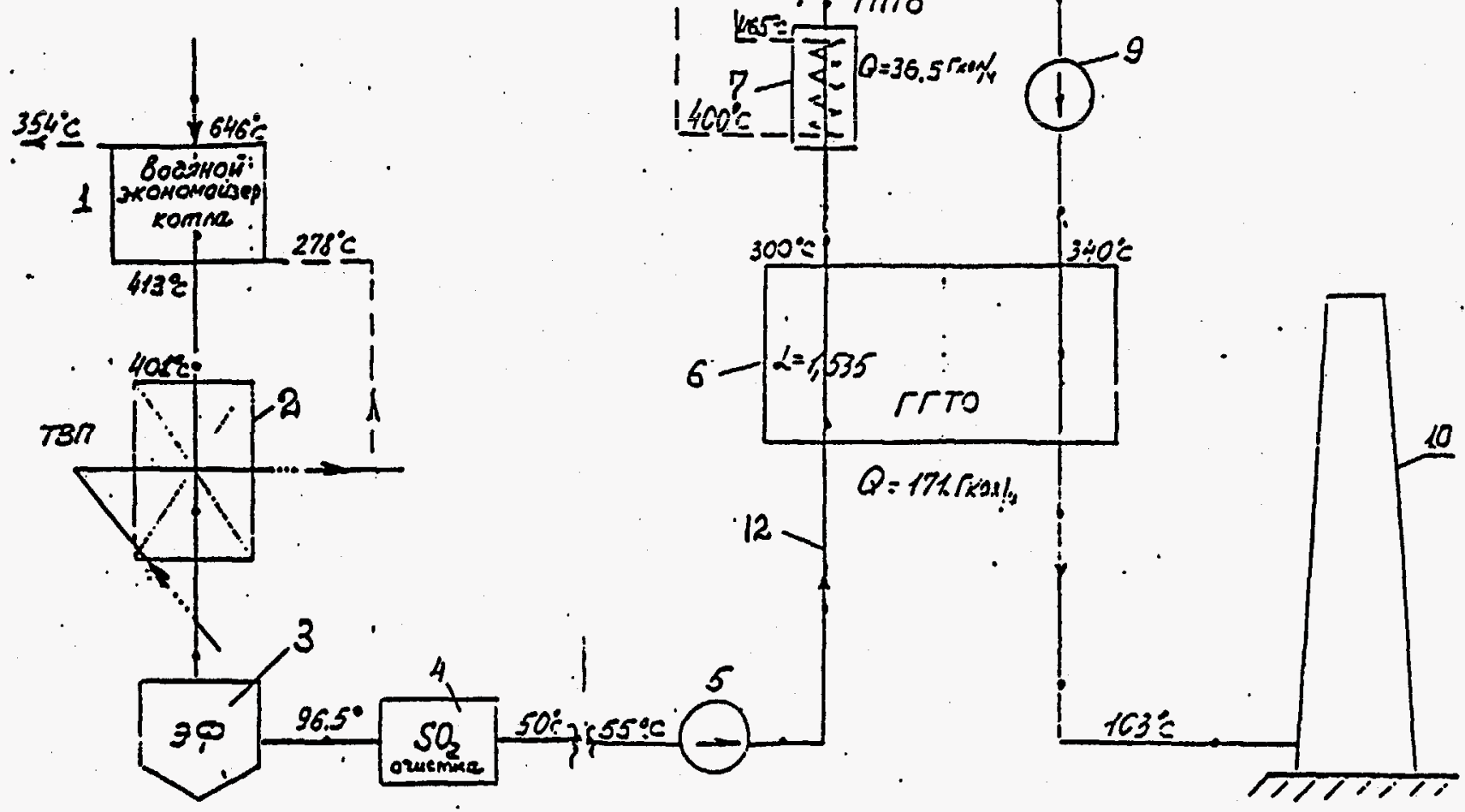

F1g. 24. Lou Temperature 500 uR Onlt's Boller Path uIth Lov Dust Del0x

1-econou1ser: 2-air heater: 3-nain ESP: 4-DeSOx system: 5-main Induced draught fan: 8-convectlue gas heater-cooler: 7-h1 gh temperature gas heater: 8-Dellox:

9-auxillary Induced draught fan; 10-stack: 11-superheated stean for gas heating: 12-flus gases 


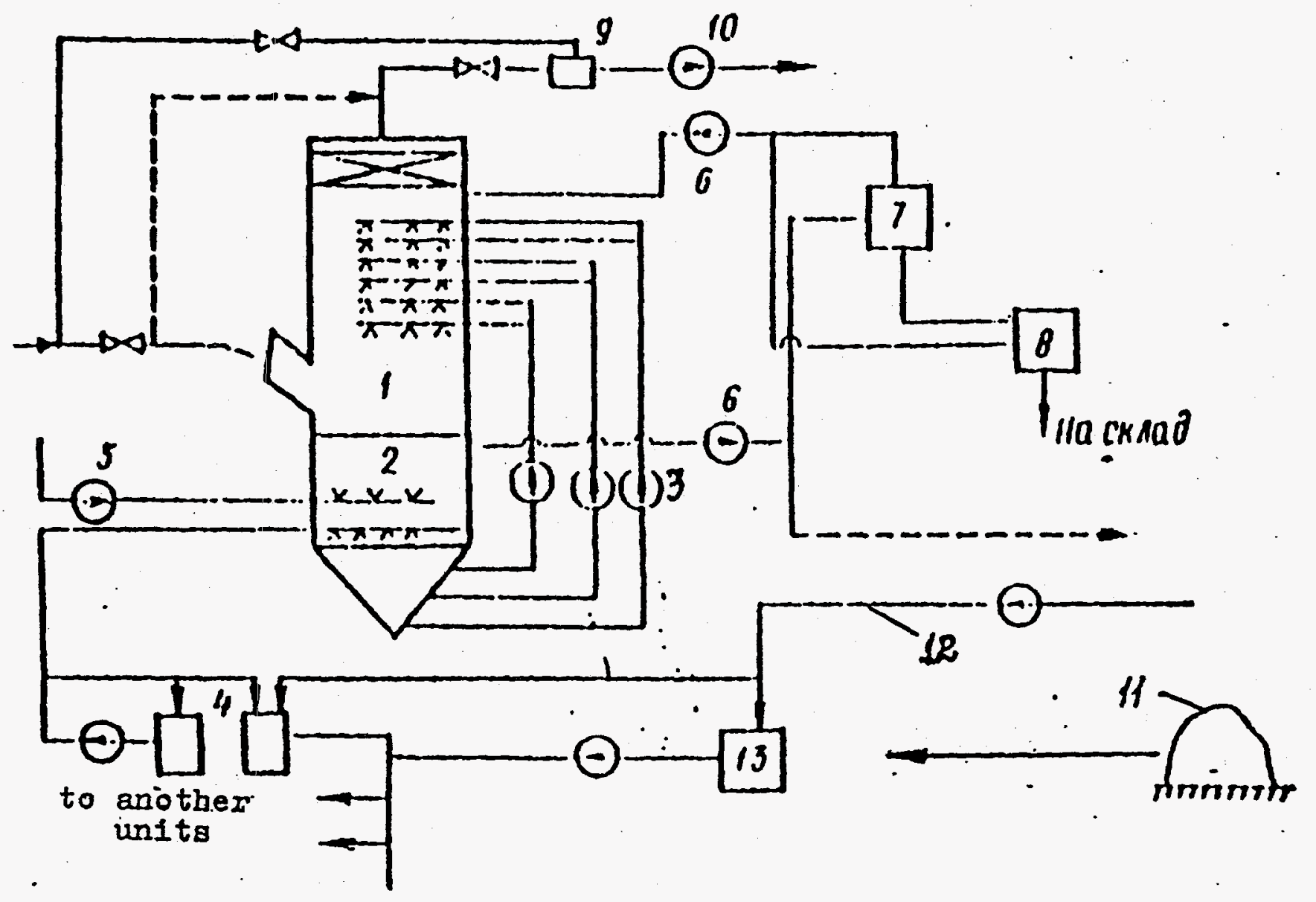

Fig. 25. Wet DeSOx System

1 - scrubber; 2 - water collected part; 3 - slurry recirculating pump; 4 - olurry tanks; 5 - oxydizing air blower; 6 - waste olurry and sludge pump; 7 - bydrocyclone; 8 - centrifuge; 9 - gas beater; 10 - Induced-draught fan; 11 - Inestone; 12 - water; 13 - slurry preparation 


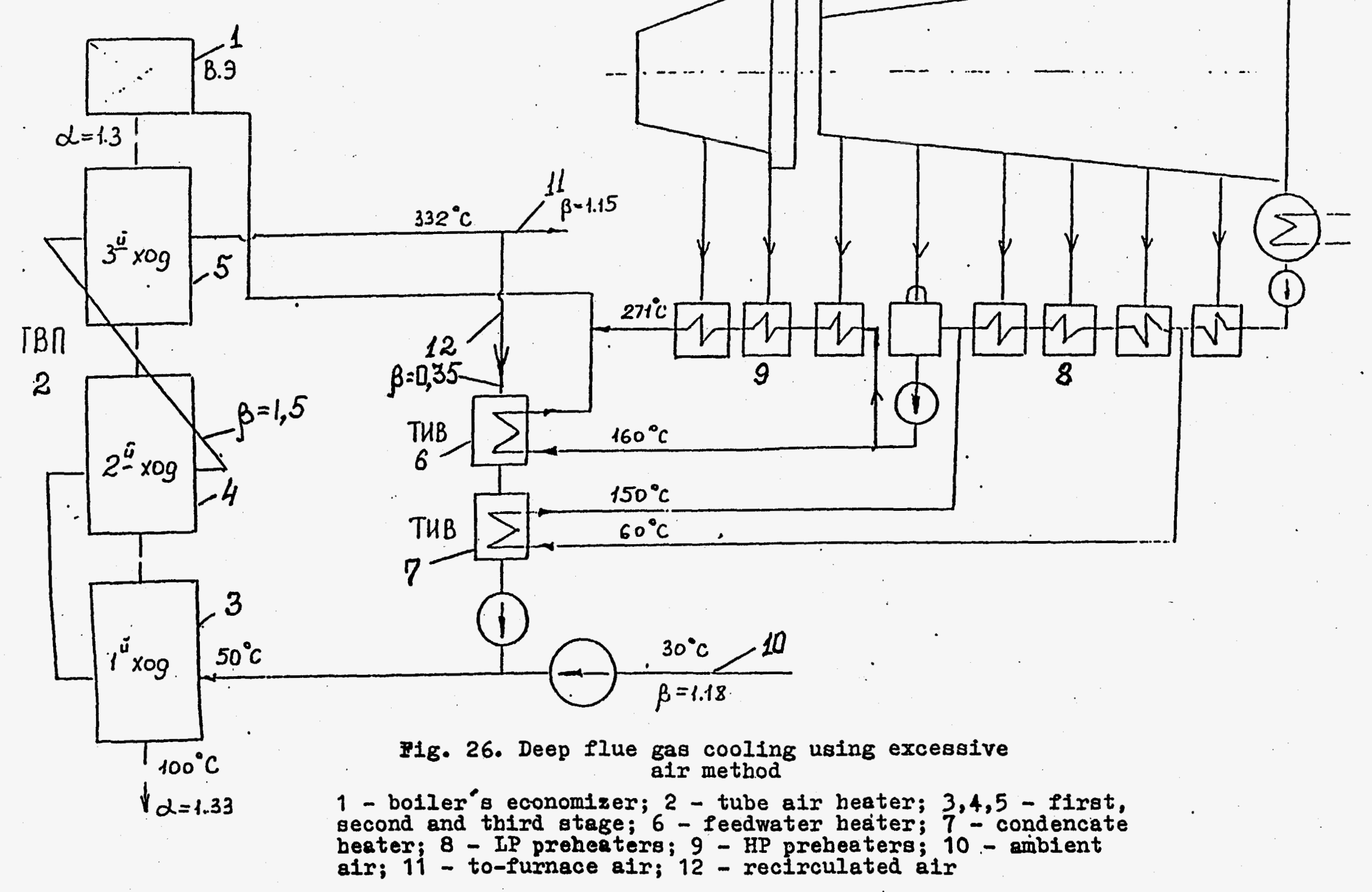




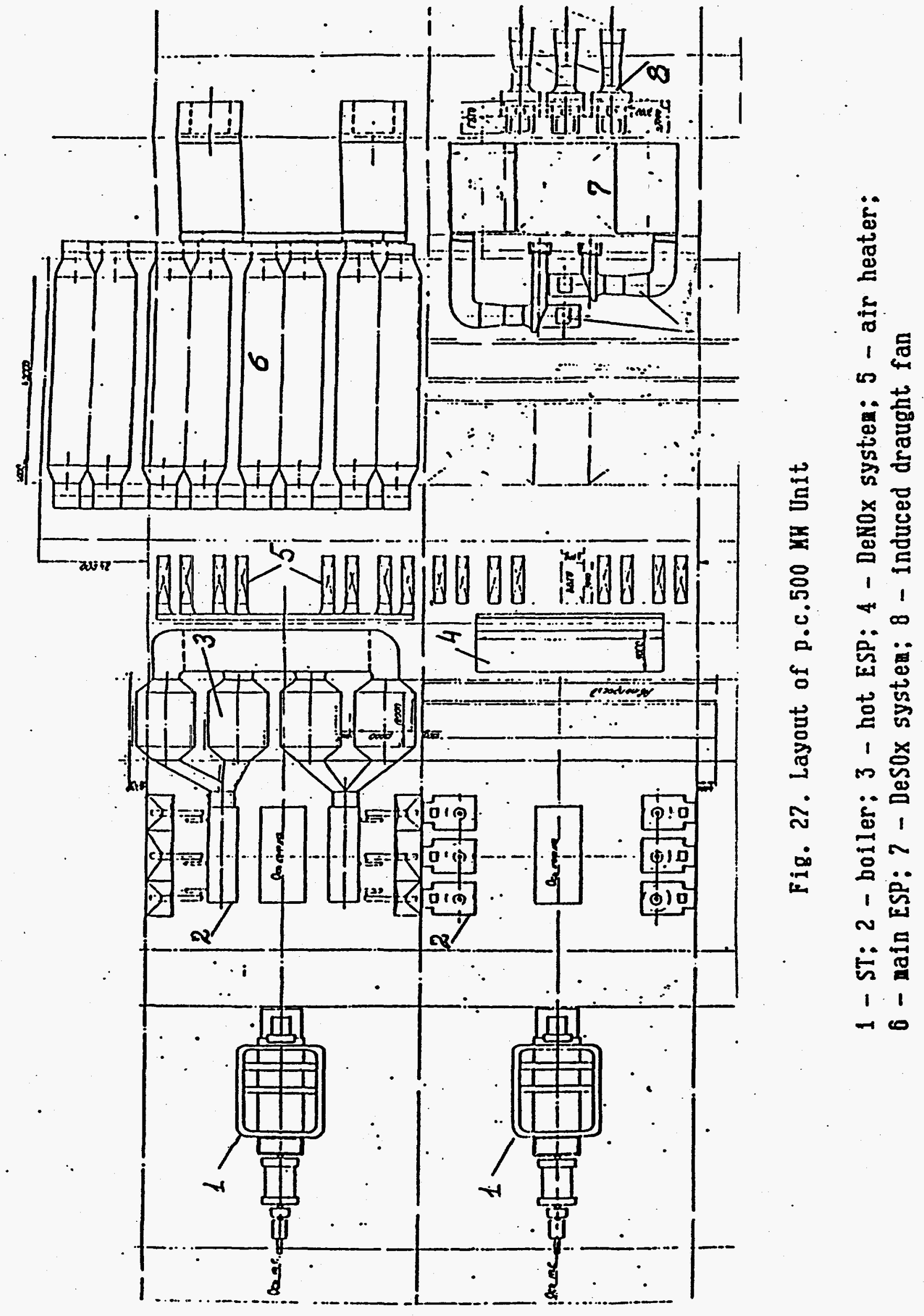




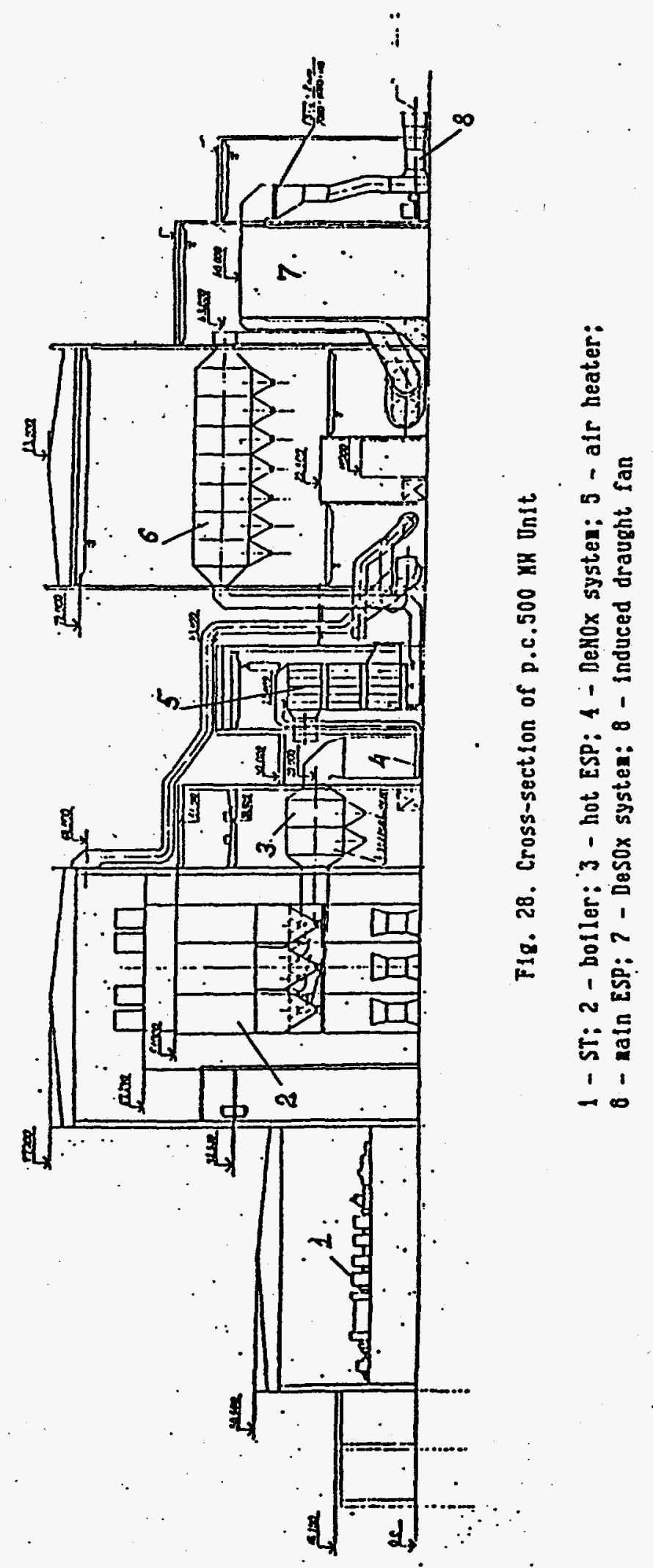




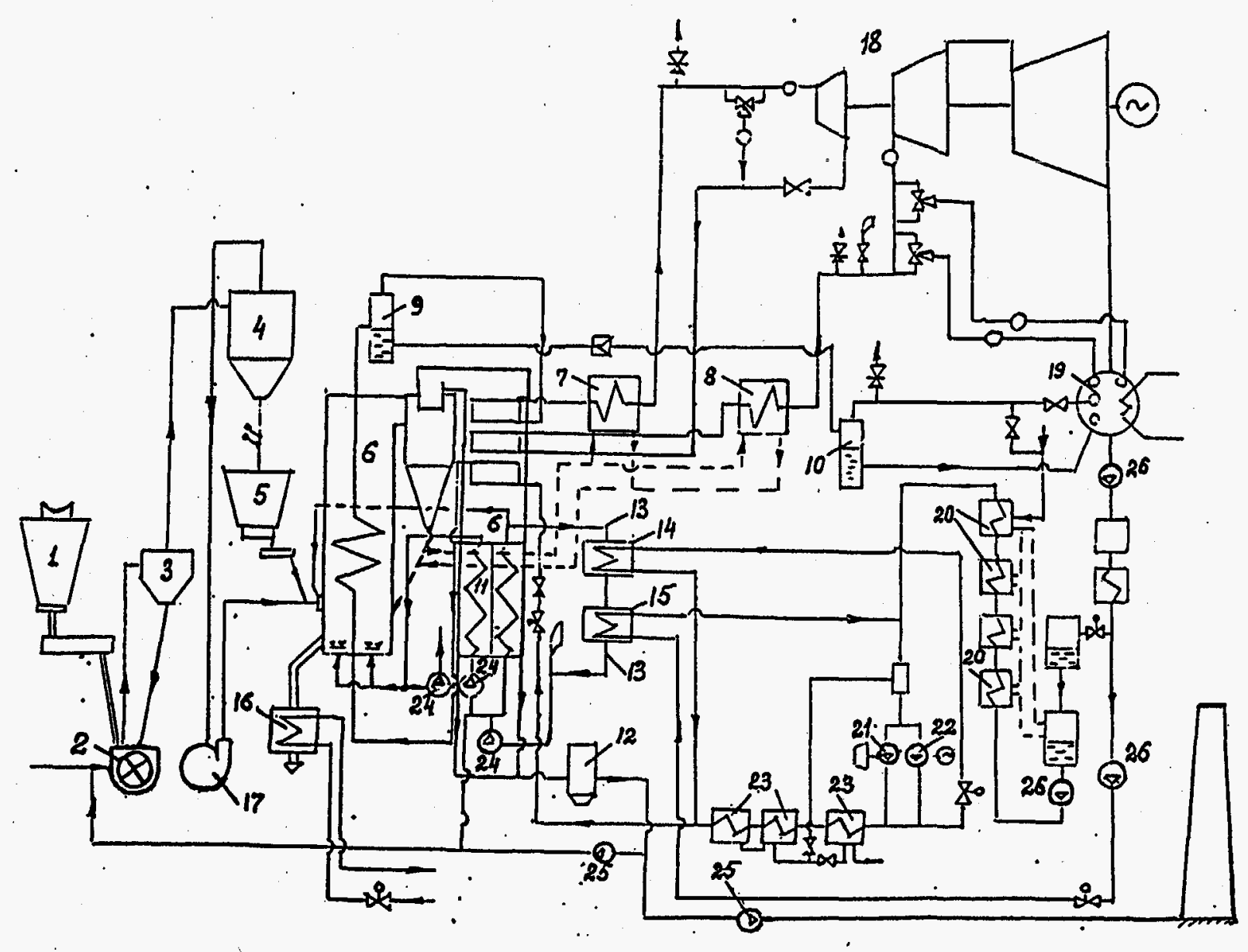

1. rav coal hopper

2. hanner ulll

3. separator

4. cyclon

5. day hopper

6. furnace and gas path

7. Live stean-ash heat exchanger

8. reheat stean-ash heat exchanger

9. full flow separator

10. starting separator

11. afr preheater

12. ESP

13. overflow air

14. BP alr-water heater

15. LP air-water heater

10. discharged bed ash cooler

17. for nlll air fan

18. stean turbine

19. condenser

20. LP stean-water preheaters

21. feed vater turbo punp

22. feed water electrical punp

23. HP stean-vater preheaters

24. forced draft fans

25. Induced draft fans

26. condensate punps

Fig. 29. Schenatic of a CFB boller with X-300-240 Turbine 


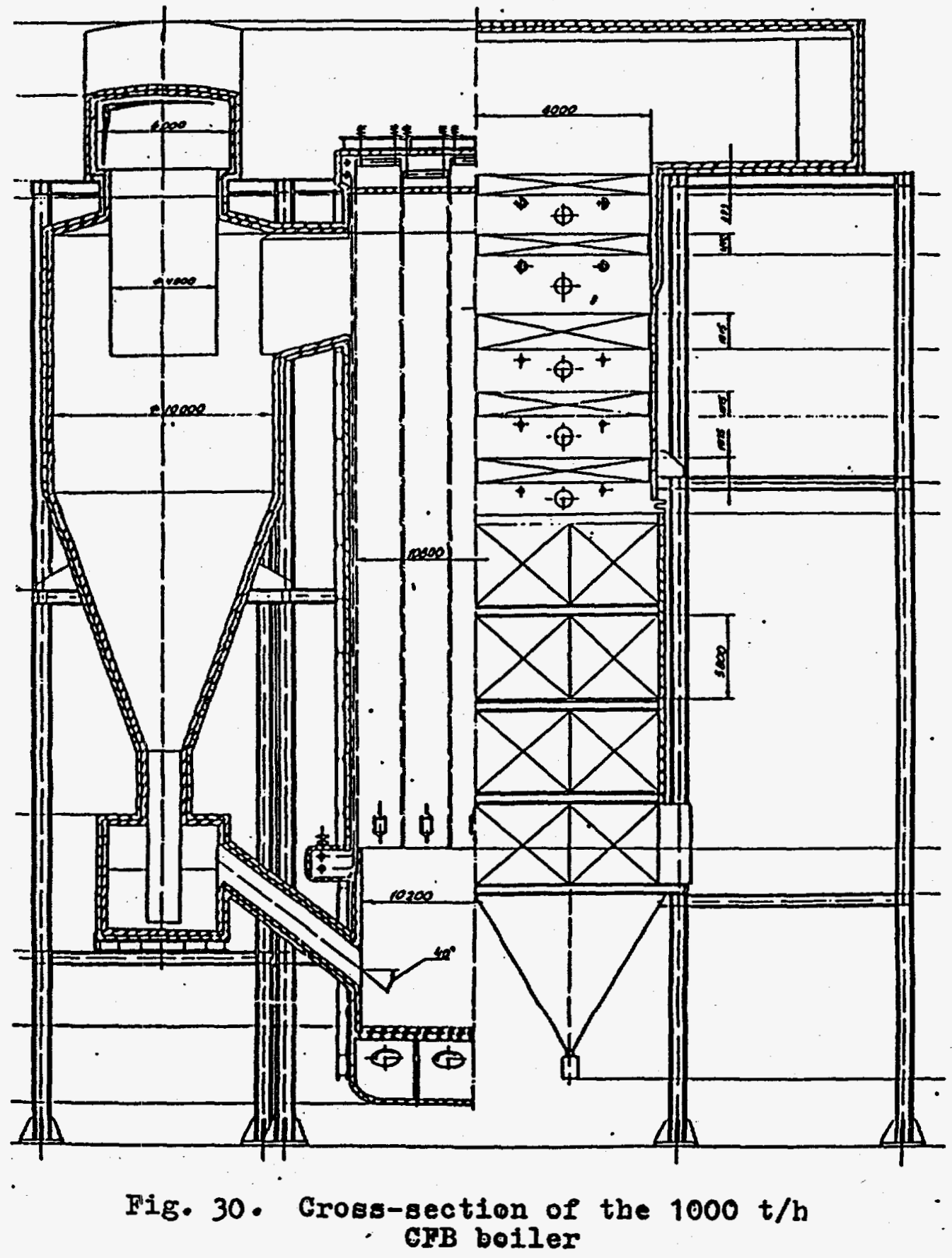




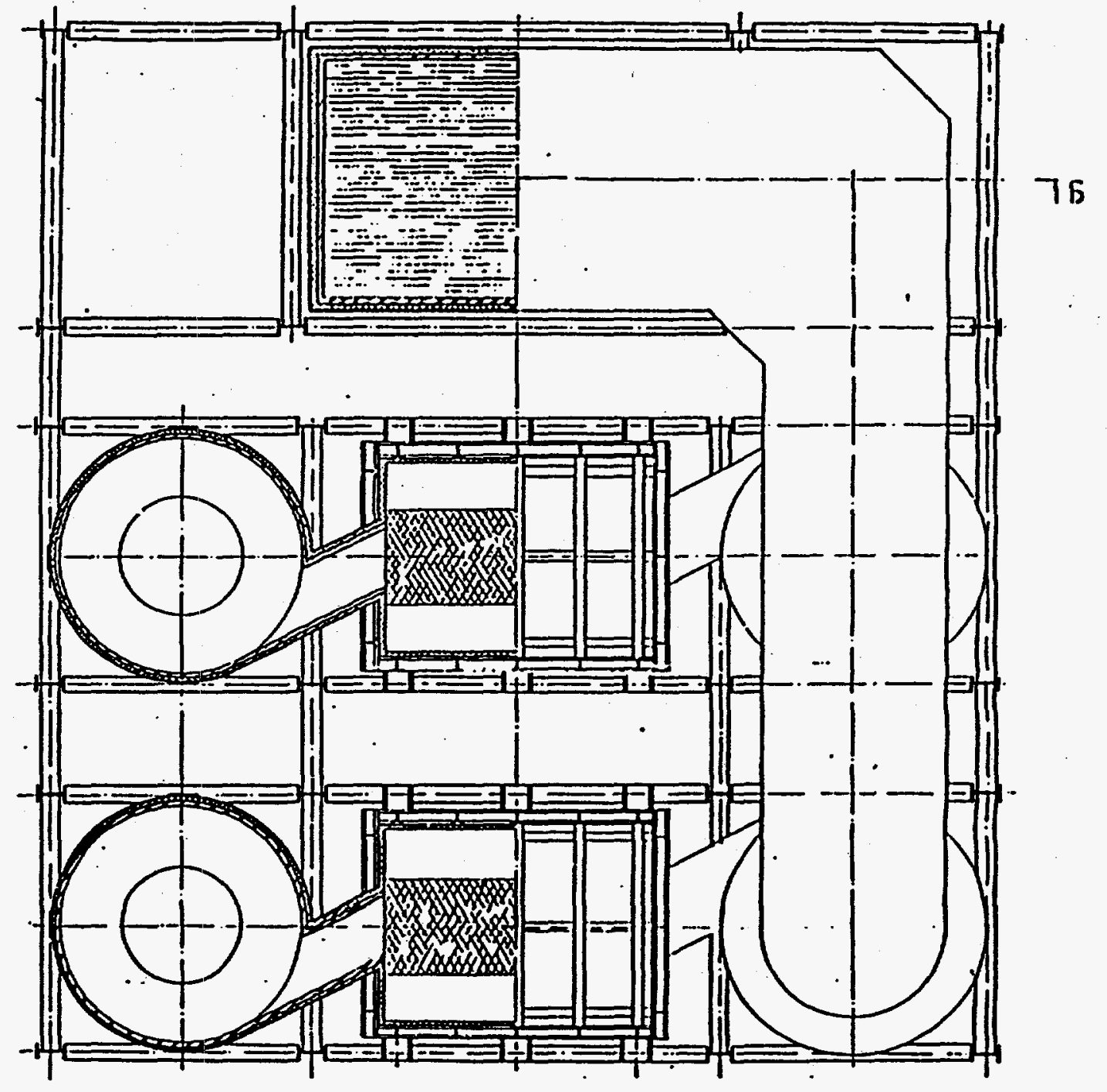

Fig. 31. The layout of the $1000 \mathrm{t} / \mathrm{h}$ CFB boiler 

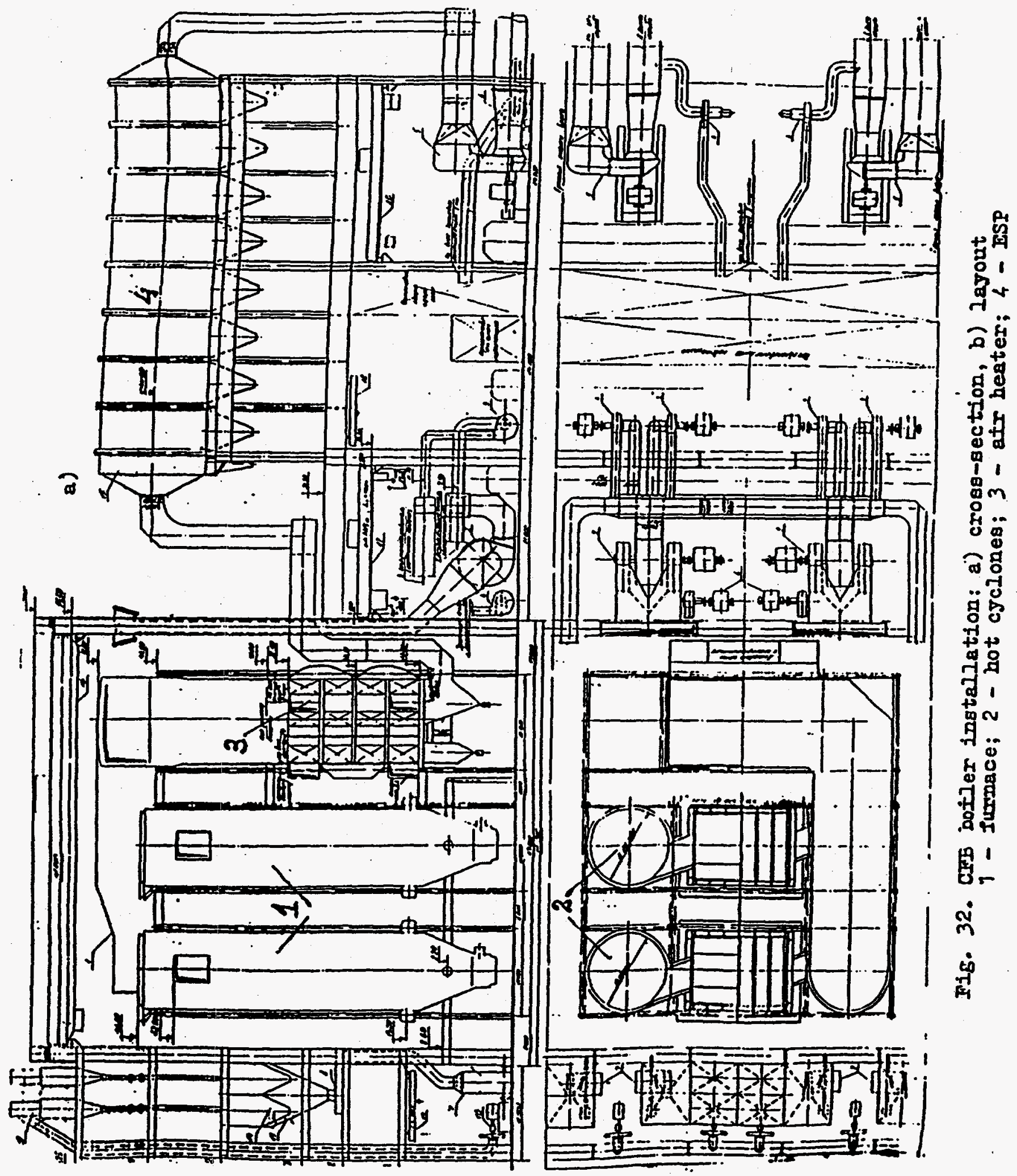


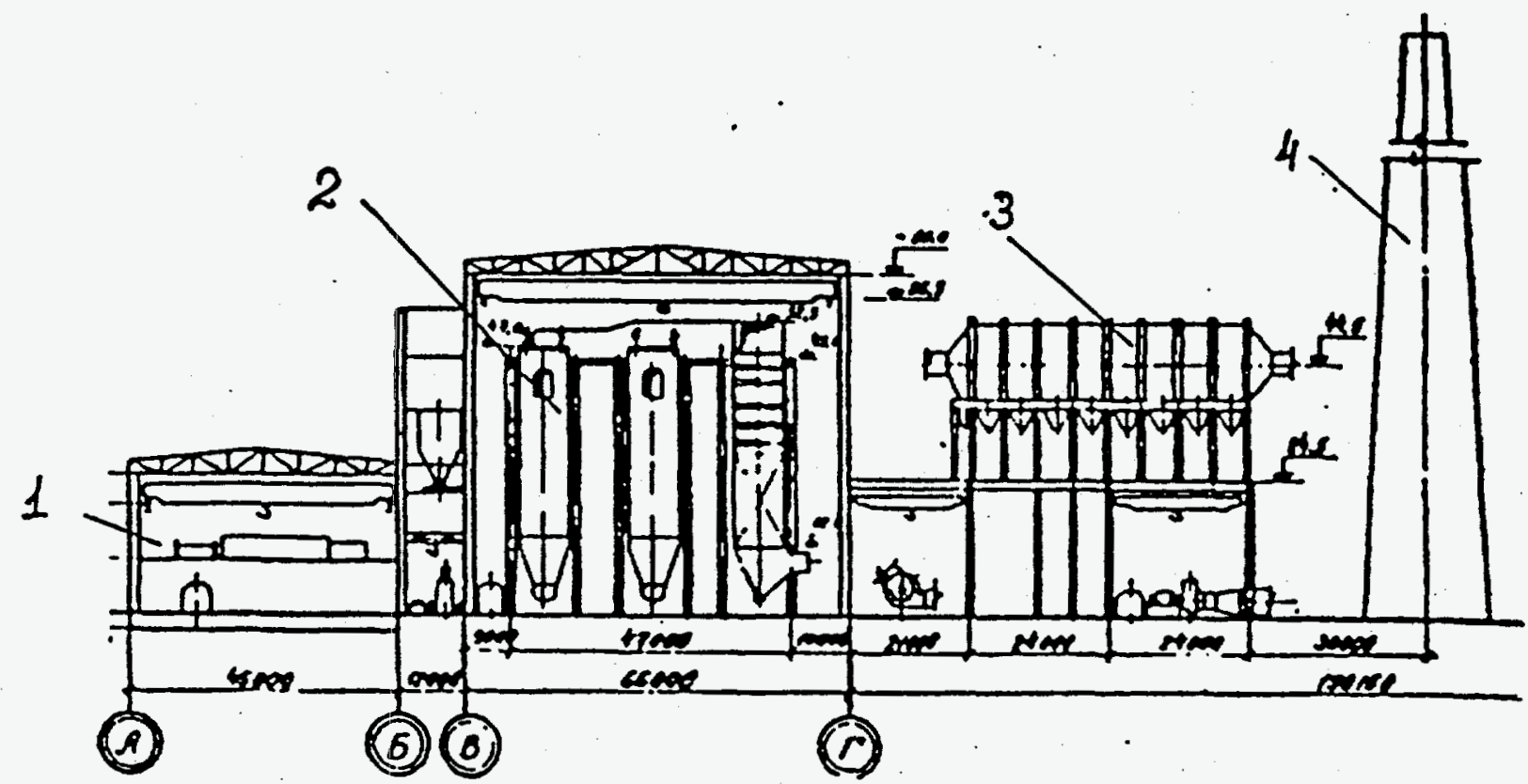

Fig. 33. Cross-section of 300 aW CFB unit 1 -ST; 2 - CFB boiler; 3 - ESP; 

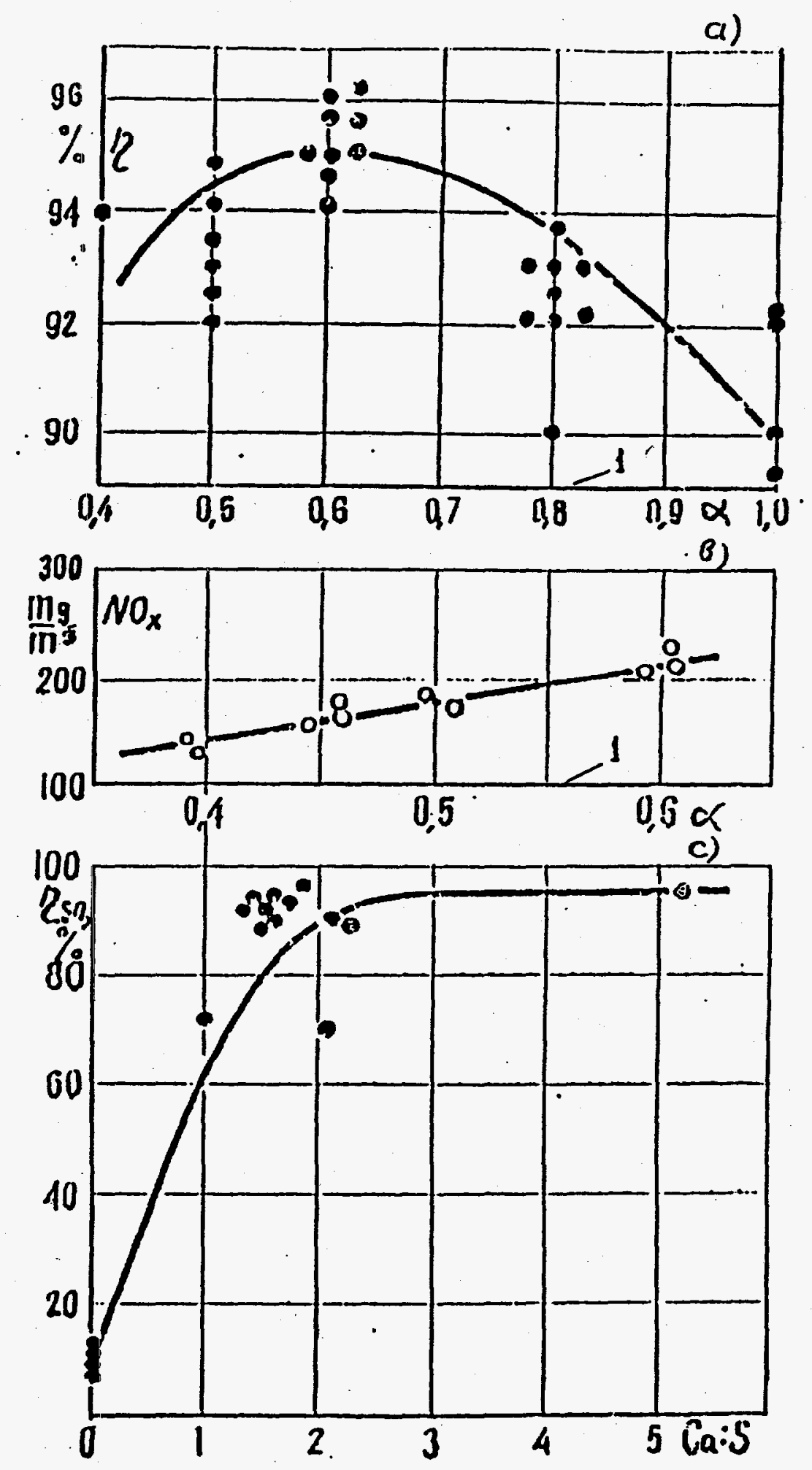

Fig. 34. Anthracite culm firing efflclency with CFB

(a) anthracite culm conversion;

(b) NOx formation ( $\mathrm{Ce} / \mathrm{S}=2.5-4.0$, $\left.t=860-900^{\circ} \mathrm{l}, \alpha=1.15-1.25\right)$; (i) $\mathrm{SO}_{2}$ fixation. 1 - primary air to fuel stoichiometry 


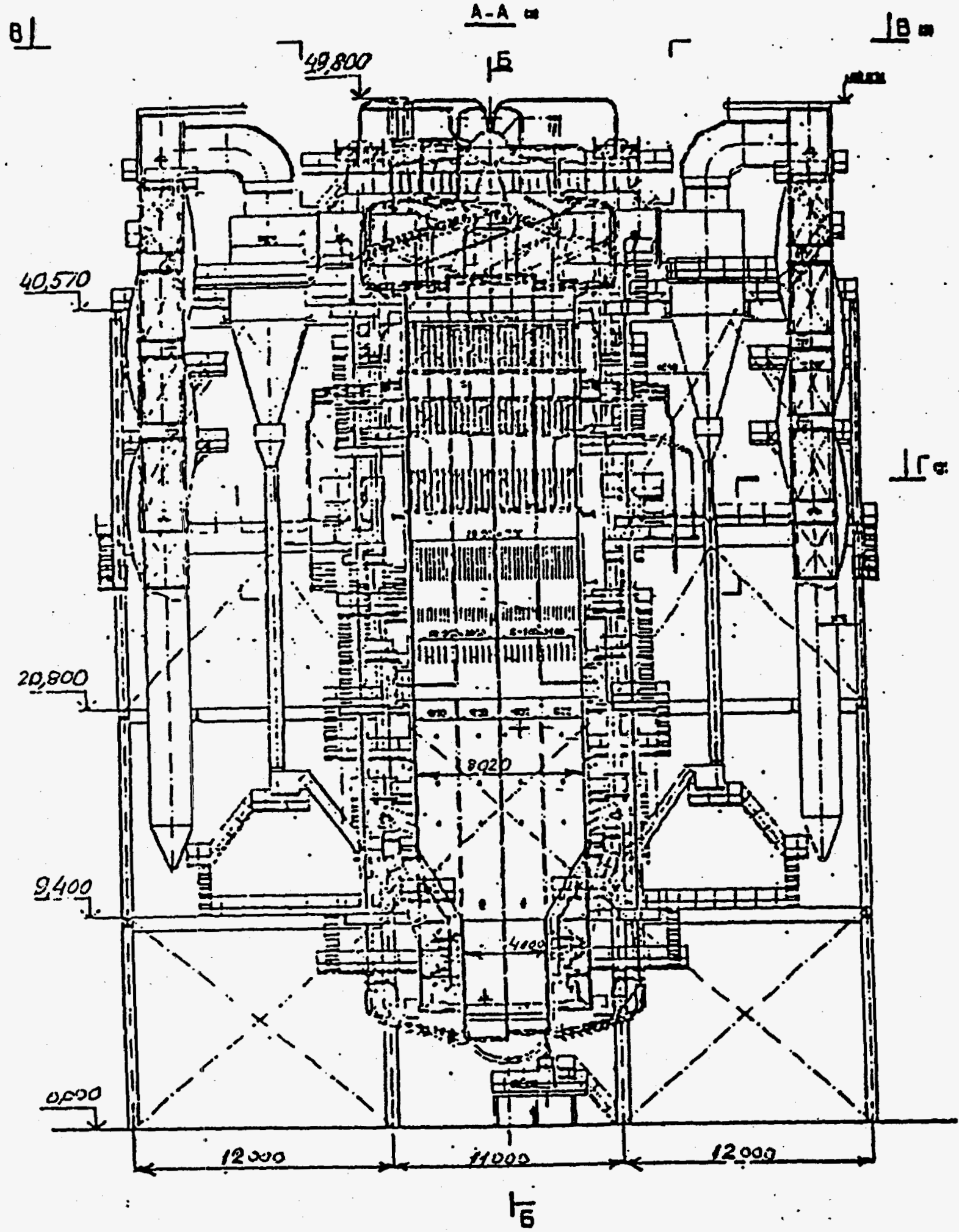

Fig.35.Deno 500t/h CFB boiler with "cold" cyclones. 


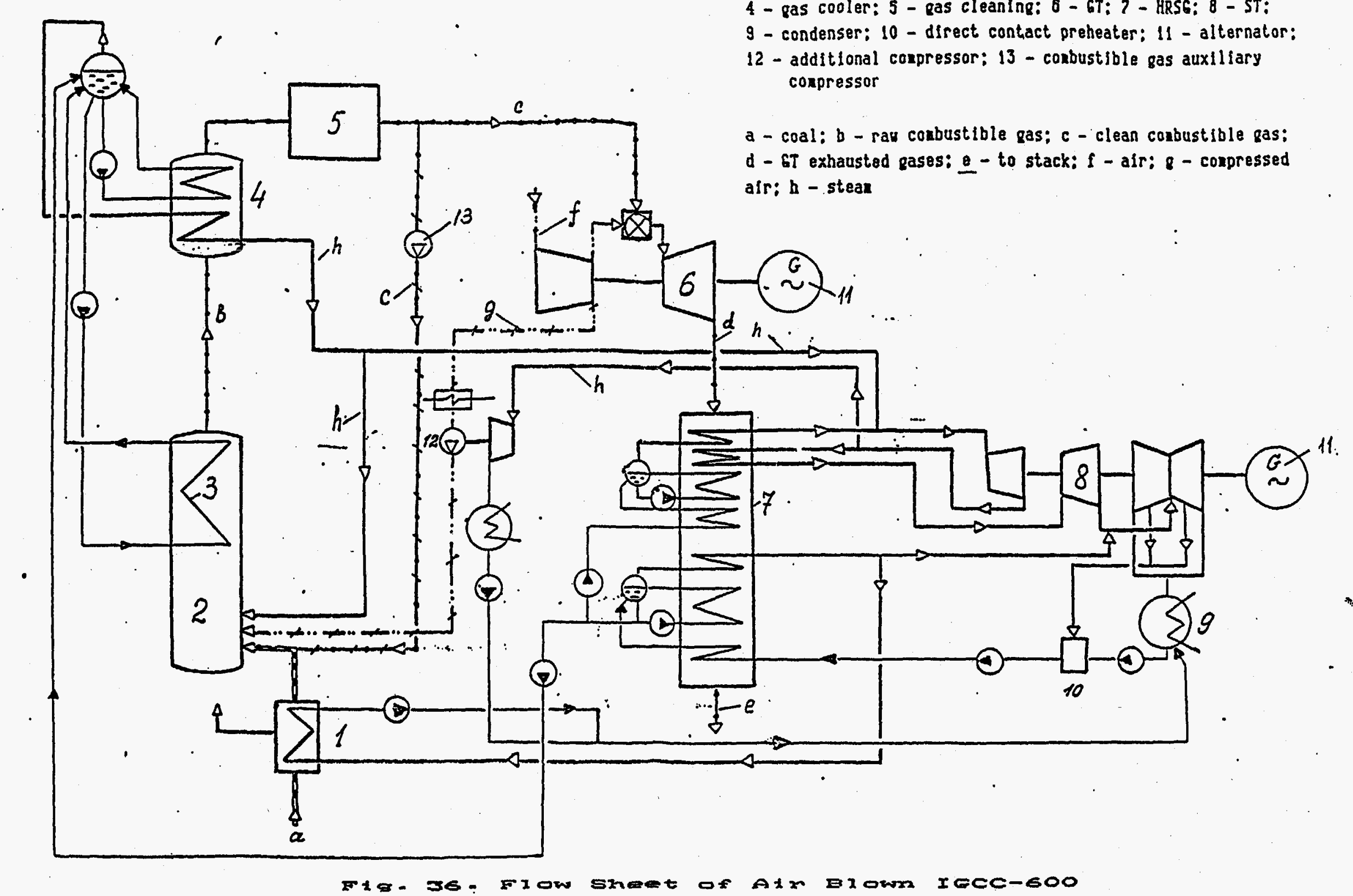

1 - coal treatuent: 2 - pasiffer: 3 - vaterwall coollng systes:

4 - gas cooler: 5 - pas cleaning: 6 - 6T: 7 - HRSG: 8 - ST:

9 - condenser; 10 - direct contact preheater: 11 - alternator:

12 - additional compressor: 13 - coubustible gas auxillary conpressor

a - coal: b - rau conbustible gas; c - clean conbustible gas: d - GT exhausted gases: 8 - to stack: $f$ - air: 8 - coupressed afr: $h$ - stean

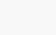




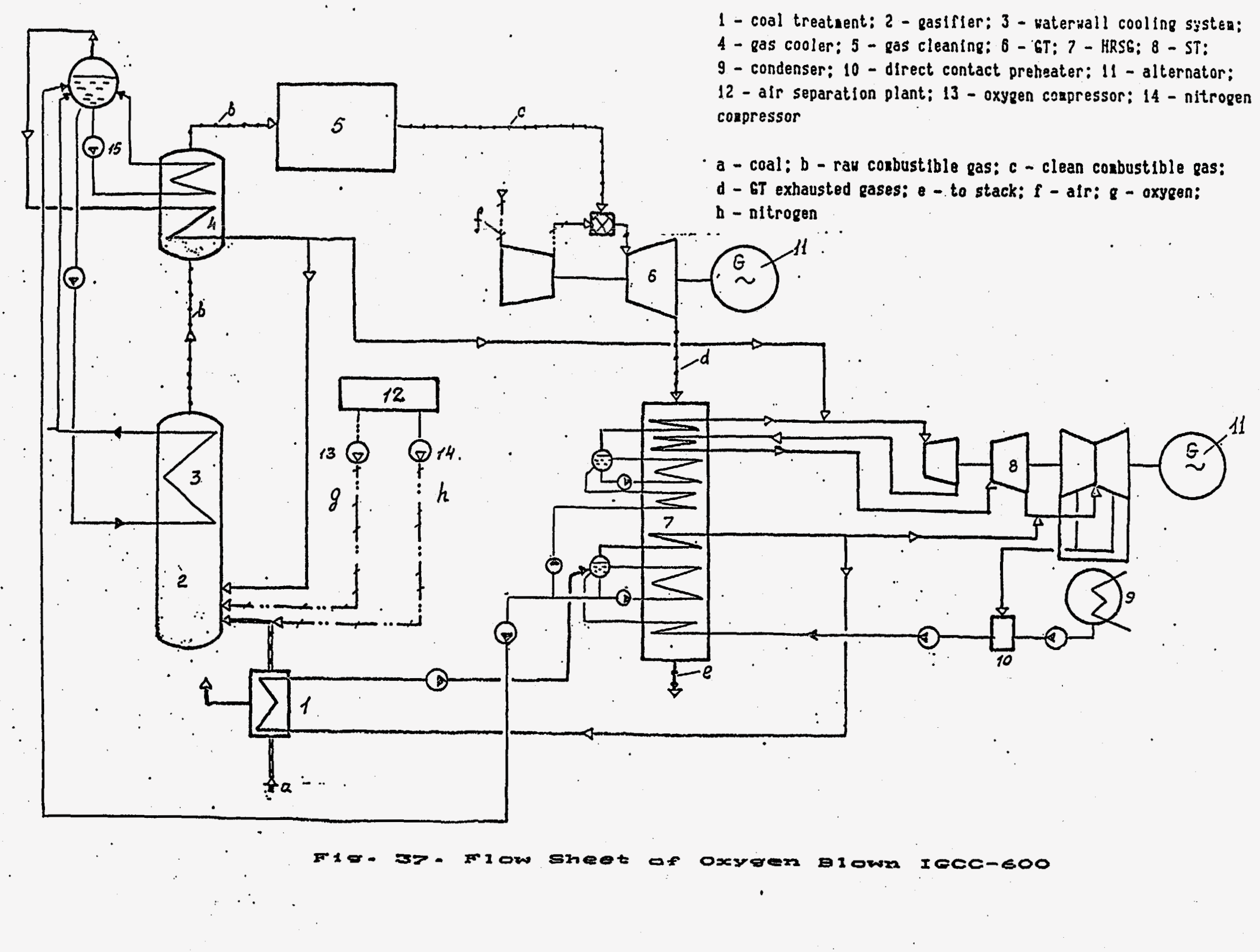




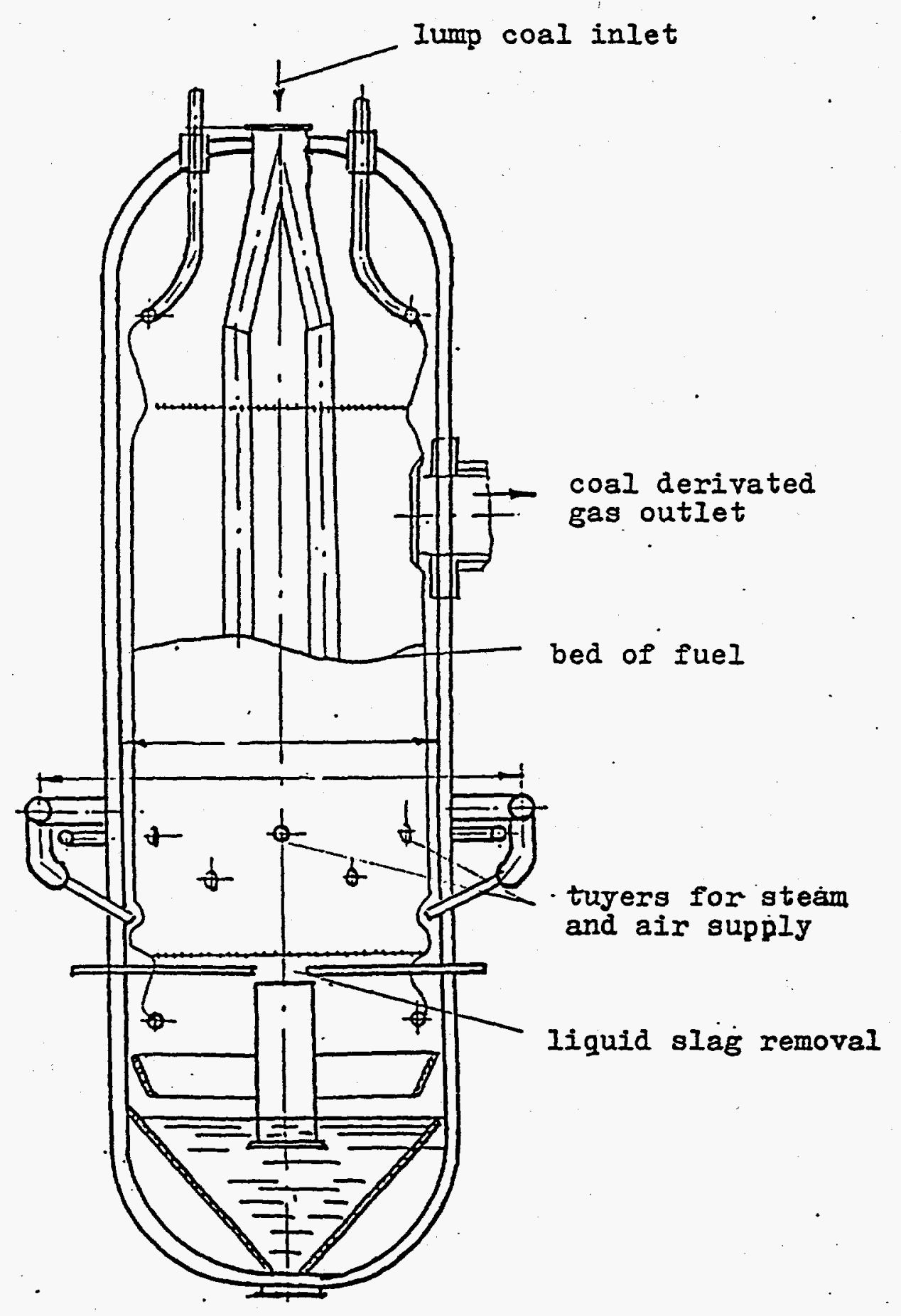

Fig. 38. Moving-bed gasilier 

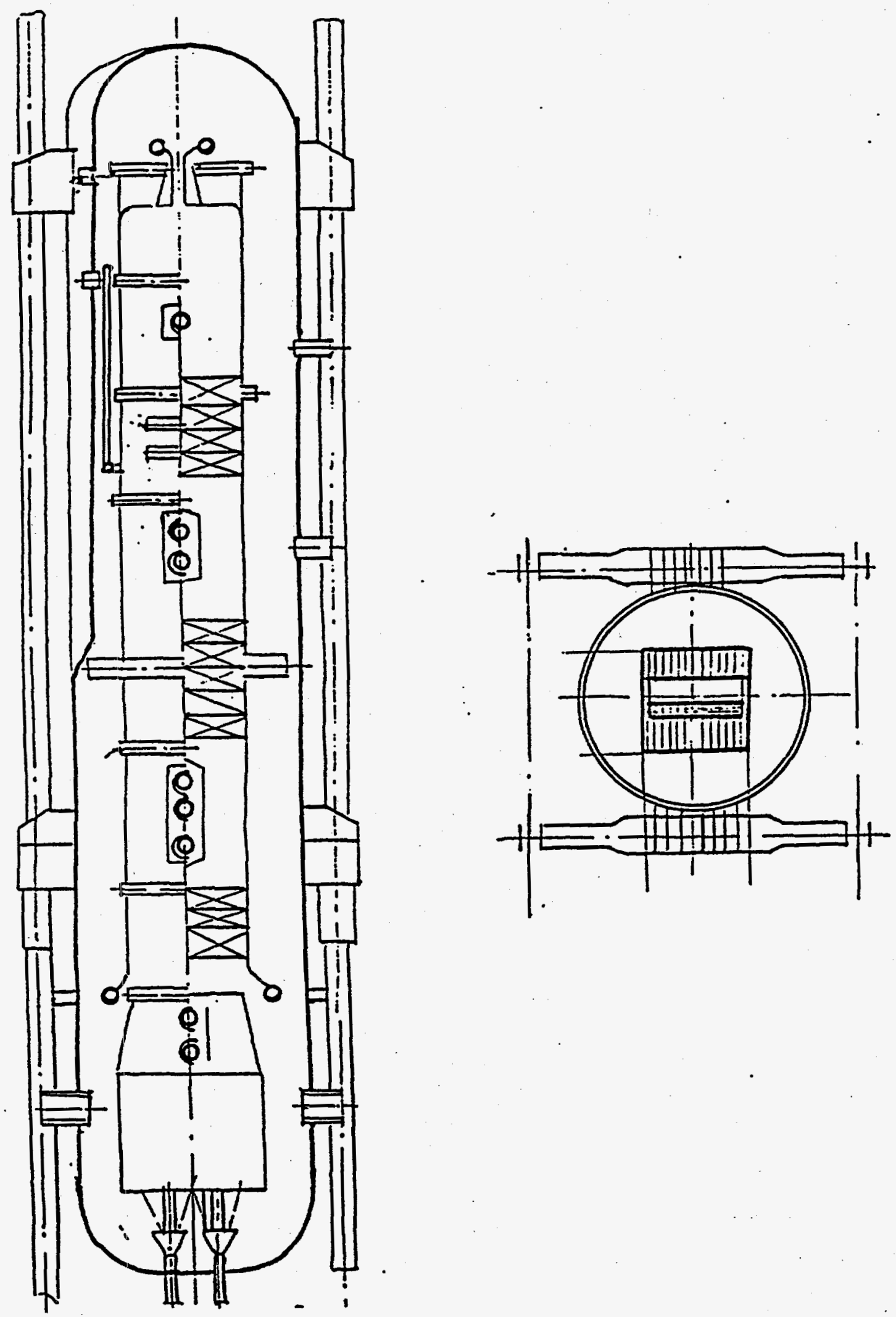

Pig. 39. Convect1ve gas cooler for moving-bed gasifier 


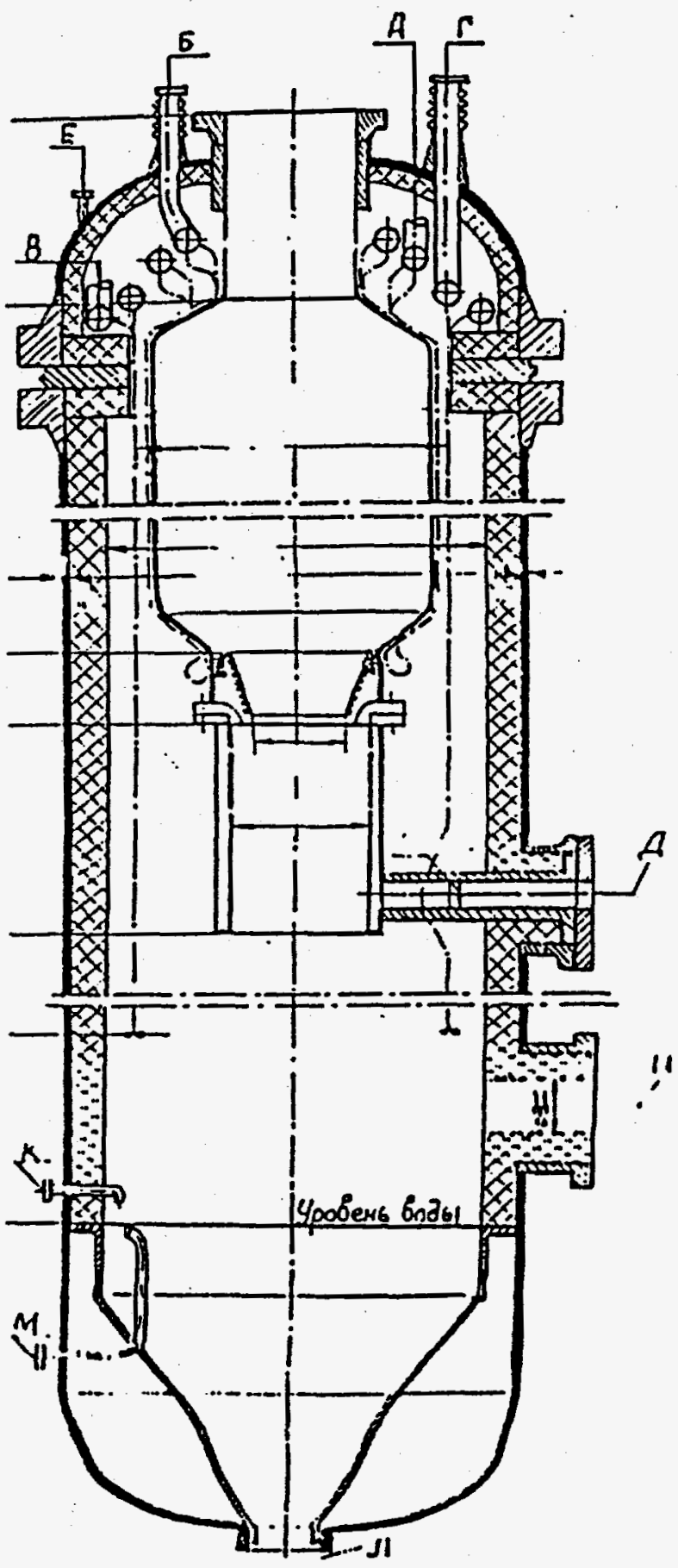

Fig. 40. Entrained-flow oxygen blown gasifier 


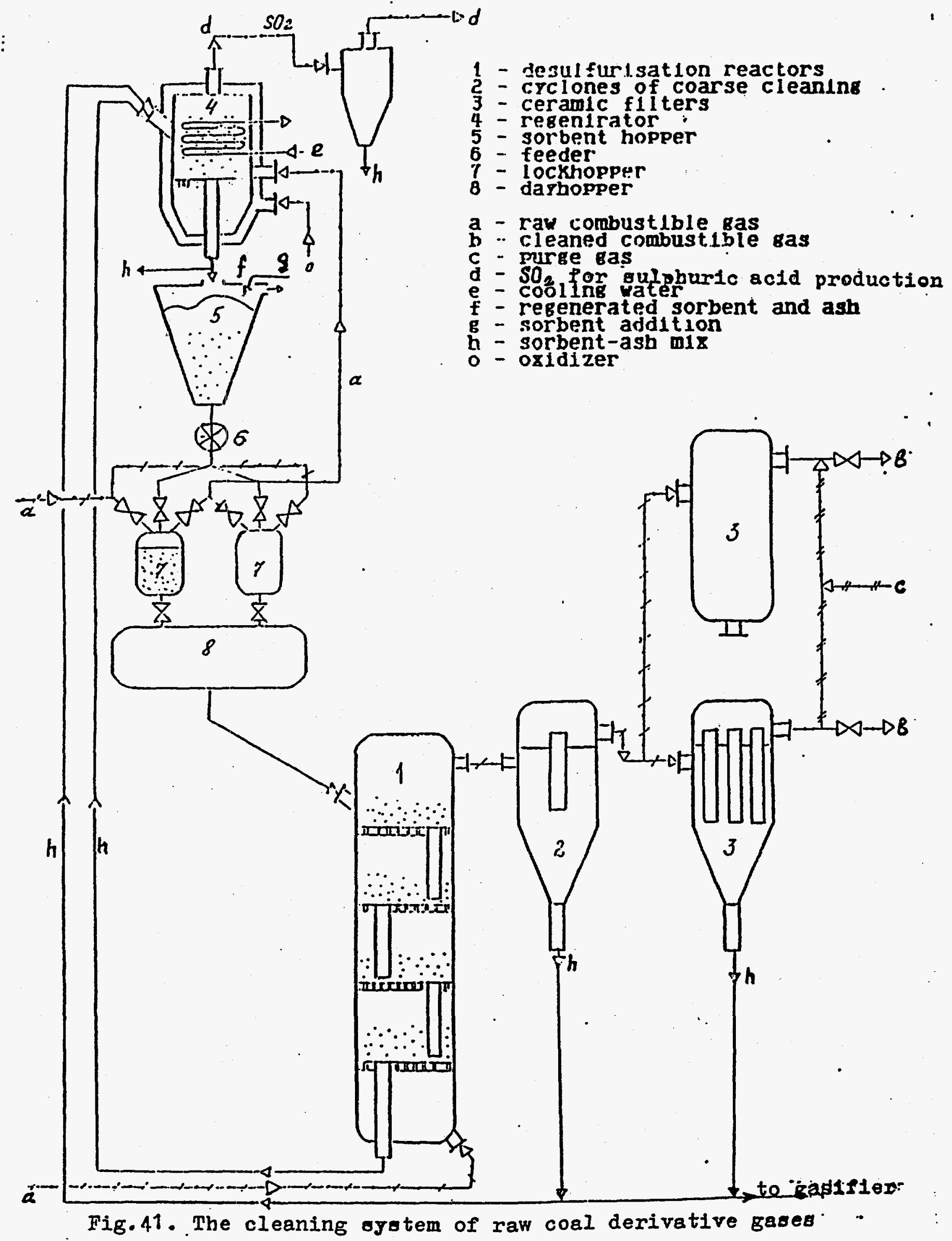


1 - GT: 2 - HRSG; 3 - ST: 1 - condenser: 5 - direct contact preheater: 6 additional conpressor: $?$ - auxillary turblne: 8 - condensate punp; 9 - feed puep: 10 - air to gasifler (for air bloun options): 11 - feeduater to gas cooler: 12 - stean for coal drying: 13 stean to gasifier: 14 - stean of gasification systex: 15 - condensate return fron dryers

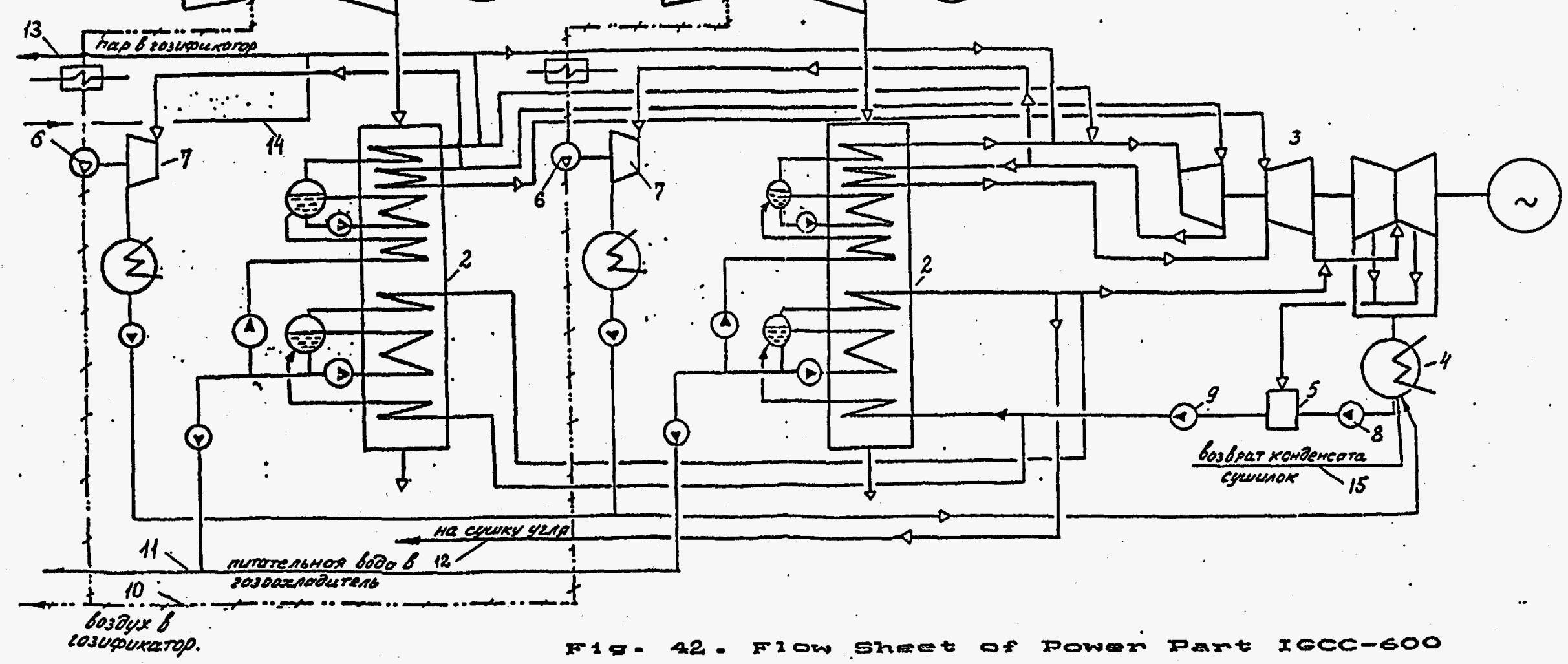




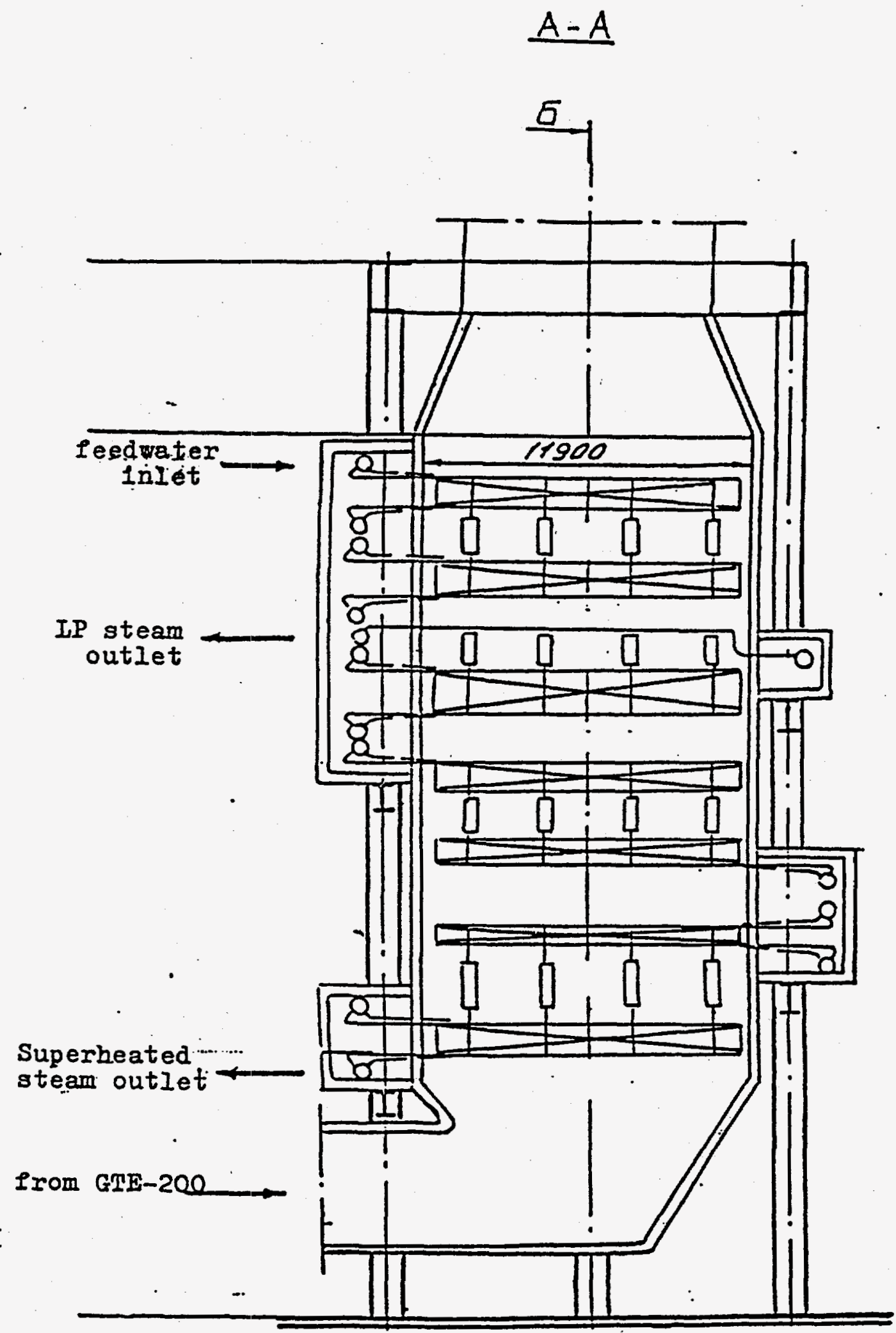

Pig. 43. Heat-Recovery Boiler 


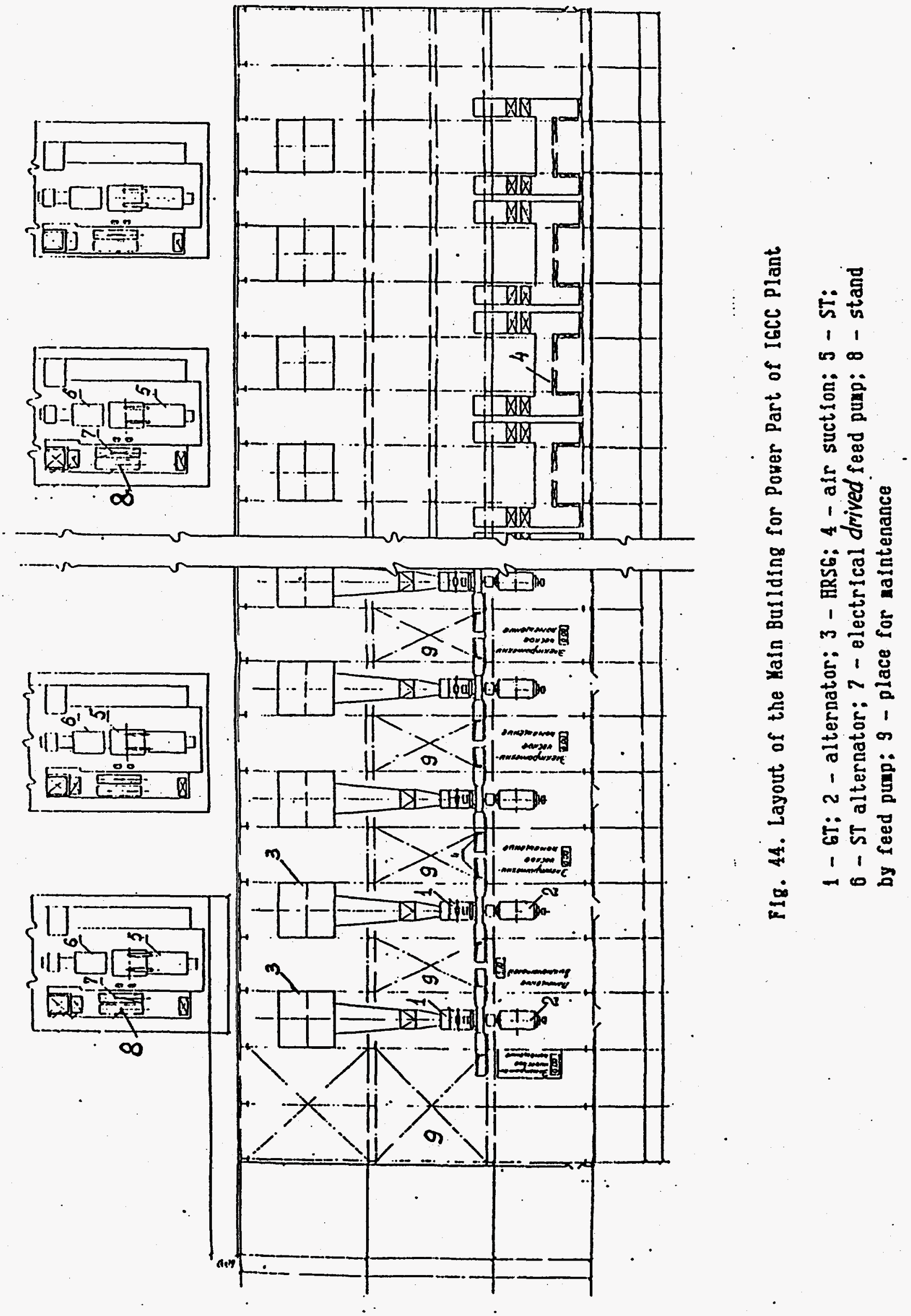




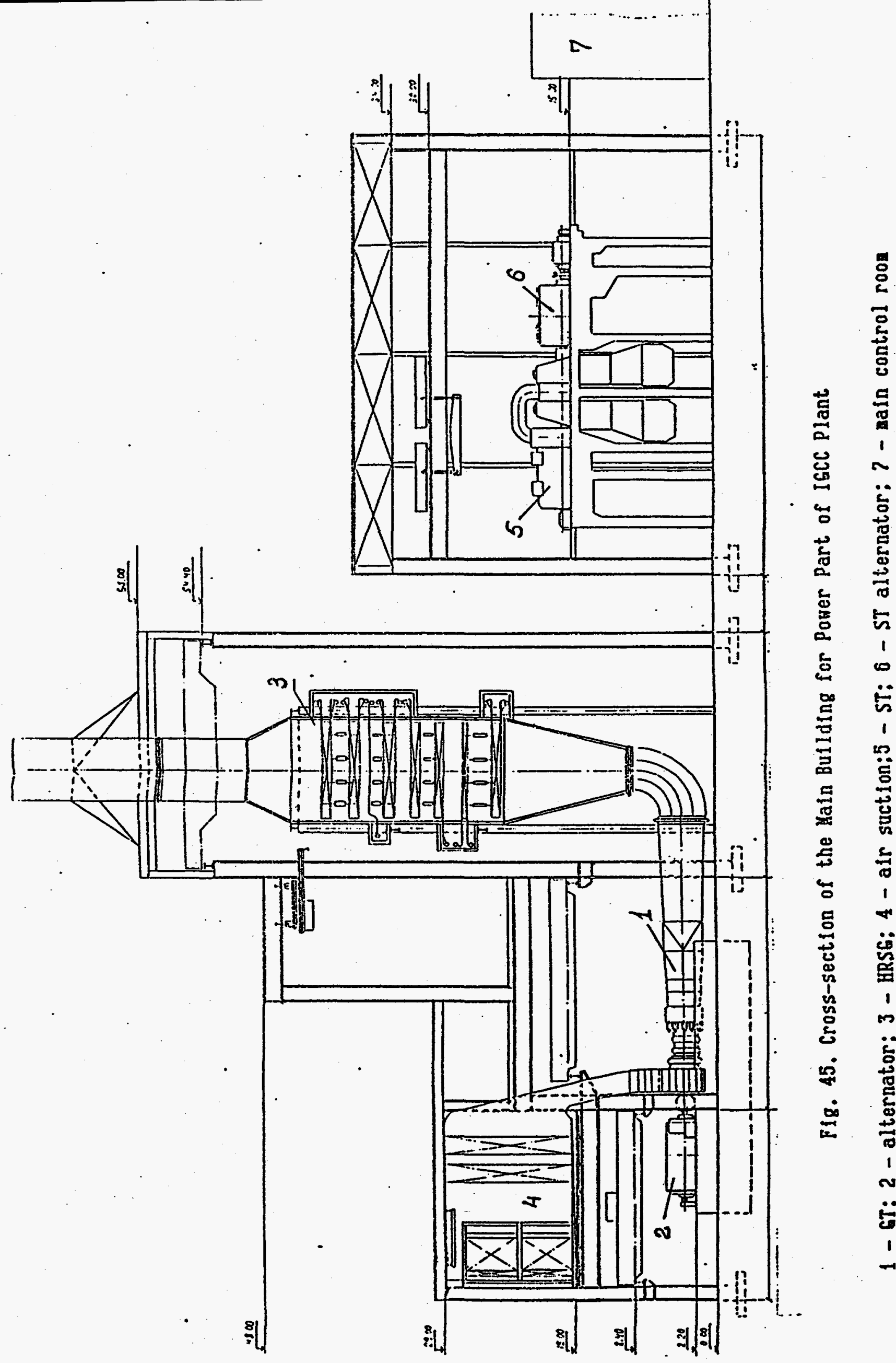




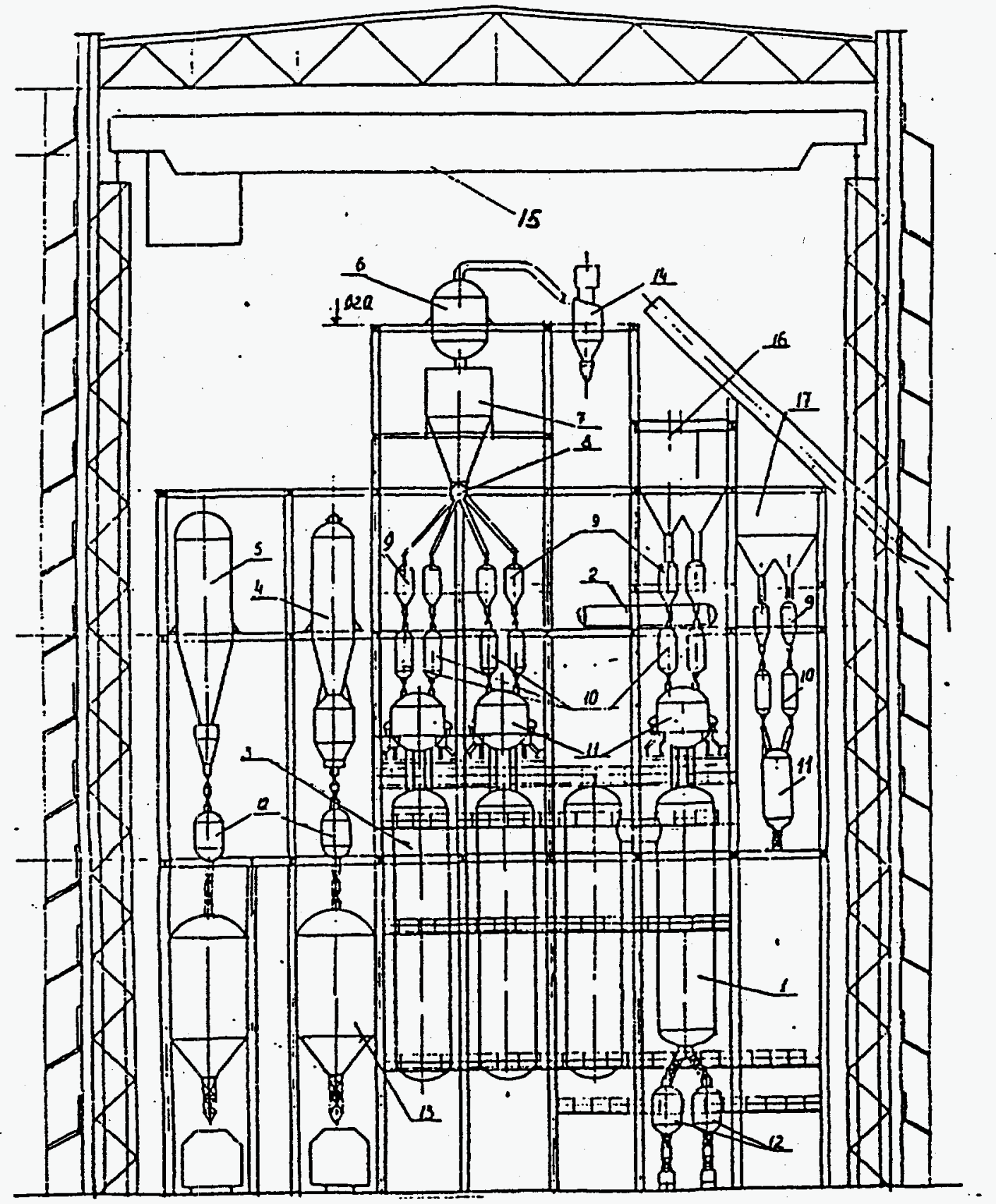

Fig. 46. Cross-section of gasification system using air bloun noving-bed gasifier

1 - gasifier: 2 - stean drun of gasifier cooling: 3.- reactor of desulfurisation systen: 4 cyclone of coarse cleaning: 5 - ceranic filters: 6 - regenerator: 7 - sorbent hopper: 8 - feeder: 9-10 - lockhopper systex: 11 - day hopper: 12 slag resoving lockhopper: 13 - hopper: 14 cyclone: 15 - bridge crane: 16 - lump coal hopper: 17 - fines hopper: 18 - convective gas cooler 


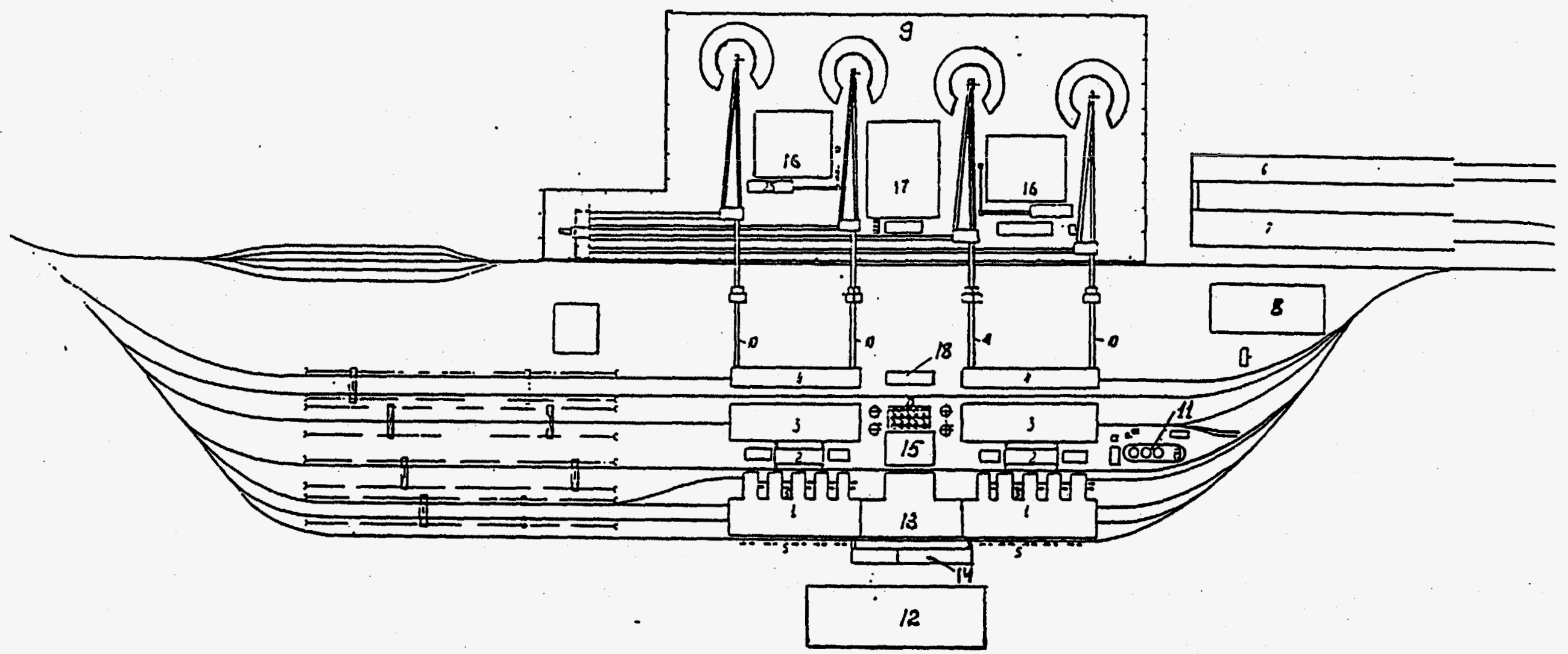

Fig. 42. The Layout of TPS with 10/IGCC $600^{\circ}$ un Units

1 - nain büilding: 2 - nain control roox: 3 - gasification systens: 4 - fuel treatment: 5 - transforners; 6 - air separation plant (ASP ): 7 - ASP coupressor's building: 8 - sulphuric acid plant: 9 - coal yard: 10 - conveyors galerles: 11 - fuel ofl tank: 12 - open suitchgear: 13 - auxillary building: 14 - officies: 15 - water treatnent: 16 - ash disposal place: 17 - sladge pond; 18 - auxilfary bollerhouse 


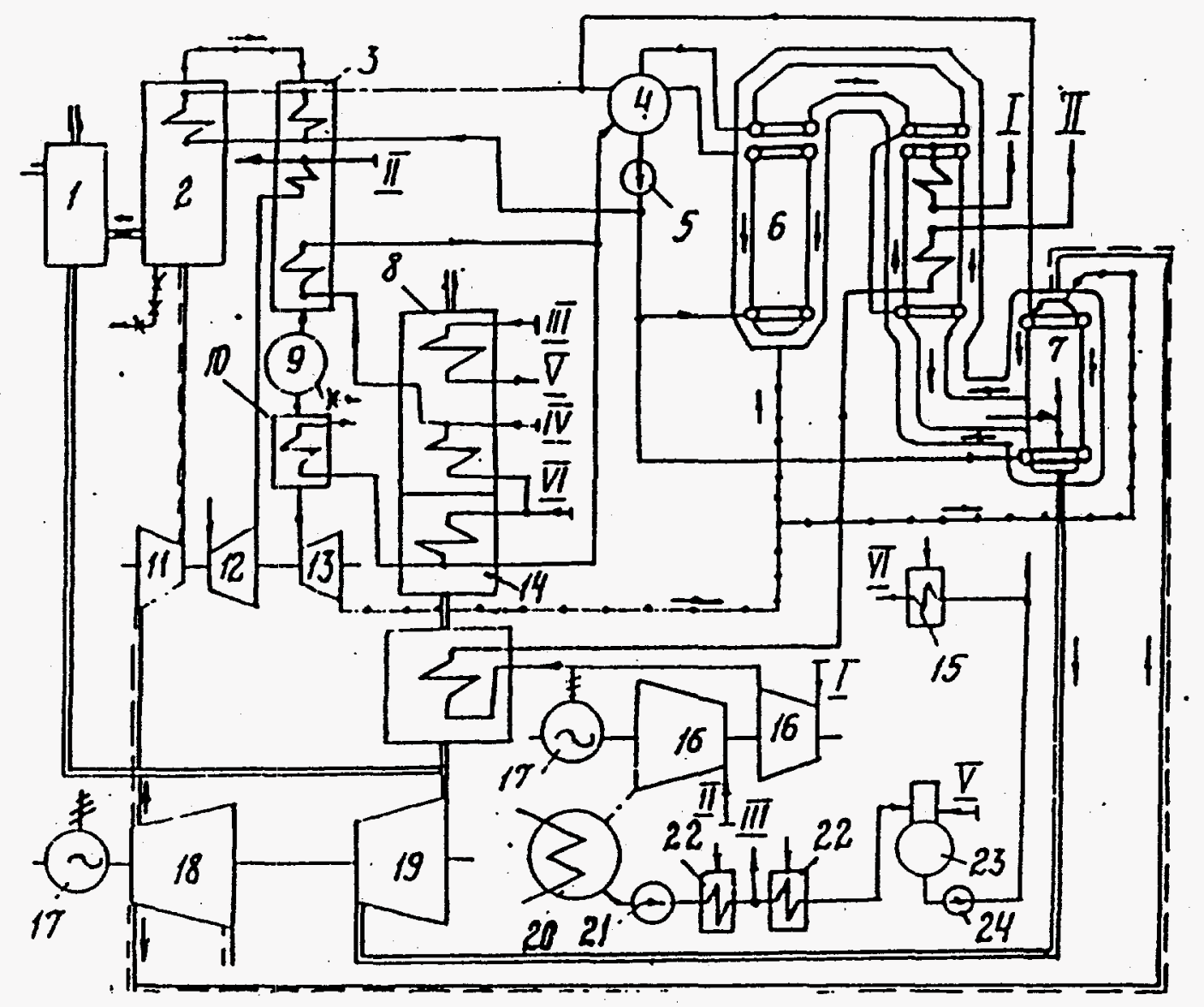

Fig. 48. Flow Sheet of IGCC Unit rated 250 MH

1 - coal drying: 2 - fluidized-bed gasifięr:

3 - gas cooler: 4 - drun of SSG: 5 - internal

circulating pump SSG: 6 - furnace of SSG: 7 - ton conbuster: 8 - gas-water heater (GHH): 9 ... scrubber: 10 .. gas heater: 11 .. additional conpressor: 12 - auxillary stean turbine: 13 - turboexpander: 14 - econonizer: 15 - HP preheaters: 16 - nain stean turbine: 17 - alternators: 18 - GT conpressor: 19 - GT turbine: 20 - stean condenser: 21 -condencate punp: 22 - LP preheaters: 23 - deaerator: 24 - feed punp: I.II - stean to HP and LP sections of ST: III - condencate to GHH: IU - feeduater to GHH: U - condencate to deaerator: UI - feeduater ${ }^{\circ}$. to econonizer 


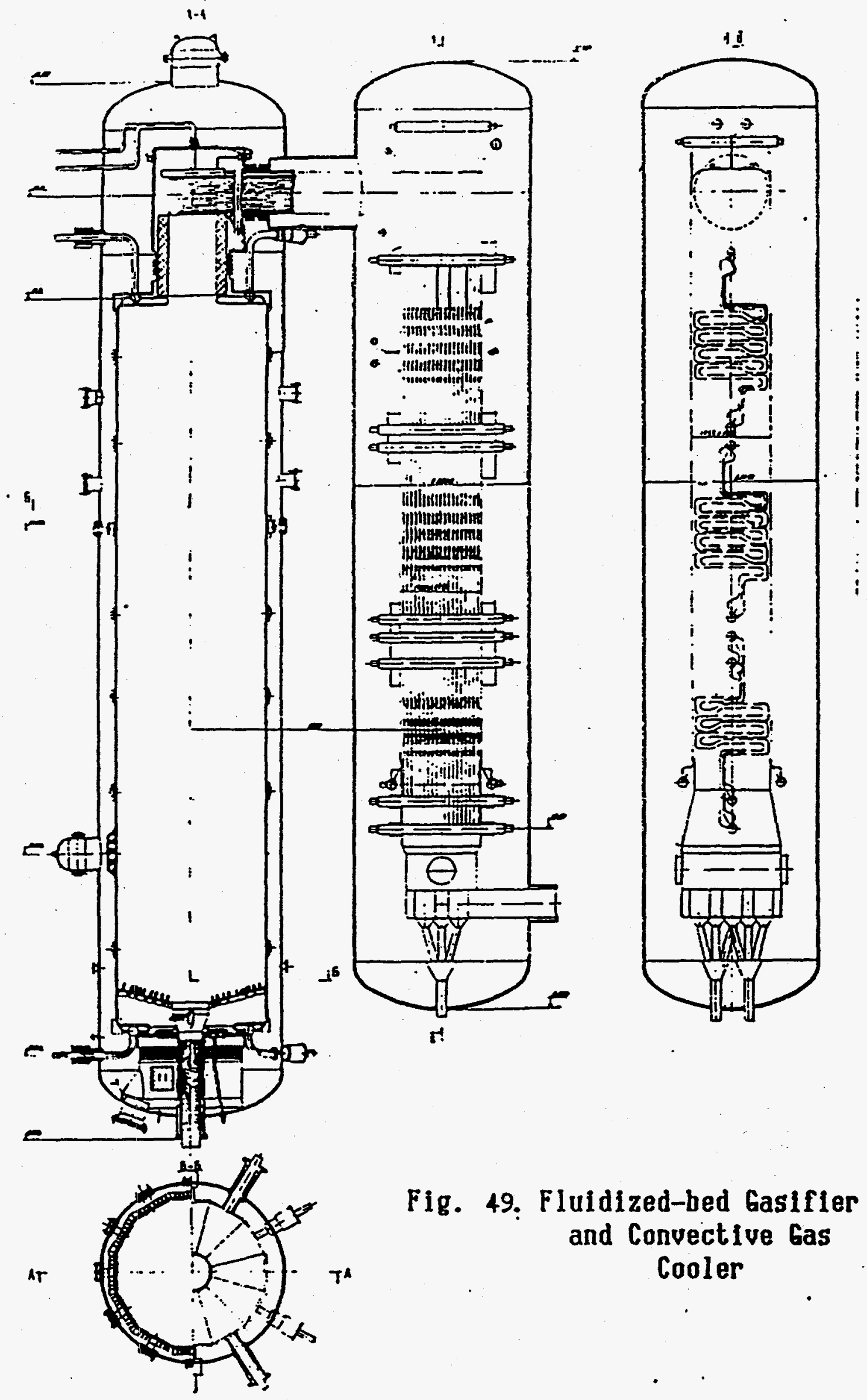




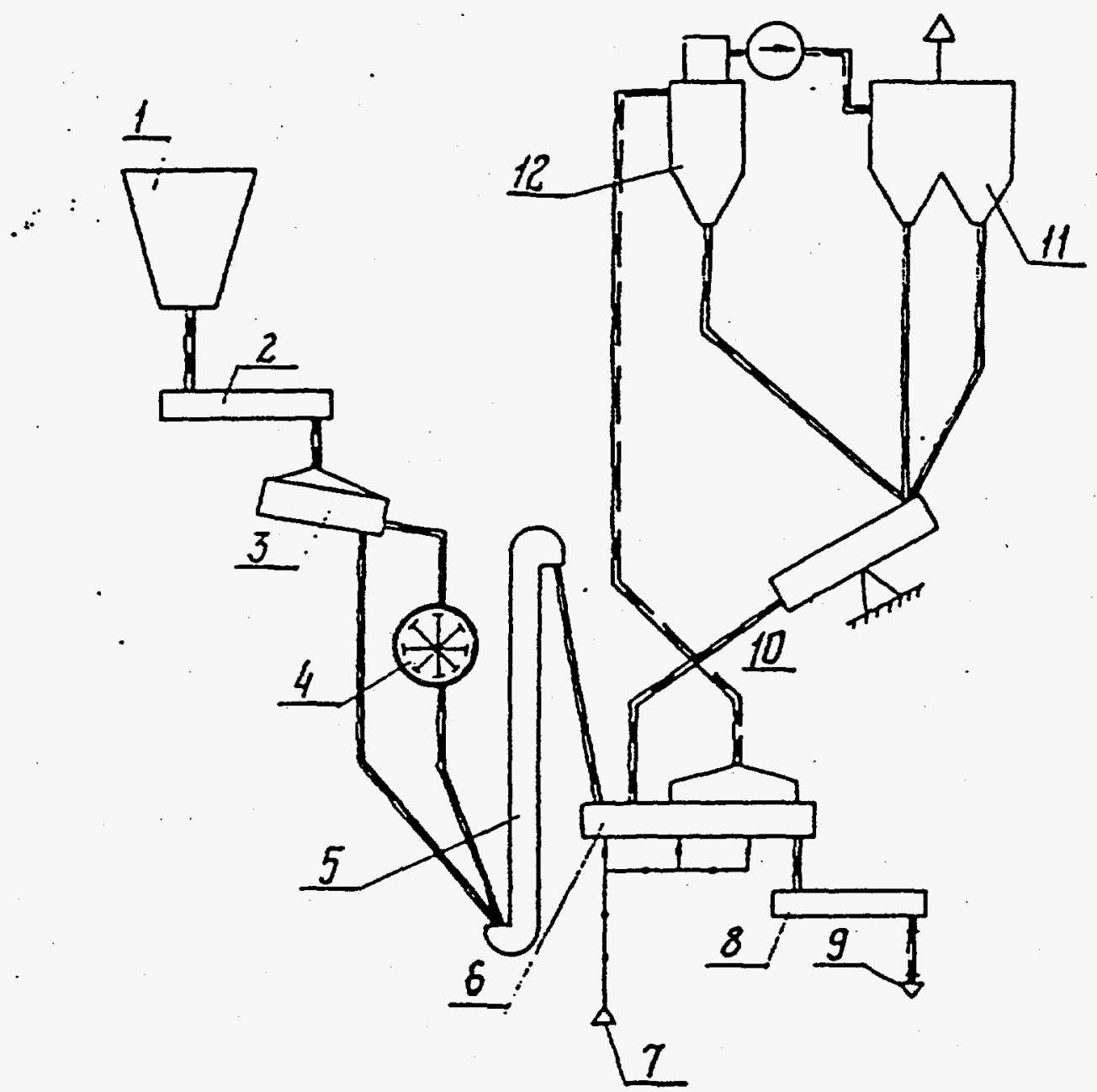

Fig. 50. Fuel Treatment for Fluidized-bed Gasifier

1 - raw coal hopper: 2 - feeder: 3 - screen

4 - crusher: 5 - elevator: 6 - fluidized-hed dryer: .

7 - conbustion gases: 8 - treated fuel feeder:

9 - to lockhopper: 10 - dust granulator: 11 - ESP:

12 - cyclone 


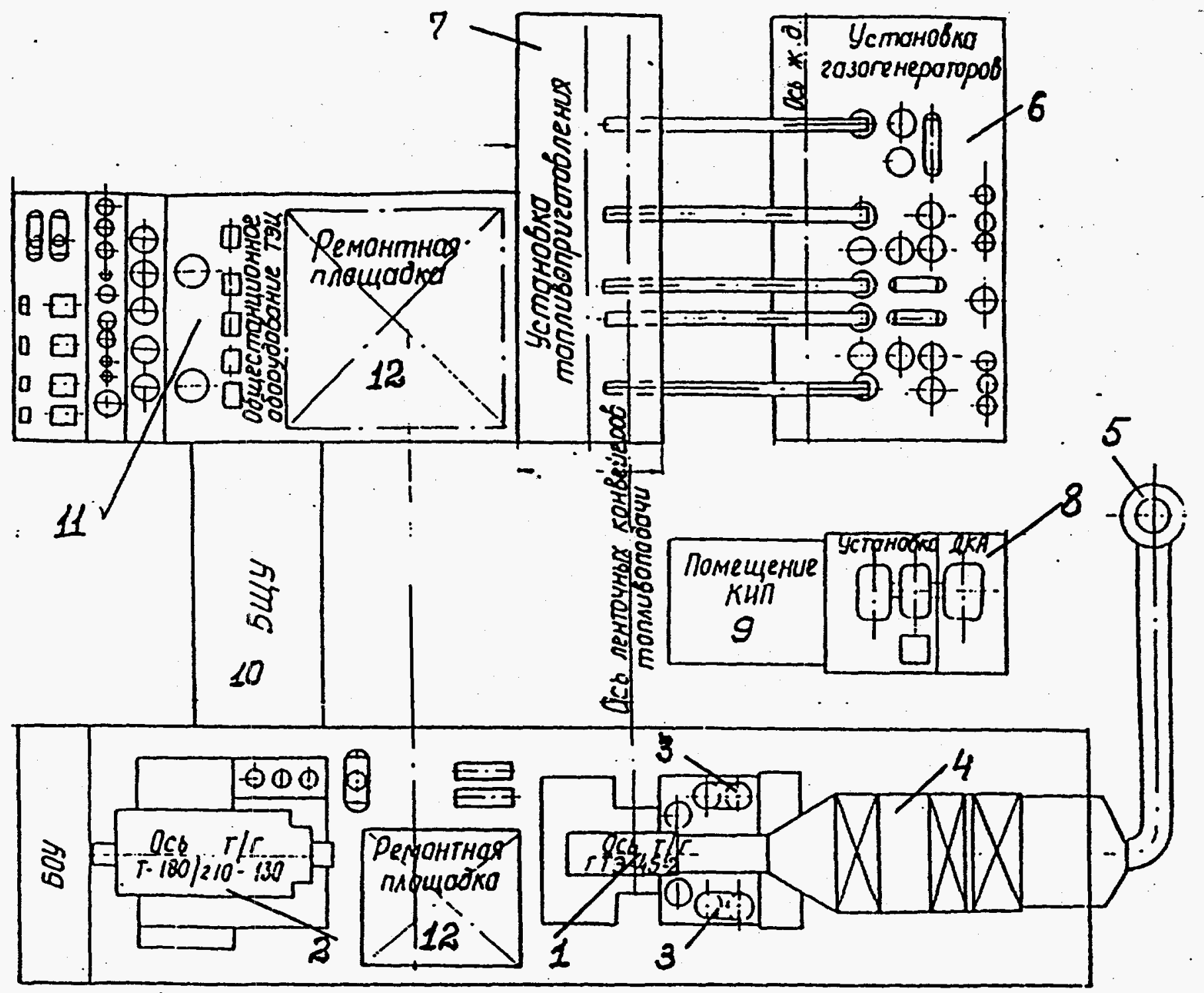

Fig. 51. The Layout of IGCC Plant rated 250 IK

1 - GT: 2 - ST; 3 - supercharged boiler: 4 - gas- water heat exchanger: 5 - stack; 6 - gasifier's building: 7 - fuel treatment; 8 - auxiliary compressor-turbodetander: 9 - I8C roox; 10 - wain control roox: 11 - balance of plant equipnent; 12 - place for vaintenance 